Portland State University

PDXScholar

$1-1-1983$

\title{
External dependence and national urban development policy: a structural analysis of graduate unemployment in Nairobi, Kenya
}

Fantu Cheru

Portland State University

Follow this and additional works at: https://pdxscholar.library.pdx.edu/open_access_etds Let us know how access to this document benefits you.

Recommended Citation

Cheru, Fantu, "External dependence and national urban development policy: a structural analysis of graduate unemployment in Nairobi, Kenya" (1983). Dissertations and Theses. Paper 779.

https://doi.org/10.15760/etd.779

This Dissertation is brought to you for free and open access. It has been accepted for inclusion in Dissertations and Theses by an authorized administrator of PDXScholar. Please contact us if we can make this document more accessible: pdxscholar@pdx.edu. 
EXTERNAL DEPENDENCE AND NATIONAL URBAN DEVELOPMENT POLICY:

A STRUCTURAL ANALYSIS OF GRADUATE UNEMPLOYMENT

IN NAIROBI, KENYA

by

FANTU CHERU

A dissertation submitted in partial fulfillment of the requirements for the degree of

DOCTOR OF PHILOSOPHY

in

URBAN STUDIES

Portland State University

(C) 1983 Fantu Cheru 
TO THE OFFICE OF GRADUATE STUDIES AND RESEARCH:

The members of the Committee approve the dissertation of Fantu Cheru presented May 3, 1983.

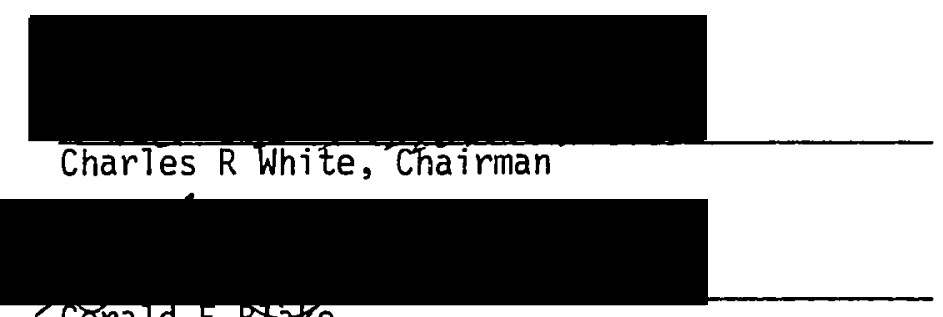

Gerald F Btake



Jerry W Lansdowne



APPROVED:

Nohad A Foutan, Dean, Urkan and Public Affairs

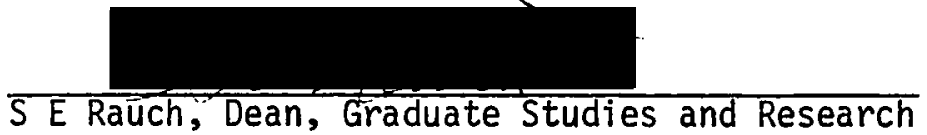


AN ABSTRACT OF THE DISSERTATION OF Fantu Cheru for the Doctor of Philosophy in Urban Studies presented May 3, 1983.

Title: External Dependence and National Urban Development Policy: A Structural Analysis of Graduate Unemployment in Nairobi, Kenya.

APPROVED BY MEMBERS OF THE DISSERTATION COMMITTEE:

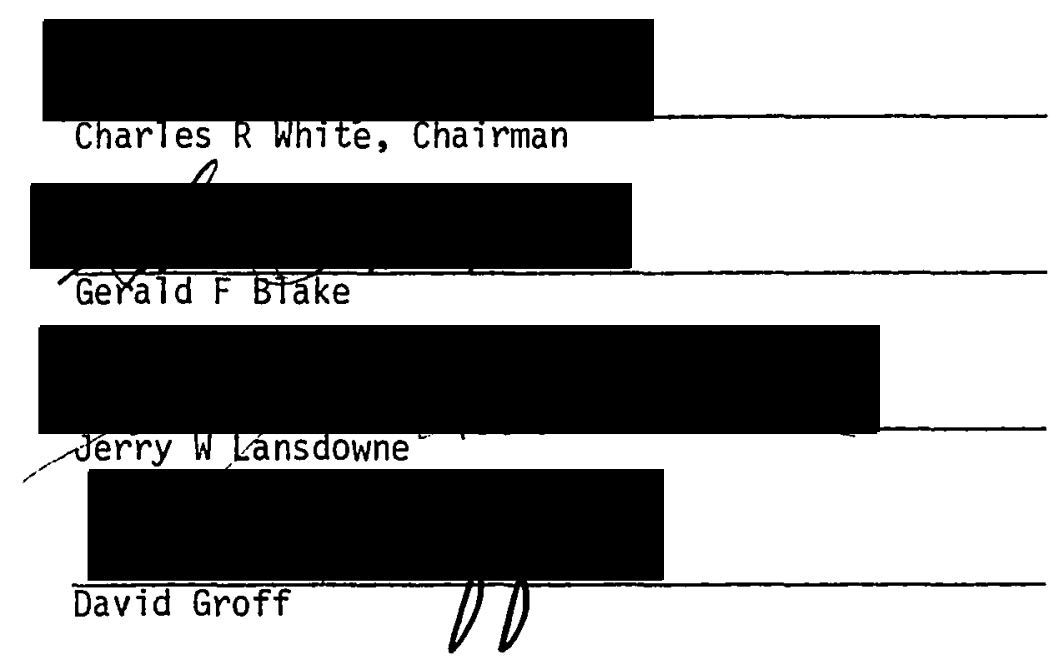

This study examines the attempts by the government of Kenya to develop and implement policies directed toward the problem of urban unemployment. Specifically, it focuses upon two policy areas directly related to urban unemployment: education and economic growth. An additional element of this study is to examine the possible consequences 
of Kenya's external dependency upon the linkages among education, economic growth, and employment opportunities.

Throughout the 1960's, the main problem in the educational sector of developing societies as perceived by planners, politicians, and theorists, related primarily to the challenge of producing numbers of educated people to promote a rapid localization of jobs and to sustain the high rate of economic growth which were believed necessary for development. The policy prescriptions involved a dramatic quantitative expansion of school enrollments. This was understandable and inevitable in view of the dramatic manpower shortages which existed at the time of independence.

In recent years, however, these efforts at expanding educationa? opportunities for the people of Kenya have resulted in widespread unemployment of school graduates. The dynamic rate of economic growth and a forceful campaign of Kenyanization have not been successful in creating sufficient employment to meet the growing numbers of Kenyan students who believe themselves qualified for gainful employment. The problem is particularly significant in the city of Nairobi, where the African population is increasing through births and migration by over $10 \%$ per year. In contrast, the tiny increase in employment is scarcely noticed.

In an attempt to resolve the problem of unemployment among graduates, governmental policies in Kenya were directed toward improving various components of the school system, such as examination content and procedures, curriculum, and vocational and technical education. Policymakers believed that the mismatch between education and employment 
was the cause of graduates lacking marketable skills to secure the needed employment. However, the impact of these educational stratagies in solving the unemployment problem has been extremely limited. Thus, any attempt to trace the causes of graduate unemployment in Kenya rapidly leads to an analysis of the entire socio-economic structure and touches on almost every element of development stratagies. A major factor is Kenya's dependency on external economic forces, which influence and constrain its actions by controlling the amount of resources available to it and the distribution of political power. The evidence presented in this study points to the continued vulnerability and limitations of the Kenyan economy imposed by its periphery role within the world economic system.

While changes in curriculum and in the examination system may be expected to bring educational benefits, it is unrealistic to suppose that such changes alone will improve the employment prospects of graduates in the labor market. The results of this study suggest that the roots of the unemployment problem are in the structure of society, and particularly in the failure of the Kenyan economy to industrialize and modernize at a rate that absorbs the labor force. These economic problems are traced to Kenya's continued dependency on external economic assistance, which reduces its ability to determine the course of national development independently. This economic problem is of such a magnitude that it can only be solved by structural adjustments, both internaliy and externally. 


\section{ACKNOWLEDGEMENTS}

I wish to express my sincere thanks to the government of the Republic of Kenya for granting me a research clearance to conduct this study and for the vital cooperation of the various governmental officials during the data collection process. I wish also to acknowledge the special assistance provided by the Director and staff of the Institute for Development Studies of the University of Nairobi.

Similarly, I wish to acknowledge the assistance of my dissertation committee members over the past two years. Special mention must be made of Professor Charles $R$ White, who has been my principal mentor and advisor since 1976 and who played a key role in my decision to do graduate work. In terms of financial support, I am very grateful to the Maurie Clark Foundation for the generous grant which enabled me to spend six months in Kenya. I also wish to express my special thanks to my good friend and companion, Dr Patricia $J$ Rumer, for sharing with me the trials and triumphs of graduate education over the past four years.

Finally, this dissertation is dedicated to my parents, who never had the opportunity to learn how to read and write, but who remain consistent advocates of the importance of education for liberation. 
ACKNOWLEDGEMENTS .................. ... $i_{i}$

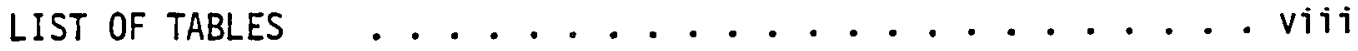

LIST OF FIGURES . . . . . . . . . . . . . . . . . xiji

CHAPTER

I INTRODUCTION ANID REVIEW OF THE LITERATURE . . . . . . 1

The Problem ............... . . 2

Literature Review . . . . . . . . . . 3

The Diffusionist Perspective and the National Development Experience in Africa

Education and Development: The Human Capital Approach

A Critique of Diffusion and Human Capital Theories

Alternative Explanations: Dependency and "Revised Dependency"

Relevance of Dependency Analysis for Africa and Kenya

"Revised" Dependency Analysis: the New "Orthodoxy"

Educational Research and the Dependence Perspective

Research Design and Methodology ........ . 31

Methodologic al Techniques

Analysis of Data 
Summary . . . . . . . . . . . 33

II THE DEVELOPMENT OF WESTERN EDUCATION IN KENYA,

1846-1980: A CASE OF DEPENDENCY RELATIONSHIP . . . 35

The Struggle for Political Control . . . . . 35

Colonialism and Economic Change

Educational Policy in Colonial Kenya

Educational Policy After 1925

Educational Policy After World War II

African Reaction to Colonial Restrictions

Summary

Reaping the Fruit of "Uhuru" . . . . . . . 59

Educational Policy in Post-Independent

Kenya, 1963-1980

The Distribution to Educational Resources

Since Independence

The Harambee School as a Shadow System of Education

Summary

III KENYA'S ECONOMIC DEVELOPMENT IN PERSPECTIVE: PITFALLS

IN PAST AND PRESENT DEVELOPMENT POLICIES . . . . . 86

Priorities in Development Policy . . . . . 87

The Structure and Performance of the Kenyan

Economy Since Independence in 1963 ...... . 89

Foreign Investment and Governmental Policy

Economic Impact of the Employment Problem

International Trade .......... 129

Exports

Imports

Balance of Payments 
Foreign Aid . . . . . . . . . . . 138

State Entrepreneurship as an Approach to

National Control of the Economy ....... . 144

The Industrial and Commercial Development

Corporation (ICDC) and the Policy Environment . . 147

Summary ............... 156

IV GRADUATE UNEMPLOYMENT: A KENYAN DEVELOPMENT 158 PROBLEM

The School Leaver Problem in Perspective . . . 159

The Structure of Kenyan Education . . . . . 166

Primary Education

Secondary Education

Examination and Selection Process

Population Growth, Education, and Migration . . 184

Educational Strategies for Improving Urban

Employment: The Kenyan Experience . . . . 193

The Scope of Industrial Training in Kenya 198

The Village Polytechnics

Technical Training for Secondary School Leavers

Government Intervention in the Labor Market . . 215

Employment Creation by Tripartite Agreement . . . 219

The 1964 Tripartite Agreement

The 1970 Tripartite Agreement

The 1979 Tripartite Agreement

Summary . . . . . . . . . . . . 228 
$\checkmark$ ANALYSIS AND CONCLUSIONS ........... 231

The Colonial Legacy and the Ideology of Development............. 232

"Reform" or Revolution?--The Independence Bargain 233

Dependence, Transformation, and Stagnation . . 236

Continuity and Change in Educational Policy . . . 239

The Problem of Equity

Recruitment

The Education-Employment Dilemma: Concluding

Remarks . . . . . . . . . . . . 244

REFERENCES . . . . . . . . . . . . . . . . 247

APPENDICES ........................ 261 


\section{LIST OF TABLES}

TABLE

PAGE

I Allocation of Colonial Revenue on Education for the Different Races, 1926-1949 in L's.......

II Local Native Councils Education Expenditure: In Shillings 1926-1931............... 50

II Wastage and Retention in Kenyan Schools, $1963 . . .53$

IV Primary School Enrollment by Racial Groups 1963 . . 60

$\checkmark$ Approved Government Expenditure (Net) on Education As a Percentage of Tote 1 Government Expenditure, 1963/64 to 1976/77, in KL Millions ......

VI Ministry of Education Estimates of Recurrent Expenditure $1978 / 79 \mathrm{KL}^{\prime} 000^{\circ}$.......... 64

VII Primary School Enrollment 1965-78 as a Percentage of the Projected School Age Population (6-13) . .

VIII The Proportion of School Age Children (6-13) Enrolled in Primary School by District, 1971 and 1975 ..................

IX Percentage of Qualified Primary School Teachers in Each Province, for Selected Years . . . . . . 71

$X$ Per Capita Development Expenditure on Secondary Education by Province 1974-78 (KL) . . . . . 75

XI Regional Distribution of Secondary Schools, 1977 . 77 
XII Distribution of Qualified Secondary School Teachers by Province and Citizenship, 1977 . . . . . . 79

XIII Percentage of Contribution of the Semimonetary Sector to GDP, 1964-79........... 90

XIV GDP by Source, at Constant Prices 1964 . . . . . 92

XV Annual Average Rate of Growth of GDP, at 1972 Constant Prices .............. . 93

XVI Inflow and Outflow of Capital (KL '000) ..... 101

XVII Subsidiary Request for Import Protection . . . . 106

XVIII Summary of Foreign Ownership in Large Scale Manufacturing and Tourist Firms, 1966-76 .... . 110

XIX Distribution of Parastatal Involvement by Ownership 112

XX Summary of Import Dependence of Kenyan Manufactur-

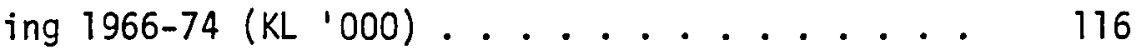

XXI Distribution of Economically Active Population Selected Years (in thousands)........ 119

XXII Poverty Groups . . . . . . . . . . . 120

XXIII Summary of Wage Employment by Sector, 1974-80 (in thousands) ................. 122

XXIV Summary of Manufacturing Output and Employment Growth, 1971-79 .............

XXV Estimate of Total Employment in Large Scale Manufacturing by Sector and Foreign Ownership Groupings, (1976)

XXVI Change in Formal Sector Employment, All Sectors $(1967-78)$ 
XXVII Distribution of Wage and Manufacturing Employment, by Ma in Towns, 1978 .......... . . 129

XXVIII Summary of Kenya's External Trade, 1970 and 1975-

79 (KL million) ................. 130

XIX Summary of Total Exports, 1975-79 (Percentage Shares) .................... 131

XXX Destinations of Kenyan Exports 1970-1979 .... 134

XXXI Summary of Total Imports, 1975-79 (Percentage Shares) ............... 135

XXXII Summary of Kenya's Balance of Payments (Millions of Kenyan Pounds) . . . . . . . . . . 136

XXXIII Economic Aid to Kenya, 1963-1980 (KL '000) . . . 139

XXXIV Summary of Kenya's Outstanding Debts 1974-79 (Mi1-

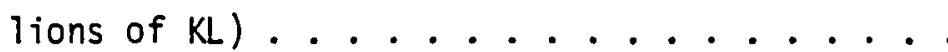

XXXV Summary of External Debt Charge Related to Export 1974-1979 ........................ 142

XXXVI ICDC, Sources of Finance .......... 152

XXXVII Enrollment Statistics by Educational Level and Year.................

XXXVIII School Leaver Residuals by Educational Level,


163

XXXIX Public Sector Manpower Projections, 1979-83 ... 165

XXXX Summary of Primary School Candidates and Residuals

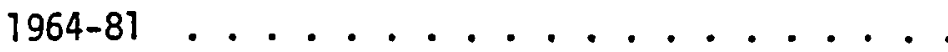

XXXXI Opportunities for CPE Candidates, 1975 by Type of School nad Province . . . . . . . . . . 
XXXXII EACE EXamination, Performance of Candidates . . .

XXXXIII Form VI Leavers and Candidates Admitted Into the

University of Nairobi and Kenyatta University

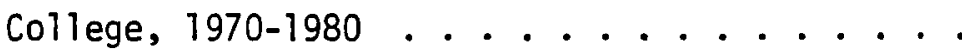

181

XXXXIV First Year After School Opportunities by Type of

Secondary School Attended, 1968 School Leavers . 183

XXXXV Population in Kenya (\%) . . . . . . . . . 184

XXXXVI Percent of Casual Labor in the Formal Sector, $1977 \quad 187$

XXXXVII Rate of Growth of Main Towns (Over 10,000) 1969-79 189

XXXXVIII Percentage Distribution of Levels of Educational

Attainment for Men Who Migrated to Each of Eight Urban Centers ............. 190

XXXXIX Proportion of Africans Seeking Work in Nairobi, by

Age and Level of Education 1970 (Percentages). .

$L$ The Percentage Distribution of the Nature of Employment of Men Prior to Their Rural-Urban Migration 192

LI Expansion of Polytechnic Program . . . . . . 201

LII Summary of Employment for Vocational School Graduates in Kenenya and Othaya ........ 206

LIII Secondary Technical Schcol Graduates' Status After DIT Intake, 1974 and $1975 \ldots . . . . .$.

LIV Estimates of Unit Recurrent Costs of Formal Education 1975-76 (KL) ............. 212

LV Estimated Recurrent Cost per Student by Type of Institution, 1978-79 (KL) . . . . . . . 213 
$x i \mathrm{i}$

LVI Summary of Employment Policies and Instruments . . . 218

LVII Registration Under Tripartite Agreement (December 1970) ......................... 222

LVIII Registrations as Indicators of Demand for Employment 223

LIX Placement Under the Tripartite Agreement (December 1970)...................... 224

LX Registered Job Seekers Against Declared Vacancies



LXI Summary of the Employment Trend: The 1970 and 1979 Tripartite Agreements . . . . . . . . 227 


\section{LIST OF FIGURES}

FIGURE

PAGE

1. School Enrollments ........... 62

2. Secondary School Expansion, 1964-77 . . . . . 72

3. Secondary School Enrollments ........... 74

4. Structure of ICDC Organization ........ 148

5. ICDC and the Policy Environment ........ 150

6. Expansion of Employment and Enroliments . . . . 162

7. Structure of Education . . . . . . . . . 168

8. Expansion of Employment and Enroliments . . . . . 171

9. Projected School Enrollment 1980-1993 . . . . . 175

10. Domains of Industrial Training Activity--1975 . . 199 


\section{CHAPTER I}

\section{INTRODUCTION AND REVIEW OF THE LITERATURE}

The main purpose of this study is to investigate those socioeconomic, historical, and political factors which best explain the sources of graduate unemployment in Kenya. In the academic research, education and economic growth are generally agreed upon to be central components of national development, particularly as they relate to the expansion of employment opportunities. However, current thinking on national development does not agree as to the interrelationships between these variables and, as a result, there is a divergence of opinion concerning the type of developmental approaches which should be taken to resolve the unemployment problem. This study is an attempt to empirically verify the historical roots of the prevailing social problem of graduate unemployment and Kenya's attempt to address it.

In order to gain a better understanding of the problem, it is necessary to examine the socio-economic evolution of Kenya in very broad outline form, starting from the early colonial intrusion of the country. This is justified because the present economic, social, and institutional (educational) structure of the country has characteristics whose origins date from different key formative periods: (a) the incorporation of Kenya into the international economy through the process of colonialism (1846-1963); (b) the shaping of Kenya's social 
relations as the country's links with the international economy changed in the context of decolonization (1950-63); and (c) the performance of the post-independence Kenyan economy as shaped by internal and external interplay. These externally-manipulated historical changes led to some structural economic changes and much institutional continuity in the post-independence period. The central task of this study, is, therefore, to determine to what extent dependency conditions the relationship between the educational system and the economy and distorts manpower planning in Kenya.

\section{THE PROBLEM}

Kenya, unlike many African countries, has enjoyed a relatively high rate of growth (we11 over 6\% per annum between 1964-70) and is regarded as a model of economic development for other African states. However, a closer examination of the Kenyan economy reveals many sources of potential conflict which have not been addressed by policies which emphasize economic growth. Central to the urban unemployment problem is the potential conflict arising out of a rapidiy growing number of school leavers* on the one hand, and on the other, the limited opportunities for a sufficient level of employment for this segment of the labor force. In the first few years after independence, the problem was confined to the primary school leavers.

In the context of Africa, the term "school leaver" refers to three categories of students: those who complete a certain level of education (primary or secondary) but are unable to continue due to a lack of school opportunities; those who drop out for any reason; and those who graduate. 
But since the early 1970's, secondary and technical school graduates and increasing numbers of university graduates have been experiencing difficulties in securing employment. The school certificate is no more a guarantee of economic success for the majority of Kenyan students.

What are the factors that condition the paradox of a developing country such as Kenya which clearly needs more educated manpower, but is unable to use it when it becomes readily available? Is education at fault? Has it expanded too rapidly? Has it produced the wrong kind of manpower? Or does the fault lie elsewhere--perhaps in the economy, or in economic development policies and plans? This study attempts to untangle the complexity of the problem by raising some important questions, taking into account the social, economic, and political predicament in which the nation of Kenya finds itself.

\section{LITERATURE REVIEW}

For the past three decades, Western development theorists have been enthusiastic about the contribution of education to economic development and employment opportunities in developing nations. Students of socio-economic development emphasize education as an agent of sociocultural change that develops human capital, influences the formation of elites, and modernizes attitudes and behavior in the general population (GR4; GR67). Economists and governmental officials have also emphasized that education can produce the knowledge and ski11s required for economic development (GR45; GR54; GR61; GR139). Based on this assessment, many developing countries have concentrated 
on expanding the educational system from primary school through the university. For example, primary school enrollments in Ghana almost tripled between 1960 and 1970. In Gambia and Botswana, enrol1ments more than doubled between 1960 and 1970. In Kenya, Zambia, and Sierra-Leone, enrollments nearly doubled during that same period (GR37: 20-21). This development suggests not only a general rise in the level of literacy, but also substantial increases in access to educational opportunities for Africans.

In recent years, however, serious questions have been raised which challenge some of the traditional assumptions about the effects of education on economic growth and social mobility (GR29; for US, see GRT9 and GR71). The efforts to rapidly expand educational opportunities have not been without problems. Despite the heavy investment in education, unemployment of school leavers has become a matter of growing concern--even political discontent--in many cases, as these developing countries do not have sufficient employment for school graduates (GR1; GR52; GR59). Even in the early 1960's, Archibold Callaway found that unemployment among primary school leavers in Nigeria had reached serious proportions (GR26). A more recent report found that in Western Nigeria, $41 \%$ of the primary school leavers were without employment nine months after leaving school (GR43). In Kenya, a 1968 tracer Project indicated that of a total of 1,186 secondary school leavers, 175 (14\%) remained unemployed in their first year after school. The remaining leavers were distributed as follows: 513 (45\%) undertook further education, 394 (33\%) were employed, and the remaining $86(7 \%)$ were untraced (GR88). In the 1975 Certificate 
of Primary Education examination (CPE), of 220,000 candidates, approximately $150,000(68 \%)$ failed to gain admission to secondary schools. Of these, some found work; others joined the ranks of the unemployed. This growing problem suggests that the further rapid expansion of formal education beyond the literacy level without constructive efforts to create meaningful employment opportunities is likely to generate political as well as educational unrest.

The unemployment situation among school leavers has worsened in Kenya since 1968, for two reasons. First, there is a paucity of secondary school openings for those who want to continue further in their education, even though the demand for education has increased. Secondly, despite an impressive rate of growth in the GNP $6 \%$ per annum between 1960-70), employment in the modern sector of the economy has not been growing in a direction that would absorb the thousands of schnol leavers. The policy measures which should be adopted to resolve this developmental dilemma are the subjects of heated and sometimes bitter arguments.

Two contrasting approaches are frequently discussed in the literature to analyze the development and underdevelopment of Third World nations. The first is embraced by the "diffusion model," which suggests that the development of areas such as Africa will come about only through closer association with the developed countries of the West in a much more comprehensive technological, even ideological, sense. The second explanation, incorporated into the "dependency model," views foreign penetration into the political and economic structure of the Third World as a conditioning factor and implies 
that development can occur only if both internal structures and Third World relations with other nations undergo a complete change.

The purpose of this critical literature review is twofold:

(1) to outline the various explanations offered by these two approaches regarding the relationship between education, economic growth and employment; and (2) to examine the extent to which the dependency relationship has influenced the structuring of post-independence Kenyan society and the degree to which it conditions manpower planning.

The Diffusionist Perspective and the National Development Experience in Africa

During the 1950's and early 1960's, one of the major doctrines of the development literature was that successful economic development in Third World countries could be realized only through substantial capital accumulation and rapid industrial growth (GR4; GR136). Rapid growth, it was argued, is the surest means of increasing the standard of living for most, if not all, members of society.

In addition to emphasis placed on economic growth as the key process in development, social scientists paid particular attention to the spread of the social, cultural, and political patterns of modernity established by the developed countries of the West, such as education, political parties, and urbanization (GR4; GR67). It was suggested that rapid growth in all of these areas would inevitably transform Third World nations into modern states. Based on these assumptions, social scientists looked to identify the proper "inputs of modernity," which, if installed in Third World countries, would ensure 
the progressive "stages" necessary for "take-off" (GRT36). This view constituted the basis on which Kenya's development strategies have been created.

In order to help Third World nations such as Kenya improve their economic performance, flows of foreign aid and investment were channelled to them from the West. This policy was further reinforced by bilateral and multilateral aid agencies such as the World Bank and the United Nations, which set growth targets and devised performance indicators on the basis of which assistance was allocated (GR34). In many instances, growth rates did accelerate, and the tempo of expansion was much faster than once thought possible. For example, the Kenyan economy experienced a relatively rapid rate of growth of real monetary GDP--we11 over 6\% per annum for 1964-70 (KG7, 1971). As a result of this trend, the average $5 \%$ growth target of the First United Nations Development Decade (1960-70) was achieved quite readily, and accordingly, the target was raised to $6 \%$ for the Second Development Decade (1970-80). As this study will demonstrate, an inevitable consequence of the emphasis on growth has been the mushrooming of urban centers resulting from an accelerated influx of both educated and uneducated workers in search of scarce urban jobs. Unfortunately, optimistic predictions regarding the ability of the modern industrial sector to absorb these migrants have not been realized. In actuality, the failure of the modern urban industries to generate a significant number of employment opportunities is one of the most obvious failures of the development process over the past two decades. 
The realization that growth does not necessarily mean development has led to a re-examination of the development process itself in at least two important respects. First, the traditional argument that rapid growth is a necessary condition for higher standards of living for the masses has been retrospectively criticized on the grounds that growing inequality now is too high a price to pay for a future higher aggregate output. Proponents of this view urge that the goals of development planning or policymaking be redefined to include reduced inequality as well as increased output; if necessary, some growth should be sacrificed to achieve a better distribution of available output (GR2; GR21; GR33; GR69). The re-examination process has also obviated the logic that without growth, there will be little to redistribute, now or later; many planners and academicians have begun to ask whether there aren't better ways to grow. This, in turn, has given new impetus to a fundamental debate over the sources of development or underdevelopment and the extent to which inequality is a necessary concomitant of growth.

Education and Development: The Human Capital Approach

A prominent feature of deliberate progress in modernization is an emphasis on formal education. Students of socio-economic development emphasize education as an agent of change that develops human capital, influences the formation of elites, and modernizes attitudes and behavior in the general population (GR1; GR4; GR67). Economists and government officials have emphasized that education can produce the knowledge and skills required for economic development (GRT8; GRGR20; 
GR61; GR139). Thus, a consistent theme contained in the human capital literature is that accelerated development depends upon enlargement of the supply of educated manpower which, in turn, depends on a broadening of access to a formal educational system.

This logic seems straightforward. Developing nations such as Kenya were deficient in their supply of skilled manpower at the time of independence. Without such manpower, which it was assumed could be created only through the formal educational system, development leadership in both the public and private sectors would be woefuliy lacking, and economic growth would be retarded. Rapid quantitative expansion of enrollments, therefore, appeared justified in light of the substantial manpower scarcities of the early 1960 's. As a result, Kenya and other developing countries have concentrated their attention on the rapid quantitative expansion of the educational system from primary school through the university.

The role of education in the development process has been clearly articulated by economist, Theodore Schultz (GR139) and is incorporated in what is known as the human capital theory, an offspring of the diffusion theory. The emphasis of this theory is on the development of knowledge, skills, and capacities to improve the rate of societal economic progress. The task of translating this theory into application in underdeveloped countries was strongly influenced by the work of economists such as Mark Blaug (GR18), Frederick Harbison and Charley Meyers (GR61), and Mary Jean Bowman (GR20). The human capital theory suggests that: 
The nations of the Third World were poor not because of international economic relations, but because of internal characteristics, most notably, their lack of human capital. As with the poor within the advanced countries, nothing in the situation of the Third World countries called for radical structural change; development was possible if only they would improve the quality of their woefully inadequate human resources.

(GR80: 15)

The proponents of this school of thought argued that the rapid recovery of Western Europe with American capital through the Marshall Plan could be largely attributed to the existence of a ready pool of qualified manpower. Hence, less developed countries, lacking in the "knowledge and superior technique of production," should be provided with aid and technical assistance to increase the quality of their human capital, which would result in their achieving self-sustaining growth (GR80: 15). Development, in this sense, means an educated society and an educated labor force. Subsequently, international organizations (World Bank, ILO, UNESCO) and foundations (Ford Foundation, Rockefeller foundation) responded to this perceived need by channeling their funds into educational and training programs in underdeveioped countries. As Kinyanjui succinctly put it,

What American capital had done in Western Europe was expected to happen in underdeveloped countries if they invested more in the development of their human resources and more foreign capital was channelled into these countries.

(GR86: 7)

In their well known study, Education, Manpower, and Economic Growth (GR61), Harbison and Meyers stressed the point that the appraisal of human capital is a logical starting point for analysis of growth 
and modernization in underdeveloped countries. They argued that education, in addition to being a form of consumption, is also an individually and socially productive investment which contributes to economic growth. According to Harbison:

Human resources constitute the ultimate basis for the weal th of nations. Capitai and natural resources are passive factors of production; human beings are the active agents who accumulate capital, exploit natural resources, build social, economic and political organizations, and carry forward national developments. Clearly, a country which is unable to develop the skills and knowledge of its people and to utilize them effectively in the national economy will be unable to develop anything else.

\section{(GR61: 3)}

This approach to development was echoed in African countries in the years immediately after independence and, to a large extent, accounts for the rapid expansion of higher education in the 1960's (GR56; GR72). The result of such expansion has been ever-burgeoning educational budgets in most developing countries. It is estimated that, on the average, $16 \%$ of the national budgets of developing countries are now being spent on education. Between 1960 and 1970, the annual growth rate in educational expenditure was $13 \%$ in Asia, $16 \%$ in Africa, and 20\% in Latin America (GR26: 14). Many countries, including Kenya, allocate as high as $3 \mathrm{C} \%$ of their government's expenditure for education (GR37: 21).

The influence of the human capital approach on the study of education and development in Kenya is clearly evident from an examination of various documents (both official and unofficial) that have been published since independence. The predominant themes of 
these documents are: (1) that education must foster a sense of nationhood and promote national unity; and (2) that education must provide the skills and knowledge required for national development. These views are expressed in the Kenya Education Commission Report of 1964 (better known as the Omindi Report), the 1970-74 Development Plan, and the Report on the Educational Goals and Objectives of 1976. The result of this policy has been the tremendous quantitative expansion of the educational system from primary school through the university. As a result, the educational budget now consumes nearly $30 \%$ of the total governmental expenditure (KG6, 1980). Thus, money and resources were channelled into tremendous expansion of a system still largely cast in a colonial mold. Fundamental changes of structure, curriculum, examination, and, indeed, the whole style and approach of the educational system were postponed.

In recent years, however, the idea that conventional educational expansion beyond literacy is an unmitigated social good and an engine for development has been fundamentally challenged. In the present context, the most crucial challenge is taking the form of growing open unemployment in urban areas. Although the evidence is fragmentary, the following examples provide indications of the problem. In the late 1960's, the rates of urban unemployment in the 15-24 age group reached tremendousiy high percentages: $40.4 \%$ in Guyana, $39.3 \%$ in Algeria, 39\% in Jamaica and Sri Lanka, 21\% in Malaysia, and 22\% in Ghana (GR151: 48-50). This trend suggests that the further rapid expansion of formal education beyond the literacy level without constructive efforts to create meaningful employment opportunities is 
likely to generate political as well as educational unrest.

Since gaining independence, Kenya has experienced economic growth largely continued on the lines set by the earlier colonial structure. Such continuity in policy has had two related consequences. On the one hand, this growth has resulted in a rapid rate of real monetary GDP, we11 over 6\% per annum for 1964-70 (KG7, 1971). Kenya's greatest advantage has been in the manufacturing sector, which, for example, accounted for 13\% of GDP in 1979 (KG6, 1980). On the other hand, the so-called "Kenyan miracle" of the 1960's has not resulted in a similar expansion of employment opportunities to absorb the thousands of unemployed Kenyans, including school leavers. Instead, there have been serious inequalities of income among regions and social groups. These sharp inequalities inevitably create strong ambitions to migrate to the cities, to strive for higher education, to search for jobs. These structural characteristics, from the main thrust of development, constitute the basic weakness of the economy and militate against the effective development of the country.

Originally, the goal of the educational policy in postcolonial Kenya was the production of skilled manpower. However, when faced with the problem of unemployment of school leavers whose aspirations are oriented to urban jobs and an urban way of life, the human capital theorists have been critical of education for being dysfunctional in the sense of inculcating wrong values. To correct this perceived developmental problem, the task of the educational system was reoriented, not only to produce skills and knowledge required for high-level manpower, but also to indoctrinate school leavers to settle down in the 
rural countryside as subsistance farmers and self-employed artisans. The vocational and nonformal education programs introduced in Kenya since the early 1970's are intended to achieve this goal. But, as discussed in Chapter IV, many of these educational reforms solved an immediate political problem by offering a new outlet for the economic aspirations in Kenya. The impact of these educational strategies on the employment prospects of school leavers has been severely 1 imited by the restricted market for technical and vocational skills in the country.

\section{A Critique of Diffusion and Human Capital Theories}

Many of the early claims made on behalf of the unfettered quantitative expansion of educational opportunities--that it would accelerate economic growth; that it would raise levels of living, especially for the poor; that it would generate widespread and equal employment opportunities for all--have been shown to be greatly exaggerated and, in many instances, simply false (GR19; GR29; GR71). The most devastating challenge has been the glaring poverty of Third World countries despite three decades of developmental efforts. The failures of foreign aid and Western technology to transform these countries, the growing disparities between the rich and the poor, the relative poverty of Third World nations in the international community, and the rising unemployment of the educated in these countries demonstrate clearly the analytical weakness of the diffusion and human capital approaches. These theoretical formulations neglected the structure and patterns of economic growth and their distributional implications. 
They failed to properly identify the actual beneficiaries of economic development.

By far the most crucial weakness of the diffusionist model is its inability to address itself to structural problems of underdevelopment. The theoretical framework contributes very little to constructing explanations of change based on factors residing outside the national boundaries of Third World nations. The problems associated with imperialism, colonialism, and neocolonialism in the emergence of Third World countries are not given the attention they deserve. A somewhat more complex analysis is required--one which stresses many other factors of both an economic and a noneconomic nature.

\section{Alternative Explanations: Dependency and "Revised Dependency"}

Dependency theory has gradually emerged as a major alternative to the prevailing paradigm of the 1960's. The primary focus of dependency analysis is on the problem of foreign penetration into the political economies of Third World nations (GR53; GRI38; GR148). The basic hypothesis of the Dependency Theory is that development and underdevelopment are partial, interdependent structures of one global system. Dos Santos, for example, conceptualizes dependence as a conditioning situation which determines the range of options open to policymakers:

By dependence we mean a situation in which the economy of certain countries is conditioned by the development and expansion of another economy to which the former is subjected. The relationship of interdependence assumes the form of dependence where some countries (the dominant ones) can expand and be self-sustaining; while 
other countries (the dependent ones) can do this as a reflection of that expansion, which can have either a positive or negative effect on their immediate development.

(GRT38: 109)

The conditioning process referred to by Dos Santos has its origin in the expansion of capitalism into the underdeveloped world over the last several centuries. The most significant consequence of the Western impact upon Third World societies was the fusion of market and social structures through the establishment of the international division of labor (GR13; GR53). Colonial areas became a source of cheap raw materials as well as a market for manufactured exports and investment capital from the West. This characteristic remains the basic foundation of the economic relationship between the developed and developing countries to this day. An understanding of dependency, therefore, requires an analysis of economic relationships in the capitalist countries of the West and their expansion to the Third World, and the compromises and collusions among the various international and national elements which create the dependent situation.

Dependency theory is probably most closely identified with the work of Andre Gunder Frank. In his book, Capitalism and Underdevelopment in Latin America (GR53), Frank argues that the development and expansion of capitalism in the periphery began and furthers an unequal and combined development of its constitutive parts. Growth is unequal because dependent nations can only grow as a reflection of the expansion of dominant nations. He refers to development as "combined" because it 
is the combination of inequalities plus the transfer of a significant part of the economic surplus produced in the Third World to developed countries which explains inequality, deepens it, and transforms it into a necessary and structural element of the world economy. Thus, capitalist expansion creates underdevelopment by concentrating wealth at one pole--the metropolis--and poverty at the other--the satellite (GR53: 6). These internal and external dimensions of metropolissatellite relations are structurally similar, interlocked, and mutually consistent. In Frank's view, these relationships are crucial factors shaping the political and economic systems of Third World nations.

The economic and socio-political connections between satellites and the metropolis create mutually beneficial links between local elites and external interests that give the former a vested interest in the preservation of the status quo. Even after decolonization, the national elite of Third World countries pursued a policy of "accomodation" with the former colonial masters in order to maintain access to capital, technology, skilled cadres, and markets (GR137). Many of these leaders still view such institutional continuities as necessary for their immediate goal of rapid economic growth. Consequently, they reject major structural changes in the inherited economic system so as to avoid a disruption of their valued connections with the West.

For dependency theorists, the outcome of the above described historical process is an asymmetrical structure of relations between the metropolitan and satellite states, accounting for the widening gap in levels of development between them. Because of its historical 
perspective, the notion of dependency has come to be uniquely associated with international capitalism. This literature has been criticized on the grounds that dependency theory cannot explain imperialistic relations among socialist countries, as in the case of the Soviet Union and Eastern Europe (131). However, Finley's (GR49) preliminary research on Economic Linkage and Political Dependency in Eastern Europe contradicts Ray's premature conclusion. Finley concludes that Eastern European dependence on the USSR both reinforces and complicates the overarching system of political dependence. Recent political events in Poland support Finley's position. This suggests that dependency reduces the capacity of governments to determine the course of national development autonomously, irrespective of their ideological orientation. And to the extent that African nations remain dependent upon foreign trade, foreign investment, and foreign assistance for the creation of wealth and the provision of goods and services, demand and decisions adopted in the developed economies of the West become permanent inputs into the national policymaking process. Under such conditions, dependent nations have little prospect of self-sustained economic growth.

Relevance of Defendency Analysis for Africa and Kenya

The Frankian notion that underdevelopment is a logical outcome of an ongoing historical process has received widespread acceptance among such Africanists as Rodney (GR134), Amin (GR5), Leys (GR105, GR106), and Arrighi and Saul (GRII). They argue that the incorporation of Africa into the emerging world capitalist economy, first 
through a direct colonial administration and then, more subtly, through free trade, ensures that African production is geared towards producing exports for the dominant economies of the West. The political and social system also ensures that the gains from this production are divided among a small African class (who use much of their gain for importing luxury consumer products rather than diversifying investments) and the dominant metropolitan countries. In the present context, this external relationship both threatens and inhibits autonomous and self-sustaining growth.

Since the mid-1970's, Kenya, as well as the Ivory Coast and Nigeria, has become the subject of intense scholarly investigation which has spurred a major academic debate. One school of analysts has interpreted the country's performance in terms of a dependency framework, stressing widening inequalities and structural segmentation, and relating these elements to the growing ties with foreign capital which have marked postcolonial Kenya (GR 76; GR100; GR105). Another school, mainly "revised dependentistas," have challenged this view, stressing the role in Kenya of an increasingly powerful indigenous capitalist class, in effective control of the Kenyan state and leading a relatively dynamic capitalist transformation in the country (GR106; GR149). This debate has been significant because of its relevance to more general theoretical and strategic concerns regarding the economic prospect of "periphery capitalism" and the usefulness of a dependency perspective.

The groundbreaking study on dependence and underdevelopment in Kenya is Colin Leys's Underdevelopment in Kenya, The Political Economy 
of Neo-colonialism (GR105). According to Leys, Kenya has been incorporated into the international capitalist system since the colonial period, and such incorporation has deprived Kenya of the resources (human and material) necessary to pursue an autonomous development. Furthermore, external penetration served to introduce capitalist socio-economic structures within Kenya. The emergence of these structures has created a new social stratum from among the indigenous population, with an interest in organizing and facilitating the new activities involved (trade, mining, crop production, commerce, etc) (GR105: 9).

The ongoing impact of external ties is shaping internal social relations within Kenya, maintaining the dominance of social classes tied to foreign interests (GRI00; GR105; GRI34). One segment of the working class, connected with the modern economic sector, does indeed benefit substantialily from the policy of "dependent development," while the segment associated with the traditional sector essentially does not. The implication of this situation is increased inequality between the emergent "labor aristocracy" of workers in the modern sector and the mass of people who can, at best, make periodic forays into the wage economy as migrant labor (GR12). From the perspective of national planning, this structural characteristc creates a problem for policymakers in Kenya. As Leys points out:

All governments of periphery countries could of course prefer better terms of trade and less dependence on foreign technology, but in most cases the social strata and classes which they represent have not been willing to make the sacrifices which a serious attack on these patterns would imply. It is artificial to point to the existence of theoretical al ternatives, without 
recognizing that the status quo is underwritten by

the social classes which underdevelopment has

created and brought to power in the periphery

countries.

(GR105: 13)

The present pattern in Kenya does not lead to "autonomous" development, but to a further consolidation of underdevelopment. The growing inequalities among regions and among social groups, rising import bills, and balance-of-payment difficulties are logical outcomes of Kenya's subordinate role in the international economy. And to the extent that Kenya remains a dependent nation, the objectives, intensity, and efficiency of development policies are limited within certain margins of flexibility.

Similarly, Langdon (GR102) and Kaplinsky (76) argue that Kenya has not developed an autonomous capacity to sustain capital accumulation through internal interaction among sectors of the economy. In asserting the dependency position, they point first to the limited achievement which characterizes Kenyan economic development in general and that of industry in particular. Despite the high growth rate in the fields of investment and industrial output, the growth of employment in urban and rural areas has lagged far behind manpower growth, which has become the most crucial developmental problem in the country. The growth of a modern, import-substituting sector has proven to be capital-intensive and labor-displacing. As a result, the government's ability to provide productive employment, even to those who are educationally qualified, is severely limited. The key to Kenya's dependency is the penetration of the economy 
by multinational corporations. Langdon (GR102) and Kaplinsky (GR76, GR78) argue that the penetration of multinational corporations into the Kenyan economy has shifted the basis of metropolitan penetration from commerce to industry. Such penetration, according to Langdon, generates technological and social dualism in the economy, and these structural and distributional effects reshape class structure in the periphery--as parts of the usual class formations are integrated into the transnational community and other parts excluded. This reshaped class structure generates changed dynamics in the periphery political economy.

(GR102: 27)

Dependency analysis, therefore, views multinational corporations as the agency of a dual process of transnational integration and national disintegration (GR148). And in terms of Gunder Franks' definition, the multinationals are helping generate the "development of underdevelopment" in Kenya.

On the whole, Leys, Langdon and Kaplinsky (all proponents of classic dependency analysis) agree that because of Kenya's external dependency, the policy decisions of the government are strongly influenced, if not determined, by internal consequences of foreign trade, foreign investment, and foreign assistance. The result is that the amount of resources available to the government of Kenya to support public policies aimed at providing employment opportunities depends to a significant degree, on external rather than internal conditions.

"Revised Dependency Analysis: the New "Orthodoxy"

Early theories of imperialism, such as those espoused by Paul Baran (GRI3), argued that the relationship between dependence and 
higher levels of inequality occurred because foreign capital supported "semi-feudal" elites, and thus impeded industrialization. In the seventies, however, it seemed plausible to argue, as Bill Warren did, that foreign investments are likely to be associated with the intensification of capitalist accumulation in the Third World (GR160: 92-107). Warren demonstrated, by way of a statistical survey, that:

- industrial growth has taken place in the Third World since World War II;

- growth in the Third World, during this period, has increasingly been based on home market consupmption;

- such growth has created important intermediate sectors;

- foreign capital investment has been decreasing;

- independent technological development has been occurring;

- dependent development has become a characteristic feature of many formerly underdeveloped countries.

Warren's position has won over many converts to the idea of "dependent development," two words considered inimical to each other by earlier dependentistas such as Frank. The basis of this position is the observation that industrialization and growth are occurring in many areas of the Third World, and the control which foreign capital once enjoyed is rapidly diminishing (GR27: 89-90; GR47: 32). This stage, which is characterized by an alliance between domestic and international capital, might also describe Brazil, Mexico, South Korea, Taiwan, Hong Kong, Nigeria, and the Ivory Coast. It has particular importance in the Kenyan case, as argued by Leys (GRI06) and Swainson (GR149). Whatever the differences among these countries, and there are many, 
the common elements are the dynamic patterns of industrial growth and their close integration with the international capitalist system. To the radical academic, these countries form a "semi-periphery" between the rich and the poor, while to many liberal analysts in the developed world, they are "newly industrializing countries," held up as the success stories of the 1960's and 1970's.

The proponents of revised dependency analysis argue that Kenya is in a position to determine the process of economic development autonomously. The principal force of this process, they say, is the emergent domestic bouregoisie and the state apparatus under its control. Nicola Swainson (GR149), and most recently, Colin Leys (GR106), argue that since Kenya's independence, the dominant factions of the African capitalist class have been able to commandeer the state apparatus and use their power to break into areas of accumulation that were off limits to Africans during the colonial period. They insist that the Kenyan bourgeoisie is not a foreign/metropolitan creation, but a class which developed within Kenya itself, and was subsequently held back by colonialist policies.

Both sides in the Kenyan debate recognize the movement toward tighter state control on foreign capital in Kenya in recent years. The principal measures taken by the state to expand the sphere of indigenous accumulation include loans, licensing, and public investments. But their analysis of this development reflects differing views of the state and of class relationships within Kenya. Swainson, for instance, sees clearly the increased application of such controls as a function of the indigenous bouregoisie's movement into industrial 
production and use of its dominance over the state to facilitate private accumulation, mainly by restricting foreign capital--a sign of state strength. Kaplinsky and Langdon, on the other hand, see the roots of such efforts as attempts to deal with the growing foreign exchange gaps inevitably shaped by a transnationally-dominated importsubstitution industrialization strategy and as reflections of concern by middle-level and other state functionaries who have shared little in the considerable benefits of symbiosis in Kenya.

Despite the points of disagreement, both sides in the Kenyan debate agree that the present pattern of development is subject to growing limitations and blockages and is increasingly dependent on external economic events. Most dependentistas agree that Third World nations have lost control over decisions affecting their national economies as a result of linkages established through foreign trade, foreign investment, and foreign assistance (GR53; GR105; GR138). These three components of national dependence emerge as significant characteristics affecting the policy decisions of Third World governments for the following reasons:

(a) Countries which are hosts to large amounts of foreign investment (relative to their wealth and population) are likely to experience high levels of inequality among regions and social groups (GR31; GR42; GR55). The heavy penetration of foreign capital, mainly in the form of direct investment by multinational corporations in the mineral, plantation, and light manufacturing sectors, is highly profitable to foreign investors and results in a large return flow of income to metropolitan centers. 
(b) Foreign investment enhances the possibility of the transfer of capital-intensive production techniques which are inappropriate to the needs of the developing nations, having been imported unchanged from the industrial countries (GR14; GR76). Capital-intensive technology generates little employment, and, if anything, it eliminates employment. Since investment decisions by the multinationals are based on a plan for improved profitability, minimizing labor cost is their first target. This means that the employment needs of a host country, such as Kenya, are relegated to a secondary position.

(c) Countries which rely heavily on the export of a few primary products such as coffee and tea are likely to experience continued underdevelopment since international trade is characterized by unequal exchanges of goods and services (GR5; GR46). Because of the dominant position of developed economies in the world market, Third World governments are not in a position to bargain effectively to achieve a comparative advantage of trade. In effect, the demands for and the value of the different commodities of Third World nations is determined by events within the developed economies. This point is clearly demonstrated in the Kenyan case when, in 1977, the price of Kenyan coffee dropped substantially, which was responsible for subsequent balance-of-payment difficulties.

(d) The transfer of public foreign assistance required for development carries with it elements of cost relating to structural dependency (GR137: 274). Aid entails a further loss of national power of decisionmaking and adds a new dimension to dependency. Aid brings with it the rights of donors to take part in policymaking and the 
necessity for dependent countries to constant?y justify their policies in order to continue the inflow of foreign aid (GR63; GR159). A final cost of aid is in the interest required in its repayment; this also contributes to the spiraling debt and balance-of-payment problems.

On the whole, the consensus among dependentistas is that foreign aid, foreign investment, and foreign trade are essential components of the decisionmaking environment within Third World nations. Each of these aspects of national dependency poses both potential influence and potential constraints on the actions of Third World governments because of its impact on the amount of available resources, the distribution of political power, and the intrusion of external decisionmakers into the national policymaking process (GR166). Logical extensions of the above assumptions of dependency analysis lead to an expectation of the following structural characteristics in Kenya:

- agricultural stagnation resulting from adverse terms of trade, urban migration, and low rates of surplus and reinvestment, leading to urban food shortage and structural inflation;

- continued balance-of-payments crisis requiring dependence upon foreign finance to a growing degree, and perhaps repeated devaluation of the Kenyan shilling;

- noncompetitive domestic industrial sector with powerful trade unions, resulting in employers and unions forcing urban wages and prices upward to protect against rising import and food prices, further feeding inflationary 
tendencies; and

- increased urban migration as agricultural terms of trade deteriorate, resulting in explosive growth of shanty towns around Nairobi.

\section{Educational Research and the Dependence Perspective}

Despite the recent interest in the internal dynamics of peripheral capitalism, dependency theory has, on the whole, inspired very few studies on education. Indeed, the studies which have attempted to develop a Marxist point of view about the interaction between schooling and the labor market have not come from the existing studies of underdevelopment, but rather from studies of education in advanced capitalist countries, particularly the United States (GR19; GR21). There is no definitive study of education which utilizes the insights that have been gained from the recent debates on underdevelopment theory.

In the case of Africa, only Walter Rodney (GR134) has attempted to show the linkages between the development of Western education and the underdevelopment of the continent. Rodney view colonial education as merely "education for subordination, exploitation, and the creation of mental confusion" (GR134: 241). He argues forcefully that

The main purpose of the colonial school system was to train Africans to help man the local administration at the lowest ranks and to staff the private capitalist firms owned by Europeans. In effect, that meant selecting a few Africans (a process of incorporation) to participate in the domination and exploitation of the continent as a whole. It was not an educational system that grew out of the African environment or one that was designed to promote the most rational use of material and social resources. It was not an 
educational system designed to give young people confidence and pride as members of African societies, but one which sought to instill a sense of deference towards all that was European and capitalist.

(GR134: 241)

As Rodney clearly identifies, the main purpose of colonial education was to provide trained manpower to run the colonial economic structure. It was not intended to give skills that would use African resources for autonomous development of African societies. The quality, context, and quantity of education given to Africans was different from that offered in European schools. In fact, the colonial education system was racially segregated. The overall colonial educational policy was, therefore, to reinforce the destruction of the autonomy of African economies and to reorient them toward production for the dominating metropolitan capitalist economies. In this way, colonial schooling was part and parcel of the totality of the forces of underdevelopment, and its reproduction in the postindependence period must be examined carefully. As Kinyanjui (GR86) succinctly put it:
Western education, like political and economic structures planted in the colonies, was an essential part of the expansion of Western capitalist system. As part of the superstructure of the capitalist system, it had the double task of incorporating the colonized people into that system and reproducing the emerging relations of production.

(GR86: 29)

The implication here is that the educational system, in its present form, can become an instrument for social control and domination. This is contrary to the human capital assertions which suggest that 
there is a relationship between education and development.

Rodney also points out that colonial dependency generated unequal distribution of educational resources among regions and social groups. The districts that were closely integrated into the colonial economy (such as the coffee growing regions of Kenya and the former settlements of the missionaries) devoted many of their resources to the development of education. The result has been that these regions emerged as more developed than those that were not integrated into the colonial economy. This point is fully supported by Kinyanjui (GR85, GR87), who argues that post-independence governmental policy seems to have exacerbated the existing regional and societal differences, rather than minimizing the gap. Kinyanjui attributes this phenomena to the continued political and economic power of these developed regions.

On the whole, Africanists who adopt the dependence perspective in the study of the Kenyan political economy have ignored completely the role of education in the discussion of the underdevelopment process. The focus of their analysis has been the economic structure; they have paid scant attention to the superstructure and, in particular, to the educational sector. The ways in which education and the educational structure are affected by dependency are not given appropriate attention. The primary task of this study is, therfore, to examine how dependency conditions the relationship between the educational system and the economy and distorts manpower planning in Kenya. 


\section{RESEARCH DESIGN AND METHODOLOGY}

Public policy is considered to be the end product of the public decisionmaking process. It is, therefore, a dependent phenomenon which responds to changes in the factors which influence public decisionmaking. Among the factors which constrain policymaking is the problem of external dependency; namely, foreign aid, foreign investment, and foreign trade. Each of these aspects of national dependence influence the formulation and implementation of policies. Thus, the primary goal of the analysis is to determine the consequences of the dependency relationship on the efforts of the Kenyan government toward solving the urban unemployment problem.

The analysis of the extent to which external dependence affects the content of public policies is approached through an application of a policy analysis framework. Policy analys is combines two critical disciplines that are central to an understanding of the process of decisionmaking in the Third World: political science and economics. In an examination of the decisional choice by public authorities in achieving social, economic, and political goals, policy analysis framework is a useful means of inquiring into the interaction between social, political, and economic organization and process.

\section{Methodological Techniques}

The techniques of the methodology in this study include: historical analysis, field research, analysis of primary and secondary data, interviews of Kenyan governmental officials and technical assistance personnel. 
The following questions guide the research problem:

- In what ways does the educational system complement or contradict economic planning?

- To what extent has education met the political needs and priorities of the government?

- To what extent has the type of education offered by the institutions matched the education and training needed by the labor market?

- To what extent does Kenya's external dependency contradict or bedevil manpower planning?

\section{Analysis of Data}

The method of analysis used in this study is part historical and part quantitative. The field research was undertaken in Kenya between September 1981 and March 1982. The historical data on the restructuring of the Kenyan society and economy from colonial time up until independence in 1963 was collected from published reports and colonial governmental documents deposited in the National Archives.*

Secondary data on the economy and on education was collected from governmental sources (particularly the Central Bureau of Statistics at the Ministry of Economic Planning and Development), UNESCO, the Regional Mission of the World Bank, the East African Regional

The information generated highlighted the intense struggle between the colonizers and the colonized over the distribution of educationai and economic resources and opportunities and the Africans' reaction to the colonial restrictions. 
Office of USAID, the Swedish International Development Agency (SIDA), the International Labour Organization (ILO), and other Kenyan governmental ministries. Additional information was collected through in-depth interviews with leading governmental officials, politicians, foreign technical assistance personnel, and managers of foreign corporations. *

\section{SUMMARY}

The literature on development is replete with studies purporting to identify education and economic growth as central components of national development, particularly their relationship to employment. Nevertheless, the interrelationships between these variabies have not been substantiated by empirical evidence. While higher levels of educational expansion and economic growth, as measured in GNP, have been achieved in Kenya (see Chapter III), graduate unemployment has emerged as one of the most critical developmental dilemmas in the country. In the present context, three significant questions remain unanswered: (1) what are the historical roots of the prevai1ing social problem? (2) what attempts are being made by the government of Kenya to address this problem? (3) did these programs in fact alleviate the problem significantly? The first task of this study is, therefore, to provide some answers to these questions.

An additional element of the study is drawn from literature on

A total of twenty-five high-level officials from the private and public sectors were interviewed. The information generated through interviews was then used to further elaborate the secondary data collected. 
national dependence in Latin America. The central theme of this literature is that dependence affects the resources available to Third World governments and Teads to the intrusion of external decisionmakers into the national policymaking process. As a result, the policy decisions of these governments may be strongly influenced, if not determined, by the internal consequences of foreign aid, foreign trade, and foreign investment. The second task of this study is to determine to what extent dependency conditions the relationship between the educational system and the economy and distorts manpower planning in Kenya.

Although theorists have ignored the role of education in the discussion of the underdevelopment process, this study is an attempt to refine the components of dependency theory as they relate to policy decisions within Kenya by establishing empirical evidence as to the proposed consequences of dependency upon the linkages between education, economic growth, and employment opportunities in Kenya. 


\section{CHAPTER I I}

THE DEVELOPMENT OF WESTERIN EDUCATION IN KEIVYA, 1846-1980:

A CASE OF DEPENDENCY RELATIONSHIP

This chapter examines the development of Western education in colonial and post-colonial Kenya. Part I of this chapter investigates the intense struggle which took place between the three principal actors involved in the formulation of educational policy in colonial Kenya during the period between 1846 and 1963: (a) the European missionaries, (b) the colonial administrators and European settlers, and (c) the indigenous African population. Part II examines the relationship between the colonial legacy of Kenyan education and the pattern of national development since Kenya's achievement of independence in 1963.

THE STRUGGLE FOR POLITICAL CONTROL

\section{Colonialism and Economic Change}

Kenya's links with Western capitalism were forged in the late nineteenth century, when the world market was dominated by a few industrial giants such as Britain, France, and Germany. Kenya became a protectorate under Britain in 1895 and a Crown Colony in 1920 (GR22; GR 149: 22). Although missionary work in Kenya started as early as 1846 , it was not until the construction of the Uganda Railway in 1901 from Mombasa on the coast to Lake Victoria that significant European influence took place in Kenya (GR15; GRI12: 1-7). The construction of the railway 
spearheaded the integration of Kenya into the colonial system. The British policy during the following years was determined by the need to make the colony pay its own way, that is to pay back the loans for the railway and to put an end to the need for annual grants from Britain for the administration of the Protectorate (GR105; GR149). The way chosen to accomplish this was to try to establish a white settler agriculture which could produce for export. The administration encouraged European settlers from South Africa to come and settle in Kenya. The result was that Kenya began to play the classic role of a country at the periphery of a capitalist system providing raw material exports for metropolitan manufactured goods.

The dominant concern of the colonial authorities during the first decades of their rule was the provision of good and cheap agricultural land for the settlers. Through their political domination, the settlers constructed an economy which would benefit them exclusively. Large areas of land were allocated for them by the colonial state; tribes such as the Kikuyu, the Maasai, and the Nandi had to give up land which previously had been under their control (GRI68: 63-67; GR105; GR156). The land was sold to the settlers on favorable terms. For example, in the Crown Land Ordinance of 1915, leases for 999 years were given out at very low prices. In the 1930's, the Carter Commission set aside nearly 17,000 square miles, or twenty percent of Kenya's best land, for exclusive White settlement (GR64: 87; GRT56: 34 ).

Despite the expropriation of land from the Africans, the settlers had a difficult time making their farming a profitable venture due to a lack of both knowledge and capital. This was the main cause of the 
enormous exploitation of labor that took place in Kenya; the settler farms had to have cheap wage labor to be economically viable. In addition, the settlers were cognizant of the fact that African peasant farmers, who worked for less money, who had lower personal consumption demands, and who used more labor-intensive techniques, could produce and sell at lower prices. If this situation were allowed to continue, African production would undercut European production in the product market, and, by offering an alternative source of cash income, drive up wage rates on European farms and plantations. Indeed, between 1912 and 1913. African production had accounted for at least $70 \%$ of exports GR105; GR99). This sentiment was clearly expressed by Lord Lugard in 1922:

The requirements of the settlers, to put it bluntly, are incompatible with the interests of the agricultural tribes, nor could they be otherwise than impatient of native development as a rival in the growing of coffee, flax, and sisal.

(GR108: 397)

To forestall or permanently prevent this competition, two specific strategies were developed by the colonial government. The first strategy was directed toward forcing Africans to work as laborers on European farms, partly by force, partly by taxation, and partly by preventing them from having access to enough land or profitable crops to enable them to pay the various taxes without working for wages (GR105: 10; GR22; GR170). In this fashion, a considerable supply of African labor was available for the benefit of European settlers. It has been estimated that in the mid-twenties, more than half of the able-bodied Luos and Kikuyus were employed on European farms (GRT05: 31), and in total 
about forty percent of all eligible males worked on European farms (GR168: 63-77).

The second strategy was directed toward increasing the monopoly power of the settlers through control of the main state agencies such as the marketing and regulatory boards, production committees, and credit institutions. Through control of the state, the settlers were able to manipulate the legal framework of colonial rule and to prohibit the Africans from growing cash crops and from establishing commercial enterprises. The system of racialist rules and regulations worked to guarantee highly differentiated access to resources and opportunities among Europeans, Asians, and Africans. The Coffee Plantation Regulation Ordinance of 1918, the Marketing of Native Produce Ordinance of 1935, and the Credit to Native Control Ordinance of 1903 and 1948, for example, were measures designed to restrict significant African participation in Kenya's political economy (GR73).

The infrastructural development also favored the settlers. The railway served the areas of White settlement, and different prices were charged for the shipment of European and African produce. The pricing of commodities also discriminated against the Africans (GR105; GR22). The tax system served to transfer money from the poor African areas to the wealthy White areas. Despite the fact that in 1920-23 Africans paid approximate1y $70 \%$ of al1 taxes in Kenya (GR22: 193), the Whites reaped nearly all the benefits of government services such as agricultural extension and credit. Given all these restrictive and discriminatory policies, it is no wonder that the European settlers dominated Kenya's colonial economy. This domination was not a function of the Europeans' productive 
efficiency nor their propensity to innovate. Their domination was the consequence of the prohibition by force of African competition as well as the exploitation of Africans in the production process.

Thus, early on, Kenya was characterized by a regulated and controlled economy. Far from operating in an open, competitive frontier economy where riches were to be seized by the bold and adventuresome, European settlers entered a political economy in which they were protected, nurtured, and fostered through their control of the State's power. These factors meant that Kenya was involved in a dependency relationship rather different from the simple staple export pattern; its dependency was characteristic of what Apollo Njonjo (GR117) refers to as "Apartheid capitalism," involving the dependence of dominant local forces (particularly the settlers) on the colonial state's resources and actions, which were significantiy--though not wholly--shaped outside Kenya (GR99: 20). Had access to resources and opportunities not been restricted, European dominance over African interests would have been impossible. The corresponding educational system also mirrored that same ideology which justified access to resources according to race and class. This restriction of access and formalization of privileges remains the principle of economic organization in Kenya at the present time.

The particular pattern of Kenya's incorporation into centers of metropolitan accumulation shaped the dialectics of African nationalist opposition, resulting in the emergence of the Mau Mau movement which militarily challenged European occupation of Kenya. The crisis which this movement generated led to a series of constitutional changes which preceded formal political independence (GR135; GR161). The 1954 Lytt1eton 
Constitution and the 1958 Lennox Boyd Constitution sought to establish the economic foundation of Black conservative rule in Kenya (GR140: 56-57). As a result, African participation in the legislative council was accelerated. The 1954 Swynnerton Plan introduced reforms into African agriculture for the first time. The plan called for the development of extension services in the African areas, permission to grow cash crops, access to credit, and land consolidation and registration. In short, these reforms attempted to introduce capitalist agriculture and commerce to African areas.

Despite the military defeat of the Mau Mau, African nationalism in this period succeeded in creating a ne'w political context in which successive colonial administrators accepted the urgent need for political and economic changes for Africans. This shift represented, however, simply an extension of privileges to very few educated Africans, particularly the kikuyus, who would cooperate with their formal colonial masters. The existence of an African petit bourgeoisie class facilitated the transition of the Kenyan political economy from colonialism to a neocolonial relationship, further tightening the links of dependence (GR161; GR22; GR105). The important question of structural transformation for the majority of Kenyans who had formed the most potent Mau llau base was put aside.

By 1963, Kenya inherited, along with independence, a very disintegrated political economy, already organized for the benefit of Europeans and those African petit bourgeoisie who came to dominate the State. With few exceptions, Europeans occupied the top brackets of the income scale, the Asians the middle, and the Africans the bottom. Inequality 
was deeply embedded within the society. The government's response to the existing dependency relationship has focused on Africanizing* the schools, businesses, the civil service, and commerce, thus keeping the major tenets of dependency intact. In the present context, such dependency distorts the relationship between the educational system and the economy and conditions manpower planning.

\section{Educational Policy in Colonial Kenya}

The economics and politics of European dominance in Kenya required an educational system that would enhance the privileged positions of the European settlers and the traditional elites (and hence their offsprings) who collaborated with the colonizers. To achieve that end, tremendous cooperation was required between the colonial administration, the missionaries, and the European settler class (GRI12; GRT40; GR142: 32-47). This symbiotic relationship, which lasted until the mid-1950's, had a tremendous impact on the development of education in Kenya and the present political-economic relationships within the country.

More than fifty years before the British incorporated Kenya as a protectorate, European missionaries of different denominations had already established schools to spread Christianity. The first mission school was established at Rabai, near Mombasa, in 1846, but little progress was made in establishing schools further inland until the contribution of a railway which enabled the missionaries to expand their evangelist

\footnotetext{
*Africanization refers to the process by which African governments attain national control of their economies, by replacing their own citizens with expatriats in the strategic areas of the economy'.
} 
activities (GR15: 12; GR112; GR142: 5). By 1906, fifty mission schools had been established in Kenya. This number reached 105 by 1916 (GR112: 119). Indeed, missionary influence remained the dominant force until the mid-1920's when it had to submit to the rule of colonial administration. Even then, the missions continued to operate their schools independently.

In 1909, the British Government commissioned a study of Education in British African territories. The Frazer Report recommended the establishment of education in British territories on a racial basis. The reason for this segregationist policy was summed up in the Beecher Report of 1949 which stated that

African education cannot be compared with education in European or Asian society . . . The peculiar nature of African education, with its limited achievements, is such that long-term planning alone is appropriate. We are only (with African education) at the state of establishing standards, while European and Asian educational systems are concerned with maintaining long and well established standards.

(GRI12: 132)

The argument supporting segregation is academic. The material reason for segregation was that the three racial groups of Kenya were being trained to maintain their respective social statuses. The Europeans were being trained to be the masters, the supervisors, the leaders; the Africans to be the servants, the laborers. Each had to be educated to take his place in society, not according to his ability, but according to his race. The context and purpose of education was set by occupation as well as by social and political limitations.

As a result of this policy, the educational systems were treated 
differently in terms of financial support. Financial provision for African education was not seen to be of vital importance and was, therefore, always considered in relation to the country's ability to pay. In 1925, the per capita cost of African education was $t 1 . \tilde{o}$, while the European cost was $t 41.6$; in 1931, the figures were $t 3.5$ and L42.6; and in 1935, t0.8 and $t 36.7$ respectively (GR112: 145). In the late $1940^{\prime}$ s, the African population was estimated to be at least three hundred times as large as the European, yet expenditures on education for the two races was almost equal; and in some years, the expenditure on European children was greater (GR66: 337 ).

\section{TABLE I}

ALLOCATION OF COLONIAL REVENUE ON EDUCATIOIN FOR THE DIFFERENT RACES, 1926-1949 IN $t$ 'S

\begin{tabular}{l} 
Year \\
\hline 1926 \\
1927 \\
1928 \\
1929 \\
1930 \\
1931 \\
1932 \\
1933 \\
1934 \\
1935 \\
1936 \\
1937 \\
1938 \\
1939 \\
1940 \\
1941 \\
1942 \\
1943 \\
1944 \\
1948 \\
1949
\end{tabular}

\begin{tabular}{c}
$\begin{array}{c}\text { African } \\
(92 \%)\end{array}$ \\
\hline 47,797 \\
52,431 \\
72,003 \\
74,131 \\
83,088 \\
82,823 \\
76,472 \\
70,594 \\
72,411 \\
74,097 \\
70,154 \\
77,793 \\
80,130 \\
81,869 \\
79,936 \\
75,030 \\
81,221 \\
75,118 \\
93,963 \\
211,953 \\
323,340
\end{tabular}

Indian

$(6 \%)$

14,471

17,318

22,963

25,603

30,582

34,348

32,371

41,675

33,818

34,060

37,341

39,140

43,861

45,602

48,094

48,327

49,820

52,040

63,647

137,313

206,969

$$
\begin{gathered}
\begin{array}{c}
\text { European } \\
(2 \%)
\end{array} \\
\hline 28,815 \\
36,032 \\
42,294 \\
49,360 \\
49,310 \\
49,189 \\
48,126 \\
42,400 \\
44,011 \\
44,041 \\
46,529 \\
49,255 \\
49,003 \\
51,881 \\
50,655 \\
54,338 \\
66,800 \\
87,845 \\
119,631 \\
207,622 \\
285,459
\end{gathered}
$$

Source: (GR112: 136) 
The distribution of educational resources and opportunities was also uneven among the three racial groups. From the early years of colonialism, education was compulsory for European children between the ages of 7 and 15 (GR85: 4). Education for Africans was not compu7sory until after the Second Horld War. The numbers of schools available, as well as the rate of enrollment for these three racial groups, differed markedly. While the Europeans had secondary schools as early as 1915 and Asians had them in nearly every major town where they had settied by 1923, the Africans opened their first secondary school in 1926 and only four secondary schools in the 1940's (GR81: 29; GR142: 50-68). In 1911, the Colonial authorities in Kenya took the first step towards what the missionaries considered an invasion into their domain by forming a Department of Education. The fear on the part of the missionaries that the government intended to take control over all education was strengthened when, in 1915, a State school for Africans was opened at Machakos (GR75: 150-151; GR112: 37; GR140: 73). The missionaries refused additional Government educational grants on the grounds that financial control was the first step towards a final takeover. Nevertheless, as the colonial authorities in Kenya and Britain began to take interest in education and the missionaries found it increasingly difficult to finance the school system on their own, a pattern of cooperation developed in which missions came to depend largely on governmental financial support. The State left the responsibility for supervision and management of the schools to the missionaries.

Initially, the Department of Education was concerned primarily with the education of European children. No serious thought was officially given 
at the outset to education for Africans. Shortly thereafter, however, the colonial administration and the settlers both recognized the need to educate Africans if economic sufficiency were to become a reality for the European community. The education of the Europeans and Indians provided the managerial and artisian classes of citizens. The education of the Africans was intended to provide a more productive menial class of workers. Therefore, cooperation among all European interests in Kenya was seen to be vital to the success of this undertaking. This initial agreement among the administration, the missionaries, and the settlers formed the starting point, and only later did disagreement arise regarding what form this education should take, what methods should be adopted, and to what extent it should be carried out.

Initial governmental interest in education for Africans was motivated by two needs: the need to make the colony self-sufficient and the need for an enlightened class of Africans to put into effect the British doctrine of "indirect rule." The settlers also needed an enlightened labor force, capable of taking instructions; and they turned to schools to provide it. The missionaries, on the other hand, wanted only to spread the teachings of the Bible in the quickest and most effective way and saw education as the easiest means of doing so. With the administration and the settlers entering the field, however, the missionaries were forced to extend their educational services to cover secular education and technical training for the economic development of the country. Thus, in 1919, a joint government-missionary-settler commission agreed that a minimal amount of academic education for Africans was necessary (GR140: 17). There was some fear in the European community that academic studies 
would discourage African children from becoming laborers. As a result of this fear, it was decided that only selected individual Africans should receive a general education and only to eleven years of age: any further education should be vocational. Deliberate preference was given to the children and close relatives of those recognized as traditional political leaders such as chiefs and representatives of local native councils in exchange for translating to the Africans the policy of indirect rule. In essence, the new policy created a stratified educational system within the African community (GR112: 59-61).

Although the different European groups wanted the Africans to be educated, soon the divergence of their aims and motives, the different interpretations given to education, and the differing goals became apparent. First, there was the major conflict between the Africans and the colonists regarding the role of education. The higher wages commanded by Africans who had been to school, their apparently favorable relationship with the colonists, and their generally higher status compared with their illiterate contemporaries all seemed to point to education as the secret of power and material progress. The Africans, therefore, not only rejected the restriction imposed on their educational advancement, but they also rejected an education tailored to keep them in subservience to the Europeans (GR103; GR140: 24).

Secondly, there were conflicts between the missionaries and the colonial administration as the former sought to keep their adherents from attending government schools by discrediting the staff in those schools on moral grounds. The latter, in turn, charged the missionaries with disrupting the African way of life. This was expressed in the 
circumcision controversy of the 1930's. Missionary control of primary schools and the missionaries' ambivalent stand on matters related to African traditions were to lead to the opening of Independent Schools, particularly among the Luos, the Kikuyus, and the Pokomos (GR7; GR140: 27; GR142: 149).

Thirdly, there was internal conflict created by the missionaries. They had, from the beginning, worked on the doctine of divide and conquer. Those Africans who accepted Christianity were able to receive preferential treatment in the field of education, while non-Christians were discriminated against. This, for all practical purposes, also meant preferential treatment in the labor market. This group of Africans included the sons of chiefs, the preachers, and the businessmen. This point must be stressed because the graduates of missionary schools (the collaborators of colonialism) are now the most influential people in the government; and by virtue of their position, they stand to gain from the present setting of economic development and have established a base from which their offspring will always benefit if the system remains unchanged (GR85).

Legal recognition of education in the colony came in 1924 with the legislative council's passage of the Education Ordinance. In theory, the 1924 Ordinance gave the right to inspection of schools to the Director of Education. Under the ordinance, missionary schools were recognized as voluntary agencies and became eligible for grants-in-aid (GR112: 89; 140; 142). Despite the ordinance, missionary influence on African education remained very strong until the time of independence. Prior to 1925, therefore, neither the officials in Kenya nor those 
in London had any clear idea of what should constitute education for Africans, apart from the fact that it should be geared towards economic development and hence self-sufficiency of the colony. Directives from the Colonial Office were vague and open to different interpretations. In many cases, the policy laid down did not meet practical circumstances and was frustrated by the conflicting interests of the administrators, the settlers, the missionaries, and later the Africans.

\section{Educational Policy After 1925}

In 1925, the British Colonial Office issued its first statement on African education. The 1925 Memorandum laid down the thirteen principles which became the basis of educational policy in all British African colonies for the next quarter of a century (GRI04: 13; 140). Drawing heavily from the 1924 Phelps-Stokes Report, which sought to develop the "right sort" of education for African children (i.e., vocational education), the memorandum initiated a process of experimentation aimed at adapting education to African life and cultural heritage. This position, maintained through WW II (and being perpetuated in the post-independence era), was interpreted as meaning education that would not overly stimulate the outside interests of rural African children; it would encourage them to remain farmers and not to seek other kinds of employment in urban centers (GR75: 150; GRI12: 59). Ironically, these views are expressed in the Report on Educational Goals and Objectives of 1976 and also in the 1979-83 Development Plans. In both instances, no serious program was pursued by the government to transform the social and economic conditions of Kenyans, particularly in agriculture. 
The 1925 Memorandum and those subsequent to it completely ignored the felt needs of the African community for equal access to resources and opportunities. The different racial groups were educated according to the social and occupational role their members were expected to play in national development. Apartheid capitalism in Kenya was also expected to survive indefinitely. The events of the fifties, particularly the Mau Mau struggle, were to shatter these assumptions.

As early as 1924, the African community had shown an awareness that colonial policy was designed to perpetuate their state of subservience to Europeans. They had also begun to question the imbalance between their contribution to colonial revenues and the social benefits that they received in return. For example, Direct Tax in the Nyanza Province showed an increase of 325\% between 1905 and 1910, whereas the nonAfrican revenue of the country in general showed a decrease of $12 \%$ (GR112: 134). Africans then began to express the view that part of their taxation should be earmarked specifically for the development of their own areas. The Education Ordinance of 1924 established an Advisory Committee on which Local ivative Councils were represented. Gradually, the idea that responsibility for primary education should rest in local hands became accepted. The Africans seized the opportunity offered by local native councils to tax themselves to finance education and to open up new schools in their respective communities (GR35; 165 ). The extent of local contribution is shown in Table II on the following page. 
TABLE II

LOCAL NATIVE COUNCILS EDUCATION EXPENDITURE:

IN SHILLINGS 1926-1931

\begin{tabular}{|c|c|c|c|c|c|c|}
\hline Council & 1926 & 1927 & 1928 & 1929 & 1930 & 1931 \\
\hline $\begin{array}{l}\text { NK } \\
\text { CK } \\
\text { S Lumbwa } \\
\text { Kiambu } \\
\text { Fort Hall } \\
\text { S Nyeri }\end{array}$ & $\begin{array}{c}20,000 \\
30,000 \\
2,200 \\
10,000 \\
-- \\
100\end{array}$ & $\begin{array}{c}40,000 \\
300 \\
-- \\
-- \\
100\end{array}$ & $\begin{array}{r}100,000 \\
110,000 \\
20,300 \\
120,000 \\
40,000 \\
600,100\end{array}$ & $\begin{array}{r}211,000 \\
213,894 \\
300 \\
120,500 \\
31,500 \\
100,500\end{array}$ & $\begin{array}{r}251,000 \\
244,770 \\
14,700 \\
112,900 \\
99,700 \\
150,500\end{array}$ & $\begin{array}{r}196,000 \\
32,096 \\
10,000 \\
57,000 \\
95,200 \\
160,500\end{array}$ \\
\hline Embu & 980 & -- & - & -- & - & -- \\
\hline Meru & -- & -- & 400 & 500 & 2,500 & -- \\
\hline Machakos & 24,000 & 22,500 & 16,880 & 21,000 & 1,000 & 19,000 \\
\hline $\begin{array}{l}\text { Taita } \\
\text { Kitui }\end{array}$ & $\begin{array}{r}100 \\
6,000\end{array}$ & $\begin{array}{r}200 \\
6,000\end{array}$ & $\overline{7,000}$ & $2 . \overline{000}$ & $-\overline{500}$ & $-\overline{0}$ \\
\hline Digo & -- & - & 1,000 & 3,200 & 3,200 & 3,000 \\
\hline Giriama & -- & -- & - & 21,000 & - & 500 \\
\hline Elgeyo & -- & -- & 3,000 & 37,600 & 16,700 & 15,420 \\
\hline Marakwet & -- & -- & 1,000 & 6,400 & 3,340 & 6,980 \\
\hline Nandi & 10,000 & 6,000 & 6,400 & 10,250 & 6,250 & 10,850 \\
\hline W Suk & -- & -- & -- & 2,000 & 13,000 & 10,000 \\
\hline Baringo & 2,000 & -- & -- & -- & -- & -- \\
\hline Kajiado & 20,000 & 30,000 & 22,500 & 40,100 & 31,300 & 34,335 \\
\hline
\end{tabular}

The decision to entrust Local Native Councils with the responsibility for primary education was calculated to shift the financial burden from the government. Although the Councils welcomed the idea as an opportunity to develop their own schools, by 1942, their financial situation was in desperate shape. Educational expenditures continued to rise to the detriment of other social services such as rural access roads, health services, and marketing facilities (GR112: 151).

From the 1920's until the mid-1940's, the institutional framework for the formulation and implementation of policies for African education included the joint participation of colonial administrators, missionaries, and European settlers. The colonial administrators repeatedly sought to 
free themselves from this burden, but political pressure by Africans for more rapid expansion forced them to accept responsibility after the Second World War. At this point, the old colonial policies of "self-sufficiency" and "trusteeship" were dropped and' "partnership" was substituted (GR129:7; GRT40). The British Government recognized the growing political role of Africans and began to create more of a progressive political situation in the colonies.

\section{Educational Policy After World War II}

After the War, the British policy began to change in the face of African nationalism. The British began to accept the idea that many British colonies would soon be independent (GRT12: 63; GRI29: 8; GRT40). In 1943, therefore, the Advisory Committee drew up a memorandum entitied Education for Citizenship in Africa, in which it was argued that mass education would be valuable only insofar as it trained young Africans to become responsible citizens of free countries. There is nothing to suggest that the intensified local educational activity of the late 1940 's and the early 1950's was the result of the recommendations of this committee. Rather, the activity could be more justifiably attributed to the changed local political condition in Kenya.

The 1948 Ten-Year Plan for education in Kenya (CG3) aimed to give $50 \%$ of school age children an education lastina 6 years and recommended that primary schools should be controlled by local authorities. Furthermore, the Plan called for local authorities to increase their expenditures for primary schools from $t 100,000$ in 1948 to $t 234,000$ in 1957 (GR129: 8). But the demand was such that further expansion of government schools was 
beyond the financial means of local authorities. Africans took this opportunity to begin to build their own schools using funds generated through individual contributions. The self-help efforts led to the emergence of a shadow school system, unregulated by the government. This system now accounts for $60 \%$ of the secondary school enroliment in the country (KG3, 1977). The central government felt increasingly uncomfortable about its inability to give the desired level of supervision and financial assistance to unaided schools (GR142: 148). This situation has remained unchanged and is the major headache of the postindependence government. In order to limit an influx of African pupils into upper primary and secondary schools, the government introduced a pyramid structure into African education which allowed a large number of pupils to enter primary schools and then progressively restricted opportunities as the students climbed the educational ladder through secondary school to the university. Each grade had to be passed in succession if a pupil were to proceed.

The Beecher Commission (1949) introduced a 4-4-4 system of primary, upper primary, and secondary schools to replace the previous 6-2-4 system. The Commission based its recommendations regarding educational structure on a $50 \%$ dropout rate. As soon as the dropout rate fell and more Africans remained in schools, examinations played an even more important role in limiting the numbers that ascended each successive rung on the educational ladder (GRT40: 41-43; GRT64:6). The grading of classes and schools and the provisions for expansion were based on the assumption that of the pupils who entered primary schools, $50 \%$ would drop out. In other words, for every 100 children entering 
primary school, only 8 would proceed to intermediate schools (upper primary), and only 2 would finally enter secondary schools (GR112: 110). The aim of this policy was clearly to limit the number of educated Africans who could qualify for the franchise, thereby preventing their influx into the labor market. The fear was that too many educated Africans would put pressure on the government and on employers to offer them occupations which had traditionally been held by Europeans; they also feared that a large reservoir of trained but unemployed Africans might lead to political unrest. In 1963, the combined result of dropout and examination failures appeared as presented in the table below.

\section{TABLE III}

WASTAGE AND RETENTION IN KENYAN SCHOOLS, 1963

\begin{tabular}{|c|c|c|c|}
\hline \multicolumn{2}{|r|}{ Primary School } & \multicolumn{2}{|r|}{ Secondary School } \\
\hline Year & Degree of Wastage (\%) & Year & Degree of Absorption (\%) \\
\hline $\begin{array}{l}I I \\
I I I \\
I V \\
V \\
V I \\
V I I-V I I I\end{array}$ & $\begin{array}{l}44 \frac{1}{2} \\
20 \\
14 \frac{1}{2} \\
10 \\
8 \frac{1}{2} \text { (Common Ex) } \\
7 \frac{1}{2} \\
\frac{2}{2}\end{array}$ & $\begin{array}{ll}\text { Jr } & \text { I } \\
& \text { II } \\
\text { Sr III } & \text { IV } \\
& V \\
& V I\end{array}$ & $\begin{array}{cc}44 & \\
38 & \text { (KAPE) } \\
5 & \\
3 \frac{1}{2} & \text { (KASE) } \\
1 & \\
\frac{1}{2} & \text { (School Cert } \\
\text { Univ Exam) }\end{array}$ \\
\hline
\end{tabular}

Note: Of those who finished their primary course, only $44 \%$ proceeded to the first year of secondary courses.

Source: (GRI12: 112)

It is not surprising that Africans opposed these recommendations which recognized the termination of education for half of the children after only four years of schooling (at the age of about ten). They felt justified in concluding that the Beecher Commission was designed to provide cheap, maleable, and constant labor in the form of eleven year olds, 
to the settler community. Thus, dissatisfied with the education provided by the missionaries and the negative response of the Beecher Committee to any of the African concerns, Africans sought, from their own pockets, to provide themselves with education. This gave rise to the Independent Schools Movement, the gravest reflection on the entire educational policy and a serious charge against the colonial government in Kenya.

Although many of the points stated in the Beecher Report were not implemented because of the Emergency, the planning and implementation of educational policy nevertheless remained isolated to a great extent from developments in other areas until the time of political independence. At the Lancaster House Conference of 1960, the central question raised by the colonial authorities was on what terms political independence would be granted to Africans. The most critical issue politically was the 1and question (GR105: GRI61; GR162). The aspirations of the African public were far-reaching. The solution should, therefore, at least satisfy the minimal expectations of the most land-hungry groups in Kenya. The British, on the other hand, were not willing to accept any takeover of 1 and by Africans without adequate compensation to the European settiers. UTtimately, an agreement was reached which satisfied both the Africans and the Europeans.

The essence of the agreement was that Africans buying land in the White Highland should pay for it with loans from the Kenyan government; the Kenyan government, in turn, was to obtain considerable sums of money (approximately $t 80$ million) from the British for this purpose (GR159; GRT61). The transfer of power could then take place in an orderly 
fashion, and the respect for private property would be upheld. The pattern of decolonization was, therefore, carefully influenced externally to detach that emerging African bourgeoisie class from the squatter wage worker radicalism of the Mau Mau. It led to much continuity in the regulative, restrictive, and unequal internal relations of the colonial past in Kenya (GR102: 41). The internal pattern of exchange relations, education, and the civil service was Africanized. Against a backdrop of dramatic political and economic activity, Kenya's educational system underwent a series of organizational changes, both before and after independence (GR87). The transfer of political power to Africans in 1963 did not bring fundamental changes in the economic, political, and educational structures of Kenya (GR87; GR105; GR162).

\section{African Reaction to Colonial Restrictions}

Although educational administrators in Kenya spent considerable time and effort on programs designed to adapt Western educational forms to their conception of African needs, they paid little attention to the integration of Africans into the new occupational structure except as adjuncts to positions held by Europeans. Until the pace of political development increased markedly in the mid-1950's, authorities tended to restrict the output of post-primary institutions to the immediate and visible needs for middle and low-level manpower. The priority for educational expansion, such as it was, focused on the spread of mass primary education with a vocational emphasis.

The African reaction to the colonial restrictions manifested itself in the form of independent churches, particularly in Western Kenya, while 
in Central Province, the African response to missionary control took the form of a revolt in the 1930's and subsequent establishment of independent schools (GR7; GR9; GR140: 27). Dissatisfied with mission education, the African community, particularly the Kikuyu of Central Kenya, began to organize themselves to establish their own independent schools. Christian missionary control of primary schools and the missionaries' ambivalent stand on matters related to African traditions (particularly the controversy surrounding circumcision), led to the opening of Independent Schools, particularly among the Luos and Kikuyus.

The vocational emphasis on African education was seen by the Kikuyu as a second-rate education designed to keep them as permanent laborers for the Europeans (GR129: 5). So far as the Kikuyu were concerned, the missionaries were apparently cooperating with the European settlers who were intent on alienating the land and forcing the Kikuyu into the role of a semirural labor force. As a result, the kikuyu were determined to boycott missionary education since it symbolized colonial oppression. The special situation of the Kikuyu and their close proximity to European settlements led to rapidly extending political concerns and also to a more sensitive appraisal of the political implications of education. According to Anderson, the Kikuyus

- . sought to create a generation of Africans sophisticated and able enough both to argue their case for self-determination and to demonstrate their competence to benefit by it, and thus obviate any resource to the violence latent in the colonial situation. 
In other words, the Kikuyus were aware of the importance of education for political emancipation. But more importantly, they were determined to excel in education so that they could control the political structures of the State at independence. The evidence presented in this study suggests that, after assuming leadership in 1963, the educated Africans (Luos and Kikuyus) have instead, ironically, contributed to the perpetuation of neocolonialism in Kenya. This raises the suspicion that personal interests of the Kikuyu-Luo-educated class dominated their desire to overthrow the colonial system. Recent political events in Kenya, particularly the imposition of a one-party State in May 1982 and the attempted subsequent coup, demonstrate in clear terms the determination of this educated political clique to subordinate Kenya's interests to the clique's own personal interests.

Although early African organizations such as the Kikuyu Association were formed at Government urging and served as a buffer between tribal grievances and the central government, those established later on were more instrumental in confronting colonial authorities on various issues (GR15: 119-122; GR96; GRI3G). For example, the Young Kikuyu Association, which was established in 1921, often confronted the authorities over issues of land, labor, and taxation. When its leader, Harry Thuku, was detained in 1922, the association was able to organize a massive demonstration of approximate1y 8,000 people (GR66: 279-281; GR135: 251). The Young Kikuyu Association was later named the Kikuyu Central Association (KCA) under the leadership of educated men such as Jomo Kenyatta. The reason that such educated Kenyans became the leaders of the independent struggle is explained by the fact that 
many of them were deprived of any meaningful role in the colonial structure. They therefore directed much political activity toward permanent opposition to established authority--European as well as the chiefs and elders who served as tools of European domination. In a similar fashion, the lack of any meaningful role for school Teavers in contemporary Kenyan society may lead to permanent opposition of the present government. In fact, in recent years, there have been many student strikes against the government, resulting in the frequent closure of the University of Nairobi (GR39; Weekly Review, March-August, 1982).

At the height of the Emergency in late 1952, the Kikuyu Independent Schools Association claimed over 400 schools, and the expansion came to an end when the government closed these schools for allegedly subversive activities (GR165: 7). In short, colonial educational policies and practices in Kenya did profoundly influence the nature of politics, acting as a catalyst in the growth of resistance to foreign domination and, more importantly, in the recruitment of elites committed to the achieverient of political independence.

\section{Summary}

The allocation of colonial State revenue, the ideological outlook and the skills imparted in each of the educational systems reflected the expected positions its products would occupy in the colonial hierarchy. African education was particularly geared to produce a better worker and a more useful servant to the Europeans. The combined effect of this policy was to reduce effectively the numbers of qualified Africans who would 
participate in the emerging modern industrial and commercial structure of the country. For example, in 1964, a Kenyan survey on high level manpower revealed how few Africans there were in the professions: 36 doctors, 20 electrical engineers, 17 university professors, and 7 economists $(K G: 11)$. Thus, by the time of independence, there were serious shortages of indigenous high- and middle-level manpower required for modernizing the economy. The developmental dilemmas which Kenya encountered at independence were simply the results of its position at the periphery of Western capitalism since the beginning of the nineteenth century.

\section{REAPING THE FRUIT OF "UHURU"}

\section{Educational Policy in Post-Independent Kenya, 1963-1980}

At independence in 1963, Kenya inherited a very disintegrated political economy, already organized for the benefit of European settlers. The entire setup of the political, economic, and social interaction was intended to reflect and to justify supposed racial differences and hence differential access to economic opportunities. The ILO Mission (GR69) estimated that by 1960, fewer than 4,000 European farmers owned approximately 3 million hectares of land, $4 / 5$ of the total area of the country having reliable rainfal1. Europeans dominated agricultural production completely.

During the same period, the average earnings of the 22,000 Europeans in wage-employment was more than $K \pm 1,300$ compared with those of 38,000 Asians of just over $K\lfloor 500$, and those of an estimated 530,000 Africans of Kt75 (GR69:91). The corresponding educational system also 
mirrored that same ideology which justified separate educational institutions for the three racial groups. The provision of elementary and secondary education on the eve of independence reflected a racial pattern which was characteristic of the colonial mode of development. The secondary schools were concentrated in the areas near European settlement and urban centers. In 1963, about 30\% of a 11 secondary schools in the country were in the urban areas, and these mainly catered to the Asians and European communities which formed about $3 \%$ of the total Kenyan population (GRB5: 4).

The table below indicates primary school enrollment on the eve of independence and reflects a similar racial pattern.

\section{TABLE IV}

PRIMARY SCHOOL ENROLLMENT BY RACIAL GROUPS 1963

\begin{tabular}{lrrrr} 
Racial Groups & \# of Pupils & \multicolumn{2}{c}{ Corresponding School-Age Pop. } \\
& & $\begin{array}{c}\text { Total \# of } \\
\text { Children }\end{array}$ & $\begin{array}{c}\% \text { of Pop. Child- } \\
\text { ren in School }\end{array}$ \\
\cline { 3 - 4 } African & 840,677 & $2,421,300$ & 34.7 \\
Arab & 3,322 & 9,000 & 36.9 \\
Asian & 40,915 & 52,800 & 77.5 \\
European & 6,639 & 8,900 & 74.6
\end{tabular}

Note: School age was estimated to be 5-14 years.

(KG7, 1965: 6)

While $75 \%$ of the European school age population was in school in 1963, the corresponding figure for Africans was only $35 \%$. Inequality was thus deeply embedded within the economy and the educational system. It was obvious that something had to be done in the immediate post- 
independence period.

Africanization of the political economy was the political answer to the problem. The ma in features of this strategy were formulated in the government document, African Socialism and its Application to Planning in Kenya (KGT), 1965. According to this document, the achievement of a rapid growth rate is the primary focus of government policy in Kenya. This approach to development made no attempt to restructure the political and economic institutions established in the country during the colonial period. Chief among these institutions is the educational system, with many of its coloniar legacies, such as the different school systems catering to the different social classes and the emphasis on academic criteria for advancement within the system. In fact, to a large extent, the educational system has remained the pillar of neocolonialism. Kenya's response to the inherited educational disparities involved (a) Africanizing enrollment in the schools, and (b) expanding access to opportunities by accelerating the supply of educational facilities. Rapid expansion was also justified for achieving a rapid rate of economic progress (KGT2; KG15). An impression of the educational expansion which followed independence can be gained from the following diagram which shows the level of primary and secondary schnol enrollments for the period 1961 to 1979. The figure shows that primary school enrollment jumped from 870,000 in 1961 to over 3.5 million in 1979. Secondary school enrollment reached 378,000 in 1979 from a mere 22,000 in 1961. Educational opportunities for girls, however, have tended to be lower at every level of education when compared with those of boys. The situation has improved tremendously with the passage of free education 
in 1974 for the first four years of primary school.

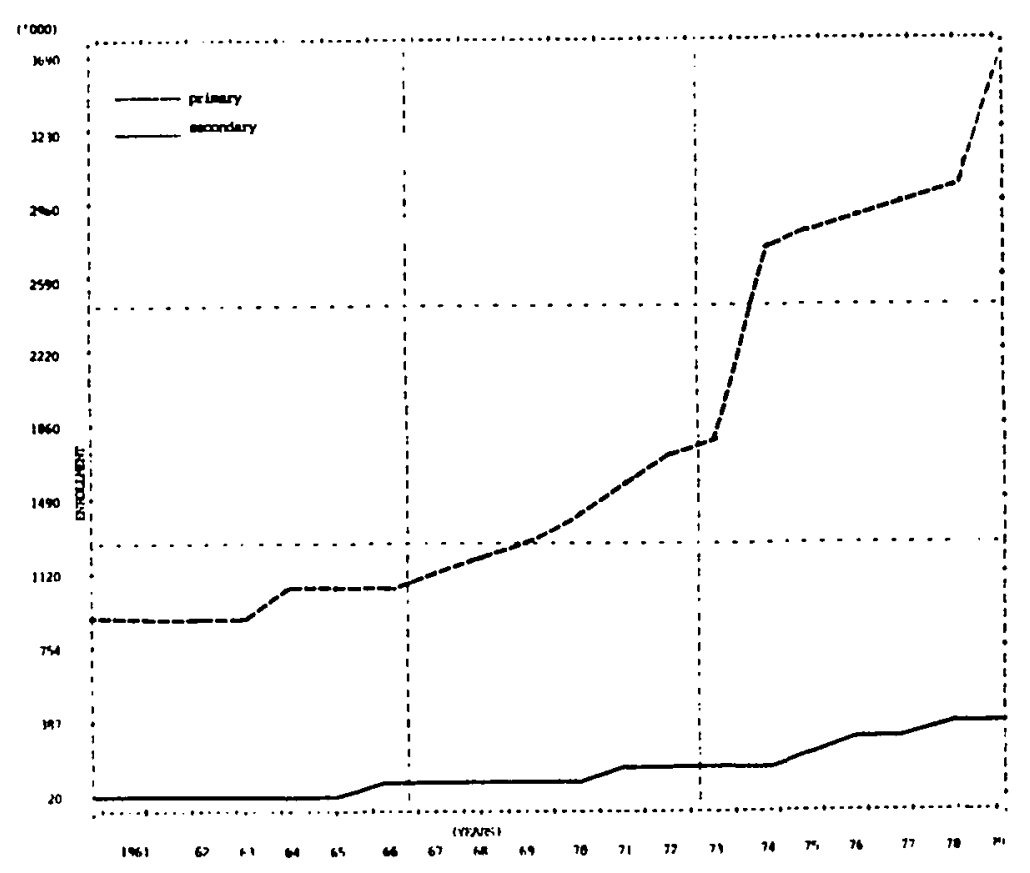

Figure 1. School Enrollments.

As a consequence of the rapid growth of enrollments following independence, government expenditures on education likewise increased rapidly and education's share of the governmental recurrent budget a7so increased, as indicated in Table V, on $\mathrm{p} \mathrm{63.} \mathrm{By} \mathrm{1976/77,} \mathrm{the}$ Ministry of Education was consuming close to $30 \%$ of the budget. As Nkinyangi (GRI18) explains, this pattern of expenditure attests not only to a high social demand for education, but is indicative of the faith the masses and policymakers ascribe to the role of education as a panacea for societal development. It also points out the serious impact that educational provision has on other recurrent expenditures. 


\section{TABLE $V$}

\begin{tabular}{|c|c|c|c|}
\hline \multicolumn{4}{|c|}{$\begin{array}{c}\text { APPROVED GOVERNMENT EXPEIIDITURE (NET) ONV EDUCATION } \\
\text { AS A PERCENTAGE OF TOTAL GOVERINMENT EXPENDITURE, } \\
1963 / 54 \text { TO } 1976 / 77 \text {, IN KE MILLIONS }\end{array}$} \\
\hline Year & $\begin{array}{l}\text { Next Recurrent } \\
\text { Expenditure on } \\
\text { Education }(a)\end{array}$ & $\begin{array}{l}\text { Total Gov't } \\
\text { Expenditure } \\
\text { (b) }\end{array}$ & $\begin{array}{l}\text { (a) as } \% \\
\text { of (b) }\end{array}$ \\
\hline $\begin{array}{l}1963 / 64 \\
1964 / 65 \\
1965 / 66 \\
1966 / 67 \\
1967 / 68 \\
1968 / 69 \\
1969 / 70 \\
1970 / 71 \\
1971 / 72 \\
1972 / 73 \\
1973 / 74 \\
1974 / 75 \\
1975 / 76 \\
1976 / 77\end{array}$ & $\begin{array}{r}8.3 \\
5.2 \\
6.8 \\
6.5 \\
7.6 \\
8.6 \\
15.7 \\
25.4 \\
31.3 \\
37.1 \\
38.9 \\
54.2 \\
64.6 \\
72.7\end{array}$ & $\begin{array}{r}42.6 \\
44.3 \\
49.7 \\
54.6 \\
58.8 \\
61.3 \\
73.9 \\
92.5 \\
109.5 \\
121.8 \\
146.1 \\
136.5 \\
228.6 \\
248.3\end{array}$ & $\begin{array}{l}19 \\
12 \\
14 \\
12 \\
13 \\
14 \\
21 \\
27 \\
29 \\
30 \\
27 \\
29 \\
28 \\
28\end{array}$ \\
\hline
\end{tabular}

(a) Totals in table are at current prices (not adjusted for inflation)

(b) Figures are not comparable for a 11 years. For instance, in 1970 the Central Government took over responsibility for financing primary education from County Councils.

(c) Figures for $1976 / 77$ are revised estimates.

* Expenditures financed by current receipt from internal borrowing and loan repayment receipts, direct and indirect taxation.

Source: (KG7)

Table VI summarizes the location of financial resources to the various educational systems in the country. Primary education continues to receive tine largest allocation, accounting for $58 \%$ of the total recurrent expenditure. This despite the insistence of the Kenya Education Commission (KG12) to assign greater urgency to secondary and postsecondary education to meet the manpower needs of the country. Secondary education received only $12 \%$ of the education budget in the 
$1978 / 79$ fiscal year. On the whole, the large expenditure on education attests to a high social demand for education and also reflects planners' and politicians' perceptions of the importance of education in development.

Within the Ministry of Education budget, expenditures are distributed as shown below.

TABLE VI

MINISTRY OF EDUCATION

ESTIMATES OF RECURRENT EXPENDITURE

$1978 / 79$

Kt' 000

\begin{tabular}{lrrr}
\multicolumn{1}{c}{ Education Section } & $\begin{array}{c}\text { Net Expendi- } \\
\text { ture in Kt's }\end{array}$ & $\begin{array}{r}\% \text { of } \\
\text { Total }\end{array}$ \\
Administration and Planning & $4,428.7$ & 4.3 \\
Primary Education & $59,740.1$ & 58.3 \\
Secondary Education & $13,003.4$ & 12.7 \\
Technical Education & $1,093.9$ & 1.1 \\
Teacher Education & $3,239.6$ & 3.2 \\
Education for Handicapped & 392.1 & 0.4 \\
Polytechnic Education & $1,542.0$ & 1.5 \\
Higher Education & $11,587.8$ & 11.3 \\
Miscellaneous & $7,338.1$ & 7.1 \\
\multicolumn{1}{c}{ Totals } & $102,329.7$ & 99.9 \\
& & &
\end{tabular}

Note: The table excludes expenditure on education by other ministries, notably on primary education in muricipalities and on adult education.

Source: (KG6, 1980: 178)

The basic characteristic of educational policy in postcolonial Kenya has, therefore, been the perpetual expansion of the school system as a means of redressing past disparities. From the point of view of a 
long term employment objective, the most damaging aspect of these events may be the effects of undifferentiated quantitative expansion on the educational system itself. As in the economy, basic structural changes were required in the educational system inherited from the colonial period. Yet the pressure of sheer expansion left little time for qualitative changes. Such expansion was supported by both young people and their parents who contributed enormous sums of money toward education. Thus, money and resources were channeled into a tremendous quantitative expansion of the system still largely cast within a colonial mold. Fundamental changes of structure, curriculum, examination and, indeed, the whole style and approach of the educational system were postponed. In a sense, the growth of the system and the Kenyanization of enrollments had prevented the educational structure from being adapted to national needs and made more equitable.

Despite the evident strides made in expanding educational opportunities, certain serious problems have emerged in recent years that deflect the country's educational goal and the reality of the economy: rising costs, educated unemployment, and regional disparities. This section will focus primarily on the distribution of educational resources and opportunities among regions and social groups and examine the extent to which such disparities have deflected the government's stated objectives of regional socioeconomic equity. Since education is viewed as a vehicle for social mobility, the analysis of educational inequality is fundamental to an explanation of the problem of unemployment in Kenya. 


\section{The Distribution of Educational Resources Since Independence}

Since independence, the government of Kenya has, in various documents, emphasized the need to distribute the fruits of development equitably. In Sessional Paper No. 10 (KG1), the official objectives were stated as: continued expansion of the economy, wider sharing of the benefits of expansion, national integration of the economy, and an attack on extreme imbalances and disparities. These objectives have subsequently been reflected in the country's four development plans pub1ished since independence $(1966-70 ; 1970-74 ; 1974-78 ; 1979-83)$. However, the development policies pursued so far have been limited, relative to the objectives these policies were intended to attain. In fact, they have produced results which often have reinforced the existing class and regional differences characteristic of the colonial mode of development (GR17; GR69). The ILO Report speaks of these disparities:

Differential access on a regional basis to such advantages as roads, education, and development projects is closely related to economic disparity, and is thus a major force behind migration, both from the country to the towns and from one rural area to another. Particularly serious is the way in which regional imbalances interact with tribal fears and forces, partly as a cause and partiy as a result.

(GR69: 301)

The disparities described above are particularly expressed in the provision of educational opportunities at the regional level. Gross disparaties remain between provinces and districts in such areas as the proportion of the primary age group actually in school, distribution of qualified teachers, distribution of secondary schools, etc (GR85). Although the disparities had their roots in the colonial political economy, 
they have been intensified by the development policies of the postindependence government. The disparities not only affect the structure and nature of the educational system, but also have a strong bearing on such issues as social mobility, income distribution, and social differentiation.

Primary School Enrollment. The outstanding feature of Kenyan education since independence has been the rate of expansion. As indicated in Table VII, primary school enrollment jumped from one million in 1965 to nearly 3 mission in 1978. However, access to primary education is unevenly distributed. The overall enrollment ratio (of the official 6 to 12 age group) in 1978 was $81 \%$. Provincial enrollment ratios ranged from $101 \%$ for Central Province, $99 \%$ for Eastern, $89 \%$ for Western, and $73 \%$ for Nairobi to $56 \%$ for Coast and $11 \%$ for North Eastern Province.

\section{TABLE VII}

PRIMARY SCHOOL ENROLLMENT 1965-78 AS A PERCENTAGE OF THE PROJECTED

SCHOOL AGE POPULATION (6-13)

1965

Province

Central

Coast

Eastern

$N$ Eastern

Nyanza

R Valley

Western

Nairobi

Kenya
$\%$ of Pop. Aged 6-13

68

33

52

2

36

35

51

57

45

$\begin{array}{rrr}\begin{array}{cc}1978 \\ \text { Enrollment }\end{array} & & \begin{array}{c}\% \\ \text { Aged of } 6-13\end{array} \\ 615,000 & & 100.8 \\ 170,000 & & 56.4 \\ 601,000 & & 99.3 \\ 9,000 & & 10.8 \\ 498,000 & & 68.0 \\ 570,000 & & 75.4 \\ 415,000 & & 89.0 \\ 90,000 & & 72.6 \\ 2,976,900 & & 81.0\end{array}$

Source: (KG8; KG7: 1979) 
The four provinces (Central, Eastern, Western, and Nairobi) had a headstart in Western education because of missionary activity in the early days of colonialism. And since independence, these four provinces have been very active in lobbying for central government resources. The same cannot be said about North Eastern and Coast Provinces which are lagging well behind because of geographical and historical circumstances. Traditionally, the predominance of Islam in these two provinces restricted missionary expansion, resulting in a delay in Western education reaching them.

The national figures on access to primary education hide sizable provincial differences. On the basis of data put together by Kinyanjui (GR86) and presented in Table VIII, there are indeed substantial disparities among provinces and districts. The explanation for these disparities is partly historical and partly due to a combination of political and economic factors. Historical factors include early missionary activity, particularly in Central and Western Provinces, a strong tradition of self-help in the former African Reserves, and the development of export agriculture, notably, coffee and tea in the former White Highlands. Most of the privileged districts had a head start in Western education because of a combination of these historical and economic factors and have managed to maintain their lead in the post-independence period because of their economic and political power.

In contrast to the high participating districts, there are many districts with lower participation rates. These include districts in Coast Province where resistance to missionary evangelism and the prevalence of Islamic schools prevented the spread of Western educational 


\section{TABLE VIII}

THE PROPORTION OF SCHOOL AGE CHILDREN (6-13) ENROLLED IN PRIMARY SCHOOL BY DISTRICT, 1971 AND 1975

\# of Children in School as a Proportion of Projected 6-13 School Age Population, 1971-1975

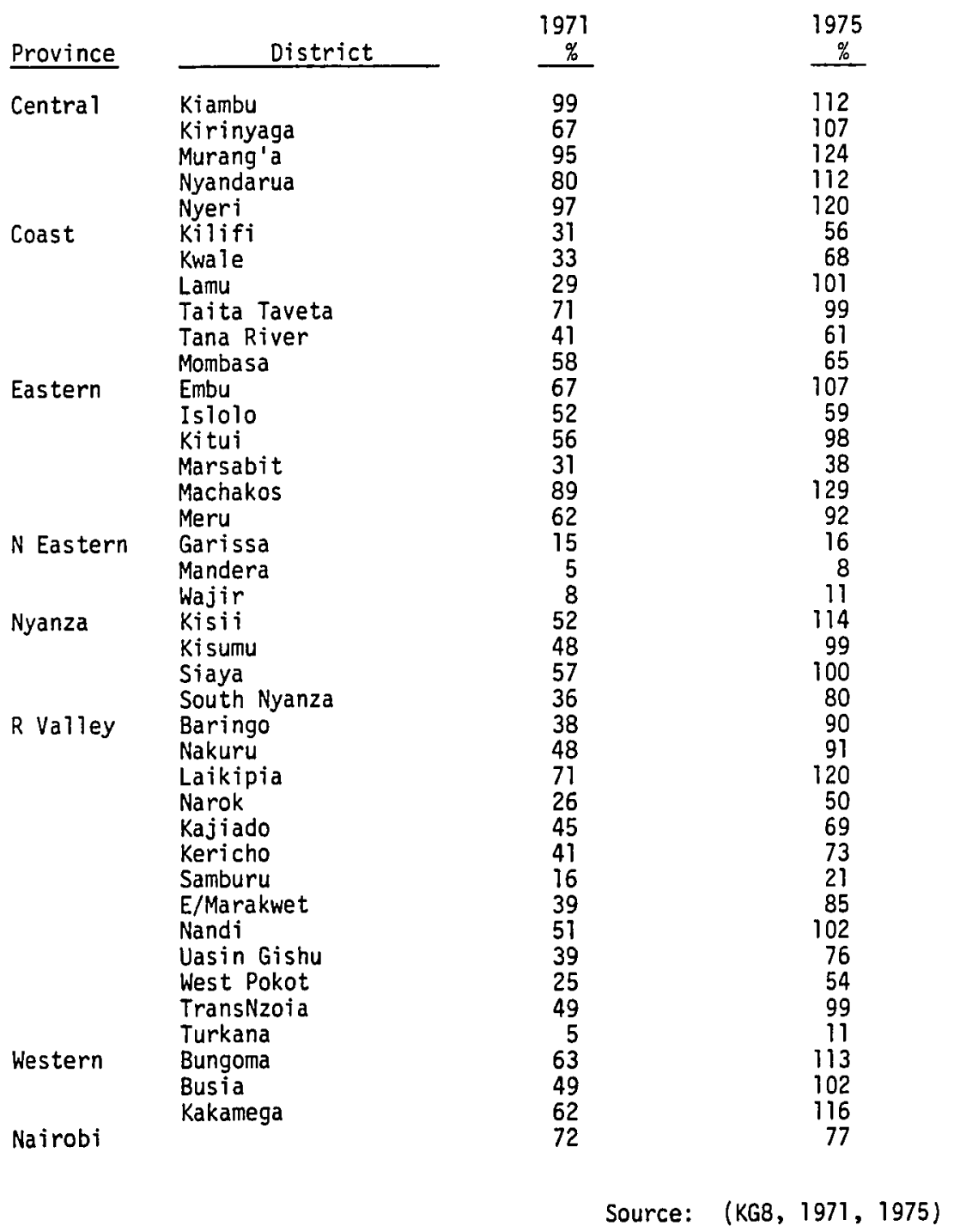


forms. Included also are the arid and semi-arid districts, mostly inhabited by pastoralists, and the four main urban centers of Kenya: Nairobi, Mombasa, Kisumu, and Nakuru. The explanation for the low participation in urban centers is a simple one. While participation is universal among high and medium income groups, it may well be very low among the urban poor and the unemployed. The rising urban squatter settlement in these towns points to this likelihood.

Distribution of Qualified Teachers. The shortage of qualified teachers has been a common problem of developing countries since independence. Generally, Kenya has done well in comparison with other African countries. In 1979 , nearly $75 \%$ of the primary teacher force was trained to teach, $37 \%$ of which had four years of high school plus two years of teacher training (KG6, 1980: 183). But the distribution of qualified teachers among the various provinces is extremely uneven. As shown in Table IX, $99 \%$ of the primary school teachers in Nairobi (for 1978) were professionally qualified, followed by Central Province, which 1 isted $87 \%$ of its primary school teachers as professionally qualified. The coast Province, with only 59\% of its teachers trained, ranked last on the list. The largest number of trained teachers was found in the Central, Eastern, and Rift Valley provinces, and the least number of untrained teachers was in Nairobi. The explanation for Central Province and Nairobi's share of qualified teachers is partly historical and partly due to a combination of political and economic factors. Proximity to the enclaves of European settlement and the urban center of Nairobi, the early missionary activity and a strong tradition of self-help are some of the historical factors which account for Central 
TABLE IX

PERCENTAGE OF QUALIFIED PRIMARY SCHOOL TEACHERS IN

EACH PROVINCE, FOR SELECTED YEARS

\begin{tabular}{|c|c|c|c|c|c|}
\hline \multirow[t]{2}{*}{ Province } & 1974 & 1976 & 1978 & \multicolumn{2}{|c|}{ Absolute Numbers of Teachers } \\
\hline & $\%$ & $\%$ & $\%$ & TRAINED & UINTRAINED \\
\hline Nairobi & 97 & 98 & 99 & 2,935 & 35 \\
\hline Central & 81 & 82 & 87 & 14,911 & 2,132 \\
\hline N Eastern & 71 & 61 & 64 & 225 & 127 \\
\hline Nyanza & 64 & 55 & 64 & 10,800 & 6,088 \\
\hline R Valley & 64 & 59 & 65 & 11,247 & 5,948 \\
\hline Eastern & 61 & 59 & 65 & 12,057 & 6,754 \\
\hline Western & 59 & 57 & 63 & 8,415 & 4,962 \\
\hline Coast & 57 & 53 & 59 & 3,372 & 2,416 \\
\hline Totals & & & & 63,912 & 28,134 \\
\hline & & & & $\begin{array}{l}\text { (KG7, } \\
\text { KG8, }\end{array}$ & $\begin{array}{l}1974,1976,1978 ; \\
1974,1976,1978)\end{array}$ \\
\hline
\end{tabular}

Province's lead in education. Nairobi's position at the seat of qovernment ard industrial establishment, and a large European community, explain its lead in education. Therefore, there is a clear tendency for the relative position of the disadvantaged provinces (Coast, North Eastern, and Rift Valley Provinces) to have worsened over time while the privileged provinces have maintained their lead. The pattern is expected to be the same in the provision of secondary school resources and opportunities. Distribution of Secondary School Resources.

(a) Secondary Schoor Expansion. At the time of independence, the government of Kenya was committed to as large a secondary expansion as it could afford because there was actually a shortage of students sufficiently qualified to replace the departing expatriates. Rapid expansion 
was also justified to provide a sufficient number of secondary schools for a large number of primary school graduates.

One of the best indicators of secondary school expansion is the immediate success of Harambee, or self-help schools, which were initiated on the basis of a felt need within each community for additional educational opportunities. Since 1967, Harambee schools have been the expanding edge of Kenya's secondary school system. Figure 2 , following, illustrates the extent of the expansion. For example, in 1966 there were 206 government-maintained schools and 336 Harambee secondary schools. In 1977, the corresponding figures were 444 and 1042, respectively.

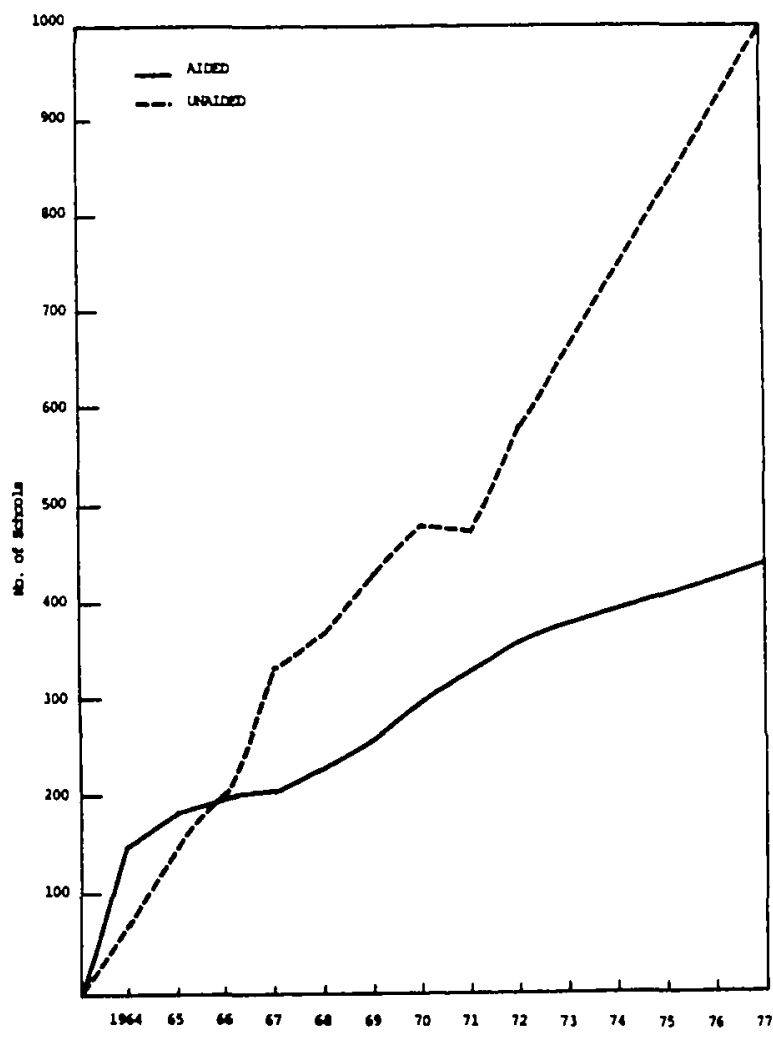

Figure 2. Secondary School Expansion, 1964-77 
The Harambee school system is not under the jurisdiction of the government. The Ministry of Education has little to do with this school system other than to certify its existence. Initially, these self-help initiatives were welcomed by the authorities as a sign of the new modernizing spirit by the majority of kenyans. In recent years, however, this uncontrolled expansion of Harambee schools has done much to destabilize any government effort toward a balanced approach to educational development in the country (GR81). The following have been the unhappy consequences of this rapid spread: (1) qualified teachers in Harambee schools are in short supply; (2) standards of curricula are uneven, and it is often hard to control the enforcement of certain minimum requirements; (3) the growing demand for academic schooling by the different ethnic groups hinders balanced national educational planning as the richer districts maintain their lead by building more schools and hiring the qualified teachers away from the deprived districts.

(b) Secondary School Enroliment. Secondary education, like primary education, at the time of independence consisted of three separate, racially divided systems in which Africans made up about $37 \%$ of the total student body (GR75: 154). In 1963, about 30\% of al1 secondary schools were in the urban areas, cacering to the Asian and European communities which formed only $3 \%$ of the total Kenyan population (GR85: 4). In a more determined step in 1967, the government directed that $50 \%$ of all entering students must be Africans; and that year, the overall proportion of Africans in secondary schools reached 82\% (GR75: 154). The trend continued; and by the mid-1970's, the vast majority of students were Africans, although some so-called "high-cost" schools still included. 
substantial percentages of non-Africans.

Progress in secondary education may be judged by the fact that secondary enroliments increased almost ten fold in a period of thirteen years (see Figure 3 , below), from 35,921 in 1964 to 320,000 in 1977. Harambee schools accounted for $60 \%$ of the total secondary school enrollment in 1977, which implies that a high proportion of the country's secondary school students were being trained in institutions of low curricular quality, inferior in equipment, and inadequate in terms of teaching staff.

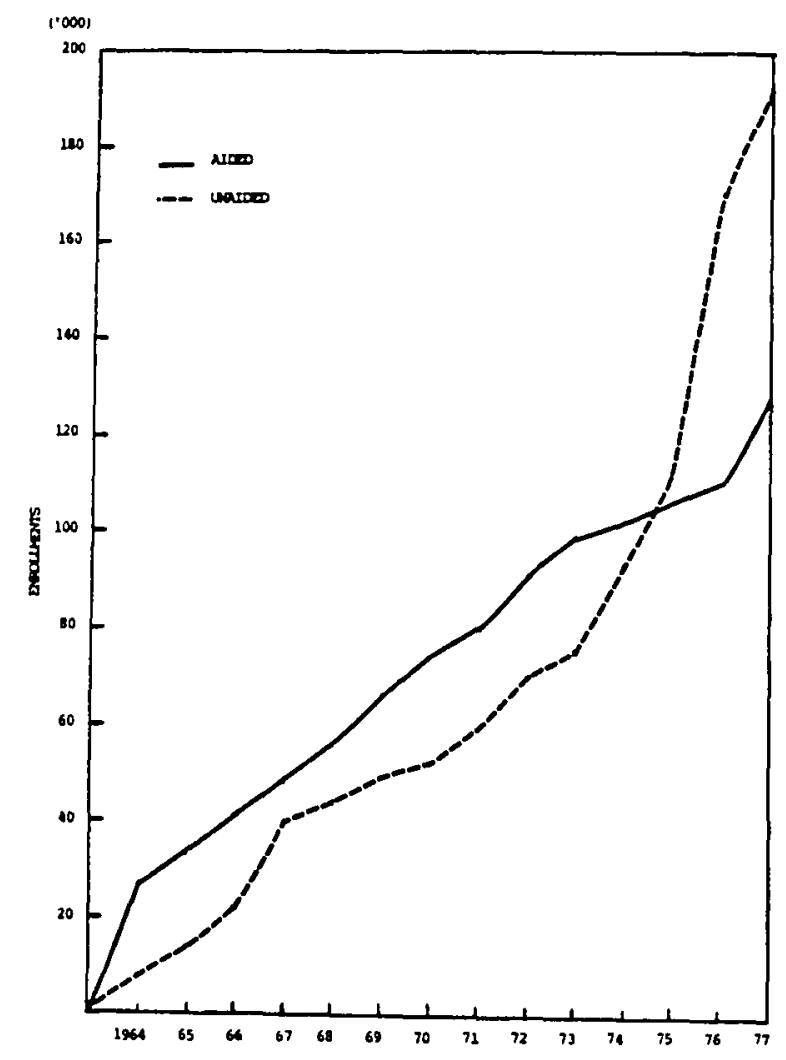

Figure 3. Secondary School Enrollments 
The low standard of education at the Harambee schools was shown to have a significant negative impact on the employment prospects of graduates from these schools. Kinyanjui (GR88), for example, reported that of the 1,186 secondary school leavers he traced, $37 \%$ of the Harambee school leavers were unemployed in their first year after leaving school. The corresponding figures for aided national and provincial schools were $6 \%$ and $5 \%$, respectively. This evidence suggests that the different school systems in Kenya are having differential social impact.

(c) Allocation of Public Funds for Secondary Education. Since so little data are available on the provincial allocation of government expenditures for education, it may also be of some interest to see how capital expenditures are allocated (even though this type of expenditure is small compared with recurrent expenditures). Only data for secondary schools are available (see Table $X$, below).

\section{TABLE $X$}

PER CAPITA DEVELOPMENT EXPENDITURE ON SECONDARY

EDUCATION BY PROVINCE 1974-78 (KL)

$\begin{array}{ll}\text { Nairobi } & 0.31 \\ \text { Central } & 0.53 \\ \text { Coast } & 0.25 \\ \text { Eastern } & 0.20 \\ \text { North Eastern } & 0.20 \\ \text { Nyanza } & 0.15 \\ \text { Rift Valley } & 0.19 \\ \text { Western } & 0.23\end{array}$

Source: This table is taken from Bigsten (GR17), who made his calculations from Development Estimates. 1974/751975/76 figures concern approved expenditures; $1977 / 78$ data concern estimated expenditures. 
Because these data indicate where new schools are built and where old ones expanded, one might expect the biggest share to go to the provinces, where the largest increase in enrollment has occurred. The Central Province had the largest increase in enrollment and also the largest share of development expenditures--actually more than twice what it would have received had the money been distributed on a percentage basis according to population size. Nairobi and the Coast have also obtained considerable sums, despite the fact that the number of pupils enrolled there has increased slowly. This is probably due to the fact that old, established, high-quality schools are well provided for. The Nyanza Province gets the least money per capita in development expenditures.

These partial data seem to support Nyangira's (GRI21) hypothes is that the money tends to flow to the most developed regions. Kinyanjui (GR85: 39) also concludes from his study that educational benefits are being distributed in favor of the economically and politically powerful districts and provinces in the country. In the context of this study, one important qualification must be made: although the distribution of educational expenditures among provinces reflects inequalities, they are still considerably more evenly distributed than economic activity in general (see Appendix A). They can, therefore, to some extent be assumed to counterbalance the regional disparities generated by the production apparatus.

(d) Distribution of Secondary Schools. In the past eighteen years, Kenya has achieved tremendous expansion in education, but regional inequalities have remained intact, and in some cases, have worsened. The 
distribution of secondary school institutions in 1977, shown in Table $X I$, illustrates once again the disparities which exist among the provinces.

TABLE XI

REGIONAL DISTRIBUTION OF SECONDARY SCHOOLS, 1977

\begin{tabular}{|c|c|c|c|c|c|c|}
\hline Province & $\begin{array}{l}\% \text { of Nat'1 } \\
\text { Pop. (1969) }\end{array}$ & $\begin{array}{c}\text { Aidec } \\
\# \\
\end{array}$ & $\begin{array}{c}\text { Schools } \\
\% \\
\end{array}$ & $\begin{array}{c}\text { Unaide } \\
\# \\
\end{array}$ & $\begin{array}{c}\text { Schools } \\
\%\end{array}$ & $\begin{array}{c}\text { Total } \\
\%\end{array}$ \\
\hline Central & 15.3 & 101 & 22 & 275 & 26 & 24 \\
\hline Coast & 8.7 & 31 & 7 & 40 & 4 & 6 \\
\hline Eastern & 17.4 & 76 & 17 & 198 & 19 & 18 \\
\hline Nairobi & 4.7 & 30 & 7 & 29 & 2 & 5 \\
\hline $\mathrm{N}$ Eastern & 2.2 & 4 & - & 0 & - & 0 \\
\hline Nyanza & 19.4 & 80 & 18 & 170 & 16 & 17 \\
\hline R Valley & 20.2 & 62 & 14 & 126 & 12 & 13 \\
\hline Uestern & 12.2 & 60 & 13 & 204 & 19 & 16 \\
\hline Totals & 100.0 & 444 & 100 & 1,042 & 100 & 100 \\
\hline
\end{tabular}

Source: (KG8, 1977)

According to the figures, Central Province, with less than $15 \%$ of the national population, contained $22 \%$ of the aided schools and $26 \%$ of the unaided schools, with a total of $24 \%$ of the secondary schools in the country. The explanation for Central Province's large share of educational institutions is partly historical and partly due to a combination of political and economic factors. Historical factors include the proximity of the province to the enclaves of European settlement and the urban center of Nairobi, early missionary activity, and a strong tradition of self-help in education, exemplified by the Kikuyu Independent Schools Movement of the early 1930's. The agricultural development 
of the area, primarily in the White Highland, and the political dominance of its residents (notably the Kikuyu) have also helped to consolidate this lead.

The province with the second largest provision of secondary school institutions was Eastern, with 18\% of the total secondary institutions in the country. Nyanza Province had the third highest percentage of secondary schools in the nation, with 17 . Western Province had $16 \%$. These four provinces had a head start in Western education because of missionary activities in the early days of colonialism. Since independence, these four provinces have been very active and sometimes very successful in lobbying for central government resources, in contrast to North Eastern, Coast, and some of the districts in Rift Valley Province. Although people in these areas are becoming aware of the disparities in education, they must contend with political and economic difficulties if they are to catch up. The urban areas, by comparison, are relatively well endowed with secondary schools. Nairobi, for instance, contained $5 \%$ of al1 secondary institutions in 1977, although the figure does not include the elite, privately-owned schools.

(e) Distribution of Secondary School Teachers. Secondary schools in Kenya are also very short of qualified teachers. As a result, the government has sought technical assistance personnel from friendly foreign countries in the form of trained teachers to overcome the existing shortages. As Table XII shows, this noncitizen assistance has been significant. For example, in 1970, 35\% of the technical assistants in the country were working for the Ministry of Education (GRI29: 30). In addition to expatriate teachers who are supplied to the givernment 
through bilateral aid, there are also volunteer teachers serving secondary schools in Kenya.

TABLE XII

DISTRIBUTION OF QUALIFIED SECONDARY SCHOOL TEACHERS BY PROVINCE AND CITIZENSHIP, 1977

\begin{tabular}{|c|c|c|c|c|c|c|}
\hline \multirow[b]{2}{*}{ Province } & \multicolumn{3}{|c|}{ Aided Schools } & \multicolumn{3}{|c|}{ Unaided Schools } \\
\hline & Citizen & $\begin{array}{c}\text { Non- } \\
\text { Citizen }\end{array}$ & Total & Citizen & $\begin{array}{c}\text { Non- } \\
\text { Citizen } \\
\end{array}$ & Total \\
\hline Central & 943 & 279 & 1,222 & 290 & 241 & 531 \\
\hline Coast & 243 & 121 & 364 & 42 & 105 & 147 \\
\hline Eastern & 551 & 125 & 676 & 221 & 121 & 342 \\
\hline Nairobi & 454 & 252 & 706 & 34 & 166 & 200 \\
\hline$N$ Eastern & 24 & -- & 24 & -- & -- & -- \\
\hline Nyanza & 590 & 122 & 712 & 150 & 95 & 245 \\
\hline R Valley & 496 & 145 & 641 & 126 & 125 & 251 \\
\hline Western & 442 & 44 & 486 & 68 & 112 & 180 \\
\hline Totals & 3,743 & 1,088 & 4,831 & 931 & 965 & 1,896 \\
\hline
\end{tabular}

Of the total of 6,727 professionally qualified teachers in Kenyan secondary schools in $1977,72 \%$ were located in aided schools, while only $28 \%$ were employed in Harambee and other unaided schools. In 1970 , $82 \%$ taught in aided schools, while only $18 \%$ were employed in Harambee schools (GR85: 35). In 1977, Central Province had 26\% of all qualified secondary school teachers. The province with the second largest provision was Eastern with 15\%; Nyanza, Rift Valley, and the city of Nairobi had $14 \%, 13 \%$, and $13 \%$, respectively. This again indicates the existence of long-established regional differences which had roots in the colonial period and which were accentuated in the post-independence era. 
The citizenship profile of secondary school teachers indicates that nearly $31 \%$ of the qualified teachers in secondary schools are noncitizens. Noncitizens account for $22 \%$ of the qualified teachers in aided schools and $50 \%$ of the qualified teachers in unaided schools. In the city of Nairobi, noncitizens make up $83 \%$ of the qualified teachers in unaided schools. This is an indication that a high proportion of the private, elite schools are concentrated in Nairobi, catering to the ruling classes.

The Harambee School as a Shadow System of Education

The Harambee School Movement, which gained momentum in the postindependence era, had its roots in the colonial period as exemplified by the Kikuyu Independent Schools Movement discussed in a previous section. A Harambee school is usually initiated on the basis of a perceived need within a community for greater educational opportunity for its children. The people of a community raise the funds for their schoors; they lend their labor for its construction; and they, most often without any governmental assistance, maintain the schools over time with the hope that the government will eventually step in and begin to materially support them.

Despite an initial government stand on the 1964 Kenya Education Commission (KG12) recommendation that Harambee schools be strictly controlied, there has been a gradual swing towards accommodating them. In the 1970 's and 1980's, politicians began to offer substantial support for these projects (GRT6; GR81; GR129). It is commonplace for politicians of national prominence to become involved with school movements. A 
great deal of importance is placed upon the participation of members of parliament and local government officials. This decision was, however, calculated to shift the financial burden from the government's shoulders while the different communities welcomed it as an opportunity to take a greater role in the education of their children.

In order to understand this apparent contradiction between stated objective and actual policy choice, one must place Kenya's national development policy in perspective. Kenya is committed to an overall development strategy which emphasizes gross economic growth, even at the expense of social equity when necessary (KGI: 18 ). This commitment underlies whatever other national choices are made. In a patron-client state such as Kenya, political choices are more often made which may not appear to make sense in strict economic terms, but which are nevertheless believed to enhance the attainment of broad economic goals. Often, social policies are adopted mainly because of the social-symbolic functions they serve and not because they distribute "the most good to the greatest number of people" (GR16: 101).

The policy of endorsing unrestrained expansion of secondary education, in particular the Harambee schools which are below recognized standards, can only be understood when political payoffs are considered. The growing number of Harambee schools has been complemented by an escalating demand from the general public that the government reward their efforts by relieving them of the tremendous financial burdens involved in sustaining such institutions. Through local patrons such as chiefs, elders, and KANU party officials and through their representatives in Parliament, local communities make demands upon the government to 
contribute to the support of their schools. The government's response to public demand has been to incorporate 25 to 30 Harambee schools annually into the "aided" system. In addition, the government instituted a scheme of aid to the Harambee secondary schools in 1975 entitled the "Harambee Package Programme" (KG4: 420). Under this plan, fifty schools are offered government aid in the form of fully qualified teachers, audio visual equipment, and annual assistance from the Inspectorate.

If a particular community lags considerably behind in education, the blame is always passed to the local representative, who is considered ineffective and is subsequently voted out of office. Consequently, community dissatisfaction is directed toward the local government representative (or patron) rather than toward the national political elite in Nairobi. Thus, by its political-economic balancing act, the government of Kenya is able to satisfy many demands and present the image of satisfying several others (GR16; GR122). As a result, an aura of stability and progress emerges which creates a climate favorable to sustained economic growth. In reality, however, the practice of selective incorporation of Harambee schools into the aided school system represents a token response from the government in that schools are expanding so rapidly that the present rate of supplying teachers or taking over schools is not sufficient to insure that the secondary system will be unitary in the near future (GR38). The merit of this paternalistic policy is not so much the tangible effect it has, but its symbolic effects. By presenting the image of doing something for the people, the government is able to elicit support for its policies, however 
limited their effect may be.

Local and national politicians justify the existence of the Harambee schools on the basis of political considerations. They express the view that unless the people are allowed to have their own schools, political unrest could develop. What these politicians ignore, however, is that the current school phenomenon exacerbates existing regional, ethnic, and class inequalities, which would have a devastating effect on the course of general national development. In addition, the fact that Harambee schools are only symbolically linked to the total educational system, education inspectors could not effectively monitor the activities of these schools. What results is a very imperfect attempt by the government to determine the direction of educational policy in the country.

In the final analysis, the evidence presented in this chapter leads to the conclusion that the development policies adopted by Kenya since independence did not lead to structural changes per se. Instead, the government devoted large sums of resources to education under the assumption that such an investment would lead to development. The impact of this misguided strategy on employment will be discussed in Chapter IV.

Summary

In the colonial period, the role and extent of education for Africans was dictated by the differing interests of 213 the communities who played a part in the formulation of educational policies, but even more by those who directly controlled it. The missionaries, the 
administration, and the Europeans formed a limited partnership. Later, the Africans became a fourth force; and when they failed to be recognized, they established their own schools outside the officiallyrecognized educational system.

The sharp inequalities among the three racial groups in the economic, political, and educational arenas became a major catalyst for the Mau Mau uprising in the early 1950's. The rise of African nationalism in this period succeeded in creating a new political context in which successive colonial Secretaries accepted the urgent need for political and economic changes in the African community. Important though these changes were, the underlying philosophy concerning development since independence was largely unchanged. The pattern of decolonization was carefully controlled to bring to power an African petty bourgeoisie class fully committed to the maintenance of the status quo, thus perpetuating neocolonialism in all aspects of Kenyan society. Structural transformation of the Socialist type was ruled out from Independence Government policy. Instead, Africanization of the political economy became the hallmark of Kenya's development policy after independence was achieved. In the educational field, this meant integrating a small segment of Africans into the former colonial institutions, thereby altering the racial composition of the schools without fundamental change to the structure of the educational system as a whole.

The political and social forces which existed during the colonial period have changed somewhat with time. But, by and large, they shaped the development of education and particularly the inequalities which 
occurred during the colonial period, some of which have persisted during the twenty years since independence. Indeed, some of the developments of the colonial period, such as self-help, the Harambee schools, and the use of examinations as a criterion for advancement, have gained momentum since independence. Thus, some of the dependency relationship has remained strong even though political independence has been achieved. This relationship has, however, been modified by the development strategies currently being applied in Kenya. 


\section{CHAPTER III}

\section{KENYA'S ECONOMIC DEVELOPMENT IN PERSPECTIVE: PITFALLS IN PAST AND PRESENT DEVELOPMENT POLICIES}

This chapter examines the relationship between the private and public sectors of the Kenyan economy and the pattern of national development since independence. Specifically, this section demonstrates how Kenya's continued dependency on external economic actors has created a development pattern that cannot generate enough employment opportunities to meet the needs of Kenyan school leavers.

Since independence in 1963, Kenya has attracted attention as one of the success stories of Africa, both politically and economicaliy. The evidence presented in this chapter questions this assumption and points to the continued vulnerability and limitations of the Kenyan economy imposed by its periphery role within the world system. Kenya's economic difficulties came to a head in the late 1970's, then spilled over into the 1980 's as real growth lost pace with the country's soaring population increase, causing a decline in per capita gross domestic product (GDP). The principal factors leading up to the economic stagnation are: a high-priced, import-intensive industrial sector; low world prices for coffee and tea; continued bottlenecks in the agricultural sector; and rapidly increasing prices for manufactured imports. Declining export receipts and high import dependence contribute to chronic balance of payments deficits and more 
hard times ahead for the Republic of Kenya. These economic problenis diminish the aspirations of school graduates in obtaining attractive modern sector jobs.

\section{PRIORITIES IN DEVELOPMENT POLICY}

Kenya has defined development in terms of the continued growth . and elaboration of the political and economic institutions established in the country during the colonial period. With respect to economic policy, the government has concentrated its attention on the achievement of rapid economic growth rates which it considers necessary to raise the standard of living in the country. The government's document outlining the official development ideology is titled, African Socialism and Its Application to Flanning in Kenya (Sessional Paper No. 10, 1965). The document's emphasis on fast economic growth is based on the assumption that social justice can be achieved only by sharing wealth, not poverty. The document points out that

The most important \{policy\} is to provide a firm basis for rapid economic growth. Other imiiiediate problems such as Africanization of the economy, education, unemployment, welfare services, and provincial policies must be handled in ways that will not jeopardize growth. The only permanent solution to all of these problems rests on rapid growth. If growth is given up in order to reduce unemployment, a growing population will quickly demonstrate how false that policy is; if Africanization is undertaken at the expense of growth, our reward will be a falling standard of living; if free primary education is achieved by sacrificing growth, no jobs will be available for the school leavers. Growth, then, is the first concern of planning in Kenya (emphasis added). 
The government has sought to promote rapid economic growth

by means of encouragement of both small-holder and large-scale farming, public investment and accelerated industrialization by providing incentives for private investment in modern industry, including foreign investment. The commitment to private investment, foreign investment in particular, is clearly stated in the latest Development Plan:

The government will continue to maintain the policy of a mixed economy. The target of high growth rate of the sector will require substantial resources for investment. Greater reliance will be placed on the private sector investment, which will include investment from abroad. As in the past, the government will continue to welcome foreign investment and to provide adequate measures to safeguard such investments. Foreign enterprises will be welcomed and will be assured the possibility of adequate repatriation of profits. (emphasis added.)

(KG5:332)

In short, the Kenyan development model can be characterized as "mixed;" it incorporates a diversity of organizational forms and incentives, and combines private enterprise with significant government participation and guidance. This approach, from the standpoint of the main thrust of growth, reflects the belief that broader social justice for the majority of Kenyans could only be achieved by pursuing a development strategy similar to the colonial economic structure.

The new strategy in essence advocated that all the main elements of the colonial economic planning approach remain intact except for (a) the conversion of parts of the former White Highlands from largescale farming to small-scale household plots for the most land-hungry peasants; and (b) ending the colonial restrictions of cash crop production in the former African Researves (CG2). Important though 
these changes were, the underlying philosophy concerning economic development was on maximizing growth, as measured in GNP. In order to obtain this narrow economic goal, imported capital, skills, and enterprises were to be the main sources of this developmental objective. The result of such strategy has been the concentration of political and economic power in one or two urban centers while effectively ignoring the development potential of the rural areas . where $90 \%$ of Kenya's population resides. In other words, the demand for infrastructure grows where political power to obtain it is the greatest.

THE STRUCTURE AND PERFORMANCE OF THE KENYAN ECONOMY SINCE INDEPENDENCE IN 1963

The first feature of the Kenyan economy revealed by an examination of the national accounts is the existence of subsistence semimonetary) and modern (monetary) sectors and a long-established tradition of exchange relations between them. There is a wide discrepancy between the two, each commanding unparalleled strength and influence in the economy. Most of the production in the traditional (or semimonetary) economy is agricultural, and a large part of the rural population's food is produced and consumed with only minimum intervention of a monetary economy. The relative contribution of the subsistence sector to the welfare of the population is greater than its relative monetary importance in terms of the gross national product. Table XIII details the percentage of the semimonetary sector's contribution to the GDP. 
TABLE XIII

PERCENTAGE OF CONTRIBUTION OF THE SEMIMONETARY SECTOR TO GDP, 1964-79

$\underline{1964} \quad \underline{1970} \quad \underline{1972} \quad \underline{1974} \quad \underline{1976} \quad \underline{1977}$

$\begin{array}{lllllll}\text { Agriculture } & 22.9 & 20.0 & 17.6 & 16.5 & 15.3 & 14.6\end{array}$

$\begin{array}{lrrrrrr}\text { Al1 other } & 4.1 & 3.5 & 4.3 & 4.3 & 4.2 & 4.1 \\ \text { Total nonmonetary } & 27.0 & 23.5 & 21.9 & 20.8 & 19.5 & 18.7 \\ \text { Total Monetary } & 73.0 & 76.5 & 78.1 & 79.2 & 80.5 & 81.3 \\ \text { Total Economy } & 100.0 & 100.0 & 100.0 & 100.0 & 100.0 & 100.0\end{array}$

Source: (KG6, 1975, 1978)

It is estimated that over $90 \%$ of Kenya's 16 million people live in the rural areas where they earn their livelihood. A large proportion of the rural population is engaged in subsistence farming, characterized by low earnings and often temporary employment (GRT52: 2). Because of population pressure and limited land for farming, the vast majority of the rural population frequently migrate to the cities in search of jobs or they work on a part-time basis in the cash crop growing multinational farms. According to one estimate (GRT07), approximately $60 \%$ of the rural labor force is migrant in any one season for two reasons: (a) jobs that occur in the modern sector are considered to be more permanent and rewarding than those in the traditional sector, and (b) in the modern sector, wages are much higher due to labor productivity resulting from scientific production methods. This has intensified competition for modern sector jobs, particularly among those with some years of formal education (GR132). 
Within the modern sector, agriculture is, of course, a major component of the economy, accounting for 34\% of GDP in 1979 (See Table XIV). The figure for 1964 was 23\%. This does not mean that Kenya was becoming more agricultural in the sense that more of its resources were being devoted to agriculture. On the contrary, the growth in the importance of agriculture in GDP has nothing to do with any actions by Kenyans. It is the result of a rise in the world price for Kenya's agricultural exports, notably coffee and tea. The export price of coffee rose from K.shs. 10/71 per kg in 1974 to K.shs. 43/33 in 1977. The price of tea rose from K.shs. $7 / 82$ per $\mathrm{kg}$ to K.shs. 20/44 in the same period (KG6, 1978). In 1975, the contribution of agriculture to monetary GDP was 18\%, yet two years later it was marginally under $30 \%$. No shift of resources into agriculture could have accounted for such an enormous change over so short a time. Its contribution has increased simply because world prices have increased. This description reflects once again the importance of semimonetary as well as monetary agriculture in the country's economy.

Since independence, the Kenyan economy has performed remarkably well despite the setbacks in the latter half of the 1970's. As shown in Table XV, there were substantial variations over the period under review, ranging from a record $7.8 \%$ in 1968 to a dismal all-time low of about $1 \%$ in 1975. Due to increases in the price of coffee and tea in 1976 and 1977, the economy achieved a growth rate of $7.3 \%$ in 1977. The dependence of the economy on a few cash crops and its consequent vulnerability can be seen from the low rate of growth achieved in 1979 and 1980 due to fluctuation in the world price for 
TABLE XIV

GDP BY SOURCE, AT CONSTANT PRICES
1964

\begin{tabular}{|c|c|c|c|c|c|c|c|}
\hline Sectors & 1964 & 1968 & 1973 & 1974 & 1977 & 1979 & $1973-77$ \\
\hline $\begin{array}{l}\text { Agriculture, } \\
\text { forestry, \& } \\
\text { fishing }\end{array}$ & 39.8 & 36.3 & 34.6 & 29.8 & 29.0 & 36.0 & -0.1 \\
\hline (semimonetary) & $(22.9)$ & $(21.0$ & $(18.5)$ & $(15.3)$ & $(14.6)$ & $(0.7)$ & $(-1.1)$ \\
\hline (monetary) & $(16.9)$ & $(15.3)$ & $(16.2)$ & $(14.5)$ & $(14.4)$ & $(35.3)$ & $(0.9)$ \\
\hline $\begin{array}{l}\text { Manufacturing } \\
\text { repairing }\end{array}$ & 10.4 & 10.4 & 11.6 & 13.3 & 15.6 & 13.2 & 10.8 \\
\hline $\begin{array}{l}\text { Building \& } \\
\text { construction }\end{array}$ & 3.8 & 4.3 & 4.2 & 6.5 & 5.3 & 3.9 & 11.0 \\
\hline $\begin{array}{l}\text { Electricity \& } \\
\text { water }\end{array}$ & 2.1 & 1.9 & 2.1 & 1.8 & 2.4 & 1.3 & 8.3 \\
\hline $\begin{array}{l}\text { General govern- } \\
\text { ment Services }\end{array}$ & 12.8 & 14.6 & 16.8 & 15.1 & 17.8 & 14.5 & 5.5 \\
\hline Other Services & 31.1 & 32.5 & 30.7 & 33.5 & 29.9 & 13.5 & 3.3 \\
\hline $\begin{array}{l}\text { Total } \\
\text { Economy }\end{array}$ & 100.0 & 100.0 & 100.0 & 100.0 & 100.0 & 100.0 & 4.0 \\
\hline
\end{tabular}

coffee and tea as well as the increase in the price of imported oil. The growth rate is likely not to exceed $3 \%$ before 1984 , still well below the targeted rate of $5.4 \%$ mentioned in the latest Development Plan (KG5) (GR152). Continued economic problems mean limited expansion of employment opportunties and thus, prolonged unemployment for the school Teavers.

For a proper understanding of the performance of the economy, two time frames are established. The first phase covers the period 1964-73 
TABLE XV

ANNUAL AVERAGE RATE OF GROWTH OF GDP

(AT 1972 CONSTANT PRICES)

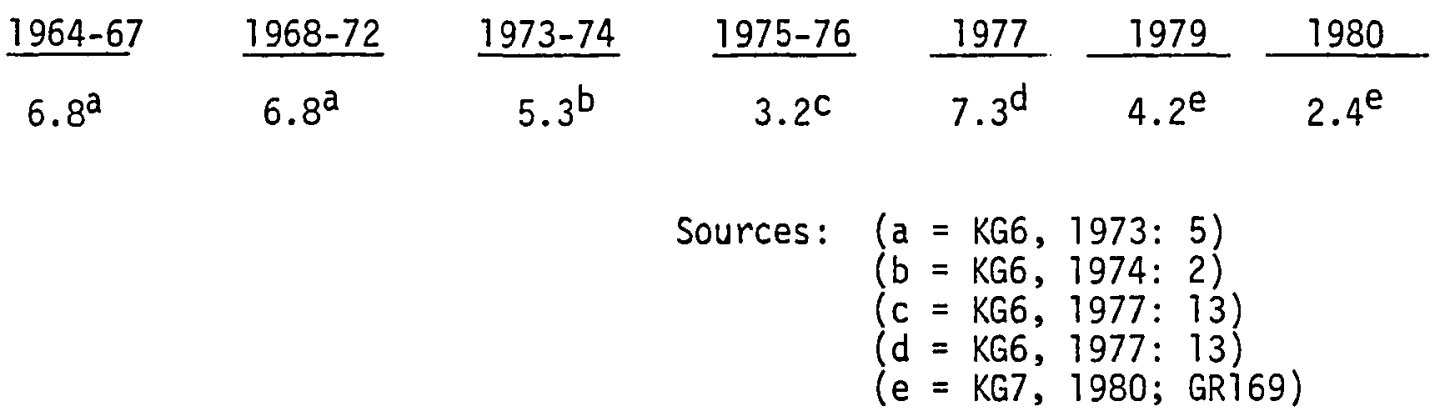

when the economy grew steadily at an annual rate of $6.6 \%$; and the second phase is 1973-80, when, as a result of the impact of a series of international crises, widespread drought which affected agriculture, and the balance-of-payment difficulties, growth slowed down substantially. A boost came in 1976 and 1977 from an unprecedented boom in the world price for coffee and tea. The boom was followed by another severe balance-of-payments problem.

The impetus for growth in 1964-73 came mainly from the monetary economy comprising modern sector activities--manufacturing, agriculture, and services--which grew at an annual average rate of $7.5 \%$ as compared with about $3.7 \%$ for the semimonetary economy, made up mostly of traditional subsistence and smal1-holder cash crop agriculture (KG6, 1971, 1974). Agricultural growth was stimulated by redistribution of large estates to small-holder, rapid diffusion of hybrid maize, and small-holder output growth. Manufacturing was stimulated by the expansion of domestic demand due to rising agricultural incomes. Investment for domestic production was encouraged by a high 
level of protection, a liberal attitude towards foreign investment, and active government promotion of and some participation in manufacturing (KG18). Despite a rapid growth of population between 1964 and 1973 averaging $3.6 \%$ annual7y, real income per head increased an average of nearly 3\% per annum over this period (KG6 \& KG7, 1964-73). In monetary terms, GDP per head at current prices increased progressively from about $K t 35$ in 1964 to $K t 58$ in 1973 (KG6, 1965, 1974). One item which is of particular interest to this study is the fast growth of general government services. Its contribution to total GDP increased from $12.8 \%$ to nearly 17\% between 1964 and 1973 (see Table XIV), due mainly to the rapid expansion of education in the decades after independence. At present, an average of approximately $30 \%$ of the total government expenditure is spent on education. Kenya's growth performance since 1974 has been especially vutnerable to swings in its international terms of trade. Whereas an average annual growth rate of approximately $7 \%$ was achieved between 1970-73, it fell sharply to $3.5 \%$ in real terms in 1974, and still further to about $1 \%$ in 1975 (KG6, 1977). This was attributed to the disappointing growth of agriculture (see Table XIV), traditionally Kenya's most important sector. The dramatic increase in petroleum and other import prices raised input costs (i.e., fertilizers and imported equipment) in monetary agriculture, and the widespread drought throughout Kenya in 1973 and 1974 adversely affected output in both traditional and modern sector agriculture, but particularly the former. The economy rebounded in 1976-77 due to the "coffee boom" following frost damage in Brazil, and decelerated after 1978 when 
coffee prices began to approach a more normal level.

Manufacturing growth, on the other hand, was less affected than growth in the other sectors of the monetary economy by the events of 1973 and 1974. The average growth rate of the manufacturing sector was $16.9 \%$ between $1970-79$, as opposed to $11.3 \%$ in $1964-70$ (KG6, 1980: 29). Manufacturing share in the GDP rose from $12.5 \%$ in 1964 to $15.6 \%$ in 1977. In 1979, the manufacturing share of GDP was $13.2 \%$, while the share of agriculture in GDP was $36 \%$. This indicates the continuing preponderance of agriculture as the major productive sector of the economy, despite the effort that was made to develop the manufacturing industry at a rapid rate.

The dramatic growth of industry in Kenya has been largely based on simple import-substitution industries developed by multinational companies (GR76; GR102). Manufacturing production also catered to the export markets in neighboring countries, particularly in the protected East African Community (EAC). The scope of further industrialization along these lines is limited; the easy import substitution possibilities have been exhausted, and the EAC preference for Kenyan goods ended with the collapse of the community in 1977. The past pattern of industrialization has left Kenya's manufacturing sector increasingly dependent on imported raw materials and component and spare parts, and thus vulnerable in case of a shortage of foreign exchange.

According to the Development P1an, 1979-83 (KG5: 327), about $50 \%$ of Kenya's import bill is accounted for by capital and imported intermediate goods. Machinery and capital equipment account for 
approximately $20 \%$ of a 11 imports, and intermediate industrial supplies account for $30 \%$. As the manufacturing sector grows rapidly, its demand for imported inputs is.-bound to increase at an equally fast rate. The result has been a foreign exchange bottleneck. It has become necessary to reorient industry toward increased use of domestic inputs and increased production. However, export performance has not been satisfactory in that it has grown consistently at a slower pace than GDP and has not shown sufficient diversification.

The most disturbing aspect of recent performance, from the point of view of future growth prospects, has been the chronic underlying tendency toward a trade and balance-of-payment deficit, which reflects the capital-intensiveness of the import-reproduction process (with huge increases in the import bill) and the fact that the end of the easy stage of that process was virtually exhausted by 1972 . The 1975-77 coffee boom disguised this tendency for a time. But during 1978-80, Kenya again experienced strong external shocks as a result of the latest round of petroleum price increases and declining coffee prices. The balance-of-payments and income effects of these increases were compounded by poor weather affecting coffee and maize production. Once a self-sufficient nation, Kenya can no more feed its own people adequately. As a result, GDP growth slowed to $4.2 \%$ in 1979 and to an estimated $2.4 \%$ in 1980 (GRT52, GR153). The trade deficit rose very sharply in 1978, and foreign exchange reserves rapidiy diminished. The increase in petroleum prices, combined with additional food imports, resulted in a $25 \%$ rise in the value of imports in 1980 (KG6, 1981). While exports rose by $16 \%$, this was not sufficient to prevent 
an increase in the current account deficit to almost US $\$ 900$ million, and, despite increased external borrowing, a decline of US\$195 million in foreign exchange reserves (GR169, PI16,17).

Despite an impressive rate of growth in GNP, unemployment and gross inequalities in Kenya continue. In many cases, these inequalities may have been accentuated by the policies of the government and the country's position as a periphery of Western capitalism. A World Bank staff member estimated that for 1969, the poorest $40 \%$ of Kenya's population received only $10 \%$ of the total income, while the richest $10 \%$ received $56 \%$; the top $5 \%$ obtained $44 \%$ of the income, and the top $1 \%$ received $8 \%$ (GR 111 ). When compared with other countries, the interpersonal distribution of income in Kenya is among the most unequal in the world. A cross-national study conducted by Chenery et al (GR33) ranks Kenya as the seventh most unequal of twenty-six countries, with only Rhodesia (now Zimbabwe) under European racist rule being more unequal in Africa. And there is not any significant evidence of an improvement in this situation during the 1970's and 1980's. These sharp inequalities inevitably create strong ambitions among the populace to migrate to the cities, to strive for higher education, to search for jobs. As long as extreme imbalances persist, so will unemployment and poverty.

Foreign Investment and Governmental Policy

The Kenyan government has taken a positive stance toward foreign investment in the country, particularly when there is Kenyan equity : participation. And there are, at present, no legal limitations on the 
percentage of foreign ownership. This policy is part of an overall effort to industrialize Kenya and to reduce its reliance on agriculture to provide employment for its nationals. In the pages that follow, by evaluating past and present performance of foreign investors and the overall impact they have had on Kenya, one is led to question the extent and type of employment efforts undertaken to date in the country.

Since independence, emphasis has repeatedly been placed in the Development Plans upon achieving an ambitiously rapid rate of growth of industrial output, while at the same time, a domestic resource gap has been identified as a major constraint to the achievement of the target growth rate. And there has been an explicit decision by the government to rely heavily upon foreign sources of finance (both investment and aid) as an integral feature of its development strategy. The Sessional Paper on African Socialism stated that

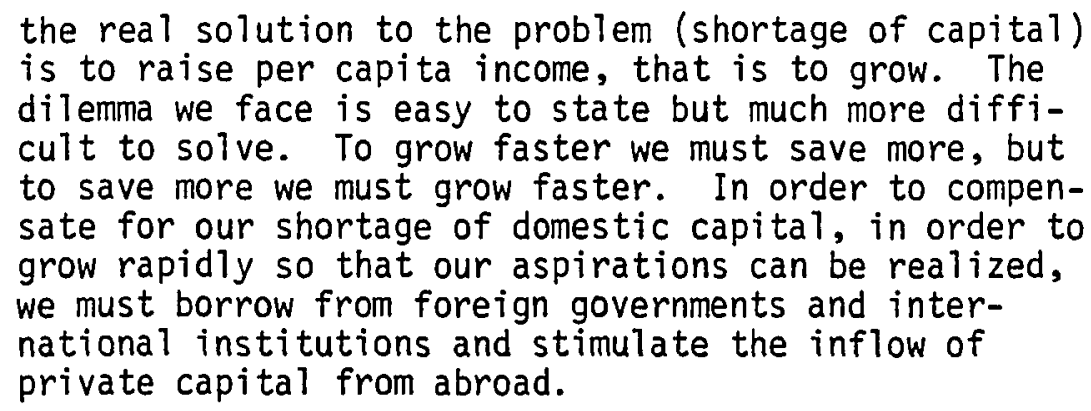

(KGT: 19)

One important aspect of the industrialization policy has been the open door policy towards foreign investment. The Foreign Investment Protection Act of 1964 signifies the importance the government 
attaches to foreign investment in national development. The Act provided for the issuing of a guarantee certificate to existing and new foreign investors, provided the Minister of Finance considered the object of their investment (or reinvestment projects) to be in the best interests of Kenya (KG18: 3-4). The Act further stipulated that the holder of a Certificate of Approved Enterprise could transfer out of Kenya, in the approved foreign currency and at the prevailing rage of exchange:

- the profits, after taxation, of his investment of foreign assets;

- the approved portion of the net proceeds of sales of all or any part of the approved enterprise, either in liquidation or as a going concern;

- the principal and interest of any loan specified in the certificate (p 26).

The Act further reaffirmed that no approved enterprise or any property should be compulsory in the taking of possession and acquisition and in the payment of full and prompt compensation contained in Article 73 of the Constitution of Kenya.

Foreign companies benefit from a number of incentives accorded them by the government. The most important of these are the freedom of repatriation of profits, liberal depreciation allowances on their investments, and product market protection from other competitors. Generally, after tax profits, excluding profits of a capital nature, may be remitted only on equity capital brought into Kenya. After tax, there is a withholding tax on dividends remittances. Interest 
on approved loans, which can be acknowledged in foreign currency, may be repatriated subject to a deduction of withholding tax. Repatriation of royalties and service fees is subject to the approval of an agreement by the Central Bank, and withholding tax is deductible.

Corporate Taxes. The corporate tax rate for industrial enterprise is $45 \%$ of the net profits, excluding dividends received from resident companies. The tax on the income of branches of foreign firms is $52.5 \%$ (GR152: 20). Profits from life insurance business and the mining of certain specified minerals are taxed at a lower rate. New mining companies are afforded partial tax relief by paying onty $28 \%$ for five years after the company initially makes a profit (GR152: 20).

Companies that deliberately accumulate profits so that shareholders can avoid taxation or distribute them in a nontaxable form are subject to further tax under the anti-avoidance provisions of the Income Tax Act. The withholding tax rates from January 1, 1982 are as follows: a $20 \%$ tax on dividends and a $20 \%$ tax on interest have been introduced to be paid by residents and nonresidents. A withholding tax of $30 \%$ has been imposed on all payments of management fees and royalties to nonresidents (GR 154 : 415, Section 152). Where double taxation agreements exist between Kenya and the recipient country of residence, these rates are reduced.

The various taxes imposed on foreign investors, however are never fully realized. According to the ILO Report (GR69: 437), foreign companies remit their net profits to their parent companies without paying tax, and in various cases, they have been shown to 
underdeclare their true profitability. By remitting accrued profits through other channels (such as royalties, transfer pricing on intermediates, interest payments on interaffiliate debts, overinvoicing, etc), they are achieving considerable tax avoidance in Kenya (GR69: 453-456; GRT02). For example, Exchange Control authorities in Kenya estimated that overpricing of intermediate goods is 20 to $30 \%$ more than they would fetch on the open market (GR69: 454). The combined effect of this is to reduce the potential inflow of foreign exchange and revenues required for economic development. As indicated in Table XVI below, the dividend outflow for 1970 was almost equivalent to

TABLE XVI

INFLOW AND OUTFLOW OF CAPITAL

(Kt ' 000 )

\begin{tabular}{|c|c|c|c|c|}
\hline Year & $\begin{array}{l}\text { Profits (After Tax } \\
\& \text { Depreciation) } \\
\end{array}$ & $\begin{array}{l}\text { Retention } \\
\text { Ratio } \\
\end{array}$ & $\begin{array}{l}\text { Dividend } \\
\text { Outflow } \\
\end{array}$ & $\begin{array}{l}\text { Inflow of New } \\
\text { Capital } \\
\end{array}$ \\
\hline 1963 & 9,843 & 36 & 6,329 & 6,286 \\
\hline 1964 & 8,665 & 41 & 5,119 & 7,254 \\
\hline 1965 & 8,731 & 35 & 5,713 & 5,782 \\
\hline 1966 & 8,750 & 32 & 5,950 & 700 \\
\hline 1967 & 9,079 & 53 & 4,267 & 5,934 \\
\hline 1968 & 11,791 & 65 & 4,127 & 4,428 \\
\hline 1969 & 12,515 & 54 & 5,757 & 6,147 \\
\hline 1970 & 17,428 & 54 & 8,017 & 9,447 \\
\hline
\end{tabular}

* These are declared outflows. Real outflow can be very different owing to the use of transfer pricing.

Source: (GR116, GR69: 136, Table 37) 
the inflow of new capital into the country. In order to finance the outflow of dividends, government policies have to be continually shaped so as to attract a high rate of foreign investment. Such policies are manifestations of the dependence and underdevelopment of Kenya and emphasize its powerlessness to shape the course of national development independentiy. Under such conditions, the ability of the Kenyan government to formulate and implement policies directed toward the problem of graduate unemployment is severely circumscribed.

Subsidies and Other Incentives. In addition to the repatriation of profits, Kenyan tax law specifies various other permissible investment deductions to attract foreign investors. The government advertises that "an industrialist can write off $120 \%$ of his investment against taxable income over a period of a few years" (KG17: 3). Since 1975, however, the initial investment allowance has been restricted to $20 \%$ of investments in the rural areas or small towns (GR69: 438; KG19). This allowance, which at current company tax rates represents a subsidy of $9 \%$ of new investments in fixed assets, was designed to encourage a wider geographical distribution of investments.

Annual deductions for certain classes of capital expenditures incurred for business purposes are allowed as follows:

- Industrial buildings, such as factories: $4 \%$, and "approved" hotels: $6 \%$ annually on the expenditure incurred.

- Plant and machinery: heavy self-propelling vehicles such as tractors: $38 \%$ on the declared value; other self-propelling vehicles such as cars: $25 \%$; all other machinery, including 
ships: $12.5 \%$.

- Mining: $40 \%$ of expenditure in the first year and $10 \%$ in each of the following years.

- Farm works: 20\% of expenditure in the first and each of the four following years.

An investment deduction is also given on the capital cost of construction: $40 \%$ on ships, $20 \%$ on new factory buildings and new machinery installed in them, and a 20\% deduction on new hotels (GRT52: 17).

Even so, recent studies by Norcliff (GRI19) and Richardson (GRT33) indicate that investment deductions do little to stimulate investment and industrial dispersion. Norcliff argues that since most industries believe that the greatest efficiency is to be achieved in Nairobi and Mombasa, there is very little pressure for localization outside the two big cities. According to estimates made by the ILO (GR69: 438), investment deductions had a revenue cost of about $L 330,000$ a year in 1966 and 1967 . This is equivalent to more than $1 \%$ of government revenue from direct taxation in those years.

The availability of loans and equity participation by the government in manufacturing investments is another form of financial incentive. The extent of access to local capital for foreign enterprise has varied from time to time, and bank borrowing had been restricted to an amount equal to between 20 and $60 \%$ of the foreign

The consequent unavailability of such revenues directly impacts the performance of the economy and hence the expansion of employment opportunities to Kenyans. 
equity (GR69: 452). However, local funds are available from other banks, including statutory bodies. The Industrial and Commercial Development Corporation (ICDC), the Development Finance Company of Kenya (DFCK), and the Industrial Development Bank (IDB) lend money to foreign multinationals who participate in joint venture activities with the government. Using data collected by Herman (GR60: 452) and conbining it with the UNCTAD (GRI16) data, the ILO Mission estimated that about $30 \%$ of all local private and public capital invested in manufacturing during 1964-70 went into foreign-owned companies. Furthermore, joint venture activities provide foreign corporations new avenues of access to the national policymaking process. This point is supported by the findings generated from the case study of the Industrial and Commercial Development Corporation presented at the end of this chapter. The findings of the case study suggest that Kenya's attempt to maintain national control of the economy through public investment has been unsuccessfut.

Probably the most important incentive to foreign investment is, in fact, the protection which is accorded to many activities; and it has been suggested that "foreign firms are lodged securely where protection is highest" (GR68). Protection is given by import duties, by licensing and quantitative restrictions, and by remissions and drawbacks of duty paid by manufacturers on imports used in production. Duties on most imported items range from 13 to $75 \%$ (GR152:6). In 1981, the Kenyan government unveiled a new import policy linked to a revised tariff schedule in an effort to shift emphasis from import substitution to promotion of industrial exports and the 
elimination of quantitative restrictions and import licensing. Henceforth, all imported goods will be categorized into three import schedules on the basis of their importance to the Kenyan economy. The three schedules are as follows: Schedule I (most essential, i.e., raw materials, capital goods, spare parts, etc), Schedule IIA (priority goods used in industry or agriculture and petroleum products), and Schedule IIB (nonessential goods, for which domestic equivalents or substitutes exist). Schedule IIB items will receive the foreign exchange remaining after the demand for the importation of more essential goods is satisfied.

Like the tax laws, the new import policy is not strictly enforced. Individual investors are able to negotiate special protection for their investments. As the manager of one American subsidiary put it:

We used to put $100 \%$ deposit before importing capital goods into the country. Not anymore, thanks to the Kenyan representative on our Board of Directors. When our partners cannot make a breakthrough, our Managing Director goes directly to the President of the Republic.

In addition, the leve 1 of restrictions vary with the country's balanceof-payments situation. At present, due to a deficit position and because of increasing fuel costs, controls are rigidly applied.

A survey of 50 foreign subsidiaries that have significant domestic-oriented manufacturing investments indicate that $48 \%$ of them have sought protection and another 38\% were seeking protection in 1973 (GR99). Out of the 19 subsidiaries involved in entry negotiations 
in $1973,53 \%$ were seeking import protection, while another $32 \%$ were seeking the right to import machinery and/or inputs duty free. Most of these subsidiaries achieved their objectives successfully. The profits obtained through protection from sales on the domestic market, together with the provision for the expatriation of funds, make it possible--indeed provide an incentive for foreign firms "to expatriate foreign exchange they have neither earned nor saved" (GR169: 310).

TABLE XVII

\section{SUBSIDIARY REQUEST FOR IMPORT PROTECTION}

(1)

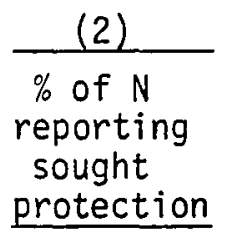

$\mathrm{N}$ protection

50



successfully

$38 \%$

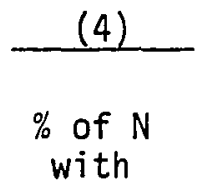

protection

$38 \%$
(5) (6)

(3)

as $\%$ (3)

$76 \%$

Major Issues Raised in Entry Negotiations by Subsidiaries $(N=19)$ :

$\%$ of 19 subs. $\quad \%$ of achievement involved of objectives

- Seek import protection via tariff

- Seek right to import machinery/inputs duty free

- Seek government finance in project

- Seek guarantee against domestic competition

- Seek long-term status quo clause

- Seek guarantee or work permits

- Seek approval for generous free agreements
$53 \% \quad 90 \%$

$32 \% \quad 100 \%$

$16 \% \quad 67 \%$

$17 \% \quad 100 \%$

$11 \% \quad 100 \%$

$11 \% \quad 100 \%$

$17 \% \quad 100 \%$ 
A study conducted by M Phelps and B Wasow (GRT28) concluded that consumer goods industries generally received a significantly higher level of effective protection (69\%) than those producing intermediate goods (20\%). Comparing the ranking of industries by the level of effective protection they were receiving and by their profitability at world prices, Phelps concludes that there is a significant negative correlation between the two. In other words, industries receiving the highest levels of protection tended also to be the least profitable at world market prices (GR128: 25). A high degree of effective protection may either enhance the profitability of the protected activity at the expense of local consumers, or, alternatively, may either allow a high degree of inefficiency to exist or may make nonviable industries artificially profitable. The primary cost of resource misallocation suggested here must relate to the increased cost of living and the loss of consumer surplus which result from the ability of producers in Kenya to charge high prices behind the tariff barriers. The protected industries are not infant industries; rather, they are subsidiaries of large multinationals whose employment contribution is very limited. The result is a structure of effective protection with a wide dispersion of rates and little connection between the protection rate and the need for protection. This situation does not best serve Kenya's developmental objectives: rapid economic growth, social equality, and expanded employment opportunities.

The protective system also allows free entry of intermediate products. This free entry provides a specific encouragement for manufacturers to use imported inputs and directly discourages the domestic 
production of intermediate goods, which reinforces the tendency of manufacturing investment to concentrate on final-stage processing (GR99). It also encourages the use of productive methods which use imported capital rather than local labor. According to ILO estimates, duty drawbacks on imported intermediate goods and capital equipment in 1969 were equivalent to a revenue loss of $K t 1.3 \mathrm{million}$ (GR69: 438 ). On the whole, protection and permission to export profits together confer great benefit on the foreign investor, while depriving Kenya of the needed foreign exchange inflow required for expanding the economy and employment opportunities.

Scale of Foreign Enterprise in Kenya. Oniy limited evidence exists on the financial structure of foreign enterprise in Kenya. Many private companies in the estate sector are owned by foreigners, and a number of subsidiaries of major enterprises are also set up as private companies. The larger subsidiaries, particularly those that seek government equity participation, are public companies.

In agriculture, most of the large settler estates have now been taken over by indigenous Kenyans, and much of the prime land has been subdivided into small holdings. Foreign investment remains high in tea and coffee estates. According to ILO estimates, about $40 \%$ of the coffee and $70 \%$ of the tea produced in Kenya come from estates (GR69: 431). Only pineapple growing and processing is still dominated by Del Monte, registered under its subsidiary, Kenya Canners Ltd.

In the private service sector, foreign investment has lost its dominance, with the possible exception of tourism--the second largest foreign exchange earner. Similarly, foreign trading companies which 
failed to move into manufacturing have also been taken over by local capital, although takeover here does not imply independence by indigenous firms. On the contrary, indigenous firms are dependent on foreign investment for both technology and financial capital (GR69; GR77; GRT02).

The greatest part of foreign direct investment in Kenya has been in import-substituting industries, particularly textiles, footwear, assembly industries, paper and paper products. Studies undertaken by Kaplinsky (GR77) on the ownership of all large scale manufacturing and all tourist firms in 1966 (GR114) and 1976, summarized in Table XVIII. show the share of this foreign investment and how it changed in the period between 1966 and 1976 . The 285 firms operating in 1966 and 421 firms operating in 1976 are subdivided into two different categories for analytical purposes: by sector and by size of issued capital. As indicated in the table, foreign subsidiaries are predominant in footware, leather, rubber, industrial chemicals, paint, soap, cement, and metal products. Despite a decline in recent years, food and beverages still remain preeminent.

While the share of foreign investment in total equity varies over time and by sector and size of the group, the most striking observation is that the share of total equity owned by foreign capital declined from $59.3 \%$ in 1966 to $42 \%$ in 1976 . However, this cannot be taken as evidence that foreign enterprise is losing its dominance in the Kenyan economy. The decline reflects the tendency of large foreign firms to sell off a minority of their share holdings to individual Kenyans or to state corporations. While the proportion of foreign equity in the 
TABLE XVIII

SUMMARY OF FOREIGN OWNERSHIP IN LARGE SCALE MANUFACTURING AND TOURIST FIRMS, 1966-76

\begin{tabular}{|c|c|c|c|c|c|c|c|c|}
\hline \multirow[b]{2}{*}{$\begin{array}{l}\text { Type } \\
\text { of } \\
\text { firm }\end{array}$} & \multicolumn{3}{|c|}{1966} & \multicolumn{3}{|c|}{1976} & \multicolumn{2}{|c|}{$1966-1976$} \\
\hline & $\begin{array}{c}\text { Total } \\
\text { issued } \\
\text { capital } \\
\text { KL }\end{array}$ & $\begin{array}{c}\text { Total } \\
\text { foreion } \\
\text { owned } \\
\text { issued } \\
\text { capital } \\
\text { KL } \\
\end{array}$ & $\begin{array}{l}\text { Nof of } \\
\text { issued } \\
\text { capital } \\
\text { foreign } \\
\text { owned } \\
\text { KL }\end{array}$ & $\begin{array}{c}\text { Total } \\
\text { issued } \\
\text { capital } \\
\mathrm{KL}\end{array}$ & $\begin{array}{c}\text { Total } \\
\text { foreign } \\
\text { owned } \\
\text { issued } \\
\text { capital } \\
\quad \mathrm{kL}\end{array}$ & $\begin{array}{l}\text { nof of } \\
\text { issued } \\
\text { capital } \\
\text { foreign } \\
\text { owned }\end{array}$ & $\begin{array}{c}\text { Growth of } \\
\text { total } \\
\text { issued } \\
\text { capital } \\
\quad \% \\
\end{array}$ & $\begin{array}{c}\text { Growth of } \\
\text { foreign } \\
\text { issued } \\
\text { capital } \\
\%\end{array}$ \\
\hline \multicolumn{9}{|l|}{ (a) by industry } \\
\hline Food, beverages & $14,876,072$ & $7,250,526$ & 48.7 & $45,863,454$ & $13,253,442$ & 28.9 & 308 & 183 \\
\hline Textiles, leather & $2,150,727$ & $1,223,597$ & 59.6 & $14,849,560$ & $8,393,968$ & 56.5 & 690 & 686 \\
\hline Wood, furniture & 435,660 & 5,000 & 1.2 & $1,264,697$ & 189,546 & 15 & 290 & 3,791 \\
\hline Paper, printing & 528,486 & 5,291 & 1 & $8.104,734$ & $3,279,144$ & 40.5 & 1,534 & 61,976 \\
\hline Chemicals, rubber & $8,628,955$ & $7,698,132$ & 89.2 & $19,121,916$ & $13,607,520$ & 71.2 & 222 & 177 \\
\hline Pottery, glass & $2,241,450$ & $1,126,352$ & 50.3 & $2,337,000$ & $1,036,980$ & 44.4 & 104 & 92 \\
\hline Basic metals & 300,004 & 100,003 & 33.3 & $2,100,000$ & 571,725 & 27.2 & 700 & 572 \\
\hline $\begin{array}{l}\text { Fabricated metal } \\
\text { products }\end{array}$ & $1,814,776$ & $1,154.340$ & 63.6 & $8.713,301$ & $4,438,560$ & 50.9 & 480 & 385 \\
\hline Other manufacturing & 103,770 & 73,614 & 70.9 & 443,008 & 143,459 & 32.4 & 427 & 195 \\
\hline Total manufacturing & $31,079,540$ & $18,636,831$ & 60 & $44,914,116$ & $19,627,468$ & 43.7 & 331 & 241 \\
\hline Large tourist & 785,190 & 13,181 & 1.7 & $7,709,327$ & $2,017,287$ & 26.2 & 982 & 15,205 \\
\hline Small tourist & 51,015 & NA & NA & $1,366,281$ & 2 & $\mathbf{0}$ & 2,678 & NA \\
\hline
\end{tabular}

(b) by size of

issued capital

$\frac{(K L)}{1-}$

$\begin{array}{rr}1- & 99 \\ 100- & 999\end{array}$

$1,000-9,999$

$10,000-49,999$

30,000-199,999

200,000-999, 999

Over $1,000,000$

$\begin{array}{rr}66 & 6 \\ 3,762 & 987 \\ 240,460 & 30,325 \\ 1,690,013 & 481,869 \\ 5,000,120 & 2,629,740 \\ 10,330,875 & 5,574,177 \\ 14,173,740 & 9,932,89\end{array}$

$\begin{array}{rrrr}9.1 & 115 & 6 & 5.2 \\ 26.2 & 4,760 & 539 & 11.3 \\ 12.6 & 307,650 & 27,980 & 9.1 \\ 28.5 & 2,258,508 & 387,032 & 17.1 \\ 52.6 & 12,331,231 & 4,246,753 & 34.4 \\ 5.4 & 33,407,599 & 15,409,875 & 46.1 \\ 70.1 & 63,562,890 & 26,859,127 & 42.3 \\ 59.3 & 111,872,750 & 46,931,312 & 42\end{array}$

Totals

$31,439,046 \quad 18,650,000$

174
127
128
134
247
323
449
355

100
55
92
80
162
277
270

251.6

Source: (GR77: 9) compiled from Kenya Central 
wholly owned category (95\%-100\%) fell from $76.3 \%$ to $45.4 \%$ between 1966 and 1976, the proportion in the majority-owned category (50-95\%) rose correspondingly from $16.2 \%$ to $48 \%$ (GR77: 15). Despite the growth of small, indigenously owned firms, there is little evidence to suggest that the dominant position pf foreign investment eroded in the first 13 years after independence. Furthermore, the increased involvement by parastatals in joint venture has not been accompanied by an impressive rate of return. While the rate of return for other companies averaged between $12 \%$ and $25 \%$ in the mid-1970's, the corresponding figure for state investments was only 5\% (GR77: 11; GR102: 25). In short, the influence of foreign capital has increased over the years (see Table $X I X)$, and there is no suggestion that such influence will decline in the future. What the evidence suggests is that as long as the economy is controlled from the outside, the capacity of the government to design and implement policies directed toward the problem of urban unemployment is severely limited.

Choice of Technology. Concern with the "employment problem" inevitably raises the question of the nature of technology employed in the Kenyan manufacturing sector. Foreign-owned subsidiaries typically produce inappropriate products (those demanded by a small, rich minority of the local population), stimulate inappropriate consumption patterns through advertising and monopolistic market power, and operate with inappropriate (capital-intensive) technologies of production. This is perhaps the major area of criticism of multinational corporations (GR14; GR76; GR99).

Results from available studies on the capital-intensity of Kenyan 
TABLE XIX

DISTRIBUTION OF PARASTATAL INVOLVEMENT BY OWNERSHIP

\begin{tabular}{|c|c|c|c|}
\hline & $\begin{array}{r}1966 \\
(8000) \\
\end{array}$ & $\%$ & $\begin{array}{r}1976 \\
(8000) \\
\end{array}$ \\
\hline tal parastatal invol & 3,688 & 100 & 83,722 \\
\hline
\end{tabular}

Parastatal involvement in companies with:

a) majority shareholding by foreign company

$1,797 \quad 48.7 \quad 9,006 \quad 10.6$

b) minority shareholding by foreign company

$\begin{array}{llll}1,163 & 31.5 & 50,105 & 59.8\end{array}$

c) majority shareholding by locally resident Europeans

$\begin{array}{llll}516 & 14.0 & 2,176 & 2.6\end{array}$

d) minority shareholding by locally resident Europeans

173

$4.7 \quad 3,651$

4.4

e) majority shareholding by locally resident Asians

143

$3.9 \quad 6,331$

7.6

f) minority shareholding locally resident Asians

$\begin{array}{rrrr}- & - & 2,290 & 2.7 \\ 5 & 0.1 & 2,168 & 2.6 \\ 4 & 0.1 & 15,263 & 18.2\end{array}$

g) majority shareholding by Kenyan Africans

h) minority shareholding by Kenyan Africans

Source: $(77: 12)$

manufacturing are mixed. Certain analysts have concluded that foreignowned subsidiaries tend generally to be more capital-intensive than their locally-owned counterparts (GR69; GR125). Others challenge this view and conclude that foreign-owned subsidiaries make stronger use of labor-intensive techniques. The suggested explanation for this latter view is that the subsidiaries employ more skilled supervisory staff and, 
because of better management, use staff members more effectively than local firms do. Better supervision permits the use of productive techniques which employ unskilled labor relatively efficiently (GR69; GRT25; GR126). Simply put, this means that firms deficient in technical supervision must rely heavily upon machines, so that their technology is more capital-intensive.

Langdon, making a particularly pointed observation on the shoe and soap industries, concludes that foreign-owned subsidiaries are more capital intensive than their locally-owned counterparts, largely because of the sector of their operation (GR99: 66-96). Drawing on Stewart (GRT45) and Lancaster's (GR97) work, he distinguishes between high income and low income products and notes that high income products frequently necessitate the use of a capital-intensive technique. A head office monopoly of policies regarding machinery purchase and product quality control forces local managers of subsidiaries to adopt inappropriate capital-intensive techniques. Thus, to the extent that foreign-owned subsidiaries rely on their parents' portfolio of high income goods (which Langdon shows to be overwhelmingly the case), they are forced to utilize capital-intensive techniques which minimize the expansion of employment in Kenya.

A highly significant part of this tendency to produce high income products with capital-intensive techniques is the systematic attempt which foreign-owned subsidiaries make to influence consumer taste preference towards the choice of such products. Langdon (GR102: 60) offers some limited evidence to support this argument. More recently, a comprehensive listing of all advertising expenditures in various 
media has become available.* Analysis of this data shows that of the 100 most advertised products in 1976, only 14 were produced by majority locally-owned firms, some of which were manufactured under license from foreign firms. Moreover, of the top 10 most advertised products, all were produced by foreign-own subsidiaries; and six were produced by the Unilever subsidiary. Of these six, three were differentiated forms of the same product (i.e., cooking fat). Of the total of 27 subsidiaries interviewed by Langdon, $11.1 \%$ allocated over $10 \%$ of sales to advertising; $22 \%$ allocated $5-10 \%$ of sales; and $18 \%$ allocated $2.5 \%$ of sales to advertising in 1973 (GR103:6). Details on advertising confirm the degree of high income product promotion in the country.

The tendency of foreign-owned subsidiaries to produce high income products using labor saving devices is having an important impact on locally-owned firms. From his study of the soap industry, Langdon concludes that the locally-owned firms were being forced into replicating the products and production techniques of the foreignowned subsidiaries. In another sector, breakfast foods, the emerging market for high-income products (actively reinforced by advertising) has led two local firms to produce under license products which entail the choice of imported capital-intensive techniques. Thus, while an equivalent expenditure on machinery to manufacture traditional breakfast foods would provide 600 jobs producing a domestic value added of $\$ 3.6$ million, a production of high income breakfast cereals created only 15 jobs with a domestic value added of only $\$ 325,000$ (GR78). It is reasonable to conclude that the employment and sectoral linkage of multinational investment is limited because of the capital intensity Kenya Media Advertising Review, 1976 (Nairobi, Corcoran \& Tyrell, 1978). 
of the industry.

Manufacturing Output and Import Dependence. The rapid growth of industry based on multinational corporations has imposed many demands on Kenya's economy which it is incapable of meeting. The continued reliance on foreign technology and inputs has contributed to chronic trade and balance-of-payments deficits. Eight out of ten firms interviewed for this study admitted that they import $100 \%$ of their capital goods (machinery) and approximately $75 \%$ of their raw materials or imported inputs (PI18-25). In the case of the rubber and automobile industries, $100 \%$ of the raw materials and other inputs were imported $(P I 18,19)$. These findings are consistent with the findings of other studies.

In his comprehensive study of multinationals in Kenya, Langdon (GR101: 108) found that $98 \%$ of Kenyan firms imported more than $70 \%$ of their machinery. Of those subsidiaries, $79 \%$ imported more than $95 \%$ of their machinery. Another $69 \%$ imported more than $70 \%$ of their raw materials. In the case of soap manufacturing, the subsidiaries imported 75-90\% of their material inputs, while the less mechanized local Asian firms imported $40-50 \%$ of their inputs (GRI01: 69). In shoes, the subsidiary imported $50-60 \%$ of its inputs, while the local small-scale shoe manufacturers purchased virtually all their inputs locally (GR101: 80). Moreover, for subsidiaries as a whole, there was very little evidence of potential improvements in local linkage effects in the future. The vast majority of subsidiaries interviewed (al1 but 6 out of 48 in domestic market manufacturing) saw no prospects for future subcontracting to local manufacturers. Lack of linkage means limited expansion 
of the Kenyan economy and hence limited employment opportunities for the school leavers. Table $X X$ demonstrates the import dependence of Kenyan manufacturing.

TABLE XX SUMMARY OF IMPORT DEPENDENCE OF KENYAN MANUFACTURING $1966-74 \quad\left(K t^{\prime} 000\right)$

\begin{tabular}{|c|c|c|c|c|c|}
\hline Year & $\begin{array}{c}\text { Current value } \\
\text { of } \\
\text { mfg output }\end{array}$ & $\begin{array}{l}\text { Intermed } \\
\text { consump } \\
\text { imports } \\
\end{array}$ & $\begin{array}{l}\text { Import consump } \\
\text { for } \\
\text { cap formation }\end{array}$ & $\begin{array}{l}\text { Share } \\
\text { of (b) } \\
\text { in (a) } \\
\end{array}$ & $\begin{array}{l}\text { Share } \\
\text { of (c) } \\
\text { in (a) } \\
\end{array}$ \\
\hline 1966 & 136,899 & 50,422 & 17,721 & 36.8 & 12.9 \\
\hline 1967 & 154,936 & 53,896 & 23,600 & 34.8 & 15.2 \\
\hline 1968 & 163,851 & 57,982 & 20,009 & 35.4 & 12.3 \\
\hline 1969 & 186,892 & 60,839 & 20,932 & 32.6 & 11.2 \\
\hline 1970 & 200,681 & 72,822 & 28,712 & 36.3 & 14.3 \\
\hline 1971 & 251,145 & 95,021 & 36,203 & 37.8 & 14.4 \\
\hline 1972 & 301,862 & 85,097 & 42,481 & 28.2 & 14.1 \\
\hline 1973 & 368,340 & 112,086 & 46,145 & 30.4 & 12.5 \\
\hline 1974 & 550,591 & 209,106 & 46,585 & 38.0 & 8.5 \\
\hline $1966-68$ & 455,686 & 162,302 & 61,421 & 35.6 & 13.5 \\
\hline $1972-74$ & $1,220,794$ & 406,290 & 135,211 & 33.3 & 11.1 \\
\hline
\end{tabular}

Source: (KG5: 330)

A marked decrease in the import share of goods used by Kenyan industry would ordinarily suggest growing linkage effects to the rest of the economy and an increased impact on social and economic transformation throughout the country. However, the evidence presented above does not indicate that such is the case. In the 1966-68 period, the share of imports for capital formation accounted for only $13.5 \%$ 
of the manufacturing output, while the corresponding figure for intermediate consumption was we1! over 35\%. In the 1972-74 period, the share of intermediate consumption and capital formation were $33.3 \%$ and $11.1 \%$, respectively. The continued growth in the import bills deprives Kenya of badly needed foreign exchange earnings required for economic growth and the expansion of employment opportunities in the country.

Overall, the character of transnational subsidiary manufacturing can be seen to have restricted significantly the transformative impact on social relations from expanded industrialization in Kenya. The retarded employment growth that marked rapid industrial expansion in 1976-78 and the continued import dependence noted above for al1 Kenyan manufacturing must both be traced to the central role of transnationals in the country, given the pressure seen to be working on subsidiaries to limit their employment and linkage effects.

\section{Economic Impact of the Employment Problem}

There are many dimensions to the employment problem in Kenya. Broadly, they may be summed up as general dissatisfaction with the employment opportunities available (GR69). For those who can afford to be unemployed, this takes the form of open unemployment; for others who must work to live, low-productivity employment outside the modern sector provides temporary (and sometimes permanent) refuge for the frustrated job-seeker. This approach to the problem makes it difficult to define precisely who and how many constitute the employment problem. Despite the problem of measurement, there are some indicators of 
the magnitude of the employment problem. In Kenya, three Tripartite Agreements have provided an opportunity for those who wanted jobs in the modern sector to register. In 1964, 205,000 people registered within two weeks (35\% of modern sector employment). In 1970, over 290,000 registered within four days $146 \%$ of total modern sector and $6 \%$ of the population of working age) (GR146: 155-181). In 1979, a total of 260,000 people registered ( $28 \%$ of the formal wage employment in 1973 (GRI07). On each occasion, the books had to be closed because the authorities were overwhelmed with applications. Many of those registering for jobs already had jobs and were trying to improve their positions. Therefore, it is important to note that these figures do not indicate numbers unemployed in the economy. However, it is reasonable to argue that the very large numbers desiring modern sector jobs is an indication of how favorably these jobs are regarded. The employment problem is thus partly a reflection of the inequalities in income-earning opportunities throughout the economy. The ILO Mission to Kenya summarized the problem in this way:

Unemployment has now become chronic and intractable in nearly all developing countries. . . Part of the difficulty is structural, in the sense that many of these employment problems will not be cured simply by accelerating the rate of growth. It is increasingly clear that these employment problems are closely related to inequalities in incomes and opportunities which are not merely among their consequences but among their causes as well.

(GR69: $x i$ )

Another indicator of the magnitude of the employment problem in Kenya is the official estimate given in the latest Development Plan (KG5) (which is, to be sure, imprecise and open to a considerable margin of 
error). The figures nonetheless bring out several points. Although wage employment is relatively more important in Kenya than in many other subsaharan African countries at a comparable stage of development, it nevertheless accounted for a mere $18 \%$ of the labor force in 1978. The vast majority of Kenyans (51\%) are employed in sma11-scale agriculture. The rest are distributed in urban "informal" and rural nonfarming activities, as shown in Table XXI.

TABLE XXI

DISTRIBUTION OF ECONOMICALLY ACTIVE POPULATION Selected Years (in thousands)

\begin{tabular}{llcc} 
Estimated & $\begin{array}{c}\text { Annual \% } \\
\text { Target } \\
1978\end{array}$ & 1983 & $\begin{array}{c}\text { Increase } \\
1976-83\end{array}$ \\
\hline
\end{tabular}

Labor Force:

$\begin{array}{lllll}\text { Population }(15-59) & 6,600 & 7,070 & 8,400 & 3.5 \\ \text { (1) Labor Force (85\%) } & 5,610 & 6,000 & 7,140 & 3.5\end{array}$

Employment:

$\begin{array}{lrrrr}\text { Modern Sector } & 975 & 1,000 & 1,250 & 4.6 \\ \text { Small-scale agri } & 2,665 & 2,810 & 3,210 & 2.7 \\ \text { Pastoralists } & 390 & 410 & 470 & 2.7 \\ \text { Rural non-farm } & 990 & 1,100 & 1,460 & 5.7 \\ \text { Urban-informal } & 125 & 140 & 195 & 6.5 \\ \text { Total employment } & 5,085 & 5,460 & 6,585 & 3.8 \\ \text { idual (1 less 2) } & 525 & 540 & 555 & \\ \text { Sidual as \% of } & & & & \end{array}$

Source: (KG5: 34, Table 2.1) 
According to the figures, open unemployment is estimated for 1978 at $9 \%$ of the total labor force, declining since 1976 and projected to fall further during the plan period. Given the present economic crisis and chronic balance-of-payments difficulties, it is unreasonable to expect that such a target will be achieved.

The estimated $9 \%$ open unemployment $(540,000$ people) no doubt represents a major blemish on the economy. Nevertheless, from the perspective of the overall development problem with which Kenya is confronted, the problem of open unemployment, visible as it is in the urban areas and among school leavers, is of smaller magnitude than the problem of the working poor (GR69: 35). The plan draws a poverty line at a household income of less than K.shs. 3,000/-per annum and identifies five distinct poverty groups, shown below in Table XXII, which is taken from the 1979-83 Development Plan.

TABLE XXII

POVERTY GROUPS

\# of families Average household income (K. shs.)

(a) Small farmers who derive income from land

618,500

1,650

(b) Landless, squatters, rural labor, with no land

$410,000 \quad 2,250$

(c) Pastoralists in a nomadic setting (livestock income)

195,000

2,000

(d) Handicapped adults

140,000

1,500

(e) Urban poor in self or wage employment

40,500

2,400

Totals

$1,404,000$

1,880

Source: (GR69, 22, 35) 
The Plan estimates that these families have a total population of $6,073,000$, which is $49 \%$ of the nation's total population. This . information hides the sizeable differences in income among households. If a line is drawn at an annual income per adult of below K.shs. 500/-, approximately $45 \%$ of the total small-holder population can be classified as living in poverty. Given the problem of measurement and a lack of reliable data, it is difficult to determine the total volume and pattern of employment in Kenya.

In the same fashion, estimating the exact volume of urban unemployment has not been an easy task. The ILO Mission to Kenya (GR69: 10) estimated an urban unemployment of $8-15 \%$ (or a weighted average of $11.5 \%$ ). To this must be added the urban working poor (estimated at 50,000) and school leavers totaling over 300,000 (KG5: 48). The problem is thus much more serious than it superficially appears to be. As long as there are imbalances in the economy, there will also be high unemployment.

Trends in Wage Employment. The only component of employment for which a reasonably accurate statistical series exists is the wage employment in the modern sector. Table XXIII on the following page shows the numbers employed in the modern sector growing from 826,000 in 1974 to $1,005,000$ in 1980. During this period, employment in the public sector grew at an annual rate of $6.1 \%$ This is indicative of the fact that the public sector is the largest employer in the modern sector. The growth in agriculture and forestry stagnated, which explains why the private sector had a nominal growth rate due to linkages the sector has with the rest of the economy. Overal1, the annual growth 
rate for both the private and public sectors amounted to an average of $3.1 \%$ over this period, barely matching the annual population growth rate of $3.5 \%$ per year. The most successful period, in terms of modern sector job creation, was 1968-74, with an annual rate of increase of $5.3 \%$. This is attributed to the rapid Africanization program during that period and the First Tripartite Agreement which contributed 30,000 new jobs.

TABLE XXIII

SUMMARY OF WAGE EMPLOYMENT BY SECTOR, 1974-80

(IN THOUSANDS)

\begin{tabular}{|c|c|c|c|c|c|c|c|c|}
\hline Sector & 1974 & 1975 & 1976 & 1977 & 1978 & 1979 & $1980^{\star}$ & $\begin{array}{c}\% \\
\text { annual } \\
\text { growth } \\
\text { rate } \\
\end{array}$ \\
\hline Public & 330.1 & 342.4 & 356.4 & 376.4 & 390.0 & 424.7 & 471.5 & 6.1 \\
\hline Private & & & & & & & & 1.1 \\
\hline $\begin{array}{l}\text { Commerce/ } \\
\text { Industry }\end{array}$ & 282.5 & 280.9 & 303.4 & 320.1 & 332.6 & 353.7 & $N / A$ & \\
\hline $\begin{array}{l}\text { Agri/ } \\
\text { Forestery }\end{array}$ & 213.7 & 195.8 & 197.7 & 206.4 & 189.0 & 193.9 & $N / A$ & \\
\hline Totals & 826.3 & 819.1 & 857.5 & 902.9 & 911.6 & 972.3 & 1005.8 & 3.1 \\
\hline
\end{tabular}

Source: (KG7, 1980, Table 237)

It should be noted at the outset that the published data on employment (which, of course, refers to wage employment in the modern sector alone) may give a seriously misleading picture of the true position of modern sector employment. This is particularly true since wage employment in agriculture and forestry apparently expanded at a relatively 
higher rate, at least until 1975, than employment in the manufacturing sector. On the whole, however, the public sector is the major industry in Kenya and has grown at a much faster rate than has employment in the private sector.

Table XXIV provides a much more accurate picture of the contribution of the modern sector, particularly the manufacturina industry to employment opportunities in Kenya.

TABLE XXIV

SUMMARY OF MANUFACTURING OUTPUT AND EMFLOYMENT GROWTH, 1971-79

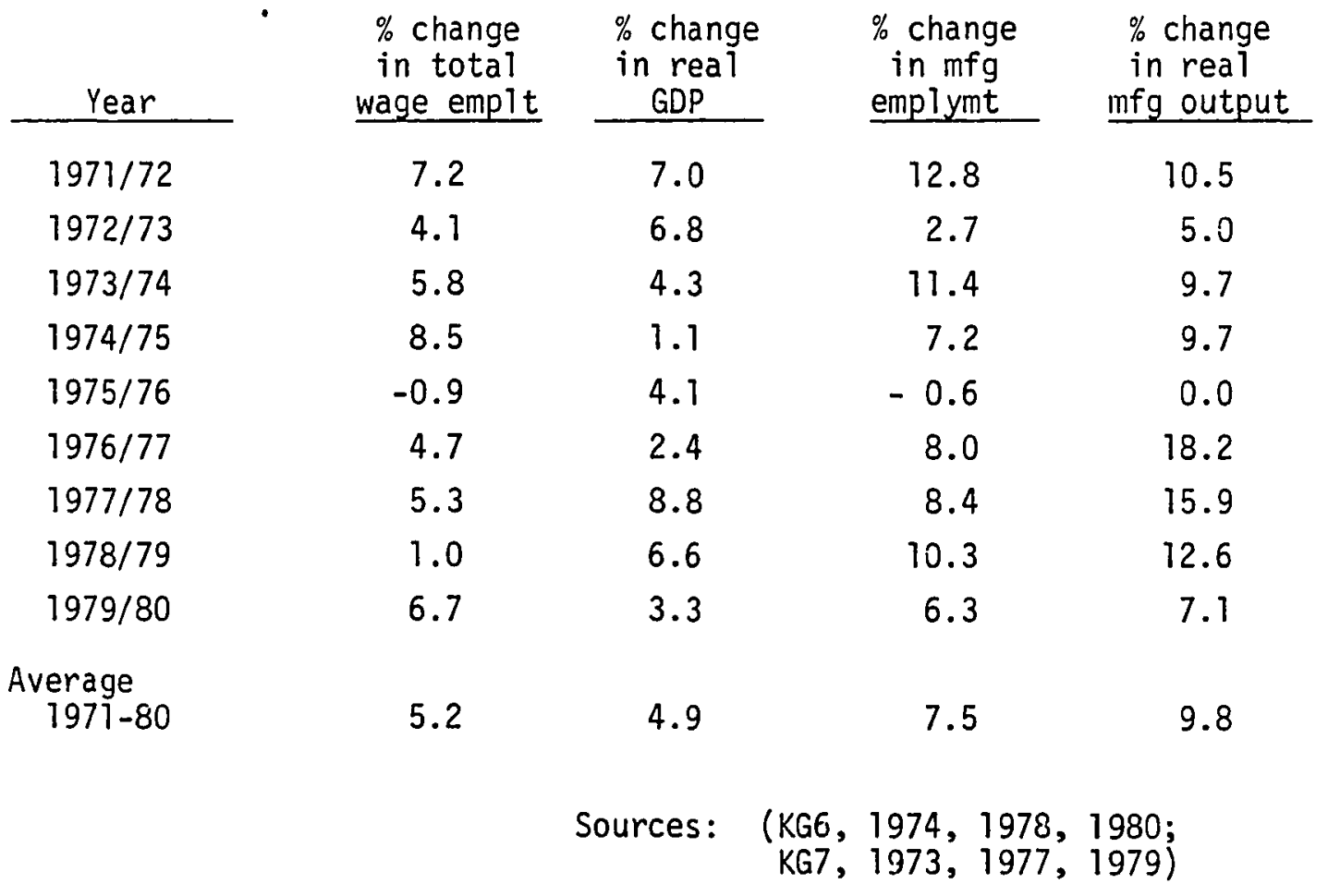

First, there has been a distinct slowdown in wage employment growth since 1974; the average annual increase in the 1975-79 period has been $4.2 \%$, compared with $6.4 \%$ in the 1971-74 period. The spectacular 
increase in 1979 was due to the Third Tripartite Agreement, which attempted to increase wage employment by $10 \%$. If the pattern of the earlier government intervention of this sort (in 1970-71) is reproduced, then the 1979 increase simply represents an acceleration of hiring intentions, followed by a significantly lower-than-average increase in the 1980 data (as was also the case for 1972). Secondly, it is significant that although there has not been a great divergence among rates of change in overall wage employment and in GDP in the country, there has in recent years been much more divergence in the direction of lower rates of employment growth in the manufacturing sector itself. For example, in the period 1971-79, the average annual growth in total wage employment was $5.2 \%$ and in GDP $4.9 \%$, while in manufacturing employment growth averaged $7.5 \%$ compared with $9.8 \%$ for manufacturing output. That is, the expansion of production has not been matched by a proportional expansion of employment opportunities in manufacturing. Thirdly, it should be stressed that manufacturing employment growth has proven to be relatively limited in recent years, despite very dramatic increases in output in the manufacturing sector: $18 \%, 16 \%$, and $13 \%$ in 1976, 1977, and 1978, respectively.

Employment Effects of Foreign Investment. Fairly comprehensive data exist on total employment and wage bills in industry, particularly in large-scale enterprises. However, published data draws no distinction between the nationality of the investor, and it is therefore impossible to estimate the employment generated by foreign investment, on the basis of this data. However, using existing data on ownership patterns in large scale industry and in all tourism, Kaplinsky (GR77) estimated the 
numbers employed in different types of firms, incorporating data from the Central Bureau of Statistics concerning the broad size groups each firm (see Table XXV). In combining this data, he estimated the total employment in foreign manufacturing firms to be 90,386 for 1976 . This figure represents only $11 \%$ of the total wage employment in the modern sector for 1976. Considering the fact that foreign ownership is concentrated in the 25-50, 50-95, and 95-100 percentiles of ownership groupings, the actual contribution of foreign investment to employment becomes even less significant. On the basis of minimum and maximum assumptions, Kaplinsky estimated that the share of multinational enterprises in total manufacturing employment was $30-35 \%$, or close to 30,000 jobs for 1976 . In short, foreign investment contributed to less than $3 \%$ of the total wage employment in the country in 1976. Considering all the incentives accorded to foreign investment, its contribution to the development of Kenya has been negligible.

Regional Distribution of Wage Employment. The distribution of formal sector employment in Kenya is uneven, as shown in Table XXVI. The dominance of Nairobi has just been maintained, at $27 \%$ of total modern sector employment, and additional employment in Nairobi accounted for $26 \%$ of the national increase in 1967-73. The same is true for Mombasa, incorporated in the Coast Province figure. Formal sector employment opportunities in Nyanza and Western Province, where the need is greatest, have expanded partly due to the growth of sugar production.

However, the share of employment in Nyanza and Western Province 
TABLE XXV

ESTIMATE OF TOTAL EMPLOYMENT IN LARGE SCALE MANUFACTURING BY SECTOR AND FOREIGN OWNERSHIP GROUPINGS, (1976)

\begin{tabular}{|c|c|c|c|c|c|c|c|c|}
\hline \multirow[b]{2}{*}{ Sector } & \multicolumn{8}{|c|}{ Foreign Ownership Grouping (\%) } \\
\hline & & 0 & $1-10$ & $10-25$ & $\underline{25-50^{\star}}$ & $50-95^{\star}$ & $95-100^{\star}$ & Total \\
\hline & ISIC & & & & & & & \\
\hline Food, beverages & 31 & 10,501 & 1,391 & 3,213 & 288 & 4,795 & 4,747 & 24,934 \\
\hline Textiles, leather & 32 & 7,049 & 815 & 1,534 & 1,822 & 7,384 & 3,213 & 21,817 \\
\hline Wood, furniture & 33 & 6,713 & 0 & 0 & 0 & 0 & 719 & 7,432 \\
\hline Paper, printing & 34 & 3,932 & 0 & 0 & 0 & 1,534 & 432 & 5,898 \\
\hline Chemicals, rubber & 35 & 1,439 & 671 & 288 & 1,103 & 1,247 & 5,610 & 10,357 \\
\hline Pottery, glass & 36 & 2,014 & 144 & 288 & 1,534 & 2,206 & 0 & 6,186 \\
\hline Basic metals & 37 & 575 & 0 & 0 & 0 & 0 & 575 & 1,151 \\
\hline $\begin{array}{l}\text { Fabricated metal } \\
\text { products }\end{array}$ & 38 & 4,747 & 0 & 350 & 3,836 & 288 & 2,350 & 11,892 \\
\hline Other manufacturing & 39 & 575 & 0 & 0 & 144 & 0 & 0 & 719 \\
\hline Totals & & 37,545 & 3,021 & 5,994 & 8,727 & 17,454 & 17,646 & 90,386 \\
\hline
\end{tabular}

(*) signifies areas of foreign concentration.

Source: (GR77: 41) 


\section{TABLE XXVI}

CHANGE IN FORMAL SECTOR EMPLOYMENT, ALL SECTORS

$(1967-78)$

\begin{tabular}{|c|c|c|c|c|c|c|c|}
\hline \multirow[b]{2}{*}{ Province } & \multicolumn{4}{|c|}{ Numbers Employed } & \multicolumn{2}{|c|}{$\begin{array}{c}\text { Increase in } \\
\text { \#'s emp loyed } \\
1967-78\end{array}$} & \multirow{2}{*}{$\begin{array}{c}\text { Share of increase } \\
\text { in \#'s employed } \\
1967-78 \\
\% \\
\end{array}$} \\
\hline & $\#$ & $\%$ & $\#$ & $\%$ & $\#$ & $\%$ & \\
\hline Nairobi & 163,692 & 27.4 & 244,431 & 26.8 & 80,739 & 49.2 & 25.7 \\
\hline Central & 87,834 & 14.7 & 137,612 & 15.1 & 49,778 & 56.7 & 15.8 \\
\hline Coast & 77,763 & 13.0 & 122,678 & 13.5 & 44,915 & 57.8 & 14.3 \\
\hline Eastern & 36,572 & 6.1 & 71,009 & 7.8 & 34,437 & 94.2 & 11.0 \\
\hline $\mathrm{N}$ Eastern & 2,232 & 0.4 & 4,941 & 0.5 & 2,709 & 121.4 & 0.9 \\
\hline R Valley & 167,926 & 28.1 & 221,133 & 24.3 & 53,207 & 31.7 & 16.9 \\
\hline Nyanza & 43,458 & 7.3 & 67,301 & 7.4 & 23,843 & 54.9 & $7.6)$ \\
\hline Western & 17,892 & 3.0 & 42,456 & 4.7 & 24,564 & 137.3 & $7.8 j$ \\
\hline Totals & 597,369 & 100.0 & 911,561 & 100.0 & 314,192 & 52.6 & 100.0 \\
\hline
\end{tabular}


combined still compares unfavorably with, for example, Central Province: $10.3 \%$ compared with $14.7 \%$ in 1967 and $12.1 \%$ compared with $15.1 \%$ in 1978 , considering also the additional opportunity created for the latter by the proximity of Nairobi. Similarly, the $15.4 \%$ share of the two provinces in the 1967-78 increase, less than that of Central Province, is not sufficient to have led to any significant change in balance. As in the case of Central Province, increases in employment in Eastern Province will be supplemented by additional opportunities in Nairobi and the adjacent Coast Province, embracing Mombasa.

Table XXVII shows clearly the domination of Nairobi and Mombasa. Together they account for $73 \%$ of wage employment in main towns in 1978. Outisde these two cities, there are no other important centers--the largest, Nakuru, stil1 accounted for only $3.7 \%$ of the employment in 1978. Despite the urgency of expanding urban employment opportunities in the overpopulated regions of Western Kenya, the Kisumu share was only $3.5 \%$.

Looking specifically at manufacturing, the position is much the same. The two major cities, Nairobi and Mombasa, accounted for 69\% of the total manufacturing employment in the main towns during 1978. The Thika municipality emerged as another potentially important center, with $10 \%$ manufacturing employment in 1978 . This is due to the proximity Thika to the major city of Nairobi. On the whole, the manufacturing employment distribution data reflects the industrial location policy of the government, which tends to favor Nairobi and Mombasa. It is reasonable to conclude that a significant impact on the distribution of employment opportunities in manufacturing can only be made by 
attempting to influence the location of plants. In the absence of such a policy, rural to urban migration, particularly among the educated, will continue, further exacerbating the problem of urban unemployment in Nairobi and Mombasa.

\section{TABLE XXVII}

DISTRIBUTION OF WAGE AND MANUFACTURING EMPLOYMENT, BY MAIN TOWNS, 1978

\begin{tabular}{|c|c|c|c|c|}
\hline \multirow[b]{2}{*}{ Ma in Towns } & \multicolumn{2}{|c|}{$\begin{array}{c}\text { Wage } \\
\text { Employment }\end{array}$} & \multicolumn{2}{|c|}{$\begin{array}{l}\text { Manufacturing } \\
\text { Employment }\end{array}$} \\
\hline & $\#$ & $\%$ & $\#$ & $\%$ \\
\hline Nairobi & 244,431 & 53.8 & 48,707 & 50.2 \\
\hline Mombasa & 86,276 & 19.0 & 17,947 & 18.5 \\
\hline Nairobi/Mombasa & 330,707 & 72.8 & 66,654 & 68.8 \\
\hline Nakuru & 16,710 & 3.7 & 5,374 & 5.5 \\
\hline Kisumu & 15,980 & 3.5 & 3,374 & 3.5 \\
\hline Eldoret & 11,125 & 2.4 & 4,803 & 5.0 \\
\hline Thika & 12,373 & 2.7 & 9,440 & 9.7 \\
\hline Other towns & 67,253 & 14.9 & 7,309 & 7.5 \\
\hline Totals & 454,148 & 100.0 & 96,949 & 100.0 \\
\hline
\end{tabular}

\section{INTERNATIONAL TRADE}

Kenya, like most other developing nations, relies on nonmineral primary product exports for a large percentage of its foreign exchange earnings. In 1979, coffee and tea combined made up $45 \%$ of the total exports. In addition to its export dependence, Kenya relies even more on the importation of raw materials, machinery, capital goods, intermediate producer goods, and consumer products to fuel its industrial 
expansion and to satisfy the rising consumption aspirations of its people. In recent years, import demands have exceeded the capaicty to generate sufficient revenues from the sale of exports. This has led to chronic trade deficits which affect Kenya's balance-of-payments position.

Table XXVIII indicates that between 1970 and 1979, imports have risen at a faster rate than exports during the same period; and this trend has resulted in a widening trade deficit. In 1979, earnings from

TABLE XXVIII

SUMMARY OF KENYA'S EXTERNAL TRADE, 1970 and 1975-79 (Kt million)

\begin{tabular}{|c|c|c|c|c|c|c|c|}
\hline $\begin{array}{l}\text { Type of } \\
\text { Trade }\end{array}$ & 1970 & 1975 & 1976 & 1977 & 1978 & 1979 & $\begin{array}{l}\text { Growth Rates } \\
1970-79, \text { PA }\end{array}$ \\
\hline Exports & 108.8 & 238.0 & 345.1 & 501.8 & 395.7 & 412.8 & 15.9 \\
\hline Imports & 158.0 & 362.6 & 406.9 & 531.4 & 661.2 & 619.7 & 16.4 \\
\hline $\begin{array}{l}\text { Trade } \\
\text { Balance }\end{array}$ & -49.2 & -124.6 & -61.8 & -29.6 & -265.5 & -206.9 & 17.3 \\
\hline
\end{tabular}

exports covered only $67 \%$ of the cost of imports, and the trade deficit was at a high level of Kt 206.9 million. The trade deficit was significantly less in 1976 and 1977 than in previous years due to a high foreign exchange earning from coffee and tea. But during 1978 and 1979, the deficit again rose due to strong external shocks as a result of the latest round of petroleum price increases and declining coffee prices in the international market. The balance-of-payments and income effects of these declines were compounded by poor weather 
affecting coffee and maize production. As a result, GDP growth slowed to $4.2 \%$ in 1979 and to an estimated $2.4 \%$ in 1980 (GR152). The increase in petroleum prices combined with additional food imports resulted in a $25 \%$ rise in the value of imports in 1980. While exports rose by $16 \%$, this was not sufficient to prevent a rise in the current account deficit to almost $\$ 900$ million and, despite increased external borrowing, a decline of $\$ 198$ milition in foreign exchange reserves (GRI69). In short, the economy does not have the export capacity to sustain the high level of imports which accelerated growth and investment setoffs, and this regularly chokes off the accumulation process and hence, the expansion of employment opportunities.

\section{Exports}

Kenya's exports are highly concentrated by commodity, which is easily proven by the statistics which show that three commodities provide more than half of all exports (see Table XXIX below).

TABLE XXIX

SUMMARY OF TOTAL EXPORTS*, 1975-79

(PERCENTAGE SHARES)

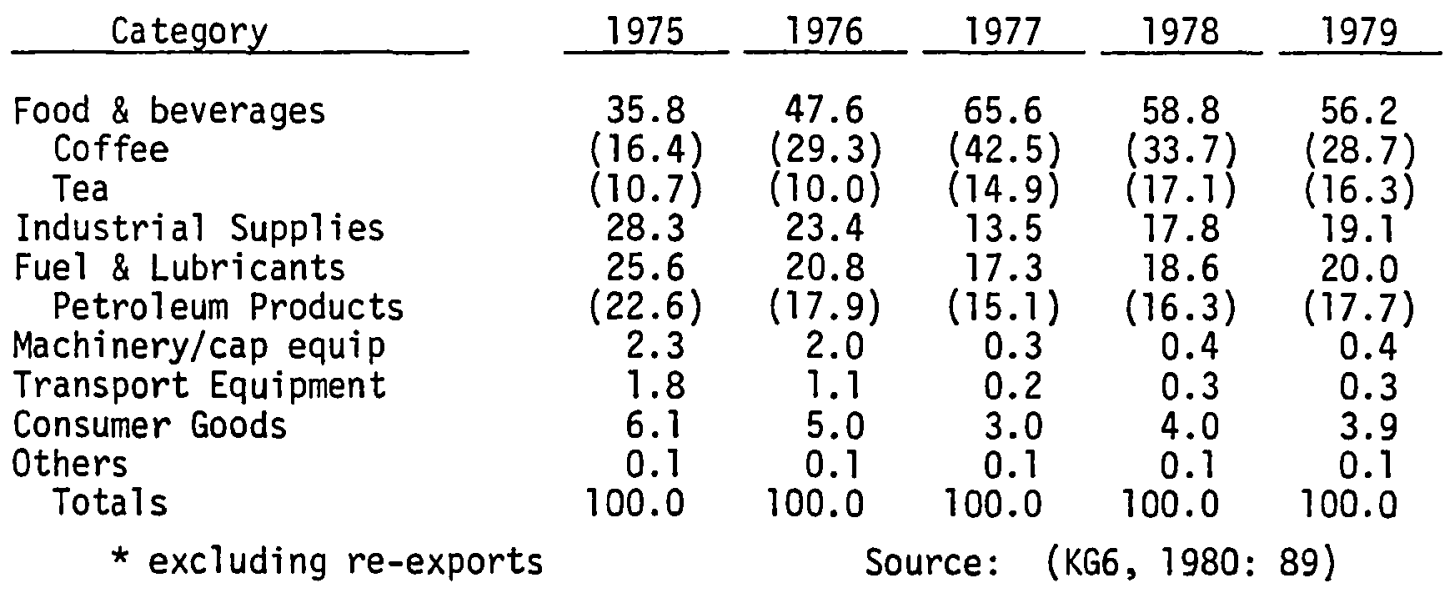


Before 1964, sisal was the third largest export product. In 1979, coffee and tea combined made up $45 \%$ of total exports. These two products are dependent on world market forces entirely outside Kenya's control.

It has already been remarked that price increases have been the major reason for the increase in the value of most exports, particularly coffee and tea. However, there have also been some large increases in the quantity exported. A good example are the coffee and tea industries. The volume of tea exported rose from 16,500 tons in 1964 to over 70,000 in 1977 and fell to 64,000 in 1979 due to a decline in the price of tea. The predominance of coffee export in 1977 was much more the result of the sharp increase in price; nevertheless, 204,336 tons of coffee were exported in 1977 compared with 42,000 tons in 1974. In 1979, the volume declined to 110,673 , due to a decline in the world price for coffee. Here the dependence on agriculture merged with the dependence on foreign trade.

It is important to observe certain trends in the industrialized capitalist countries of the West who are Kenya's major trading partners. For example, among these trading partner countries, the demand for most primary products does not increase in per capita income. Production of artificial substitutes--the result of technological changes--also partly accounts for a slackening in the demand for primary products. In addition, certain policy measures in the industrialized countries hinder increased exports from primary producing countries. Among such measures are subsidization of domestic raw materials and heavy import duties and tariffs against raw materials 
in developing countries.

A certain limitation of Africa's export orientation has to do with the lack of flexibility and economic diversity in an economy dependent on raw materials. For example, when the price of coffee falls on the world market, it is not possible, in the short term, to move resources out of coffee into other lines of production. Another limitation has to do with the concept of linkages--both forward and backward--i.e., the export industry does not generate enough domestic demand for investment.

An examination of the direction of Kenya's exports provides yet another weakness. The main buyers of Kenya's exports are advanced capitalist countries in Europe, North American, and Japan. The instability and the unplanned nature of the capitalist markets, coupled with the competitive efforts of other primary producers, renders the dependence on such products extremely dangerous.

Table XXX shows that between $1970-79$, nearly $50 \%$ of Kenya's exports were destined to Western Europe and North America. In 1979, the United Kingdom and West Germany combined accounted for 30\% of Kenya's exports (KG7, 1980). Although trade with Africa accounted for $24 \%$ of exports in 1979, the trend has been declining since 1977, particularly after the breakup of the East African Common Market. As the main agricultural exports do not go to the East African countries, manufacturing accounted for $90 \%$ of Kenya's export to Tanzania and $84 \%$ of its exports to Uganda (KG7, 1978). It is clear that continued dependence of African economies on the production of raw materials for export is detrimental to their long-term development. Thus, any 
developmental policy that promotes only the exploitation of primary products to increase exports and obtain tax revenue for developmental expenditure is not a viable long-term policy.

TABLE $X X X$

DESTINATIONS OF KENYAN EXPORTS

1970-1979

Percentage of Total Exports to:

\begin{tabular}{|c|c|c|c|c|}
\hline Year & $\begin{array}{l}\text { Western } \\
\text { Europe }\end{array}$ & $\begin{array}{l}\text { North and South } \\
\text { America } \\
\end{array}$ & Africa & $\begin{array}{r}\text { Far East \& } \\
\text { Australasia } \\
\end{array}$ \\
\hline 1970 & $34.9 \%$ & $8.4 \%$ & $39.4 \%$ & $6.9 \%$ \\
\hline 1971 & 31.1 & 5.8 & 42.6 & 7.6 \\
\hline 1972 & 39.4 & 6.0 & 36.3 & 7.6 \\
\hline 1973 & 38.4 & 7.5 & 34.5 & 10.2 \\
\hline 1974 & 36.0 & 5.5 & 34.8 & 10.3 \\
\hline 1975 & 33.4 & 7.7 & 34.4 & 9.1 \\
\hline 1976 & 43.4 & 8.8 & 26.3 & 8.2 \\
\hline 1977 & 55.4 & 7.1 & 19.8 & 5.4 \\
\hline 1978 & 51.2 & 6.0 & 21.0 & 6.8 \\
\hline 1979 & 48.3 & $N / A$ & 24.0 & 7.6 \\
\hline
\end{tabular}

Imports

Whereas in general the relative share of the various categories of imports remained unchanged in 1979, there was a notable increase in the share of the value of fuels and lubricants and nonfood industrial supplies, while the shares of the values of certain other categories declined. Since the sharp rise in the price of oil in late 1973, a substantial share of Kenya's imports is now tied to the 
importation of petroleum. Kenya, with its auto-owning bourgeoisie and expatriate population, is particularly vulnerable in this regard, as oil imports account for one-fifth of the country's imports (see Table XXXI).

TABLE XXXI

SUMMARY OF TOTAL IMPORTS, $1975-79$

(PERCENTAGE SHARES)

\begin{tabular}{|c|c|c|c|c|c|}
\hline Category & 1975 & 1976 & 1977 & 1978 & 1979 \\
\hline Food \& Beverages & 5.9 & 6.5 & 5.2 & 5.8 & 5.3 \\
\hline $\begin{array}{l}\text { Industrial Supplies } \\
\text { (nonfood) }\end{array}$ & 29.0 & 30.6 & 30.3 & 27.2 & 29.0 \\
\hline Fuets \& Lubricants & 26.4 & 25.5 & 22.0 & 17.8 & 23.7 \\
\hline Machinery/cap equip & 17.0 & 17.8 & 19.4 & 21.3 & 20.2 \\
\hline Transport Equipment & 12.9 & 10.8 & 14.3 & 19.2 & 15.4 \\
\hline Consumer Goods & 8.6 & 8.7 & 8.7 & 8.4 & 6.3 \\
\hline Others & 0.2 & 0.2 & 0.1 & 0.3 & 0.1 \\
\hline Totals & 100.0 & 100.0 & 100.0 & 100.0 & 100.0 \\
\hline
\end{tabular}

Imports of nonfood industrial supplies remained almost unchanged in 1979, though there was more emphasis on imports of processed supplies than on primary goods. The most noticeable change was the heavy decline in the value of imported transport equipment, particularly imported passenger vehicles due to government restrictions to save foreign exchange. Imports of nonfood consumer goods also fell sharply as the government banned a number of consumer goods from Nairobi shops. The restrictions imposed since 1978 clearly show the vulnerability of the Kenyan economy and the worsening foreign exchange situation. 
Balance of Payments

The table below summarizes Kenya's balance-of-payment position regarding Current Accounts, Capital Accounts, and Cash Accounts.

TABLE XXXII

SUMMARY OF KENYA'S BALANCE OF PAYMENTS

(MILLIONS OF KENYAN POUNDS)

$1971 \quad 1973 \quad 1975 \quad 1977 \quad 1978 \quad 1979$

A. Current Accounts

$\begin{array}{lllllll}\text { Imports } & 196.2 & 219.0 & 342.7 & 535.1 & 723.3 & 665.0\end{array}$

$\begin{array}{lllllll}\text { Exports } & 104.9 & 164.5 & 212.7 & 470.9 & 366.5 & 380.3\end{array}$

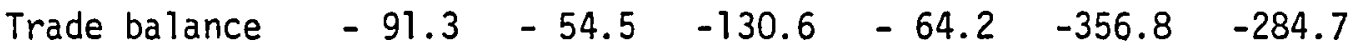

$\begin{array}{lllllll}\text { Freight, Transp, } & 39.1 & 39.0 & 88.1 & 123.3 & 132.2 & 130.7\end{array}$ Travel

Invest/income $\quad-8.8 \quad-35.7 \quad-36.5 \quad-59.5-55.0 \quad-49.2$

$\begin{array}{lllllll}\text { Govt transfer } & 20.9 & 7.5 & 7.5 & 3.5 & 32.3 & 28.3\end{array}$

$\begin{array}{lllllll}\text { Invisible bal } & 51.5 & 7.7 & 57.5 & 88.3 & 104.3 & 106.4\end{array}$

$\begin{array}{lllllll}\text { Current balance } & -39.9 & -46.8 & -76.7 & 24.1 & -252.5 & -178.3\end{array}$

B. Capital Account

$\begin{array}{lllllll}\text { Long term inflow } & 15.2 & 53.1 & 62.9 & 90.4 & 171.0 & 250.9\end{array}$

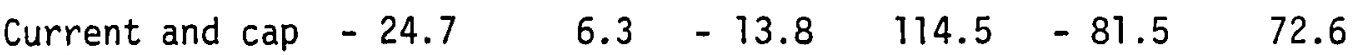

balance

C. Cash Account

$\begin{array}{lllllll}\text { External reserves } & 51.8 & 76.3 & 70.6 & 208.6 & 133.3 & 176.8\end{array}$

Sources: (KG6, KG7, various years)

This table indicates that, with the temporary exception of 1977, Kenya runs a deficit on Current Accounts, i.e., on transactions involving goods and services. Despite this fact, the country has consistently been able to secure net inflows of long-term capital from the rest of the world, 
inflows that have become substantial since 1974. The net total of the Current and Long Term Capital Accounts is then combined into the Basic Balance, which is the best single indicator of the health of Kenya's payment position. In three of the six sample years recorded, there was a surplus in the Basic Balance, reflecting a generally satisfactory situation. The years 1971, 1975, and 1978 were the main exceptions. A generally satisfactory situation is also revealed in the figures on the country's foreign exchange reserve.

Kenya's growth performance since 1974 has been vulnerable to swings in its international terms of trade. The escalation of oil prices and the associated world inflation imposed a serious deficit on Kenya with little warning. The economy accelerated once again in 1976-77 due to the "coffee boom" following frost damage in Brazil and decelerated after 1978 when coffee prices declined to more normal levels. At the same time, the import bill rose (it increased by $80 \%$ between 1975 and 1978). This combination resulted in a huge current deficit of Kt 252 million in 1978, and the foreign exhcange reserve dwindled rapidly to about half of the peak of 1977. During 1978-80, Kenya again experienced strong external shocks as a result of the latest round of petroleum price increases and declining coffee prices. As a result, GDP growth slowed to $4.2 \%$ in 1979 and to an estimated $2.4 \%$ in 1980 . Kenya's balance of payment constraints will continue in the short run. Factors outside Kenya's control, such as oil price increases, reduced demand for Kenya's export commodities, and slow economic recovery in the industrialized countries are having a significant adverse impact on the Kenyan economy. The balance-of-payment problem is indicative of the 
rough times ahead for the Kenyan economy and the gloomy employment prospect for thousands of school leavers each year.

FOREIGN AID

In the face of this combination of volatile export earnings and recurrent foreign exchange problems, Kenya has had to rely on external government borrowing. The deficits on external trade have been covered partiy by earnings from tourism and to an increasing extent by grantsin-aid from multilateral and bilateral agencies. As can be seen from Table XXXIII, in the early years of independence (1963-1969), the United Kingdom was overwhelmingly the most important source of financial aid. Between 1963-69, over $80 \%$ of all aid was from Britain; by 1975, the United Kingdom accounted for less than $30 \%$ of all disbursements. Since the mid-1970's, the World Bank and the Scandinavian countries have taken on the role of large donors. For example, in 1980,63\% of a 11 loans came from the International Monetary Fund (IMF) and the World Bank. The Scandinavian countries accounted for $30 \%$ of all grants in 1980.

So far, Kenya has received 36 World Bank loans and 33 credits from the International Development Agency (IDA) amounting to US\$1,291.1 million. Loans given to Kenya carry a high interest rate. IDA credits have only a $\frac{1}{4} \%$ service share, while IBRD loans to Kenya have an interest rate ranging from 7 to $8 \frac{1}{2} \%$. In fact, the World Bank loans, though increasingly taking a big proportion of Kenya's total foreign aid, have been the most expensive elements of aid to the country. World Bank (IBRD) loans to Kenya range from 10 to 30 years for repayment, including 
TABLE XXXIII

ECONOMIC AID TO KENYA, 1963-1980

(KL OOO')

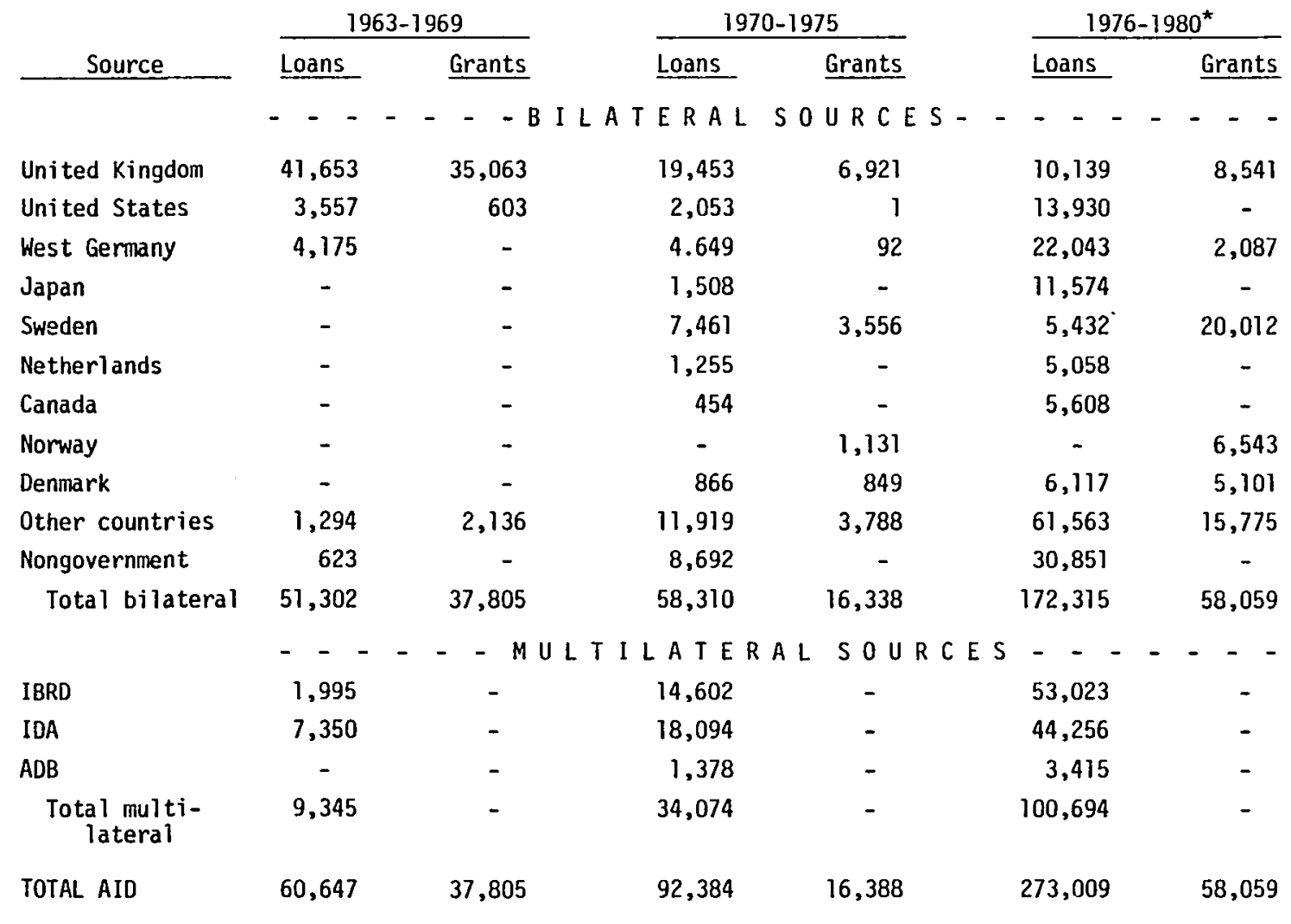

* 1980 figures for grants are estimates given in (KG7, 1980)

Sources: (KG6, 1964-1980: KG7, 1964-1980) 
a seven years grace period, while those of its affiliates (IDA) require 50 years repayment and 10 years grace. Other donors vary from 5 years to 50 years of repayment plus some grace period (PI 17 ). The obvious implication of heavy borrowing is a proportionately heavy debt burden.

Table XXXIV indicates that, as of June 1979, the main countries to which Kenya owed a debt included West Germany, the USA, and Japan. The United Kingdom had abolished debts owed by Kenya and now provides aid on a grant basis only. Among international organizations, the largest debt was owed to the World Bank and its subsidiary, the International Development Agency.

In general, debt servicing charges rise as the total debt rises. External net servicing charges jumped to $\mathrm{Kt} 25.5$ million in 1979 (from Kt 8.6 million in 1974). There was a decline in the debt service charges on external debts in 1979 because of the abolition by the United Kingdom of outstanding Kenyan debts. As a result, the debt service ratio as a proportion of earnings from exports of goods and services fell from a high of $5.5 \%$ in 1978 to $4.4 \%$ in 1979 . In real monetary terms, interest payments siphoned off $\$ 18$ of every $\$ 100$ Kenya earned on exports (Wa11 Street Journal, Apri1 11, 1983: 18). The summary of external debt charges related to exports is capsulized in Table $X X X V$.

The influence of aid on national policymaking structures is very strong and has been the subject of various studies (GR63; GR159). Technical assistance personnel occupy crucial decisionmaking positions in all Kenyan governmental ministries. The expatriates are not only 
TABLE XXXIV

SUMMARY OF KENYA'S OUTSTANDING DEBTS 1974-79 (MILLIONS OF KL)

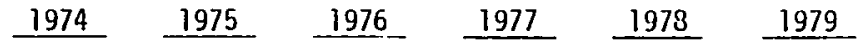

Bilateral Debts:

United Kingdom

United States

West Germany

Japan

Sweden

The Netherlands

Denmark

Other

Totals

$\begin{array}{rrrrrc}47.0 & 43.0 & 41.0 & 37.0 & 37.0 & - \\ 14.0 & 16.0 & 18.0 & 20.0 & 15.0 & 16.0 \\ 6.0 & 14.0 & 16.0 & 21.0 & 30.0 & 33.0 \\ 1.0 & 3.0 & 7.0 & 11.0 & 14.0 & 14.0 \\ 7.0 & 10.0 & 12.0 & 12.0 & - & - \\ 2.0 & 5.0 & 5.0 & 6.0 & 9.0 & 7.0 \\ 1.0 & 2.0 & 3.0 & 4.0 & 7.0 & 7.0 \\ 4.0 & 5.0 & 7.0 & 10.0 & 22.0 & 36.0 \\ 82.0 & 98.0 & 109.0 & 121.0 & 134.0 & 113.0\end{array}$

Multilateral Debts:

IBRD

IDA

African Devt Bank

Other

Totals

Total External Debt

Annual External Debt Charge *

* (KG6, 1980: 77)

$\begin{array}{rrrrrr}11.0 & 16.0 & 39.0 & 42.0 & 46.0 & 55.0 \\ 21.0 & 28.0 & 38.0 & 41.0 & 47.0 & 56.0 \\ 2.0 & 2.0 & 2.0 & 3.0 & 3.0 & 3.0 \\ - & 1.0 & 2.0 & 2.0 & 9.0 & 30.0 \\ 34.0 & 47.0 & 81.0 & 88.0 & 105.0 & 144.0 \\ 116.0 & 145.0 & 190.0 & 209.0 & 239.0 & 257.0 \\ 8.0 & 10.0 & 12.0 & 15.0 & 31.0 & 31.0\end{array}$

Source: (KG7, 1980, Table 228 (5)) 
TABLE $X X X V$

SUMMARY OF EXTERNAL DEBT CHARGE RELATED TO EXPORT 1974-1979

$$
1974 \quad \underline{1975} \quad \underline{1976} \quad \underline{1977} \quad 1978 \quad \underline{1979}
$$

Debt Service Charge on External Debt (Kt million)

Exports of Goods \& Services

External Debt Service Charge as \% of Exports $\begin{array}{llllll}8.6 & 10.1 & 12.0 & 14.8 & 31.2 & 25.5\end{array}$

$\begin{array}{llllll}357.2 & 356.9 & 471.7 & 650.2 & 566.8 & 580.4\end{array}$

$\begin{array}{llllll}2.4 & 2.8 & 2.5 & 2.3 & 5.5 & 4.4\end{array}$

Source: (KGō, 1980, Table 6.12)

involved in devising policies and development plans, but also in identifying potential sources of aid and negotiating with relevant donors. Once foreign aid is negotiated and agreed upon between donor and Kenyan government representatives (often the technical assistance personnel), its conditions, objectives, and implications are never discussed by relevant political institutions such as the Parliament. Because funds must be spent as quickly as possible before the expiration of the negotiated period, there is seldom time for discussions and debates about the real aims and implications of aid for national development. Unspent aid funds are regarded as a reflection of inefficiency or bad management on the part of the recipient country, so virtually all aid is handled by technical assistance personnel whose chief function is to ensure that all disbursed aid is spent.

Multilateral aid agencies such as the World Bank probably have more influence on policy matters than bilateral donors inasmuch as 
they presently contribute the largest proportion of aid. The World Bank, for instance, claims that its aid and aid projects are based on purely economic nonpolitical considerations and thus tries to keep them out of political discussions in Kenya's Parliament. Over the years, the practice in Kenya has been to prevent political debate about development projects, particularly those benefitting from aid, under the pretext of keeping politics out of development. In the absence of such debate, however, the development projects of post-independent Kenya have been a continuation of colonial or foreign activities, with support from foreign technical assistance surveyors, and in many cases, implemented and evaluated by the same foreign personnel. Under these circumstances, Kenya has lost its freedom to determine the course of national development independentiy.

The implications of external dependence are thus clear. To the extent that a nation is dependent upon foreign aid, foreign investment, and foreign trade for the creation of wealth and provision of goods and services, demands and decisions adopted in the developed economies become permanent inputs into the national policymaking process. Under such conditions, dependent nations such as Kenya have little prospect for self-sustained economic growth and expanded employment opportunities. The problems and demand of the national community must compete with and may be secondary to the requirements of external decisionmakers, which means that the Kenyan economy is becoming increasingly dependent on external factors (price increases for its two major exports of coffee and tea, and sources of international finance such as the IMF) to determine its capacity to accumulate surplus in the face of foreign 
exchange pressures.

\section{STATE ENTREPRENEURSHIP AS AN APPROACH TO} NATIONAL CONTROL OF THE ECONOMY

The government of Kenya has tried to expand its control of the national economy by increasing the level of state ownership of the means of production. The evidence presented below, however, leads to the conclusion that state participation in joint venture activities with foreign capital is primarily geared toward bringing about a broader base of local private control and ownership rather than toward public control of the means of production.

At independence, Kenya inherited an economy that was dominated in every respect by the expatriates and foreign concerns. Major financial institutions such as commercial banks and insurance companies were foreign owned and controlled. Agriculture, the backbone of the national economy, was also dominated by the settler farmers. Industrial enterprises were also controlled by the multinationals and expatriate concerns. Import-export trade as well as retail and distributive trade were also controlled in the same manner. It was obvious that something had to be done in the immediate post-independence period. Africanization of the economy was the political answer to the problem. The Africanization policy called upon the state to play an entrepreneurial role by taking equity participation with foreign capital (KG1). The principal agencies employed to promote industrial development are: the Industrial and Commercial Development Corporation (ICDC), the Development Finance Company of Kenya (DFCK), and the Industrial 
Development Bank (IDB). It is these three agencies that act as government instruments for engaging in joint ventures or partial nationalization. There are now some 115 public enterprises of various types in the country (GR95: 3 ) contributing more than $10 \%$ of the Gross Domestic Product in 1976 and employing about the same number of employees as the public sector (KG7, 1979).

At first these actions appeared to have been motivated by the desire to introduce public investment into strategic industries as a means of taking control of the economy. In reality, however, the state ownership (particularly the partnership solution) appears to have been more politically than economically motivated for two specific reasons. First, public participation is seen as necessary to ensure a rapid Africanization of equity ownership and managerial positions in an essentially foreign-dominated economic sector. In addition, Africanization was necessary to ensure the political stability necessary to attract more foreign investment and also to preserve the impression of expanding opportunities for all Kenyans. Viewed in this way, the policy is not one of Africanization, but one of Kenyanization. The means by which prominent Africans have access to multinationally-generated economic rewards cover a wide spectrum, from high salaries to joint venture partnerhsip. MNC executives believe Africanization is at the heart of this process (GR99: 163). Directorships are a second means by which prominent Africans share MNC sector rewards. In fact, most governmental ministers have ownership in MNC operations. The ICDC, itself the largest governmental investor in the MNC sector, is seen as the temporary custodian of its investment pending eventual 
transfer to direct or indirect African ownership.

Secondly, foreign equity participation in joint ventures is considered critical, particularly if the foreign investor brings in skills, know-how, patent rights, and other benefits required by Kenya. This latter view is emphasized in the Third Development Plan:

The inflow of capital is not generally the most important benefit to be achieved from such ventures. More valuable are technology, skills and techniques, which will enable Kenyans to staff and manage complex production processes, as well as experience and knowledge in the design and marketing of exports.

(KG4: 284)

These two points are consistent with the government's developmental goal of maximizing economic growth and Africanizing the economy. Nevertheless, the partnership solution seems to have reduced the capacity of the government to fulfill these developmental objectives. In practice, the policy seems to effer relatively little significant constraint on the activities of foreign economic actors. From the foreign investors' point of view, such participation institutionalizes special access to the policymaking body of the government, subject only to the increasingly important proviso that "these privileges be shared with African 'insiders'" (GR99:162). As a result, a significant symbiotic relationship has developed in Kenya between foreign capital and the state, focused around the structuring of "shared privileges," to the mutual advantage of the MNC sector and of the "insider" African bourgeoisie which dominates the Kenyan state (GR99: 162). In short, state entrepreneurship in Kenya has become an important mechanism to reinforce the private enterprise system rather 
than diminish its presence. A close examination of the activities of the Industrial and Commercial Development Corporation (ICDC) will illustrate this point clearly.

THE INDUSTRIAL AND COMMERCIAL DEVELOPMENT CORPORATION (ICDC) AND THE POLICY ENVIRONMENT

The ICDC was established in 1954 under the name of Industrial Development Corporation (IDC) to facilitate the industrial and economic development of the colony by the initiation, assistance, or expansion of industrial and commercial undertakings. At its initiation, the IDC took over the assets and liabilities of its predecessor, the East African Industrial Management Board (EAIMB), which had been established in 1944 to supply certain essential products during the war period (GR74: 3).

In order to define more accurately the corporation's present purpose and functions, the name was changed by the Industrial Development Amendment Act of 1967 to Industrial and Commercial Development Corporation (ICDC). Its purpose has been to promote and integrate Africans into the industrial and commercial structure of the country's economy. This trend is in total conformity with the policies laid down by the Kenyan government in Sessional Paper No. 10 of 1965 on African Socialism and Its Application to Planning in Kenya. The paper specified that the "ICDC will help African traders and industrialists to expand their operations in order to participate more fully in the development of the country" (KGI: 41). Clearly, the government intends to use ICDC as the official channel of industrial and commercial development of 
Kenya.

ICDC has invested in a wide range of industrial and commercial activities including the hotel, transport, assembly, bottling, catering, mining, processing, manufacturing, and engineering activities and such service industries as insurance, clearing, and forwarding. It is also an investor in other developmental finance institutions, notabiy the Industrial Development Bank and the Development Finance Company of Kenya (GR65).

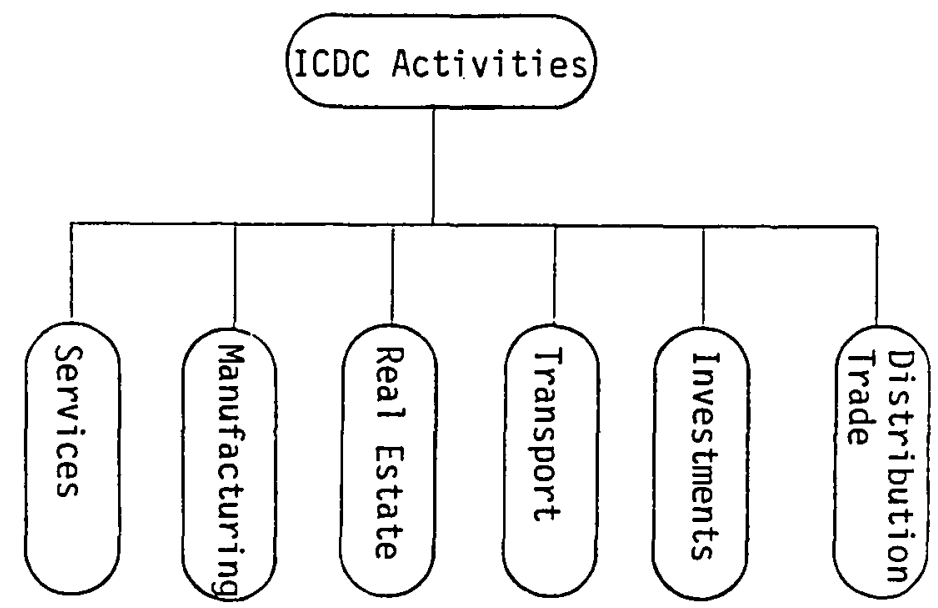

Figure 4. Structure of ICDC Organization.

Since the mid-1960's, the ICDC has been involved in new joint ventures with foreign capital, taking shares in the equity with a view to transferring the shares to Africans "whenever they have the necessary capital to acquire them" (GR74: 4). As of 1979, the ICDC has 12 subsidiary companies and has minority ownership in 47 other companies, most of them foreign multinationals (see Appendix $B$ ). Through its subsidiary 
companies, such as the Development Finance Company of Kenya (DFCK) and the Industrial Development Bank (IDB), the ICDC extends credit and provides monopoly advantages of African traders. In short, the ICDC, using the support of the state, has become an instrument for accelerating African private accumulation.

The government of Kenya has reaffirmed its commitment to a mixed economy in which private and public enterprises would exist side by side (KG4). This policy requires that public enterprises conform to standard capitalist performance criteria. Accordingly, the ICDC is intended to function as a profitmaking organization. Given the influence of foreign capital in the Kenyan economy, the policymaking functions of the ICDC are shared with many other interested parties, both governmental and nongovernmental.

A diagrammatic representation of the policy process is presented in Figure 5. The principal actors are the Ministry of Commerce and Industry (henceforth referred to as the Parent Ministry), the ICDC Board, the Legislature, the Office of the President (Inspectorate of Statutory Boards), and nongovernmental actors such as foreign banks, donor agencies, and joint venture partners (or multinational corporations). As a statutory body, the ICDC is responsible to the Minister of Commerce and Industry, which is represented on the Board of the ICDC through its Permanent Secretary (GR65). In theory, the Industrial Development Act of 1967 gives further powers and control over the activities of the ICDC to the Parent Ministry. In reality, however, the relationship of the two is formalistic. Although the Parent Ministry is given broad powers over the activities of the ICDC, such monitoring 


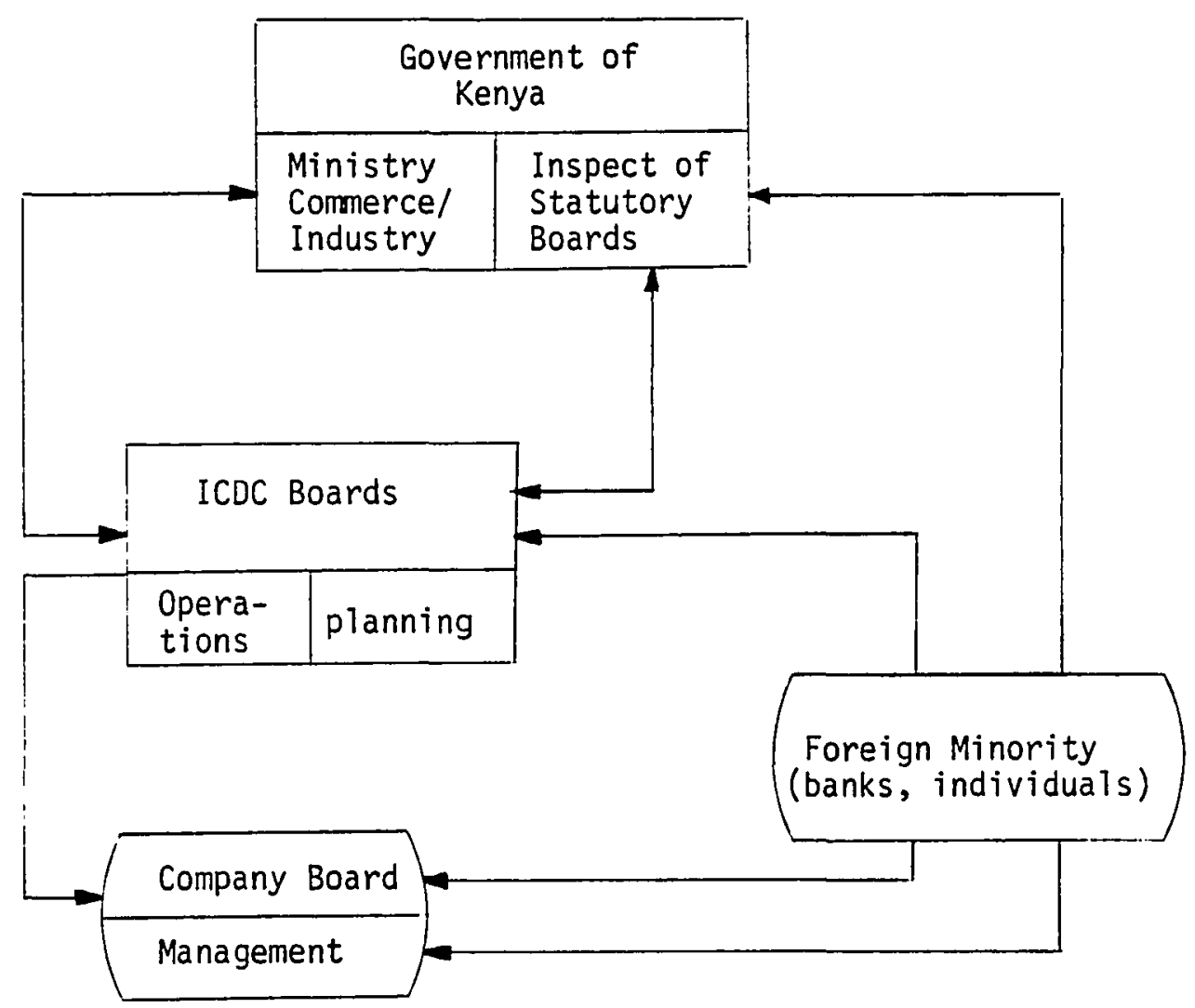

Figure 5. ICDC and the Policy Environment.

is never done. According to Oyugi, "the Parent Ministries tend to leave these organizations pretty much on their own" (GRI24: 10). First, government bureaucracies in Kenya (as is often the case in other developing countries as well) are weak, inefficient, and lack the expertise to implement and evaluate policies. Secondly, the functions and responsibilities of the parent ministry and the Inspectorate of Statutory Boards are never clearly specified. In the absence of strong governmental institutions, public enterprises are 
left to operate on their own. This situation leaves the policymaking process open to external economic actors.

The separation of economic decisionmaking from the political arena is one factor which allows external economic actors to dominate economic policy. The representative institutions, namely, the Parliament and the Kenya Africa National Union Party (KANU), are not strong enough to monitor the activities of public enterprises. Insofar as a national party system has existed in Kenyan politics, it is one of patron-client ties built around individuals who cross into each other's district or organizations. As long as the privileges are shared, the question of transformation is answered by never being formaliy posed. It is reasonable to conclude that some of the extra legal autonomy of Kenyan public corporations results from the fragmented nature of the government.

A major characteristic of the ICDC is its heavy dependence on foreign finances and management advice. As shown in Table XXXVI, the main source of finance for the ICDC was from the Kenyan government (47\%) in 1975 (GR65). External finance, which included a consortium of foreign commercial banks, accounted for $41 \%$ of the funds in 1975 . Loans from commerical banks and elsewhere have to be repaid later with interest and thus contribute significantly to the balance-of-payments difficulties. According to the Review of Statutory Boards (KG17: 22), public enterprises handle about half of the country's exports and require large amounts of foreign exchange for the importation of equipment and machinery.

The ICDC is directed by a board of ten directors, each of whom is appointed by the Parent Ministry. In theory, the Board is responsible 
TABLE XXXVI

ICDC, SOURCES OF FINANCE

Donor (1963)

Kenyan Government

United States

Other Sources

Total

Donor $(1974 / 75)$

Kenyan Government

KFW West Germany

Eximbatak of USA

DEG of West Germany

SIDA of Sweden

Commerical Banks

Other Sources

Profit and Reserves

Total shs. $9,320,000$

$1,000,000$

$3,500,000$

shs. $12,820,000$

shs. $63,960,000 \quad 47 \%$

$17,516,000 \quad 13 \%$

$6,866,000 \quad 5 \%$

$1,458,000 \quad 1 \%$

$7,004,000 \quad 5 \%$

$22,071,000 \quad 16 \%$

$3,000,000 \quad 3 \%$

$12,531,000 \quad 10 \%$

shs. $134,406,000$

Source: (GR65)

for all policy decisions within the framework of overall governmental policy and planning (GR65). In reality, however, the Board cannot be expected to play a leading role in policy matters, for several reasons. Given Kenya's patron-client political structure, patronage is deeply institutionalized in the recruitment system of public and private institutions (GRT6). Board members are appointed for political reasons rather than for their professional and managerial qualifications. The result has been that board members serve at the pleasure of the Minister and, 
therefore, cannot take independent positions on policy matters. In addition, there is a conflict of interest between public responsibilities and private profit. There exists a widespread practice of "straddling," whereby board members use their positions to secure business with the corporation on behalf of their own companies (GR32; GR41). This practice seems to have official sanction judging from a statement contained in the Ndegwa Commission Report which offered

no objection to the ownership of property or involvement in business by members of the public service to a point where their wealth is augmented perhaps substantially by such activities.

$(K G 14: 74)$

There are also other nongovernmental entities that influence the operations of public enterprises. The Federation of Kenyan Employers, which represents the bureaucracy of the large foreign companies; the Association of Kenya Manufacturers, which acts as a pressure group on behalf of manufacturing firms; and the Chamber of Commerce have easy access to the government on behalf of the multinational sector (GR99: 139).* The result is that policies governing the operations of the ICDC are usually compromises between the government and the private interests. What one often finds, therefore, is significant private influence in the running of public enterprises in Kenya.

At least 72 of the 81 subsidiaries interviewed by Langdon were members of the Kenya Association of Manufacturers, and at least 50 were members of the Kenya National Chamber of Commerce (GR99: 186). 
In light of the foregoing analyses, what role has the ICDC played in promoting national development? An answer to this question requires an evaluation of the ICDC's performance against its objective. Its objective is the creation of an African entropreneurial class allied to international capital. The question, is, then one of whether the ICDC is carrying out that calling to the fullest. According to Mwaniki, the "ICDC is more active as an agent of integrating state capital with foreign capital than of accumulating capital on behalf of nationals (GRI13: 35). In two separate studies of the ICDC's small industrial loan commitments, Mwaniki and Kaplinsky (GR79) concluded that the corporation's loan policy favors large industrialists, mostly foreign businessmen. The corporation frequently discontinues credit to African entrepreneurs so as to direct funds to the joint ventures with international big business. Thus, local savings are integrated with foreign capital, but as shown in the percentage of share holdings (Appendix $B$ ), control remains in the hands of foreign firms.

As the largest government investor in the manufacturing sector, the ICDC serves as a mechanism through which MNC-generated privileges are shared with affluent Africans. Government participation in economic activities through the ICDC is focused around the interests of the political class in control of the state. The issue of equitable and broadly beneficial development is not given the attention it deserves. But from the foreign investor's point of view, such participation lessens the capital commitment the investor must make. It institutionalizes special access for an enterprise to ease problems 
such as obtaining work permits, exemption from local borrowing restrictions, etc, because the government has a financial interest in the success of the firm.

Many foreign firms insist that the government participate as a regular business partner. Because they rely on such symbiosis, they generally have easy, informal access to decisionmaking. Of the 81 subsidiaries interviewed by Langdon (GR99), 55 firms, or $68 \%$, reported that they had informal contacts they could use to approach the government. As such, the ICDC facilitates the interaction between foreign capital and the Kenyan state. The overall impact of the ICDC in the Kenyan economy has, therefore, been to reinforce the growing inequalities of income among different social groups. From the perspective of national development, the state-centered, Western-oriented structure of the Kenyan economy inhibits severely the full productive use of much of the country's resources and thereby negates long-term, broadly based growth possibilities in the economy.

The conclusion to be drawn is that external economic actors play a crucial role in Kenya, act in a symbiotic relationship with the dominant African class, and are relatively unchecked by governmental regulations. Government investment through the ICDC does not exercise national control; conversely, it gives foreign companies greater access to economic privileges. 
SUMMARY

This chapter has tried to show that several domestic and external factors have inhibited the expansion of the Kenyan economy and that they have persisted, sometimes with growing intensity, since independence in 1963. The removal of these constraints would require not just marginal changes in policy and trade relations, but also profound structural adjustments, both internally and externally.

First, Kenya's growth performance since 1974 has been vulnerable to swings in its international terms of trade. The escalation of oil prices, the decline in the price of coffee and tea, and the increase in import bills imposed a serious deficit on current accounts and foreign exchange reserve. The continued outfiow of resources deprives Kenya of the needed foreign exchange inflow required for economic growth and expansion of productive employment to its population, particularly school leavers.

Secondly, public equity participation in different projects has also not been utilized as an instrument for the development of the pub1ic sector. Such participation is geared toward bringing about a broader base of local private control and ownership rather than toward public control of the means of production. This particular policy choice institutionalizes special access for an enterprise (foreign or domestic) into the national policymaking process to ease problems such as obtaining special import licenses, exemption from local borrowing restrictions, and the repatriation of profits. The combined effect of these economic problems is to reduce the ability of the 
Kenyan government to develop and implement policies directed toward the problem of urban unemployment. 
CHAPTER IV

GRADUATE UNEMPLOYMENT: A KENYAN DEVELOPMENT PROBLEM

Kenya has been identified in recent analyses as an example of a country with relatively successful economic growth and capital accumulation based on the dominance of foreign and domestic private capital (GR106; GR149). The Kenyan economy has experienced a fairly rapid rate of growth of real monetary GDP (we11 over 6\% per annum for 1964-70). Growth in manufacturing and commercial agriculture were more noticeable than growth in other sectors of the economy (see Table XIV). However, the detailed evidence of the national economic indicators from the 1970's reviewed in the previous chapter questions the potential of the Kenyan economy to sustain capital accumulation. A built-in structural constraint appears to choke off growth through the mechanism of large foreign exchange outflows.

The rapid growth of industry in Kenya based on multinational corporations has imposed many demands on the economy which it is incapable of meeting. An import-substitution policy has retarded the rapid growth of employment because of the capital-intensiveness of Kenyan industries. Since 1974, there has been a distinct slowdown in the growth of wage employment, particularly in the manufacturing sector where expanding production has not been matched significantly by expanding employment. Furthermore, Kenya's continued reliance on foreign technology and inputs has contributed to chronic trade and 
balance-of-payment deficits. To make up for these deficits, the government has borrowed large sums of money from the West. Unfortunately, debt servicing charges for these loans has added to the foreign exchange probiem. In the present context, all these forces have exerted an extremely powerful and complex influence and have set limits on the ability of Kenya to formulate and implement policies directed toward the problem of urban unemployment.

- THE SCHOOL LEAVER PROBLEM IN PERSPECTIVE

A major resultant problem facing Kenya is that for a great majority of those who finish school, no further educational or employment opportunities exist. In 1964, one year after Kenya attained political independence, it was found that of 103,000 Kenya Primary Education (KPE) examination candidates, approximately 67,000 (65\%) would not have access to secondary school or vocational training (GR8; GR23). The situation has worsened with each passing year. In 1980, about 350,000 pupils took the Certificates of Primary Education examinations (CPE's) throughout the country. Of these, 40,000 will fill form I vacancies in 2,000 government-maintained or aided schools. Fewer than 100,000 will receive similar placement in Harambee and private schools, leaving more than 200,000 pupils without any hope of further education (Nation, Dec 29, 1981:6). A more potentially damaging situation has been the trend toward unemployment among academic and technical secondary school graduates (GR57; GR83). At the postsecondary leve1, it has also been observed that increasing numbers of university graduates in arts, law, and some areas of commerce are experiencing difficulties 
in obtainina emplovment (PI 5, 7, 10).

Unemployment among school leavers at various levels of the educational system stems not so much from inappropriate education, as is often argued, as from the expansion of educational opportunities which are not accompanied by a corresponding expansion in the number of positions in employment (GR60, GR86). The particular reasons why school leavers are a problem, why they are frustrated, and why an increasing proportion of them are seeking work, is not so much that the opportunities do not exist, but that the opportunities open are not attractive in relation to those obtained by persons with comparable qualifications only a few years ago. In this sense, the school leavers seeking work are evidence, not of a shortage of jobs, but of a growing imbalance of opportunities in the modern sector (KG 69:67; $K G 5: 2.71)$.

The increasing imbalance between job seekers on the one hand and well paying jobs in the modern sector on the other has merely intensified the demand for education. This is understandable because education was the primary qualification for access to wage-earning jobs in the first few years after independence. This led to a tremendous quantitative expansion of enrollments in the face of an ultimate scramble for attractive jobs.

It was indicated in Chapter II that a balanced approach to secondary school expansion was subverted by the uncontrolled expansion of Harambee schools built by communities throughout the country. Inevitably, the richer communities were able to do more, and thus the availability of secondary school education became even more unequal 
than before independence. As a result, most of the pupils who attended rural and Harambee schools found themselves unable to compete on an equal basis with those pupils who attended government and urban high-cost schools. Since the type of jobs obtainable in the modern sector is related not only to the standard completed at school, but also how well the individual performed on examinations, we would expect rural pupils and those in Harambee schools, with low quality education, to be discriminated against the most. Figure 6 shows the relationship between the rate of expansion of positions in the public sector and private sectors and the rate of growth of educational enrollment for the period 1960-1979. An important point revealed in the figure is that annual growth of employment in both the private and public sectors was far lower than the annual growth rate of primary and secondary school enrollment. Considering that it is the students of these two levels of the educational system who have been competing for the positions which are available in the modern sector, then it is obvious that there will necessarily be a surplus of school leavers in comparison with the number of available jobs. Since the long range trend has been one of modern sector jobs increasing at a slower annual rate than the output of the educational system, then educated unemployment becomes a serious potentially long term problem in Kenya (PI 10, 11, 14).

The magnitude of the school leaver problem is better understood after an examination of the number of job openings each year in the modern sector. It is estimated that Kenya's labor force as of 1980 is slightly greater than 7 million, of which about 1.2 million are engaged 


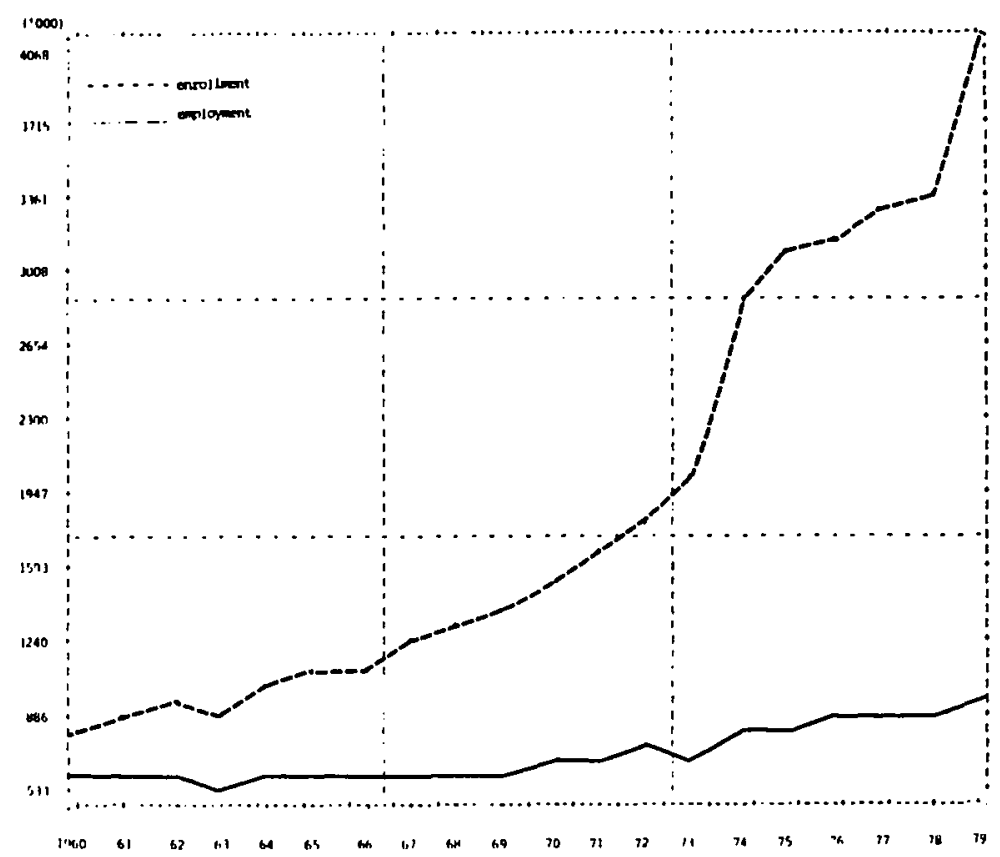

Figure 6. Expansion of Employment and Enrollments.

in the MES or wage employment (KG6, 1980). And according to the fourth Development Plan (KG5: 481), it is expected that the population oi working age will increase over the plan period by 266,000 per annum. Of this number, approximately 50,000 can expect to find work in the recorded modern sector (KG5: 48). Competing for those few jobs are 100,000+ primary school leavers, 50,000 junior secondary school leavers, and at least 2,000 graduates from universities, polytechnical schools and institutes of technology (GR70: 9). Tables XXXVII and XXXVIII should facilitate an understanding of the problem generated by illusionary aspirations of school leavers. 
TABLE XXXVII

ENROLLMENT STATISTICS BY EDUCATIONAL

LEVEL AND YEAR

\section{Educational \\ Level}

Standard 7

Form I

Form IV

Form $V$

Form VI

University undergraduate intake (combined)

\begin{tabular}{|c|c|c|c|c|}
\hline 1976 & 1977 & 1978 & 1979 & $1980^{\star \star *}$ \\
\hline 243,214 & 235,925 & 258,610 & 281,689 & 351,860 \\
\hline 94,834 & 106,496 & 104,733 & 104,733 & 112,185 \\
\hline 48,045 & 53,800 & 61,680 & 74,788 & 87,513 \\
\hline 5,208 & 5,240 & 7,039 & 8,568 & 10,317 \\
\hline 4,610 & 5,251 & 5,581 & 7,632 & 9,316 \\
\hline 1,398 & 1,477 & $1,684^{\star \star}$ & 2,371 & 2,471 \\
\hline
\end{tabular}

* Indicated educational level is deemed to be terminal as characterized by a centralized selective examination at the end of the year.

** Intake figure estimate

$\star \star \star$ Provisional

$\star \star \star \star$ Nairobi Univ and Kenyatta Univ College. Excludes foreign students.

Sources: (KG6, 1981: 201; KG 12)

TABLE XXXVIII

SCHOOL LEAVER RESIDUALS BY EDUCATIONAL LEVEL, 1977-80

\begin{tabular}{|c|c|c|c|c|c|c|}
\hline \multirow{2}{*}{$\begin{array}{c}\text { Educational } \\
\text { Level } \\
\end{array}$} & \multirow[b]{2}{*}{1977} & \multirow[b]{2}{*}{1978} & \multirow[b]{2}{*}{1979} & \multirow[b]{2}{*}{1980} & \multicolumn{2}{|c|}{$\begin{array}{l}\text { Average Annual Growth } \\
\text { Rate, 1977-80 } \\
\end{array}$} \\
\hline & & & & & $\#$ & $\%$ \\
\hline Standard 7 & 136,718 & 132,192 & 153,877 & 169,504 & 10,929 & 7.4 \\
\hline Form IV & 42,805 & 46,761 & 53,112 & 64,441 & 7,212 & 13.9 \\
\hline Form VI & 3,133 & 3,567 & 3,272 & 5,221 & 696 & 18.3 \\
\hline Total & 188,656 & 182,520 & 210,261 & 239,166 & 18,837 & 8.2 \\
\hline
\end{tabular}


Tables XXXVII and XXXVIII reveal that a large proportion of residuals from one educational level to the next have to compete for wage employment because the educational system cannot absorb them for further advancement. Obviously, this is indicative of the intensification of the paper qualification syndrome (PQS) because of the widely held belief that a high educational attainment automatically leads to high wage employment in the modern sector (GR157). In the 1960's, practically every student who received an ordinary level school certificate was easily absorbed into the modern sector, notwithstanding examination performance, because of the changing political and economic circumstances following independence. Educational attainment was then directly related to high economic returns from formal wage employment, a factor that necessitated acceleration of the paper qualification syndrome. Continuation of this trend has increased school output, causing the labor market to become glutted.

For Kenya, a relatively poor country, to spend $30 \%$ of its national budget on education and then be faced with a high rate of unemployment among the educated can be seen as a tremendous drain of national resources. This is a point of major concern among academic and official circles and has been referred to time and again in previous research and official reports (GR39; GR68: 171; GR70; GR71; GR 83; GR129).

In the context of national planning, three significant problems emerge. First, unemployment of school leavers is perpetuating the shortages of skills in a wide range of occupations (see Table XXXIX). This first problem might be called the manpower problem. 
TABLE XXXIX

PUBLIC SECTOR MANPOWER PROJECTIONS, 1979-83

\begin{tabular}{|c|c|c|c|c|}
\hline $\begin{array}{l}\text { Employment } \\
\text { Field }\end{array}$ & $\begin{array}{l}\text { Current1y } \\
\text { Employed } \\
1978-79 \\
\end{array}$ & $\begin{array}{c}\text { Additional } \\
\text { Requirements } \\
1979-83 \\
\end{array}$ & $\begin{array}{c}\text { Additional } \\
\text { Supply } \\
1979-83 \\
\end{array}$ & $\begin{array}{c}\text { Surplus }(+) \\
\text { or } \\
\text { Deficit }(-) \\
1979-83 \\
\end{array}$ \\
\hline $\begin{array}{l}\text { Medical doctors } \\
\text { Dentists } \\
\text { Pharmacists } \\
\text { Clinical Officers } \\
\text { Registered Nurses } \\
\text { Enrolled Nurses } \\
\text { Public Health Offcrs }\end{array}$ & $\begin{array}{r}542 \\
22 \\
30 \\
1,002 \\
1,223 \\
4,009 \\
250\end{array}$ & $\begin{array}{r}724 \\
138 \\
148 \\
835 \\
1,037 \\
3,891 \\
140\end{array}$ & $\begin{array}{r}428 \\
110 \\
92 \\
552 \\
690 \\
2,236 \\
107\end{array}$ & $\begin{array}{lr}- & 296 \\
- & 28 \\
- & 56 \\
- & 283 \\
- & 347 \\
- & 1,655 \\
- & 33\end{array}$ \\
\hline $\begin{array}{l}\text { Public Health Techs } \\
\text { Pharmaceutical Techs } \\
\text { Lab Technologists } \\
\text { Lab Techs } \\
\text { Radiographers } \\
\text { Physiotherapists } \\
\text { Occupational Thrpsts }\end{array}$ & $\begin{array}{r}642 \\
221 \\
180 \\
284 \\
217 \\
116 \\
45\end{array}$ & $\begin{array}{r}2,099 \\
669 \\
540 \\
1,400 \\
933 \\
544 \\
555\end{array}$ & $\begin{array}{r}497 \\
138 \\
77 \\
264 \\
122 \\
101 \\
68\end{array}$ & $\begin{array}{lr}- & 1,602 \\
- & 531 \\
- & 463 \\
- & 1,136 \\
- & 811 \\
- & 443 \\
- & 487\end{array}$ \\
\hline $\begin{array}{l}\text { Dental Technologists } \\
\text { Orthopedic Technolgsts } \\
\text { Family Health Field Eds } \\
\text { Nutrition Field Wrkrs } \\
\text { Jurists } \\
\text { Engineers } \\
\text { Agronomists/Vets (grads }\end{array}$ & $\begin{array}{lr} & 15 \\
\text { ts } & 12 \\
\text { ds } & 430 \\
210 \\
217 \\
\\
427 \\
\text { ds ) } 841\end{array}$ & $\begin{array}{r}115 \\
138 \\
930 \\
280 \\
527 \\
999 \\
1,478\end{array}$ & $\begin{array}{r}13 \\
35 \\
1,012 \\
248 \\
250 \\
325 \\
900\end{array}$ & $\begin{array}{r}102 \\
103 \\
82 \\
32 \\
277 \\
674 \\
578\end{array}$ \\
\hline $\begin{array}{l}\text { Physical Scientists } \\
\text { Grad Level Teachers } \\
\text { Agronmsts/Vets (semi- } \\
\text { prof) }\end{array}$ & $\begin{array}{r}107 \\
2,864 \\
1,399\end{array}$ & $\begin{array}{r}297 \\
3,829 \\
1,684\end{array}$ & $\begin{array}{r}300 \\
3,700 \\
1,500\end{array}$ & $\begin{array}{lr}+ & 3 \\
- & 129 \\
- & 184\end{array}$ \\
\hline $\begin{array}{l}\text { Other qualified Agron- } \\
\text { omists/Vets }\end{array}$ & $-4,399$ & 8,404 & 2,250 & $-\quad 6,154$ \\
\hline $\begin{array}{l}\text { Engineering Techs } \\
\text { Printing Techs } \\
\text { Scientific Techs } \\
\text { Other techs/artisians }\end{array}$ & $\begin{array}{r}1,760 \\
183 \\
429 \\
523\end{array}$ & $\begin{array}{r}3,365 \\
325 \\
677 \\
1,225\end{array}$ & $\begin{array}{r}3,600 \\
200 \\
540 \\
900\end{array}$ & $\begin{array}{ll}+ & 235 \\
- & 125 \\
- & 137 \\
- & 325\end{array}$ \\
\hline
\end{tabular}

Source: (KG5) 
The structure of the educational system, with its colonial mold, is considered the main source of the problem. Secondly, when education ceases completely after only seven years, what was painfully learned will shortly be forgotten. Furthermore, this short time in school often raises false expectations of future employability. Thirdly, the educated unemployed represent an articulate and politically conscious group (relative to the general population of the country), with the ability to mobilize public opinion and governmental opposition. Recent political events in Kenya tend to confirm this view. Since the attempted coup of August 1, 1982 (which was largely supported by students), the government of Kenya closed the University and other colleges. This and other studies (GR59) suggest that the prospects of unemployment among the educated could become a major impetus for student unrest. Therefore, the deep rooted, socioeconomic causes of these educational problems should be understood in their proper societal context if realistic and viable solutions are to be suggested.

\section{THE STRUCTURE OF KENYAN EDUCATION}

At independence, Kenya inherited an educational system carefully designed for the exclusive benefit of European settlers in the country. The examination and selection process, the content of educational curricula, the structuring of educational administration and finance still reflect the pattern of social relations which existed during the colonial period. Such continuity in educational policy contributes immensely to the perpetuation of neocolonialism and tends to discriminate against the vast majority of Kenyans who, by virtue of their 
low social status, cannot afford to receive the type of quality education required to gain access to modern sector employment.

The Republic of Kenya is divided into seven provinces plus the Nairobi extraprovincial district. The seven provinces are subdivided into a total of 38 districts. There is no provincial government as such. Rather, the provinces serve as administrative boundaries for various central governmental activities (GRT23). For example, the system of primary education is overseen by the seven Provincial Education Officers, who in turn delgate responsibility to the District Education Officers. Superimposed upon the system of provinces and districts is a network of local governmental bodies whose jurisdictions often, but not always, coincide with district boundaries. The local governmental bodies in several designated urban areas are called municipal councils, and the rest of the country is subdivided into county councils.

\section{Primary Education}

Soon after Kenya achieved independence in 1963, the administration and operation of primary schools became the responsibility of the municipal and county councils. The central government, through the Ministry of Education, became responsible for curriculum, examinations, and the setting of standards. The eight year primary cycle established by the Beecher Commission of 1949 was later shortened to seven years. Secondary education extended for six years and was divided into a lower course of four years duration (called Forms) and an upper course of two years duration. This structure is shown graphically in Figure 7. 


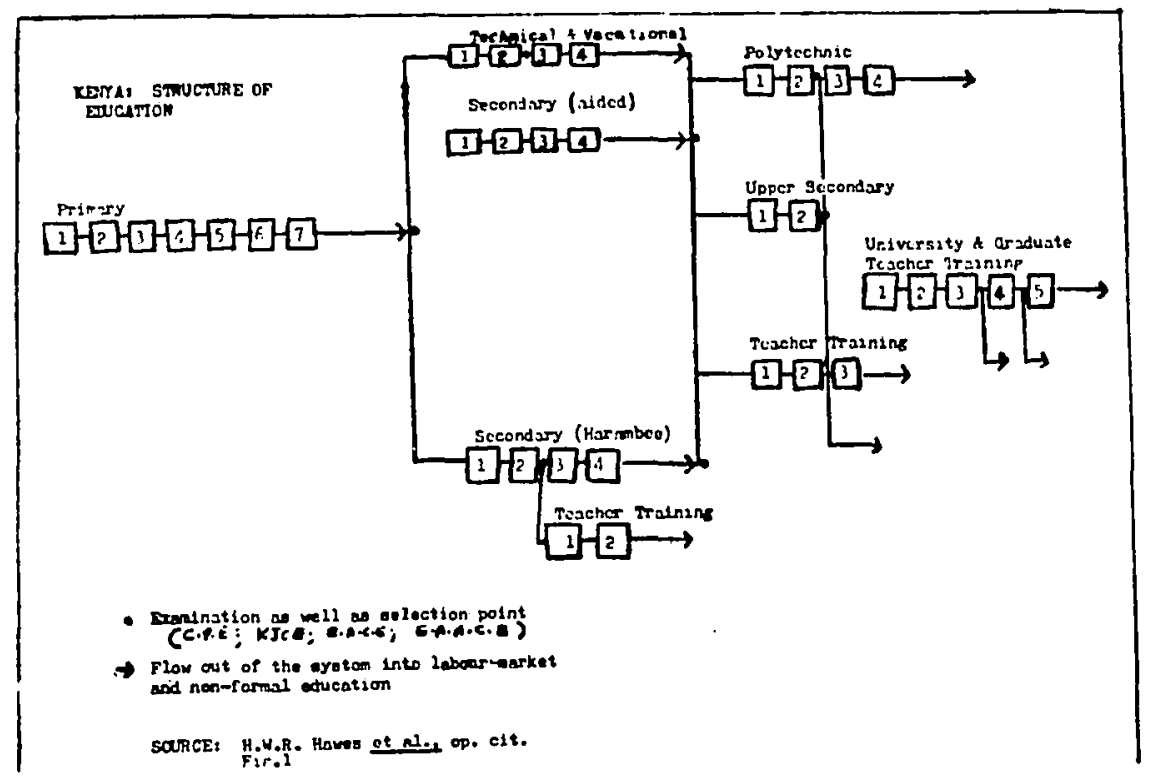

Figure 7. Structure of Education.

Source: (GR62)

Prior to 1970, rural primary schools were funded partly by school fees, partly by local government revenues, and partiy by central government revenues. The most important sources of funds were grants from the central government, which provided roughly $35 \%$, followed by graduated personal tax funds (23\%), and school fees (24\%) in 1969 (GR48). However, in 1971, because of the financial difficulties of the districts, the central government took over from the councils the responsibility for financing education and other services. The central government now collects school fees and graduated personal taxes, and no longer extends grants to the councils. This decision did not, however, affect primary schools within the jurisdiction of the municipal councils, of which there are seven in the country. 
Primary schools in the rural areas are run by District Education Boards, which are composed of governmental officials, educators, and private citizens. The DEB's employ teachers directly through the Teachers' Service Commission (an ad hoc subsidiary of the Ministry of Education) and collect schoor fees in addition to performing their administrative and curricular functions. For budgetary purposes, the Ministry of Education grants funds to the DEB's, which pay the salaries of the teachers.

\section{Secondary Education}

The secondary schools are classified as either "aided" or "unaided." The aided (or government maintained) schools are completely under the supervision of the Ministry of Education, and all budgetary and educational responsibilities belong to the government. There are also some assisted schools within the aided school system, where the central government pays $80 \%$ of the salaries of both the teaching and nonteaching staffs.

The unaided schools, on the other hand, operate outside the established jurisdictions of the government. The Ministry of Education has little to do with the unaided school system other than to certify its existence. These schools include private schools which are owned and operated by enterprising individuals and the Harambee or self-help schools built with community contributions. In 1969 , the central government initiated a small scale program to assist selected Harambee schools in securing teachers. The government also takes over a number of Harambee schools each year, thus relieving the local 
communities from financial responsibility.

\section{Examination and Selection Process}

Accompanying the ferocious competition for access to educational opportunity in Kenya is an emphasis on academic criteria for advancement within the system. There has been little attempt to break away from the inherited colonial pattern of academic credentials. In fact, a tightening of these requirements has occurred as employment opportunities have become scarce; the minimum educational requirements have been raised, and research and reform efforts have been directed toward improving the efficiency of the examinations, thus perpetuating the neocolonial situation (GR38; GR143).

At the end of the primary cycle, nearly all students sit for the Certificate of Primary Education Examination (CPE). Those who pass the examination go on to secondary schools. Those who do poorly frequently repeat Standard VII in order to improve their performance the following year. Passing the EACE qualifies students for admission to senior secondary or technical schools. Passing the EAACE qualifies students for admission to the university. The pyramidical structure of the Kenyan educational system is perhaps best exemplified by Figure 8 , which diagrams school enrollment for the period 19731974.

As Figure 8 shows, the critical problem in Kenyan education is the scarcity of secondary schools. Of the 227,000 students who sat for the CPE examination in 1974, only 58,638 (25\%) were admitted to secondary schools. Of these, 32,885 (56\%) were admitted into the 




Figure 8. Expansion of Employment and Enrollments.

Source: (GR62: 7)

unaided secondary school system. The remaining 168,362 (75\%) left school without any prospect for further schooling or employment. On 
the basis of previous research by Fordham and Sheffield (GR51), approximately $33 \%$ of the 1974 primary school leavers were expected to find work in the formal or informal sectors of the economy. Dore et al (GR44) gave a much higher estimate of unemployment. Of the estimated 347,000 children entering the labor market in 1980 , $57 \%$ had completed primary school and $21 \%$ had completed at least four years of secondary school. Making the very optimistic assumption that there was a $5 \%$ growth in modern sector jobs and that $2 \%$ of the existing modern sector job holders died or retired, the net increase in modern sector jobs could be enough to accomodate only $13 \%$ of the primary school age students and $6 \%$ of the secondary school age students. Primary school leavers unable to find modern sector jobs would comprise $44 \%$ of the total. The corresponding figure for unemployed secondary school leavers would be $15 \%$. The unemployment figure for females was much higher than for males at both the primary and the secondary level. Thus, a major bottleneck occurs every year at both the primary and the secondary level, and this bottleneck has intensified the competition for nonexistant jobs.

The Primary School Leavers. Because of the relatively limited number of places in secondary schools, the chief problem with Kenya's educational system starts at the primary level. As Table XXXX indicates, on the average, about $30 \%$ of the primary school candidates pass the Certificate of Primary Education (CPE) examination and continue their education in government and private secondary schools. The average opportunity index for admission to the government aided secondary 
TABLE $X X X X$

SUMMARY OF PRIMARY SCHOOL CANDIDATES AND RESIDUALS 1964-81

Form I Opportunities

\begin{tabular}{|c|c|c|c|c|c|}
\hline Year & $\begin{array}{c}\text { KPE/CPE } \\
\text { Candidates } \\
\end{array}$ & $\begin{array}{c}\text { Aided } \\
\text { Schools } \\
\end{array}$ & $\begin{array}{l}\text { Unaided } \\
\text { Schools }\end{array}$ & $\begin{array}{c}\text { Total } \\
\text { Secondary } \\
\end{array}$ & Residuals \\
\hline 1964 & 103,400 & 11,500 & 24,900 & 36,400 & 67,000 \\
\hline 1965 & 148,900 & 12,800 & 11,300 & 24,100 & 124,800 \\
\hline 1966 & 146,900 & 14,500 & 17,700 & 32,200 & 114,700 \\
\hline 1967 & 149,700 & 15,700 & 20,500 & 36,200 & 113,500 \\
\hline 1968 & 159,700 & 18,900 & 21,900 & 40,800 & 178,900 \\
\hline 1969 & 159,900 & 21,200 & 20,800 & 42,000 & 117,900 \\
\hline 1970 & 166,900 & 22,500 & 24,900 & 47,400 & 119,500 \\
\hline 1971 & 176,100 & 24,300 & 30,000 & 54,300 & 121,800 \\
\hline 1972 & 187,600 & 26,700 & 32,800 & 59,500 & 128,100 \\
\hline 1973 & 200,300 & 27,300 & 37,400 & 64,700 & 135,600 \\
\hline 1974 & 216,200 & 27,600 & 46,100 & 73,700 & 142,500 \\
\hline 1975 & 226,700 & 27,800 & 42,200 & 70,000 & 156,700 \\
\hline 1976 & 243,214 & 27,715 & 78,781 & 106,496 & 136,718 \\
\hline 1977 & 236,925 & 30,587 & 74,746 & 104,733 & 132,192 \\
\hline 1978 & 258,610 & 29,180 & 75,553 & 104,733 & 153,877 \\
\hline 1979 & 287,689 & 37,272 & 74,913 & 112,185 & 169,504 \\
\hline 1980 & 351,860 & 40,000 & 111,860 & 151,860 & 200,000 \\
\hline Total & $3,414,598$ & 415,554 & 745,753 & $1,161,307$ & $2,253,291$ \\
\hline
\end{tabular}

Opportunity Index for Form I Admission

$12 \% \quad 22 \% \quad 34 \%$

Residuals as \% of Candidates

$66 \%$

Sources: (KG6, 1964-81; KG7, 1964-81;

KG8, 1964-78) 
school system was only $12 \%$, while the overal1 opportunity index for both government and Harambee schools was $34 \%$. On the whole, the aided school system accounted for $39 \%$ of secondarv school candidates, while the Harambee schools accounted for over $60 \%$ of all secondary enrollments. Had it not been for the Harambee schools. the educational svstem of Kenva would have collapsed. The Harambee schools thus serve as cushions.

Despite the limited number of students who are admitted to secondary schools every year, the available form I places are not eveniy distributed, as demonstrated in Table XXXXI. In the 1975 CPE,

TABLE XXXXI

OPPORTUNITIES FOR CPE CANDIDATES, 1975

BY TYPE OF SCHOOL AND PROVINCE

1975 Proportion Gaining Form 1 Places

\begin{tabular}{|c|c|c|c|c|c|}
\hline Province & Candidates & Aid & & Unai & ded \\
\hline Central & 50,361 & 6,550 & $(13 \%)$ & 11,072 & $(22 \%)$ \\
\hline Coast & 12,479 & 2,084 & $(16 \%)$ & 2,533 & $(20 \%)$ \\
\hline Eastern & 42,059 & 4,379 & $(10 \%)$ & 9,153 & $(22 \%)$ \\
\hline N Eastern & 547 & 151 & $(28 \%)$ & - & - \\
\hline Nyanza & 43,412 & 4,109 & $(9 \%)$ & 6,660 & $(15 \%)$ \\
\hline R Valley & 31,782 & 4,162 & $(13 \%)$ & 5,623 & $(18 \%)$ \\
\hline Western & 30,422 & 3,835 & $(13 \%)$ & 7,274 & $(24 \%)$ \\
\hline Nairobi & 8,488 & 3,392 & $(40 \%)$ & 2,722 & $(32 \%)$ \\
\hline Kenya & 219,550 & 28,663 & $(13 \%)$ & 45,037 & $(21 \%)$ \\
\hline
\end{tabular}

of 220,000 candidates, about $28,663(12 \%)$ were admitted into government-aided secondary schools, while another 45,000 (21\%) were admitted to Harambee secondary schools. The corresponding figures for 
Nairobi show that $40 \%$ of the candidates were admitted to government schools and another $35 \%$ to Harambee schools. Thus, the probability of gaining Form I places from a Nairobi primary school is significantly greater than from a rural primary school. In the case of Harambee schools in Nairobi, access is determined almost entirely by the student's ability to meet the fees which are charged.

The pyramidical structure of the Kenyan educational system may be better understood from the following diagram which illustrates projected school enroliment for the period 1980-1993 (K'G16, 1981).

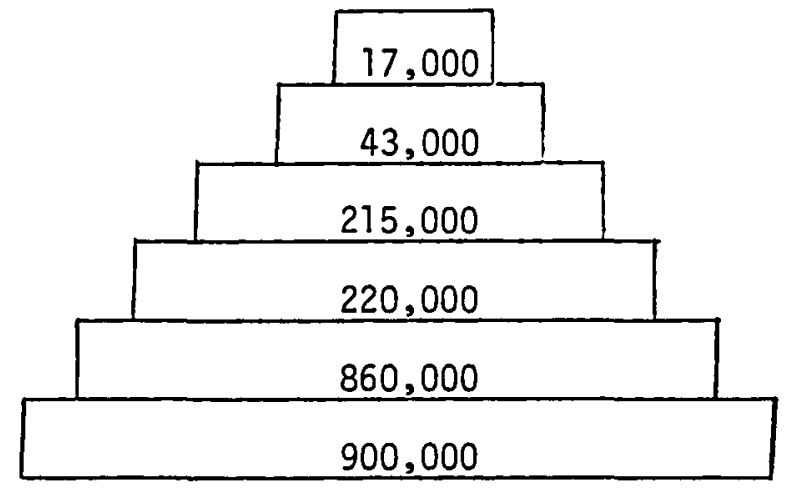
University 1992 1990 1987 1986 1980 900,000 Form VI Form VI Form I Standard 7 Standard I

Fiqure 9. Projected School Enrollment 1980-1993.

Data were taken from a recent government report on university education in Kenya (March, 1981). The report stated that in 1980, some 900,000 children enrolled in Standard 1; about 860,000 of them will be expected to sit for CPE in 1986. If the present trend continues, about 220,000 of them will be able to proceed to Form I in 1987 (double the present intake), with about 215,000 being allowed to sit for EACE in 1990. Thereafter, about 43,000 will likely aspire to proceed to senior secondary ( $A$ level) and the university, although only about 17,000 of 
them are apt to meet the minimum entrance requirements for university admission (KGI6: 71). Even if the government opens up a second university (as projected), it is unlikely that the projected 17,000 candidates will be absorbed into the university system.

Given the statistical realities of secondary school opportunities, primary school for the majority of pupils is terminal formal education. Unfortunately, the primary school content and teaching methods, dominated by the CPE examination--a computerized multiple choice test made up of three papers (English, mathematics, and general knowledge)--are almost inseparably tied to the task of preparation for secondary education rather than a test of skill acquisition (GR143). Furthermore, the performance of repeaters and older children is categorically better than that of first sitters and younger students. It has been convincingly argued that to a large extent, the CPE tests the teachers rather than the pupits. Because of the orientation of the primary school curriculum towards the CPE, other important issues, such as the quality of education, have been neglected.

The validity of the CPE examination as an instrument for selecting children for secondary school must be viewed within the context of the regional distribution of educational resources (i.e., the number of qualified teachers, etc) and opportunities discussed in the previous chapter. Results of student performance in national examinations tend to ignore historical and other economic and political factors which influence the nature and structure of the school system (GR85; GRI18; GR143). Those students who come from the relatively 
rich areas, such as Central Province or the urban centers of Nairobi, perform better than those students from the relatively deprived areas of the Northern, Eastern, or Coast Provinces. The unequal distribution of qualified teachers and other school inputs tend to intensify regional inequalities among the fortunate and the less fortunate provinces.

A number of questions have been raised regarding the validity of the CPE as an objective criteria for selection of secondary school bound students. The Report of the National Committee on Educational Objectives (KG15: 131) highlights the major problems with the CPE:

- The examination has been dominated by items which test abilities related only to the cognitive aspects of learning. As a result, it has encouraged memorization of facts rather than acquisition of career oriented skills.

- The examination has not fulfilled the function of a terminal examination for the majority of primary school leavers who have no chance of going further with education. In particular, it has given only limited attention to agriculture and practical subjects and has therefore not prepared children for life in the rural environment where the majority of them will live.

- The examination favors children from urban schools because there settings provide an improved socio-economic background and surroundings, more qualified teachers, and excellent school facilities.

The reasons for this situation are understandable. Since independence, competition for secondary school entry has steadily intensified. The simplest way of making the examination more difficult 
(thereby keeping the numbers of graduates low) is to increase the proportion of items requiring specialized knowledge. Moreover, most of the people responsible for the certificate have been recruited from secondary teaching and are naturally concerned about ensuring a continued supply of high-caliber recruits to the secondary schools. They have been supported by the manpower planners, who until quite recently, were preoccupied with the need to provide for Kenya's highlevel manpower needs, particularly in the occupations still dominated by expatriates (GR69: 236). The result has been that the syllabus of upper primary schools, and particularly the Certificate of Primary Education (CPE), has become overloaded with topics that are the more proper concern of the secondary schools. The CPE does not make a more accurate prediction of which pupils would make the best use of secondary-level education.

Some attempts have been made to reform the primary school curriculum by adopting a freer approach to teaching in which children are encouraged to be more spontaneous and to draw on their environment and by adding a rural aspect to the science courses. But these efforts to change the curriculum are largely nullified by the examination system. The questions related to agriculture in the examination for the CPE in 1971 accounted for 17 marks out of a possible 250 (50 for mathematics, 100 for English, 100 for history, geography, science, and nature study) (GR69: 237; GR70: 65). Clearly, the weight given to a subject in the examination and the form the questions take define the method and content of teaching. This is known as the "backwash effect" of the examination structure. 
The Secondary School Leavers. Although initial expansion of the secondary school system was justified by the manpower needs of the country, it was the problem of primary school leavers which later became the driving force for such expansion. International aid and community self-help encouraged the expansion of secondary schools; the Harambee schools now outnumber the government schools. By the time these Harambee schools had been funded, built, and the first batch of students graduated in 1968, the halcyon era of the secondary school was over. Only those with some sort of distinction in the EACE examination could any longer secure the sort of jobs that had spurred the vast building programs (GR83; GR88).

If school certificate results may be taken as a measure of the quality of education in aided and unaided schools, then it may be said that the quality of the unaided schools is extremely poor. According to the examination results presented in Table XXXXII, on the next page, the Harambee schools are producing failures. The table shows that $48 \%$ of the pupils in government schools obtained Division I-III certificates between 1972 and 1979. During the same period, the proportion of Harambee school students who merited Division I-III passes was only $16 \%$. The combined percentage of those who received EACE certificates (Division IV) and those who failed was $91 \%$ in the Harambee schools and $53 \%$ in government schools. Fewer than 6,000 students were admitted annually into senior secondary or A Tevel schools and the Mombasa and Kenya Polytechnics. In 1979, approximately 53,000 secondary school graduates were out looking for work. This figure is well in excess of the 50,000 jobs the economy 
TABLE XXXXII

EACE EXAMINATION, PERFORMANCE OF CANDIDATES

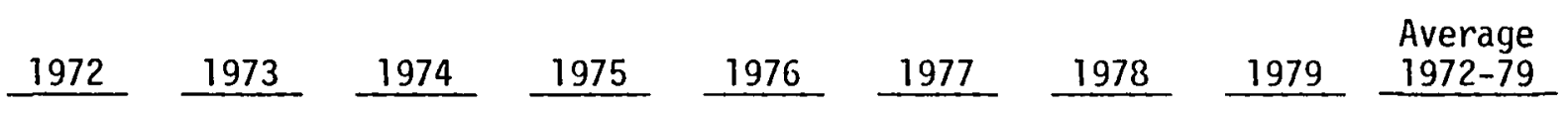

Aided Schools

$\begin{array}{lrrrrrrrrr}\text { Candidates } & 26,217 & 28,385 & 32,311 & 38,228 & 47,239 & 55,878 & 60,707 & 70,000 \\ \text { Div 1-3 } & 12,494 & 14,199 & 15,847 & 18,821 & 22,410 & 28,250 & 29,889 & 27,302 & \\ \% & (48 \%) & (50 \%) & (49 \%) & (49 \%) & (47 \%) & (51 \%) & (49 \%) & (39 \%) & 48 \% \\ \text { Div } 4 & 8,138 & 8,598 & 8,866 & 10,532 & 7,660 & 15,410 & 16,648 & 23,712 & \\ \% & (31 \%) & (30 \%) & (27 \%) & (28 \%) & (16 \%) & (27 \%) & (27 \%) & (34 \%) & 28 \% \\ \text { Fail } & 5,585 & 5,588 & 7,593 & 8,875 & 17,169 & 12,488 & 14,170 & 18,936 & \\ \% & (21 \%) & (20 \%) & (24 \%) & (23 \%) & (36 \%) & (22 \%) & (23 \%) & (27 \%) & 25 \%\end{array}$

Unaided Schools

$\begin{array}{lcccccccccc}\text { Candidates } & 5,109 & 6,044 & 5,773 & 9,698 & 5,004 & 5,330 & 4,214 & 4,158 & \\ \text { Div 1-3 } & - & - & - & 1,235 & 846 & 944 & 786 & 436 & \\ \quad \% & - & - & - & (13 \%) & (17 \%) & (18 \%) & (19 \%) & (11 \%) & 16 \% & \\ \text { Div 4 (EACE) } & 3,832 & 4,545 & 3,522 & 4,960 & 1,553 & 2,492 & 2,067 & 1,988 & & \\ \% & (75 \%) & (75 \%) & (61 \%) & (51 \%) & (31 \%) & (47 \%) & (49 \%) & (48 \%) & 55 \% & \\ \text { Fai1 } & 1,277 & 1,499 & 2,251 & 3,503 & 2,605 & 1,894 & 1,361 & 1,734 & & \\ \quad \% & (25 \%) & (25 \%) & (39 \%) & (36 \%) & (52 \%) & (35 \%) & (32 \%) & (41 \%) & 36 \% & \vec{\infty}\end{array}$

Source: (KG7, 1980: 200) 
generates annually.

The next examination hurdle for those admitted to A level schools (approximately 6,000) comes at the end of Form VI. The EAACE examination is strictly used to select candidates to the university. Even at this lever, the ability of the university to absorb qualified students is limited, as shown in Table XXXXIII below.

\section{TABLE XXXXIII}

FORM VI LEAVERS AND CANDIDATES ADMITTED INTO THE UNIVERSITY OF NAIROBI AND KENYATTA UNIVERSITY COLLEGE, 1970-1980

\begin{tabular}{lccc} 
Year & $\begin{array}{c}\text { Form VI } \\
\text { Leavers* }\end{array}$ & $\begin{array}{c}\text { \# Adm to the U of Nairobi } \\
\text { \& Kenyatta Univ Coliege }\end{array}$ & $\begin{array}{c}\# \\
\text { Left Over }\end{array}$ \\
\cline { 2 - 3 } 1970 & 2,672 & 1,279 & 1,393 \\
1971 & 3,448 & 1,215 & 2,233 \\
1972 & 3,953 & 1,641 & 2,312 \\
1973 & 5,602 & 1,735 & 3,867 \\
1974 & 6,459 & 1,469 & 4,990 \\
1975 & 7,998 & 1,519 & 6,479 \\
1976 & 7,493 & 1,804 & 5,689 \\
1977 & 8,655 & 2,461 & 6,194 \\
1978 & 8,429 & 2,592 & 5,837 \\
1979 & 11,032 & 2,611 & 8,421 \\
1980 & 12,306 & $2,600^{* *}$ & $11,706^{\star *}$
\end{tabular}

* Includes private candidates

** University admission for the 1981/82 academic year was given from the Nation Newspaper, February 14, 1982, p 3.

Source: (KG8)

For example, the total number of applications received for the 1981/82 academic year was 9,298. Of these, a total of 4,500 met the minimum 
requirements to enter the University of Nairobi and Kenyatta University College. The University, however, only admitted a total of 2,412 students (Daily Nation, Feb 14, 1982, p 3).

The importance of examination results in terms of opportunities for further education, training, and employment has been well documented by Kinyanjui (GR88). For example, in 1968, of a total sample of 1,186 secondary school leavers, 394 (33\%) were engaged in employment and 531 (41\%) were in school. Of those who were employed, $24 \%$ were from national schools, 38\% from provincial schools, and 37\% from Harambee schools. The remaining leavers were distributed accordingly: 531 (45\%) received further training, $175(14 \%)$ were unemployed, and $86(7 \%)$ were untraced. The overall unemployment rate for the group with Division I to III certificates was $6.9 \%$, but the unemployment rate among leavers from national schools with these certificates was $4.5 \%, 6.7 \%$ for leavers from provincial schools, and $28.2 \%$ for leavers from Harambee schools (GR85: 37). On the whole, the Harambee schools had the highest numbers of leavers remaining unemployed: $37 \%$ in the sample were unemployed in their first year after school, while smaller proportions from national and provincial aided schools fell into this category, as demonstrated in Table XXXXIV.

Unemployment in the second year after school was as follows: $86 \%$ for Harambee school leavers, 59\% for provincial school leavers, and 15\% for national school leavers.

EACE performance for the three types of schools was as follows: the mean grade aggregate was 31.0 for national schools, 35.7 for provincial schools, and 43.1 for Harambee schools (GR85: 38). On the basis 
of performance criteria, one might expect the distribution of opportunities for leavers from these three types of schools to be different, but the Harambee leavers experienced discrimination beyond that indicated by their lower performance on EACE. This discrimination also affected leavers from the less well-established government aided schools. While more than $60 \%$ of the leavers from aided national schools and about $42 \%$ from provincial schools went on to higher education or some form of formal training, only $18 \%$ of the leavers from Harambee schools continued their education or training. The implicatior is that more than $60 \%$ of Kenya's secondary school students are in the Harambee schools and are receiving an inferior education. Consequently, they cannot compete on an equal basis with students who attend government aided and urban high-cost schools. In short, the different school systems in Kenya have differential effects on social mobility.

TABLE XXXXIV

FIRST YEAR AFTER SCHOOL OPPORTUNITIES BY TYPE OF SECONDARY SCHOOL ATTENDED, 1968 SCHOOL LEAVERS

\begin{tabular}{|c|c|c|c|c|}
\hline $\begin{array}{c}\text { Type of After } \\
\text { School } \\
\text { Opportunity }\end{array}$ & $\begin{array}{c}\text { National } \\
\text { School } \\
\% \\
\end{array}$ & $\begin{array}{c}\text { Provincial } \\
\text { School } \\
\% \\
\end{array}$ & $\begin{array}{c}\text { Harambee } \\
\text { School } \\
\% \\
\end{array}$ & Total \\
\hline Higher Ed & 37.8 & 17.4 & 4.1 & 266 \\
\hline Training & 21.3 & 24.2 & 14.2 & 265 \\
\hline Employment & 24.7 & 37.8 & 32.7 & 394 \\
\hline Other Activities & 1.1 & 0.8 & 6.1 & 16 \\
\hline Unemployment & 9.2 & 14.5 & 36.7 & 175 \\
\hline Unknown & 6.4 & 5.3 & 8.2 & 70 \\
\hline Totals & $99.9(357)$ & $100.0(731)$ & $100.0(98)$ & 1,186 \\
\hline
\end{tabular}


POPULATION GROWTH, EDUCATION, AND MIGRATION

Population in Kenya over the past decade has grown at one of the highest rates in the world, $3.5 \%$ per annum. In real terms, Kenya's population grew from 11 million in 1969 to 16 million in 1979. At the present rate, it is expected to swell to 28 million by the year 2000 . The projections shown below in Table XXXXV are based on a declining birth rate. Should this not occur, total population in the year 2000 is projected at 34 million (KG5: 63).

TABLE XXXXV

POPULATION IN KENYA $(\%)$

\begin{tabular}{|c|c|c|c|}
\hline & & Estimated & Projected \\
\hline 1962 & 1969 & 1978 & 1983 \\
\hline
\end{tabular}

Age

Preschool

20

17

19

19

18

14

$(0-4)$

26

29

29

29

30

27

(5-14)

Economically

52

49

46

48

48

55

Active
$(15-59)$

Persons $60+$

2

5

6

4

4

4

$\frac{\text { Total Pop }}{\left(000^{\circ} \mathrm{s}\right)}$

$$
5,406
$$

$$
8,636
$$

10,943

74,732

17,470

28,182

Dependency

$92 \quad 104$

117

108

108

82

Ratio

Sources: (GR132: 208. Data for 1948, 1962, and 1969 are taken from the Population Census for these years. The estimate for 1978 and projections for 1983 and 2000 were obtained from KG5, Table 2.6, Declining Birth Rate Columns. 
The present population structure is indicated in Table XXXXV above. In $1978,48 \%$ of the population was under the age of fifteen, and only $3.7 \%$ was over the age of sixty. Hence, the population of productive age (15-59) was, in fact, smaller than the dependent population, comprising only $48 \%$ of the total. As a result, the dependency ratio (the number of people dependent on each one hundred persons of working age) increased steadily from 92 in 1948 to 117 in 1969, and then began to drop. The projected dependency ratio for the year 2000 is 82 . The school age population was $29 \%$ in 1978 , which, combined with the other developments, suggests that there will be an increased demand on the government to provide sufficient quality education and productive employment. The impact of this demand is expected to place tremendous strain on both governmental and family budgets.

It is estimated that $90 \%$ of Kenya's 16 million people live in rural areas and earn their livelhood from peasant agriculture. Because of demographic and land tenure patterns, access to land has become limited in recent years. According to the latest Development Plan (KG5), less than $17 \%$ of Kenya's land area is considered arable (i.e., high and medium potential land). The average overall population density was 26 per sq kilometer in 1978, while the density on arable land was 135 per sq $\mathrm{km}$. By the year 2000, these densities are anticipated to be 50 and 250 per sq $\mathrm{km}$, respectively (KG5: 65). Already, approximately $30 \%$ of Kenya's households do not have access to land. Land is concentrated in a very few hands. Njonjo (GR117) reports in his 1974 survey of 230 large farms occupying 222,000 acres, representing about $67 \%$ of the total African-owned mixed farmland, that the smallest $91 \%$ of the 
farmers owned only $21 \%$ of the land and the largest $5 \%$ owned $69 \%$. Most of the landless in Kenya are too poor to be able to set up a business. Even those with access to some land have a hard time generating subsistence-level income.

The increased drain on the land and the relatively low income of rural peasants create a situation in which the vast majority of rural peasants are forced to migrate to other, more prosperous rural areas or urban centers. The significance of such migration is shown in Table XXXXVI, which indicates the proportion of casual labor in the formal sector. The table shows that $50 \%$ of the casual labor is employed in agriculture and forestry; about $15 \%$ is employed in manufacturing. The high percentage of casual labor in the sugar and coffee plantations reflects seasonal peaks as in coffee picking. On the whole, the data indicate that casual labor is a major source of supplementing low incomes in rural Kenya. Given the implied expansion in the adult workforce and the comparatively small proportion of medium and high potential land, this raises major questions of future employment and labor migration.

Livingstone (GRT07) has identified three kinds of population movements in Kenya: rural-urban migration; rural-rural migration; and reverse urban-rural migration of returning migrants. Rural-urban migration has been the main focus of attention because of its association with the problem of urban unemployment (GR132; GR150).

In the 1960's and the early 1970's, rural-urban migration to Nairobi was nearly $17 \%$ per annum. The 1972 ILO Mission to Kenya was particularly concerned with this problem because of its possible impact 
TABLE XXXXXVI

PERCENT OF CASUAL LABOR IN THE FORMAL SECTOR, 1977

\begin{tabular}{|c|c|c|c|}
\hline & $\begin{array}{c}\text { Casual Workers } \\
\text { in Industry } \\
\text { \# }\end{array}$ & $\begin{array}{c}\text { Casual Sector } \\
\text { Employment } \\
\% \\
\end{array}$ & $\begin{array}{c}\text { All Casua } 1 \\
\text { Labor } \\
\% \\
\end{array}$ \\
\hline$\frac{\text { Agriculture \& }}{\text { Forestry }}$ & 35,134 & 32.7 & 51.1 \\
\hline $\begin{array}{l}\text { Sugar Plantations } \\
\text { Mixed Farming } \\
\text { Coffee Plantations } \\
\text { Sisal Plantations }\end{array}$ & & $\begin{array}{l}54.8 \\
46.0 \\
44.0 \\
15.0\end{array}$ & \\
\hline Mining \& Quarrying & 1,567 & 46.7 & 0.9 \\
\hline Manufacturing & 24,625 & 20.9 & 14.8 \\
\hline $\begin{array}{l}\text { Food Products, mec } \\
\text { Soap, etc } \\
\text { Plastic Products }\end{array}$ & & $\begin{array}{l}32.5 \\
36.3 \\
35.1\end{array}$ & \\
\hline Electricity \& Water & 3,511 & 36.3 & 2.1 \\
\hline Water works \& supply & & 46.0 & \\
\hline Construction & 11,153 & 23.1 & 6.7 \\
\hline 0ther & 40,629 & & 24.4 \\
\hline $\begin{array}{l}\text { TOTAL } \\
\text { A11 industries }\end{array}$ & 166,619 & 18.5 & 100.0 \\
\hline
\end{tabular}

Sources: (GR69: 5-16; GR707. Compiled from Central Bureau of Statistics, Employment and Earnings, 1977, p 11).

on urban unemployment. The Mission projected that a major urban avalanche would take place in Kenya during the 1980's; however, the anticipated explosion in the number of urban unemployed in Nairobi has not materialized. One reason has been a considerable growth in large numbers of other towns in Kenya which have absorbed the anticipated migration to 
Nairobi. As indicated in Table $X X X X V I I, 12$ towns grew faster than Nairobi, and 14 grew faster than Mombasa. Kakamega and Kisii grew at nearly $18 \%$ per annum--phenomenal growth rates. Reflecting this general dispersal of urban growth, the proportion of the population in towns of 10,000 or more accounted for by Nairobi and Mombasa appears to have fallen from $81.6 \%$ in 1969 to $60.7 \%$ in 1979 , a dramatic change. This change in urban population, however, has not been accompanied by a corresponding increase in the distribution of manufacturing establishments and wage employment. In 1978, Nairobi and Mombasa together accounted for $73 \%$ of wage employment and $69 \%$ of manufacturing employment in main towns (KG7, 1978). Given the historical concentration of manufacturing and commercial activity in Nairobi and Mombasa, these two urban centers are expected to attract the majority of migrants, particularly those with several years of formal education. One feature of rural-urban migration is that it tends to be selective, with a bias towards the younger age groups and toward those who have had some education. This may be due either to raised expectations among the educated or to the greater probability of securing a job in the case of migrants with some years of education. A corollary of the latter is that as more of the populace acquire education, the degree of education required for a given probability of employment will increase. Thus, following the dramatic expansion of education after independence and the gradual slowing down of the rate of growth of industrial employment in the late 1960's and 1970's, unemployment among school graduates has reached epidemic proportions. In an extensive study of labor migration by male students and 
TABLE XXXXVII

RATE OF GRONTIH OF MAIN TOWNS (OVER 10,000) 1969-79

\begin{tabular}{|c|c|c|c|}
\hline Ma in Towns & 1969 & 1979 & $\begin{array}{l}\text { Annual Rate } \\
\text { of Growth } \\
1969-1979 \\
\end{array}$ \\
\hline Kakamega & 6,244 & 32,000 & 17.8 \\
\hline Kisij & 6,083 & 31,000 & 17.7 \\
\hline Kisumu & 32,431 & 150,000 & 16.6 \\
\hline Nyeri & 10,004 & 36,000 & 13.7 \\
\hline Kericho & 10,144 & 30,000 & 11.5 \\
\hline Eldoret & 18,196 & 50,000 & 10.6 \\
\hline Kitale & 11,573 & 28,000 & 9.2 \\
\hline Thika & 18,387 & 41,000 & 8.4 \\
\hline Malindi & 10,757 & 23,000 & 7.9 \\
\hline Nakuru & 47,151 & 93,000 & 7.0 \\
\hline Athi River & & 10,000 & 6.5 \\
\hline Nanyuki & 11,624 & 19,000 & 5.0 \\
\hline Nairobi & 509,286 & 828,000 & 5.0 \\
\hline Naivasha & $6 ; 920$ & 11,000 & 4.7 \\
\hline Nyahururu & 7,602 & 11,000 & 3.8 \\
\hline Mombasa & 247,073 & 342,000 & 3.3 \\
\hline Isiolo & 8,201 & 11,000 & 3.0 \\
\hline
\end{tabular}

Sources: (KG7, 1969 and Central Bureau of Statistics Provisional Estimate, 1979)

urban unemployment in Kenya, Rempel (GR132) found a relationship between a migrant's education and his propensity to migrate to an urban center. * The data presented in Table XXXXVIII, next page, indicate that $25 \%$ of the migrants have some secondary education, while an additional $47 \%$ have 5 to 8 years of formal schooling. of those with 5 to 8 years of education, $75 \%$ appear to have completed primary education. For ilairobi, $34 \%$ of the migrants have some

\footnotetext{
The sample excluded female students because of their low rate of migration, resulting from a number of cultural sanctions which act as prohibiters. The fear of being stigmatized as a "prostitute" is one such example.
} 
secondary education, while an additional $42 \%$ have 5 to $\&$ years of formal schooling.

\section{TABLE XXXXVIII}

PERCEINTAGE DISTRIBUTION OF LEVELS OF EDUCATIONAL ATTAINMEINT FOR MEN WHO MIGRATED TO EACH OF THE EIGHT URBAIN CENTERS

Education

\begin{tabular}{|c|c|c|c|c|}
\hline \multirow[b]{2}{*}{ Urban Centers } & \multirow[b]{2}{*}{$\begin{array}{l}\text { No Formal } \\
\text { Education }\end{array}$} & \multicolumn{2}{|c|}{ Standards } & \multirow{2}{*}{$\begin{array}{l}\text { Forms } \\
1-6\end{array}$} \\
\hline & & $1-4$ & $\underline{5-8}$ & \\
\hline Nairobi & 10.8 & 13.5 & 41.7 & 34.0 \\
\hline Mombasa & 15.8 & 18.4 & 50.1 & 16.1 \\
\hline Kisumu & 11.6 & 21.7 & 45.8 & 20.9 \\
\hline Nakuru & 17.5 & 12.7 & 55.5 & 14.3 \\
\hline Eldoret & 30.8 & 9.6 & 38.5 & 21.1 \\
\hline Thika & 5.0 & 7.5 & 52.4 & 35.0 \\
\hline Nanyuki & 10.0 & 12.0 & 68.0 & 10.0 \\
\hline Nyeri & 7.6 & 12.7 & 45.5 & 34.2 \\
\hline Totals & 12.7 & 14.8 & 47.1 & 25.4 \\
\hline
\end{tabular}

The age characteristic of migrants is given by Whitelaw (GRT67). According to the data presented in Table XXXXIX, the typical migrant tends to be very young, with several years of education.

Rempel also noted a significant variation in the distribution of the levels of educational attainment among provinces of migrant births. For example, the Central and Nyanza Provinces contain a proportionally higher population concentration in the secondary education group, while Coast and Eastern Provinces contain a low concentration. On the other hand, Eastern and Rift Valley Provinces contain a 
proportionally greater population concentration with no formal

schooling, while Coast and Nyanza Provinces contain the proportionally greater concentration of people with some primary education. This variation could be the result of differences among provinces in the availability of employment opportunities in rural areas or in the quality of primary education, which determines a student's ability to compete for the limited number of secondary school seats available in Kenya.

TABLE XXXXIX

PROPORTION OF AFRICANS SEEKING WORK IN NAIROBI, BY AGE A:VD LEVEL OF EDUCATION

1970 (PERCENTAGES)

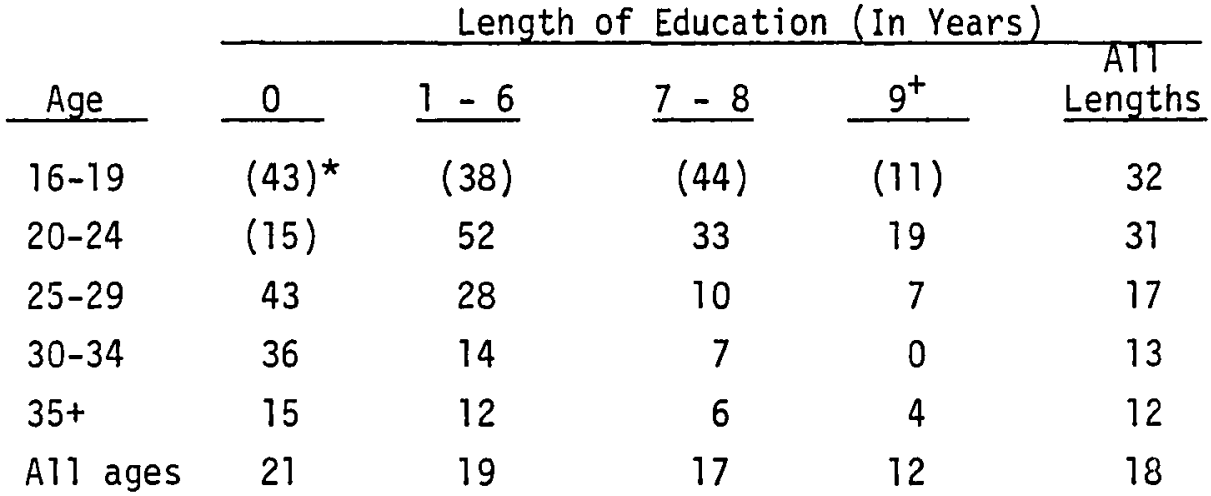

* Parenthesized figures indicate less than 25 observations in cell. Persons not specifying age or education were excluded.

Source: (GRT67)

The most important population activity in the quarter prior to migration was determined to be the obtaining of an education (47.4\%). Only a small proportion of the population (16.6\%) was engaged in farming. An additional $19.6 \%$ were employed for wages, which may or 
may not have been on a farm. This suggests that those with some years of formal education may choose to take a risk and decide to migrate; those with no formal education are much less likely to do so. The following, Table $L$, shows the percentage distribution of the various employment categories prior to migration.

TABLE L

THE PERCENTAGE DISTRIBUTION OF THE NATURE OF EMPLOYMENT OF MEN PRIOR TO THEIR RURAL-URBAN MIGRATIOIN

\begin{tabular}{|c|c|c|c|c|c|c|c|}
\hline \multirow[b]{2}{*}{$\begin{array}{c}\text { Province of } \\
\text { Birth } \\
\end{array}$} & \multicolumn{6}{|c|}{ Nature of Employment } & \multirow[b]{2}{*}{ Totals } \\
\hline & $\begin{array}{c}\text { In } \\
\text { School } \\
\end{array}$ & $\begin{array}{c}\text { Empl for } \\
\text { Wages } \\
\end{array}$ & $\begin{array}{l}\text { Self- } \\
\text { Empl }\end{array}$ & Farming & $\begin{array}{l}\text { Empl } \\
\mathrm{P} / \mathrm{T} \\
\end{array}$ & Unemp1 & \\
\hline Urban Center & 41.4 & 20.7 & 3.5 & 13.8 & 10.3 & 10.3 & 100 \\
\hline Nyanza & 48.9 & 15.1 & 4.8 & 16.5 & 3.5 & 11.2 & 100 \\
\hline Western & 41.8 & 18.6 & 2.3 & 20.9 & 2.8 & 13.6 & 100 \\
\hline R Valley & 53.8 & 15.4 & 7.7 & 2.6 & 5.1 & 15.4 & 100 \\
\hline Central & 54.4 & 14.5 & 3.5 & 9.6 & 3.2 & 14.8 & 100 \\
\hline Eastern & 39.9 & 14.6 & 4.4 & 27.8 & 4.4 & 8.9 & 100 \\
\hline Coast & 50.0 & 14.5 & 3.9 & 22.4 & 2.6 & 6.6 & 100 \\
\hline $\begin{array}{l}\text { Uganda and } \\
\text { Tanzania }\end{array}$ & 21.9 & 31.2 & 12.5 & 18.8 & 3.1 & 12.5 & 100 \\
\hline Totals & 47.4 & 16.0 & 4.2 & 16.6 & 3.6 & 12.2 & 100 \\
\hline
\end{tabular}

On the basis of this study, a typical migrant is determined to be relatively young, will likely have completed more formal education than the average Kenyan of the same age, and will have less actual or potential ciaim to land ownership than the average Kenyan. Conclusive evidence is presented to support the claim that the propensity to migrate increases with the level of educational attainment. 
Thus, Kenya's continued efforts to expand educational opportunities will likely increase the internal migration flows.

EDUCATIONAL STRATEGIES FOR IMPROVING URBAN EMPLOYMENT: THE KENYAN EXPERIENCE

That Kenya has achieved a high rate of expansion in primary and secondary education has been well documented in Chapter II. The unprecedented growth in primary and secondary school enrollment achieved so far has led to the emergence or accentuation of unemployment problems among school graduates. Measures to deal with the unemployment of school leavers have been taken at two levels: from within the formal educational system and from outside it. Reforms within the educational system have concentrated on curriculum changes and the expansion of institutions to provide technical and agricultural education (GR37; GR92; GR93). Outside the formal educational system, measures intended to alleviate the unemployment problem have ranged from land settlement schemes to direct intervention in the labor market through tripartite agreements, and more recently, from wage guidelines set by the Industrial Court, and through the taking of jobs held by nonresidents (GRI4E).

The central component of the school leaver problem, as perceived by planners and politicians, is the so-called "white-collar mentality" fostered by the educational establishment which makes youngsters set their sights on the limited number of civil service and management jobs available and causes them to reject agricultural or manual work (PI3-5, 12, 15). This attitude is cited as a major cause of 
unemployment. According to an editorial which appeared in the Daily Nation:

The trouble with our educational system is that it just isn't suited to our development programme. In its original form, the system was designed to produce a small group of clerical 'yes men' who would help perpetrate colonialism in Kenya. And the disheartening thing is that this sorry state of affairs has been allowed to continue up ti11 now--13 years after Kenya became an independent nation ... What this means is that the educational system cannot play its role as the nerve centre of our development process. It achieves a spectatory role rooted in its colonial mess. It cannot take an innovative role ... So, yearly we are producing school leavers whose most important qualification is the ability to speak English with an anachronistic oxford accent. And the baffled kids, waiving certificates that don't mean much, flock into urban areas where they hope to get white-collar jobs and practice their oxford English. And so we end up with 'educated' but unemployable kids who, because they have no skills, start loitering in urban areas with imponderable consequences. The solution to this problem lies in reforming the educational system to give it a rural orientation (emphasis added).

(January 19, 1982: 6)

The general theory behind this style of thinking is that unemployment in this case is due to an educational system which turns out inappropriately trained labor, i.e., labor which is academically geared. The colonial legacy in the educational structure, which ensures that an elite is groomed for administration is often blamed for producing this situation. The solution, therefore, appears to lie in a reform of the educational system by promoting vocational and practically-oriented training such as the Village Polytechnic Programme (PI 1-15). Instead of fostering aspirations for passing examinations and gaining white-collar jobs, this program imparts the skills necessary for gaining local craft employment. In other words, 
the new orthodoxy advocated changes in the different components of the school system particularly curriculum reform, thus maintaining intact the main elements of the colonial educational and economic structures.

A recurring theme all these reforms suggest is the view that education and production ought to be closely linked. The integration of education and production is expected to discourage students from seeking employment in the urban areas and lead them into rural areas where employment is considered plentiful (GR3; GR37). In Kenya, this thinking was originally spawned by the National Christian Council of Kenya (NCCK) in the mid-1960's. One of its pioneering reports, entitled After School What? (GR115) focused attention on the hundreds of thousands of primary school leavers $(67,000$ in 1964) who had little hope of finding higher wage employment or further education, yet who were unprepared in terms of knowledge, skills, or expectations for the rural environment into which they were left. The report was subsequently discussed at an international Conference on Education, Employment and Rural Development, held in Kericho, Kenya, in March 1966 (GRT41). One of the solutions proposed was the establishment of Village Polytechnics to equip primary school leavers with simple, practical skills such as masonry and carpentry, which could be utilized locally in a self-employed capacity. The idea is that if polytechnic graduates establish themselves in business locally, possibly using skills which are new to the area, they will be creating new jobs (hence bringing down the unemployment rate) and retaining and bringing additional income into the community (hence developing 
the rural economy); the combined effect wi11, in turn, lower the rate of rural-urban migration.

Many of these reforms are to be welcomed on strictly educational grounds. Nevertheless, it is doubtful whether they wi11 succeed in having any major impact on the school leaver problem, and in particular whether they will succeed in halting the pressure for expanding upper secondary and higher education, ignoring as they do the earnings that regularly accrue to persons with advanced levels of schooling in Africa (PI 8 ; PI 11). The appeal of standard examinations stems not merely from the wish of students to achieve entrance to higher education, but also from the very high earnings and status associated with jobs to which higher levels of education give access.

In Kenya, for example, educationally qualified people with relatively low skills can earn incomes that are large multiples of minimum formal sector wages (GR68: 271). According to a recent ILO report (GR70: 11), a high school graduate (EACE certificate), for instance, may take a two-year certificate or a three-year diploma in an agricultural field. At the end of the first training period that graduate would earn $\mathrm{K} t 35 \mathrm{l} /$ - in Job Group E, with a title of Technical Assistant, Agriculture. At the end of the second year, he would earn $\mathrm{Kt} 854 /$ - in Job Group $G$, with a title of Agricultural Extension Officer. An extra year of learning simply awards him two promotions within the same salary structure, amounting to about a $63 \%$ increase in salary. The difference for one year's earning, Kt 303/- (i.e., Kt 864/less $K t 531 /-)$, is nearly equal to the total annual salary of a Kenyan with seven years of primary education. In a study of 
entrepreneurship and development, Marris and Somerset (GR110)

concluded that Kenya is a society in which rewards for the educationaliy qualified in employment far exceed the returns of all but the most successful entrepreneurs. The roots of the unemployment problem, therefore, lie in the interaction of the conventional educational system and the wage and salary structure through the allocation of jobs and wages by reference primarily to educational qualifications (GR69: 11). This has led to a great desire for education at every high level, such education being associated in the minds of the public with income aspirations and expectations which the economy is becoming increasingly unable to fulfill.

While changes in curriculum and in systems of selection may be expected to bring educational benefits, it is unrealistic to suppose that such changes will make people content to accept work at very low incomes in rural areas if they believe themselves to be eligible for highly-paid urban jobs. As Colclough and Hallack succinctly put it:

Fundamental educational change may not be possible in many societies without a significant change in the existing structure of economic and social relationships--and particularly in the incentives structure that directly links the educational sector to the labour market.

(GR35: 20)

In short, as long as employers continue to use the level of education attained as the main criterion for hiring recruits and as long as the existing income differentials between the highest and lowest paid jobs in the occupational hierarchy remain somewhat what they are, the phenomenon of educated unemployment in Africa is unlikely 
to be more than marginally affected by even major changes in the qualitative aspects of education.

THE SCOPE OF INDUSTRIAL TRAINING IN KENYA

Policymakers in Kenya have rationalized the unemployment situation among school leavers as that of graduates lacking marketable skills to participate effectively in modern sector employment (PI 3, 4, 12). This has led to the establishment of various forms of industrial training activities, combining both public and private initiatives. The diversity of current involvement in policy for and provision of training in Kenya is presented in Figure 10 (next page). In general, these activities can be classified into three component parts (GR92):

(a) Supplementary Programs are designed to supplement the formal educational system. Some are aimed at character building and the formation of appropriate attitudes; others develop particular skills that may or may not be relevant to the needs of Kenyan youth. Many are local branches of international organizations and are aimed at the school-going population. The following are typical of this category:

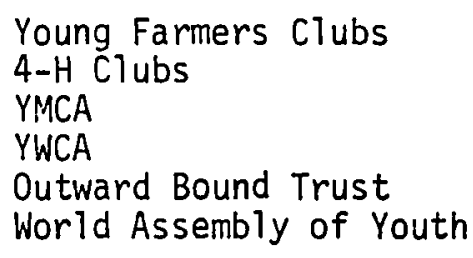



(b) Follow-up Programs attempt to provide primary school leavers with some form of training and education that will equip them with 

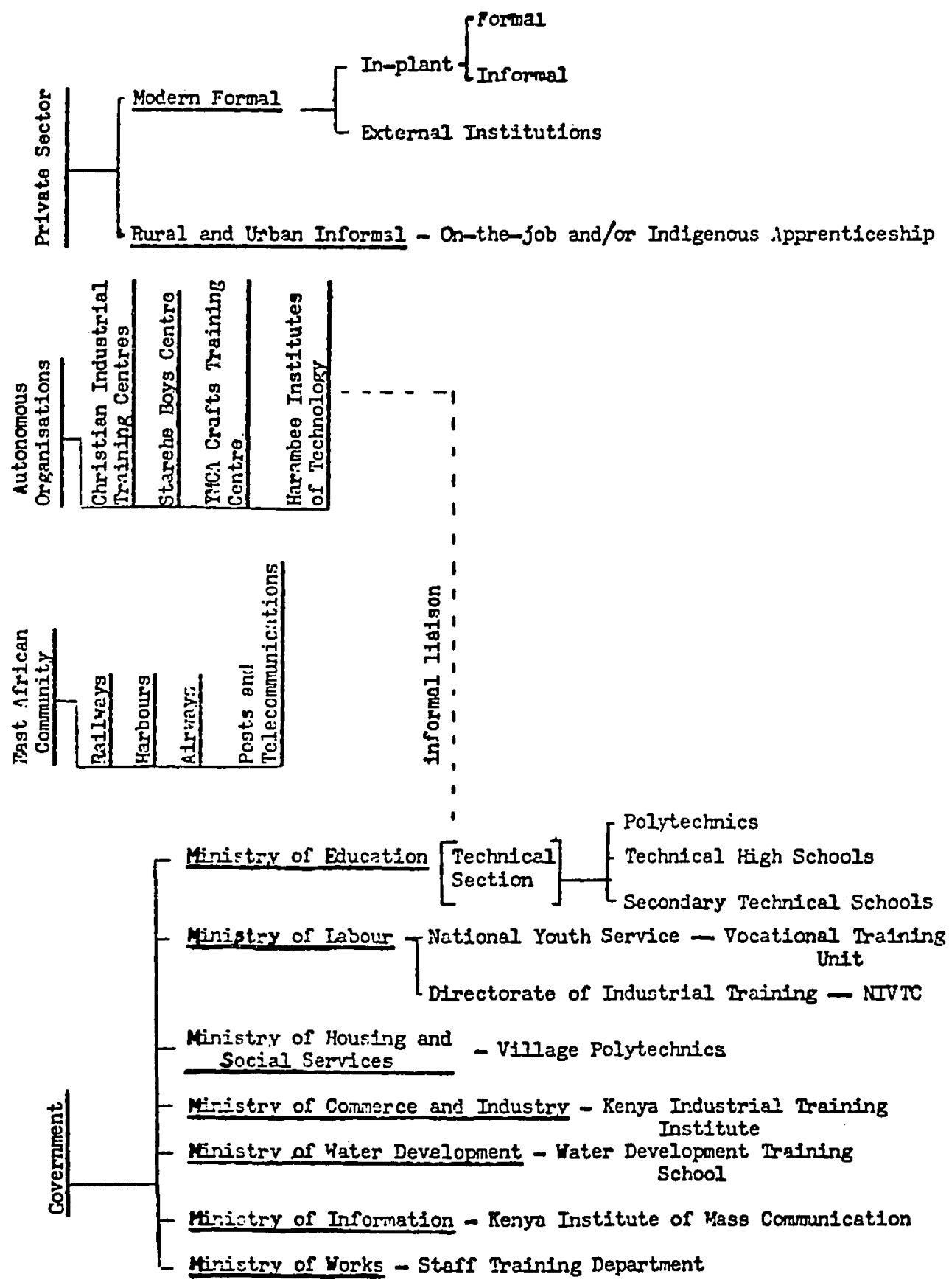

Figure 10. Domains of Industrial Training Activity--1975. 
skills for employment or self-employment, preferably in the rural areas. They include:



(c) Alternatives to Formal Education are for the unschooled who are not covered by other educational programs. They basically take the form of literacy classes and are run by various organizations such as:

Youth Clubs and Centers Farmer and Rural Training Centers Maendeleo - Progress for Women

In this section, the focus will be on the follow-up programs which provide vocational training for primary and secondary school leavers. Specifically, the impact of the Village Polytechnics and Secondary Technical Training programs are examined in detail. The careful examination of the village polytechnics and industrial training for secondary school leavers indicates that these programs are not realizing their aims because of the restricted market for technical and vocational skills in the country.

\section{The Village Polytechnics}

The village polytechnic movement has thus far been the most popular program for alleviating unemployment among primary school leavers, attracting both state and international financial support (GR7; GR50; GR93). Following the Kericho conference, the NCCK set up four village polytechnics--at Maseno in Western Province, at Mucii-wa-Urata 
in Central Province, ivdere in Nyanza Province, and Nambale in Western Province (GR93: 190). Since then, the number of projects has increased to 300 including, in addition to the ones receiving governmental funding, those projects financed entirely by the church, by contributions from local authorities, by foreign aid donations, and by Harambee collections. The number receiving government funding is currently 220 , as shown below in Table LI, which gives some idea of the growth rate of the program ( 30 projects being added each year). Plans have been made to continue expansion at the same rate until 1985 (GR24).

TABLE LI

EXPANSION OF POLYTECHNIC PROGRAM*

\begin{tabular}{|c|c|c|c|}
\hline Year & $\begin{array}{c}\text { \# of } \\
\text { Projects } \\
\end{array}$ & $\begin{array}{c}\# \text { of } \\
\text { Tra inees } \\
\end{array}$ & $\begin{array}{c}\# \text { of } \\
\text { Instructors }\end{array}$ \\
\hline $1973 / 74$ & $75^{\star \star}$ & $4,000^{\star \star}$ & $375^{\star \star}$ \\
\hline $1975 / 76$ & 130 & 7,000 & 650 \\
\hline $1976 / 77$ & 160 & 9,000 & 800 \\
\hline $1977 / 78$ & 190 & 11,000 & 950 \\
\hline $1978 / 79$ & 220 & 14,000 & 1,100 \\
\hline $1979 / 80$ & 250 & 20,000 & 1,250 \\
\hline $\begin{array}{l}1984 / 85 \\
\text { (Projected) }\end{array}$ & 400 & 30,000 & 2,000 \\
\hline
\end{tabular}

* Table shows increases in Number of Trainees/Instructors/ Projects, 1973/80

** Commonwealth Youth Development Programme, March 1975, p 115. Youth for Development: an African Perspective

Source: (GR37:115) 
The above table indicates that during the period 1973-30, the number of projects has almost quadrupled, whereas the number of trainees has grown five fold. It is questionable whether the number of graduating artisians will all be absorbed into the labor market, given the slow rate of economic growth in the country. The situation is made more acute by the existence of other institutions offering similar training to the polytechnics, such as the National Youth Service, Christian Industrial Training Centres, The Kenya Association of Youth Centers, centers run by the YMCA and YWCA, Approved Schools and Technical Secondary Schools, as well as various types of formal and informal apprenticeship and on-the-job training programs.

The considerable expansion of the Village Polytechnic Program that has occurred over the past decade has undoubtediy been promoted by the adoption of a regional rural development strategy (KG3). This development plan referred to Village Polytechnics as part of a broad policy of youth training and rural development. The approach, as the name suggests, focuses on rural development; in order to achieve this development, increased output in the small holder farmer sector, the wide scale adoption of appropriate technology (GR147), promotion of informal sector activity (GR69), and decentralization of decisionmaking are being advocated. The emphasis on rural development is a reaction against the industrialization policy of the 1960's which failed to produce sustained economic growth and expanded employment opportunity. This new approach, however, should not be seen as a substitute for an industrialization policy; rather, it is complementary to an industrialization policy, and both are essential elements in a comprehensive 
development plan.

The most common courses offered by the polytechnics are carpentry (21\%) and Masonry (19\%) for boys and tailoring/dressmaking $(19 \%)$ and home economics (16\%) for girls (GR158: 25). Other courses include: commerce (including bookkeeping, accounting, and typing), leatherwork (including tanning and shoe making), metal work/tinsmithing, welding and fitting, motor mechanics, agriculture (including animal husbandry, horticulture, and beekeeping), painting and technical drawing. Courses are usually two years in length, and governmental trade tests may be taken at the end. Fees vary from Kshs. 50/- to Kshs. 800/- per year (GR24: 17).

The Village Polytechnic program got underway officially in 1971 with financial support for 40 VP's from NCCK and other voluntary agencies (GR37: 115). Then, in the early 1970's, the Kenyan government became involved in the project in both a financial and an administrative capacity. In 1973-74, the government spent just over KL210,000 on the Youth Development Program, including Village Polytechnics and the lower level youth centers, and approximately $\mathrm{KL}$ 154,000 was provided from overseas (GR37: 117).

Today, the government is the major source of finance and pays all staff salaries, though funds from other sources remain important for buying materials and equipment and paying for new buildings. It remains the case that a new project must be funded from nongovernment sources for a certain period as a test of local support and its viability; if it is successful, generally the government will eventually adopt it. 
The ultimate test of the village polytechnics has been what happens to the graduates after they complete their training. The results of previous research on the subject have been mixed. Mackie (GR109), for example, reported that of 24 leavers from one pioneer village polytechnic, only 3 had followed the anticipated route to self-employment in the trade they learned, while 11 had returned to formal education. In a subsequent study, Anderson (GRI1) reported that $30 \%$ of the polytechnic leavers he traced had migrated to urban areas and almost $37 \%$ of those who were then employed had migrated. These studies suggest that the village polytechnics had failed to realize their aims. On the other hand, other researchers have reported that graduates of polytechnics were able to find employment or start their own businesses. The Horad Report (GR120) uses the figures of 50-75\%; and David Court (GR39) reported that at least $90 \%$ of the males trained in the village polytechnics in Western Kenya found employment, but the percentage figures for females were extremely low. This raises the problem of defining realistic goals for the training of females since their entrepreneurial opportunities are subject to stricter cultural sanctions in rural areas than is the case for males. The last two studies, in particular, should be examined carefully since they exaggerate the percentages that were self-employed. The nature of rural life in Africa requires that every member of the family participate in the production of goods and services, and this pattern of 1 ifestyle may have distorted the outcome of the above quoted studies.

The most up-to-date study on the whereabouts of village polytechnic 
graduates was conducted by Brian Calpen and the Ministry of Labor (GR24), based on information derived from two tracer studies carried out in two communities of rural Kenya. The aim of the study was to test the hypothesis that a substantial number of polytechnic leavers would be unable to take up the type of employment envisaged because of the limited absorptive capacity of the informal sector in rural areas. It was felt that the demand for skilled artisans in rural areas is limited by the level of development of the area concerned (GR24: 1). Furthermore, it was considered that even if there were sufficient demand, the leavers might be unable to fully exploit their potential because of the lack of raw materials, tools, and credit to start their own businesses. The question was then asked: Is the provision of training by itself sufficient to engender this type of development, or are other kinds of assistance also necessary?

The hypothesis was then tested by carrying out surveys of the polytechnic leavers in two communities. One survey was undertaken in an economically vibrant area (Othaya in North Central Kenya), with a good demand structure; the other was accomplished in Kenenya (in Southwest Kenya), a less prosperous district with lower demand. By comparing the two sets of data, it was possible to assess the impact of the demand level on the fortunes of the leavers. Predictions were that the program might be relatively successful in the high demand area (i.e., Othaya), but less so in Kenenya. The aggregate results of the leavers' surveys for both polytechnics are presented in the table that follows.

One striking feature of Table LII is the small percentage (9\%) 
TABLE LII

SUMMARY OF EMPLOYMENT FOR VOCATIONAL SCHOOL GRADUATES

IN KENENYA AND OTHAYA*

\section{Categories}

Self-Employed:

Self-sufficient $(80 \%+)$
Borderline $(50-80 \%)$
Unclassifiable
$\quad$ Total Self-Employed

Farming

Rural Wage Labor

Towns

Unknown

Other

Total

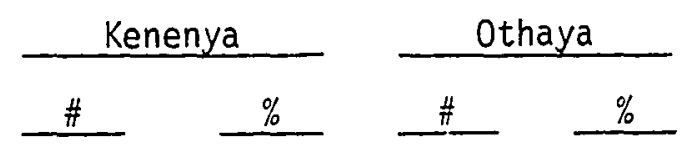

22

21

11

54

55

5

39

41

28

222

$\begin{array}{rrr}10 & 16 & 8 \\ 9 & 12 & 6 \\ 5 & 13 & 7 \\ 24 & 41 & 21\end{array}$
6 7 
of these self-sufficient artisans would be able to survive solely with income earned from their craft during a slump time. The table also shows that $26 \%$ of the leavers were found to be deriving the majority of their income from farming, as they would have done had the polytechnic not been there. They may use their polytechnic skills to improve their land or to earn some extra pocket money by helping out with a local contract, but their chief occupation is farming. So what the polytechnics are doing in these cases are graduating, not self-employed artisans, but better-grade peasant farmers. This and the prevalence of agriculture as a compulsory subject in polytechnics is indicative of how the program is in some ways a training for rural life rather than providing a breeding ground for tomorrow's entrepreneurs.

The significant difference between the two sets of results which can be noted at this stage is the much higher percentage of Othaya's leavers who got local salaried jobs-- $12 \%$ compared with Kenenya's $2 \%$. Considering the difference in employment opportunities available in the two communities (0thaya being more heavily endowed with wage labor posts), this is not surprising.

Complicating the problem still further is the lack of government financial assistance to the graduates. The revolving loan fund established by NCCK from which VP graduates could purchase tools and equipment was too small to make a significant impact. For example, the maximum loan of Kshs. 2,000/-per graduate was too small to score large contracts estimated to be around Kshs. 50,000/- (GR24: 63). This point illustrates the difficulty of getting started in self-employment 
regardless of one's technical skills,

The overall conclusion that can be drawn from the analysis is that the Village Polytechnic program is not substantially realizing its aims. These schools provide training opportunities for less than $5 \%$ of the total number of school leavers not admitted into secondary schools, and the chances of self-employment for those trained in these institutions is determined by the social and economic development taking place in each rural community. As a result, these schools are unlikely to provide a solution to the serious unemployment problem facing the country. As the data have indicated, only a small proportion of leavers are becoming self-employed; and of those who do become self-employed, the majority are unable to expand their businesses signficantly due to a lack of government support in the areas of credit extension and protection from multinational competition. Therefore, the rural economy is not being developed as planned. This failure is clearly due to economic factors, e.g., limited and nonexploitable demands which obviate an earlier key statement that changes in the educational structure alone are insufficient to bring about the program's aims. The provision of training must be accompanied by other forms of assistance. Rapid transformation of the rural economy will be critical to the functioning of the village polytechnics, even at the limited level at which they are now operating.

\section{Technical Training for Secondary School Leavers}

Secondary school is the only aspiration of many children, because it is from secondary school that other viable openings in life (teacher 
training, employment in commerce, recruitment into the Armed Forces, and so on) become real possibilities. Since 1968, however, the problem of the secondary school leaver has been acute, particularly in the case of those from the Harambee secondary schools. Despite this, a new optimism emerged in the 1970's which argues that the only real security could be found in a technical qualification. Once again, international aid and self-help efforts were directed toward building new vocational schools and technical colleges (GR57). The result was the same tale once again: the first students emerged from the technical schools in 1970 and were absorbed into Nairobi's Industrial Estate--the government's technical ministries. Many of the next group (from the class of 1971) were still walking the streets in early 1973 (GR84). The situation has worsened since the mid-seventies. At first, it was suggested that secondary technical school graduates would have a better chance of obtaining employment than students with academic secondary training. Because of the country's drive toward industrialization, it seemed certain that the expanding manufacturing sector would absorb the graduates of technical schools. But as these jobs in the MES became scarce, the government began to emphasize the importance of technical training for self-employment. A political rationale replaced the economic ones. Like their counterparts (the graduates of village polytechnics), the secondary technical school graduates were asked to accept employment in rural areas.

In the absence of an up-to-date tracer study, it is difficult to examine what happens to technical school leavers. In 1975 and 1976, the technical education section of the Ministry of Education attempted 
to follow up secondary technical school leavers from the previous year to find out what had happened to them.* The surveys have certain weaknesses (notably the low response rates--42\% and $51 \%$ respectively-and the short time that had elapsed since the graduates had left school), but they represent the most complete set of information available pertaining to outcomes. The most useful table in each of the surveys is that showing the status of secondary technical school leavers after the Directorate of Industrial Training had completed its recruitment of craft apprentices. Table LIII combines that information for both years.

The DIT apprenticeship program, to which the technical schools are supposed to be geared, took only a small proportion of school leavers in both years, leaving the majority to find their own ways in the job market. It would be wrong to conclude from Table LIII alone, however, that a large proportion of the technical school graduates are destined for chronic unemployment. Both 1974 and 1975 were years of recession for the Kenyan economy. This does not mean that the economy has rebounded since then. Moreover, school leavers spend several months waiting for their EACE results before deciding on their best job market strategy.

A question that must be considered is what the optimal allocation of public resources among the various forms of education should be. Which parts of the system should be marked out for emphasis in the

Technical Education Section, 1974 Secondary Technical School Graduate Follow-up Study, Summary of Findings, August, 1975; and 1975 Technical Secondary School Graduates Follow-up Study, Summary of Findings, October, 1976. 
TABLE LIII

SECONDARY TECHNICAL SCHOOL GRADUATES' STATUS AFTER DIT INTAKE, 1974 AND 1975

\begin{tabular}{|c|c|c|c|c|c|c|c|c|c|c|c|c|c|c|}
\hline & \multicolumn{2}{|c|}{ Student } & \multicolumn{2}{|c|}{$\begin{array}{l}\text { Working \& } \\
\text { and going } \\
\text { to school }\end{array}$} & \multicolumn{2}{|c|}{ Military } & \multicolumn{2}{|c|}{$\begin{array}{l}\text { Employed } \\
\text { or } \\
\text { self-empl }\end{array}$} & \multicolumn{2}{|c|}{$\begin{array}{l}\text { Looking } \\
\text { for } \\
\text { work }\end{array}$} & \multicolumn{2}{|c|}{ Other } & \multicolumn{2}{|c|}{ Total } \\
\hline & 1974 & 1975 & 1974 & 1975 & 1974 & 1975 & 1974 & 1975 & 1974 & 1975 & 1974 & 1975 & 1974 & 1975 \\
\hline Mechanical & 8 & 10 & 39 & 38 & 2 & - & 10 & 19 & 39 & 28 & 2 & 5 & 100 & 100 \\
\hline Electrical & 15 & 14 & 18 & 16 & - & - & 2 & 8 & 63 & 57 & 2 & 4 & 100 & 100 \\
\hline $\begin{array}{l}\text { Motor Vehicle/ } \\
\text { Agr Mech }\end{array}$ & - & 5 & 38 & 31 & 4 & - & 9 & 8 & 48 & 51 & 2 & 5 & 100 & 100 \\
\hline Building & - & 4 & 22 & 43 & - & - & 2 & 8 & 74 & 41 & 2 & 2 & 100 & 100 \\
\hline Totals & 4 & 8 & 28 & 33 & 2 & - & 6 & 11 & 58 & 43 & 2 & 4 & 100 & 100 \\
\hline
\end{tabular}


future: primary? secondary? university? nonformal education? That this is a question of great relevance to the efficient use of resources and public funds is illustrated by the following contrasts in recurrent costs per student, contained in Table LIV.

\section{TABLE LIV}

ESTIMATES OF UNIT RECURRENT COSTS OF FORMAL EDUCATION 1975-76 (Kt)

\begin{tabular}{lccc} 
Educational Level & Per Year & Per Graduate \\
\cline { 2 - 2 } Primary (rural) & 16 & 130 \\
Secondary aided Form IV & 80 & 450 \\
Secondary tech Form IV & 150 & 750 \\
Secondary aided Form VI & 120 & 700 \\
University (undergrad) & 1,500 & 5,500
\end{tabular}

NOTE: These are costs to government, i.e., excluding expenditures financed by fees and other parental contributions.

Cost per graduate $=$ total from time of entry into primary school.

Secondary costs are an average for day and board pupils.

Source: (KG: 15)

As can be seen, current cost per student in a technical school is almost double that of the first four years of secondary academic school; and any route to further training which involves four years of technical rather than of academic secondary schooling costs KL300 more per graduate. The government's own estimate for 1978-79 confirms the NCEOP's previous estimation (as shown in Table LIV , above). Estimated recurrent cost per student in 1978-79 
ranged from $\mathrm{K} t \mathrm{l} 8$ in a primary school to $\mathrm{K} t \mathrm{l}, 700$ at the University of Nairbbi. The cost to the government for one year of secondary schooling in an aided institution amounts to nearly five times the expense of educating a primary school pupil, while the average cost per student at the University of Nairobi is nearly 100 times the cost per student in a primary school. The estimated recurrent cost per student rose in all types of institutions between 1976-77 and 1978-79, with the University of Nairobi registering the smaller proportion increase per student, while Kenyatta University College recorded the largest increase. An examination of these figures underscores the problem confronting the government in financing continued expansion of the educational system (see, for example, Table LV). Even relatively modest rises in cost per student, such as the $12.5 \%$ increase in per pupil expenditures in primary schools, when combined with large-scale growth in enrollments, require considerable increases in the educational budget.

TABLE LV

ESTIMATED RECURRENT COST PER STUDENT BY TYPE OF INSTITUTION, 1978-79 (Kt)

Educational Level

Primary School

Secondary Aided School

Primary Teacher Training College

Harambee Institute of Technology

Kenya Science Teacher's College

Kenyatta University College

University of Nairobi

\begin{tabular}{|c|c|}
\hline Per Year & Per Graduate \\
\hline $\begin{array}{r}18 \\
85 \\
270 \\
150 \\
902 \\
1,730 \\
1,780\end{array}$ & $\begin{array}{r}145 \\
425 \\
810 \\
900 \\
2,700 \\
6,920 \\
7,720\end{array}$ \\
\hline
\end{tabular}

Source: (KG6, 1979: 180) 
The village polytechnics and the technical and industrial training schools are important initiatives, but as conceived at present, they clearly reflect the unfortunate dichotomy which has grown between formal and nonformal education. As long as the formal educational system operates as it does with its close ties to the examination-selection system, attempts to gain popularity for a separate, nonformal system of education without such ties will have little impact. As in the colonial period, Africans consider vocational education as inferior education, and they regard all government efforts to instill vocational education as attempts to suppress particular ethnic groups, thus restricting their access to formal employment opportunities in the modern sector. The attempt to formalize and ritualize technical and vocational types of education and training attests to the failure of the government to diversify into other areas of the economy where most of the potential for employment actually lies: small scale farming and the social infrastructure at the local level (GR69: 239; GRTO7).

While a reassessment of the value of formal education for an essentially agrarian society is badly needed, advocates in favor of nonformal education have missed the point (GR3; GR37). Their argument provides policymakers with little in the way of realistic policy options with respect to education for rural development. The reasons for this are as follows:

- The topic of "education for rural development" cannot be addressed without linking the various alternatives for rural education 
to the larger issue of the kind of development which will be enhanced by the choice of policy. There are clear linkages between the chosen educational strategy and its impact on the lives and options of the school leavers and their communities.

- Advocating for an expansion of vocational and technical education without addressing the existing disparities in educational resources and opportunities (which created the problem in the first place) seems hollow. Any nonformal educational program which leads to an essentially dual system will ultimately work to reinforce the status quo and thus will neither provide mobility for the school leavers nor promote their interests and the interests of the society at iarge. The lesson from this and other similar examples is clear: any system which contains dual educational institutions will be seen as prejudicial to the groups whose access is 1 imited to the lower status leve1.

\section{GOVERNMENT INTERVENTION IN THE LABOR MARKET}

In addition to vocationalizing the school curriculum, the government of Kenya has, from time to time, tried to alleviate the unemployment problem by direct intervention in the labor market. The policies adopted include the establishment of wage guidelines, land settlement projects, road building projects, and the Africanization of jobs and commerce formerly held by expatriates. Many of the measures taken were of an emergency, short term nature, induced by the pressure of events. Among measures of a short term nature were the three Tripartite Agreements (1964, 1970, and 1979) where the government and 
the employers undertook to increase their labor force by $15 \%$ and $10 \%$, respectively. A review of these agreements indicate that they failed to achieve what they were designed to do.

Quantitatively, by far the greatest contribution to the relief of unemployment was made by the settlements projects. By the middle of 1968, 45,000 families had been settled under various types of the settlement program, which collectively provided gainful employment to nearly 135,000 persons. Several thousands more were employed on individual and corporate farms seasonally as migrant workers (GR69: 91 ).

Measures to step up the Africanization of commerce and industry was justified in part on the grounds tinat it would provide jobs for the local unemployed. The Trading and Licensing Act of 1900 (Regulation 10(1) of Immigration Regulations of 1968) was one such measure designed to restrict Asians from certain economic activities, thus allowing Africans to participate in activities which were previously off-limits to them (GR69: 93). In a similar move, the government ordered all companies in the country to provide full employment returns (Daily Nation, January 17, 1982). According to the Principal Immigration Officer, the purpose of requiring the returns was to ensure that "noncitizens holding jobs which Kenyans were capable of doing were replaced" (Baily Nation).

Most of the other measures taken to relieve unemployment have been directed at the problem of school leavers. They are largely of an experimental nature and have been relatively insignificant quantitatively. A good example is the Village Polytechnic movement, 
which was fully discussed earlier in this chapter. Its quantitative importance to the solution of the unemployment problem has been relatively insignificant.

The best known program directed at the problem of school leavers is the National Youth Service, which was established in 1964 to provide training and employment through work on development projects. Since its inception, a total of 20,000 young Kenyans $(18,452$ men and 1,579 women) have undergone training under this plan. Even so, only one of every fifty applicants is admitted into the program. Until 1972, the policies adopted to stimulate wage employment in Kenya were of an ad hoc, short term nature, often induced by the pressure of events. Since the visit of the ILO Mission to Kenya in 1972 and subsequent publication of the Basic Needs Strategies in 1977 , a more coherent strategy for employment creation has been evolved for the future. The three main elements of this strategy, as indicated in the latest development plan, are a significant acceleration in the rate of growth output (almost a repeat of past policies), a comprehesive incomes policy, and an intensified program of integrated rural development. Nevertheless, past Kenyan experience with regard to implementation suggests that what is preached is not necessarily what is practiced. It remains to be seen whether such strategies will be implemented in the future. The following, Table LVI, surmarizes the employment policies and the institutional framework undertaken to stimulate wage employment in Kenya. 
TABLE LVI

SUMMARY OF EMPLOYMENT POLICIES AND INSTRUMENTS

_Empl Category

Modern Sector

Small Scale Agricul ture

Pastoralists

Rural Non-farm

Urban Informal Sector
Objectives

Alter relative cost of labor Produce appropriate manpower in sufficient numbers

Raise income levels

Increase labor productivity

Raise income levels

Increase livestock numbers \& quality

Increase productivity

Increase labor absorption

Produce some of the privately consumed

basic needs goods

Generate more employment

Produce goods and services for low income groups

Increase productivity

Produce skilled workers
Policy Instruments and Institutional Framework

Wages Policy

Trade Policy

Fiscal Policy

Education and Training Policies

Kenyanization Policies

Pricing Policy

Employment Services

Agricultural Intensification

Agricultural Extension Services \& Training

Rural Development Policy

Rural Developm

Pricing \& Marketing Policies

Provision of basic needs

Pricing and Marketing Policies

Development of arid \& semi-arid areas

Provision of basic needs

Rural Development Policy

Appropriate training, e.g. the Village

Polytechnics

Review of the existing legislation on rural

non-farm activities and renove or anend those

sections that are unnecessarily inhibitive

Provide credit extension services \& other support

Remove restriction on informal sector activities

Provide basic infrastructure including the

necessary support services 
EMPLOYMENT CREATION BY TRIPARTITE AGREEMENT

In addition to efforts to create employment in Kenya through expansion of the economy with the help of foreign capital, the Kenyan government has attempted from time to time to produce employment artificialiy, but directly, through agreements with the Employers Federation and the Trade Unions. Since 1963, there have been three such agreements, one in 1964, the second in 1970, and the third in 1978. These were recognized to be short term measures to allow time for long term measures to take effect. These efforts are worthy of specific mention, particularly the 1970 and 1979 agreements.

The 1964 Tripartite Agreement

The aim of the 1964 Agreement was

to alleviate the hardships being experienced by the unemployed and to provide the new government with a breathing space in which to get its plans for economic development under way.

The government undertook to expand employment by $15 \%$, and the employers' goal was $10 \%$. In a conciliatory move, the trade unions agreed to a policy of wage standstills for one year. Stewart (GR146) explains that the conjunction of events in which the 1964 Agreement took place was significantly different from the 1970 and 1979 Agreements. In the first place, the 1964 Agreement occurred at a time when employment had been falling steadily and substantialiy: by 83,000 or $13 \%$ between 1960 and 1963. Secondly, it occurred just a year after independence when it was particularly important for the government to reassure its own people and the capitalist world that 
it was in command of events. Stewart explained the situation this way:

One of the key elements behind the 1964 Agreement was the determination to show people overseas, particularly foreign investors, the spirit of cooperation that united employers, workers, and Government, and that was symbolized in the Tripartite Agreement.

(GR146: 177)

Indeed, some of the loss in employment was due to a lack of confidence by the resident foreign community and foreign private capital abroad, so that, insofar as the Agreement generated confidence, it contributed both to its own and other more significant objectives.

The 1964 Agreement was greeted with enormous and immediate response; within two weeks, 205,000 workers had registered, of whom 106,000 were classified as top priority (i.e., locally domiciled unemployed--ex-wage earners and the landless). Despite the claims that over 38,000 extra workers were absorbed under the plan, total employment increased by only about 18,000. Some of the extra jobs came from the transforming of casual into regular employment. Among men, the proportion of casual employment fell from $7.5 \%$ to $6 \%$ between 1963 and 1964 (GR146: 178). There was also a substitution of adult for child labor, with an absolute drop in child labor of 3,000 for the same period. It is, therefore, difficult to tell whether the Agreement had any long-lasting effect on employment. Employment in private industry and commerce was the same in 1965 and 1964. Vacancies registered in 1965 were more than $20 \%$ lower than in 1963, while applications for employment were $12 \%$ higher and placements about 10\% lower. These figures suggest that the Agreement had only a 
temporary effect. In addition, the Agreement did not bring the industrial peace that was originally envisioned. In 1964 and 1965, there were a total of 494 strikes involving 172,757 employees (KG8).

\section{The 1970 Tripartite Agreement}

The aim of the 1970 Agreement was similar to that of the 1964 Agreement: to alleviate unemployment. The agreement contained three main elements:

- the government and employers agreed to expand their employment by $10 \%$ of their regular establishment;

- employees agreed to a twelve-month wage standstill;

- there were to be no strikes or lockouts during the Agreement. Interestingly, employers were given the option, in special cases, of making a financial contribution to national projects instead of expanding employment.

A1together, 290,111 people registered $(46.4 \%$ of total modern sector employment in 1969 (see Table LVII), this figure cannot be taken as a true measure of unemployment because people with jobs of one kind or another also registered. However, the massive response does give a clear indication of the enormous potential demand for modern sector employment.

Table LVIII shows the ratio of registrations to employment. There were considerable variations. Nairobi had the lowest ratio where registrations formed slightly less than one third of existing employment. Registrations were greatest in relation to existing employment wherever employment formed a relatively small proportion of the 
TABLE LVII

REGISTRATION UNDER TRIPARTITE AGREEIAENT

(DECEMBER 1970)

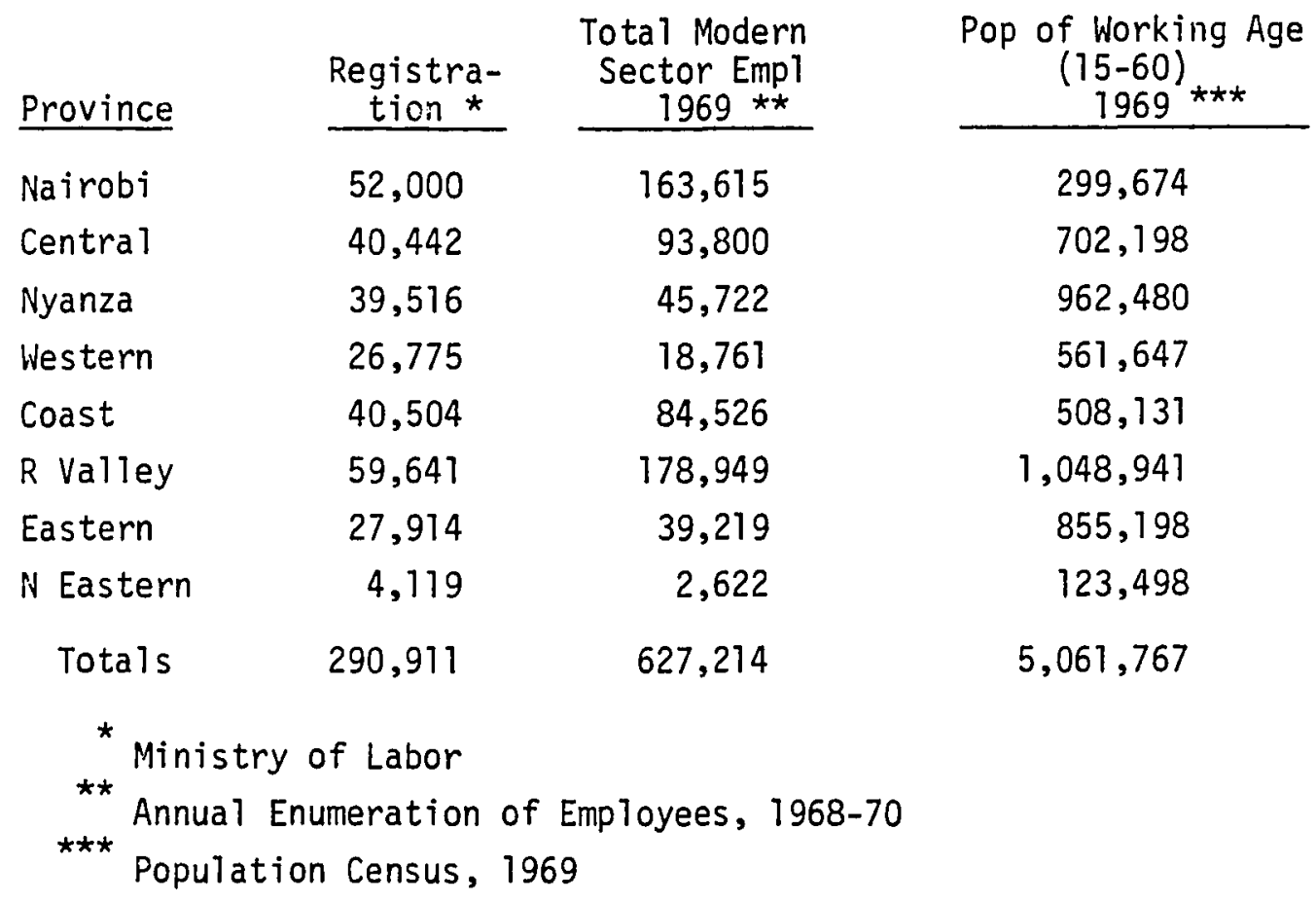

Source: (GR146: 157)

total population of working age. In both the Western and North Eastern Provinces, modern sector employment covers a very small proportion of the population of working age $(3.3 \%$ and $2.1 \%$, respectively); and these were the only provinces in which registrations exceeded the total number employed. Nyanza and Eastern Provinces, which have the next smallest proportion of modern sector employment in relation to population, also showed substantially above-average ratios of registration. The Nairobi figure indicates a positive correlation between registration in relation to working age population and the proportion of the working age population employed in the modern sector. It appears 
that the urban areas attracted a disproportionate share of registration, reflecting the belief that good jobs were more likely to be found in the larger cities.

\section{TABLE LVIII}

\section{REGISTRATIONS AS INDICATORS OF DEMAND FOR EMPLOYMENT}

\begin{tabular}{|c|c|c|c|}
\hline Province & $\begin{array}{l}\text { Regis as \% of } \\
1969 \text { Empl } \\
\text { (modern sector)* }\end{array}$ & $\begin{array}{c}\text { Regis as \% of } \\
\text { Working Age } \\
\text { Pop } \star \star\end{array}$ & $\begin{array}{r}\text { Empl as \% of } \\
\text { Working Age } \\
\text { Pop } \star \star \star \\
\end{array}$ \\
\hline Nairobi & 31.8 & 17.4 & 54.6 \\
\hline Central & 43.1 & 5.8 & 13.4 \\
\hline Nyanza & 86.4 & 4.1 & 4.8 \\
\hline Western & 142.7 & 4.8 & 3.3 \\
\hline Coast & 47.9 & 8.0 & 16.6 \\
\hline R Valley & 33.3 & 4.9 & 17.1 \\
\hline Eastern & 71.2 & 3.8 & 4.6 \\
\hline N Eastern & 137.1 & 3.3 & 2.1 \\
\hline Totals & 46.4 & 5.8 & 12.4 \\
\hline $\begin{array}{r}{ }^{*} M \\
{ }^{* *} \mathrm{~A} \\
{ }_{* * *} \mathrm{P}\end{array}$ & $\begin{array}{l}\text { ry of Labor } \\
\text { Enumeration of } \\
\text { tion Census, } 1969\end{array}$ & loyees, $1968-70$ & \\
\hline
\end{tabular}

Source: (GR146: 159)

Altogether, 45,680 jobs were provided under the plan, 30,203 by the private sector and 15,477 by the public sector. The public sector thus provided jobs for an additional 6.5\% of its 1969 employees, and the private sector provided jobs for $7.8 \%$. The percentage for public and private combined was $7.3 \%$, which falls short of the targeted $10 \%$. Overal1, $16 \%(45,600)$ of those registered $(290,911)$ got 
jobs. This low ratio is significant from the point of view of assessing the effect of the Agreement on aspirations: clearly, it raised more hopes than it satisfied. As shown in Table LIX below, placement was in general only a fraction of registration--less than a fifth in a11 cases except Nairobi and Eastern Province.

TABLE LIX

\section{PLACEMENT UNDER THE TRIPARTITE AGREEMENT} (DECEMBER 1970)

\begin{tabular}{|c|c|c|c|c|}
\hline Province & $\begin{array}{l}\text { Private } \\
\text { Sector }\end{array}$ & Government & $\begin{array}{c}\text { Government }+ \\
\text { Private } \\
\text { Sector } \\
\end{array}$ & $\begin{array}{r}\text { Placement } \\
\text { as \% } \\
\text { Registrations } \\
\end{array}$ \\
\hline Na irobi & 8,146 & - & 8,146 & 15.7 \\
\hline Central & 6,053 & $555^{\star}$ & $6,608^{\star}$ & 15.0 \\
\hline Nyanza & 1,162 & 1,142 & 2,304 & 2.9 \\
\hline Western & 882 & 102 & 985 & 3.3 \\
\hline Coast & 4,262 & 159 & 4,421 & 10.5 \\
\hline R Valley & 8,624 & 1,055 & 9,679 & 14.5 \\
\hline Eastern & 957 & - & 957 & 3.6 \\
\hline$N$ Eastern & 116 & - & 116 & 2.8 \\
\hline Totals & 30,203 & 15,477 & 45,680 & 10.4 \\
\hline \multicolumn{5}{|c|}{ Source: (Tables LVII and } \\
\hline
\end{tabular}

The 1979 Tripartite Agreement

On December 12, 1978, the fifteenth anniversary of Independence, the President announced that a third Tripartite Agreement had been concluded whereby wage employment in both private and public sectors should be increased by $10 \%$, effective January 1 , 1979. By June 30, 1979, a total of 260,089 people had registered as unemployed $(64,000$, 
TABLE LX

REGISTERED JOB SEEKERS AGAINST DECLARED VACANCIES

$(6 / 30 / 79)$

\begin{tabular}{|c|c|c|c|c|c|c|}
\hline \multirow[b]{2}{*}{ Category } & \multirow{2}{*}{$\begin{array}{c}\# \text { of } \\
\text { registered } \\
\text { job } \\
\text { Seekers } \\
\end{array}$} & \multicolumn{4}{|c|}{ Declared Vacancies } & \multirow{2}{*}{$\begin{array}{c}\text { Excess of } \\
\text { Seekers } \\
\text { Over } \\
\text { Vacancies } \\
\end{array}$} \\
\hline & & Private & $\begin{array}{l}\text { Central } \\
\text { Gov't }\end{array}$ & $\begin{array}{l}\text { Public } \\
\text { Local } \\
\text { Gov't }\end{array}$ & Total & \\
\hline Technical & 3,572 & 1,072 & 8,309 & 802 & 10,183 & $(6,611)$ \\
\hline Managerial & 749 & 438 & - & 39 & 527 & 222 \\
\hline Clerical & 14,264 & 2,301 & 5,004 & 712 & 8,017 & 6,247 \\
\hline Sales & 3,170 & 462 & - & 38 & 500 & 2,670 \\
\hline Services & 14,046 & 1,254 & 2,727 & 310 & 4,291 & 9,755 \\
\hline Skilled & 17,981 & 3,409 & 747 & 1,651 & 5,807 & 12,174 \\
\hline Semiskilled & 16,607 & 3,295 & 3,789 & 644 & 7,748 & 8,859 \\
\hline Genrl Labor & 108,614 & 15,658 & 5,174 & 2,023 & 22,855 & 85,759 \\
\hline School Leaver & 81,086 & - & - & - & - & 81,086 \\
\hline Totals & 260,089 & 27,889 & 27,750 & 6,289 & 59,928 & 200,161 \\
\hline
\end{tabular}

Sources: (GR70: 9.2 (Table 9.1) 
or $24.6 \%$ of whom were female) which is equivalent to $28.5 \%$ of the formal sector of wage employment in 1978. The number registering was not far short of the 290,911 who responded to the 1970 exercise.

One interesting revelation is that the number of declared vacancies in the professional and technical category is well in excess of the numbers of registered job seekers (see Table $L X$ ). In terms of numbers, unskilled general labor and agricultural workers (42\%) and school leavers (31\%) dominate; together they accounted for $73 \%$ of job seekers in 1979. Altogether, a total of 71,515 (27.5\%) of the registered seekser found jobs in the public sector, compared with only $16 \%$ in 1970. A total of 11,587 jobs were found in addition to the 59,928 declared vacancies at the time. In comparison with the 1970 Agreement, the 1979 Agreement demonstrated improved performance of the public sector, which provided jobs for an additional $3.8 \%$ of its 1978 employees. On the other hand, private sector employment decreased from $7.8 \%$ in 1970 to $7.1 \%$ in 1979 . The percentage for public and private combined was $7.9 \%$, which was short of the targeted $10 \%$ (see Table LXI).

There is reason to believe that the $7.9 \%$ increase might have been exaggerated. In the first place, average annual rate of growth in the formal sector wage employment over the five year period 19731978 was $3.7 \%$; this trend might have continued independent of the Agreement. Secondly, past trends in local government recruitment suggest normal growth of $2 \%$, leaving no more than $5 \%$ attributable to the Agreement. Given these circumstances, Livingstone (GR107) concluded that an upper limit of 18,274 jobs might be attributable 
to obligations imposed under this agreement, which represents only $2 \%$ of the total modern sector employment in 1978 and oniy $25 \%$ of th 72,000 jobs considered by the ilinisiry of Labor to have been created. Therefore, the real effect of the agreement is distorted.

TABLE LXI

SUMMARY OF THE EMPLOYMENT TREND: THE 1970 AND 1979 TRIPARTITE AGREEMENTS

\begin{tabular}{|c|c|c|c|c|c|}
\hline Sector & $\begin{array}{l}\text { Placement } \\
1970 \\
\end{array}$ & $\begin{array}{c}\% \text { Increase } \\
\text { in Emp } 1 \\
1969 \\
\end{array}$ & $\begin{array}{l}1978 \\
\text { Wage } \\
\text { Empl }\end{array}$ & $\begin{array}{l}\text { Increase } \\
\text { in Emp } 1 \\
6 / 30 / 79 \\
\end{array}$ & $\begin{array}{c}\% \text { Increase } \\
\text { in Empl } \\
6 / 30 / 79 \\
\end{array}$ \\
\hline Public & 15,477 & 6.5 & 390,000 & 34,226 & 8.8 \\
\hline Private & 30,203 & 7.8 & 521,600 & 37,289 & 7.1 \\
\hline Totals & 45,680 & 7.3 & 911,600 & 71,515 & 7.8 \\
\hline
\end{tabular}

Source: (GRT07)

There are also other reasons which minimize the real employment contribution of these Agreements. First, a certain number of vacancies occur naturaliy during the year through labor turnover. Data from a study of labor turnover showed a rate of turnover of $27 \%$ for the economy as a whole (GR71). The figures for agriculture were over $60 \%$, while mining and construction together accounted for $40 \%$. Outside these industries, the rate varied between 10 and $12 \%$. A rate of $10 \%$ means that $10 \%$ of the jobs in a typical firm become vacant during each year without any expansion in the number of employees. Thus, with such rates, the obligations under the Tripartite Agreement could be met by filling the vacancies which occurred during the year. There are also allegations that employers normally fire 
newly hired workers after the agreement period is over.

From the perspective of alleviating poverty and generating productive income-earning opportunties, the type of jobs created do not constitute employment in the true sense of the word. For example, in the 1979 Agreement, $80 \%$ of private sector and $22 \%$ of public sector jobs were general labor, and overall general labor was 55\%. If general and semiskilled labor were taken together, these percentages would be $87 \%, 22 \%$, and $62 \%$, respectively. Only $8 \%$ of private sector employment is clerical, compared with $50 \%$ for the public sector, and $25 \%$ overa 11. On the basis of the data presented above, it is obvious that the economic and employment effects of the Tripartite Agreements were extremely limited. The Agreements probably contributed more to raising expectations than to realizing them, as shown by the massive registrations.

It is, therefore, reasonable to conclude that the problem of educated unemployment does not lie so much in the numbers of school graduates as it does in the whole philosophy of the educational system which mentally prepares the pupils for nonexistent high paying urban jobs in the context of a dependent economy. In the forseeable future, this will continue to be the case unless there are fundamental changes both inside the school systems and outside them.

\section{SUMMARY}

The school leaver problem in Kenya is more complex than is often assumed. It is an oversimplification to consider it essentially as an excess of new school leavers over new job openings. The root 
of the problem lies in the interaction of the conventional educational system and the wage and salary structure through the allocation of jobs and wages by reference primarily to educational qualifications. This has led to a great desire for higher education and for migration to major urban centers.

As shown previously, many of the efforts to solve the unemployment problem have taken place within the school system, with occasional governmental intervention in the labor market, through tripartite agreements and the setting of wage guidelines by the Industrial Court. The evidence presented in this study indicates that many of these educational reforms solved an immediate political problem by offering a new outlet for the economic aspirations in the society. But their impact on employment creation has been limited by the restricted market for technical and vocational skills. The move to employ more school leavers through tripartite agreements among the government, employers union, and trade unions has also turned out to be temporary and to provide only limited solutions.

What can be observed in Kenya (and in Africa in general) is that the initial concern and emphasis on manpower development through the expansion of the educational system was modified to deal with the unemployment of graduates which the modern sector could not cope with. The aim of this policy was to inculcate values, attitudes, knowledge, and skills which would lead school graduates to be comitted to opportunities in the rural areas. In fact, there are striking similarities between this policy and the colonial policy which emphasized vocational education for Africans. In essence, the educational system in 
postindependent Kenya has become the pillar of neocolonialism. 


\title{
CHAPTER V
}

\author{
ANALYSIS AND CONCLUSIONS
}

The purpose of this research project has been to examine the consequences of Kenya's educational and economic growth policies on the problem of urban unemployment. Central to the urban unemployment protlem has been the dichotomy arising out of a rapidly growing number of school graduates on the one hand, and on the other, the limited growth in employment opportunities for this segment of the labor force. Thus, an attempt to trace the causes of this particular developmental dilemma must place the problem in the wider context of the economic, political, and social predicament with which Kenya is confronted.

The approach to this study has basically been in the political economy tradition: seeking to explain the interactions among social, political, and economic organizations and processes. A dependency approach is used to analyze the structuring of the post-independence Kenyan society, focusing first on the historical pattern of Kenyan incorporation into the international economy, second on the shaping of Kenyan social relations as the country's links with the international economy changed in the context of decolonization, and third on the postindependence structure of the Kenyan economy as shaped by dependence on external economies. As shown in the previous chapters, these processes of change led to some structural economic change and much 
institutional continuity in the post-independence period. The central focus of this study has been, therefore, to determine to what extent dependency conditions the relationship between the educational system and the economy and distorts manpower planning in Kenya.

THE COLONIAL LEGACY AND THE IDEOLOGY OF DEVELOPMENT

To understand the causes of underdevelopment and growing unemployment in Kenya, a historical perspective must be examined, particularly the periods of colonial and post-colonial development.

Unti1 the mid-1950's, the structure of the Kenyan economy, educational system, and social interaction reflected the dominant interest of the tiny European settler class which limited effectively the political activity and social mobility of the Africans. This European dominance was maintained by restrictive legislation developed in the periods between 1902 and 1952 and reflected the ideological climate of colonial rule which justified the permanent relegation of Africans to the status of 1aborers (GR22; GR105; GR168).

The measures introduced to forestall or permanently prevent African participation in Kenya's political economy included: (a) eviction of Africans from the White Highland and relocation in the Reserves; (b) the forcing of a large percentage of the African population to work in European farms; (c) the barring of Africans from individual ownership of land; (d) the unequal distribution of tax burden; (e) the denial of Africans' right to grow cash crops; and (f) severe credit restrictions. By manipulating the legal frameworks of colonial rule, the European settlers in Kenya constructed a system of Apartheid capitalism for their 
own exclusive benefit (GRI17).

On the eve of independence, the Kenyan economy was already structured along lines which could effeciently sustain very different levels and styles of living for a tiny minority of Europeans on the top and the impoverished African population on the bottom. Large sectors of the civil service as well as the private sector, including manufacturing and agriculture, were still controlled by expatriates. Access to both education and income was heavily racially biased and self-enforcing, as poor educational qualifications justified limited African access to higher paid jobs and low incomes increased the difficulties of acquiring an education. Some of these imbalances still persist and may even have been accentuated by the developmental policies of the post-independent government.

\section{"REFORM" OR REVOLUTION?--THE INDEPENDENCE BARGAIN}

The sharp inequalities among the three racial groups, in particular the limited amount of land available for Africans residing in the Reserves and the large land holding of the Europeans, became a major catalyst for the Mau Mau uprising in the early 1950's. The rise of African nationalism in this period succeeded in creating a new political context in which successive colonial Secretaries accepted the urgent need for political and economic reforms in the African areas.

The most important reform was the 1954 Swynnerton Plan, which introduced some changes into African agriculture. The Plan included the development of extension service in the African areas, permission to grow cash crops, access to credit, and land consolidation and 
registration. In other words, the racial division of labor which was strongly emphasized in the early colonial period ceased to be important as the post-colonial economy took shape in the 1960's. But the declared aim of this process was to encourage the emergence of an African capitalist class with interest in land, commerce, and political stability. This class assured the smooth transition of Kenya from colonialism to neocolonialism. The important question of structural transformation for the majority of Kenyans who had formed the most potent Mau Mau base was largely forgotten.

The 1950's and 1960's thus marked a period when the racial character of the society was dismantled, and the Africans increasingly participated in the economic and political affairs of Kenya. Important though these changes were, the underlying philosophy concerning economic development since independence has remained unchanged. This philosophy stresses that growth, whether for Europeans or for Africans, can be sustained only by relying on skills, capital, and enterprises imported from the developed countries of the West. The new leadership, under the chairmanship of Jomo Kenyatta, was, from the outset, fully committed to the maintenance of the economic structure inherited from the colonial period, thereby insuring the continuity of colonial economic relations in Kenya. This is clearly evident from the President's speech to Parliament:

My government has continually affirmed its determination to build a nation based on greater welfare for all its citizens. We believe that rapid economic growth is essential to our goal. . . . Rapid growth requires the cooperation of other countries. We need external assistance both to finance Government development projects and to provide technical advice on managing development. While 
we appreciate the benefits of this dependence, we propose to achieve greater control over our economic destiny by reducing the influence of external factors.

(KG2: i)

The ideological and developmental philosophy which the new leadership emulated called for the maintenance of colonial development plarining and economic relationship. The new leadership viewed such institutional continuities with the West as necessary to its immediate goal of rapid economic growth resulting from increased access to foreign capital, skilled cadres, technology, and markets. Structural transformation of a Socialist type as in the neighboring Tanzania was ruled out. Instead, Africanization of commerce, industry, schools, agriculture, and the civil service became the hallmark of the Kenyan government developmental policy.

Africanization was directed toward establishing broader African participation in the monetary sector. Some land was distributed among the peasants. Part of the White Highland and other areas of the country were converted into settlements where about three quarters of a million families are now settled. About $90 \%$ of the civil service was aiso Africanized by 1967, benefitting mostly those with some education. Through legislation and other administrative directives, non-Kenyans were gradually replaced in the army, in education, and in business. However, despite the increased access to opportunities, certain unanticipated problems emerged which have drastically influenced the nature of politics as well as the pattern of development in the country.

The policy. of Africanization was adopted at the time of independence in order that Africans might take over positions of power and 
privilege from the Europeans and the Asians. This new class of Africans has used its position of power to accumulate personal wealth. As a result, the pyramid of privileges which existed during the colonial period has simply shifted from the Europeans to a small elite group of Africans, and the inequalities may even have been accentuated.

\section{DEPENDENCE, TRANSFORMATION, AND STAGNATION}

At independence in 1963, Kenya inherited a disintegrated economic system, already organized for effective maintenance of different social strata. The economy, the educational system, the public service system, and agriculture were all organized around the interests of the Europeans. This legacy of colonial rule left the new leadership with limited options to chart the course of national development independently. To resolve this unsetting situation, Kenya sought to maintain close ties with the major Western industrial nations in order to build overseas markets for its products, to expand tourism, and to maintain the flow of private and public foreign investment into the country. The Foreign Investment Protection Act of 1964 (KG18) signifies the importance the government attaches to external economic assistance in its development drive.

The detailed evidence of national economic indicators examined in this study, however, leads to the conclusion that Kenya's reliance on external economic assistance has reduced its ability to determine the course of national development independently. Some of the dependency is shown by the openness of the economy. Exports and imports form a high percentage of gross domestic product. The major domestic exports 
of the country consist of plantation-grown crops such as coffee and tea. This is a major weakness from the point of view of achieving economic independence. Because of the dominant position of developed economies in the world market, Kenya is not in a position to bargain effectively for its products to attain comparative advantage. The events of 1975 and 1978, when coffee prices went down and the balanceof payments problem worsened, are good reminders of Kenya's vulnerability in the world market.

The "incentives" guaranteed under the 1964 Foreign Investment Protection Act enhance the process of decapitalization in the form of repatriated profits, interest payments on loans, and royalty fees. This has drastically reduced the amount of resources available to Kenya and has contributed instead to the growing balance-of-payment difficulties. The policy of import-substitution has resulted in reduced employment opportunities, high import dependence, high industrial profits, and a high industrial wage for the labor elite, further aggravating the inequalities in income among both regions and social groups.

Another measure of underdevelopment is the limited range of policy options available to the regime. Government participation in joint venture activities with foreign capital seems to offer relatively little significant constraint on foreign economic powers. Rather, a symbiotic relationship has developed between foreign capital and the State, focused around the structuring of "shared privileges" to the mutual advantage of the multinational sector and of the "insider" African bourgeoisie which dominates the Kenyan State (GR99). Such participation is geared toward bringing about a broader base of local 
private control and ownership rather than toward public control of the means of production. The practice also institutionalizes special access for foreign enterprises to obtain such privileges as work permits, exemption from local borrowing restrictions and import licenses, etc. The combined effect is to inhibit the full productive use of much of the country's resources and thereby negate long-term, broadiy based growth in the economy.

Kenya's continued reliance on imported technology, spare parts and other processed inputs, low world prices for coffee and tea, and rapidly increasing prices for manufactured goods has contributed to chronic trade and balance-of-payments deficits. The 1977 windfall coffee earnings helped matters for a short time, but the situation again worsened. Kenya's deficit for 1976-77 was just over Kt40 million and improved to Kt34 million in 1977-78. However, in 1978-79, the situation worsened by three times, and the deficit reached almost Kt 100 million. Provisional figures for $1979-80$ show the deficit at Kt88 million (The Standard, Oct 11, 1981: 5). The estimate for 1980-81 is almost K!173.4 million (KG6. 1981). This is a massive increase--almost 333\% in 5 vrs. To offset these deficits, Kenya has continued to borrow large sums of money from bilateral and multilateral agencies. Unfortunately, debt servicing charges for these loans has merely increased the deficits. As a result, Kenya has mortgaged itself to the West, and its ability to make truly independent decisions has been circumscribed. The removal of these constraints would require not just marginal changes in policy and trade relations, but also profound structural adjustments, both internally and externally. 
CONTINUITY AND CHANGE IN EDUCATIONAL POLICY

In the field of education, two achievements are noticeable in the post-independence period. First, the racial character of the school system which was strongly emphasized in the colonial period was abolished after independence. The integration of the different school systems, however, was not followed by fundamental changes in the structure of the educational system as a whole. The policy of Africanization simply transformed the racial structure of the colonial society into a classstructured, post-indepencence society.

The second significant development that took place was the rapid quantitative expansion of enrollments at all levels of the educational system. This uncontrolled expansion without any attempt to significantiy alter the colonially-molded school system contains a number of inherent contradictions from the main thrust of development: regional educational disparities, rising costs, and educated unempioyment.

The Problem of Equity

The educational system in Kenya is characterized by an enromous disparity between rural and urban educational systems and among highcost and low-cost schools in the urban areas. The disparities documented in this study had their roots in the colonial past. Until independence, the extent of educational opportunity for Africans correlated closely with the intensity of mission activity. Those tribal groups, such as the Kikuyu and the Luo, whose geographical accessibility made them the first target of mission education, received greater educational inputs than those who were not. Proximity to European areas, and above 
a11, proximity to Nairobi yielded advantages for employment and for: exposure to new patterns in economic relations. After independence, these two groups, particularly the Kikuyu, were able to move most rapidly into open educational slots and into new economic opportunities availed to Africans. Unfortunately, this has not been the case for those Kenyans who live in the most underdeveloped regions of the North Eastern, Coast, and some parts of the Rift Valley Provinces.

The effort to achieve a wider distribution of educational opportunities by accelerating the rate of expansion in the post-independence period has, in fact, accentuated the disparities inherited from the colonial period. The inequalities are further aggravated by differences in the quality of teachers, educational facilities, and other inputs among schools serving different geographical areas and income groups. Those provinces and districts that were closely integrated into the colonial economy had a head start in Western education; and because of their political and economic influence, they have consolidated their lead in the post-independence period. One such region is Central Province, home of the kikuyus, who are now in control of the political and economic apparatuses of the government. What clearly emerges from this study is that educational and other benefits in Kenya are being distributed in favor of the economically and politically advantaged districts and provinces in the country.

The uneven development of educational opportunities among the various ethnic groups in Kenya poses something of a dilemma in civil service staffing: should criteria be employed for the sake of national harmony, or should universal achievement norms be adhered to for the 
sake of professionalism and civil service efficiency? Because the political culture and development have not wholly embraced a smoothly managed merit and achievement system in the administrative process, a certain amount of tempered patronage is present. As a result, ethnic differences are well pronounced (GR122). Allegations of Kikuyu predominance in the Kenyan political economy are widespread.

The constant expansion of formal education in Kenya is necessary to preserve the impression of widening opportunity under the leadership of Kenyatta and his Kikuyu-dominated cabinet. But clearly, there is a limit to the extent to which Kenya can absorb the cost of continuing at the present rate of expansion. The government spends approximately $32 \%$ of the total national budget on education, and dire predictions have been made about other forms of productive investment likely to be hampered by a continuation of the present rate of growth in educational expenditure. It is clear that there will be a slowing down in this rate, but the danger is that such an action will make the government appear to be blocking the aspirations of those Kenyans who had seen education as their salvation.

Recruitment

Within the context of its strategy of development, Kenya's system of education has continued to offer opportunity for advancement through a competitive examination system and to hold out to young people the prospect of reward through merit and hard work (GR38; GR144). Credentialism is well ingrained in the political culture, and the governmental manpower policy seems to perpetuate it. David Court 
challenges the basis of this policy and concludes:

The preoccupation with educational qualification as the touchstone of educational merit may be attacked on the educational grounds that examination results are a relatively poor predictor of employment performance--but it has a strong socio-economic rationale. In a pluralistic society characterized by inequalities, it provides visible evidence against the charge of official discrimination. Poor people can accept ultimate inequalities of wealth if they believe that they have a chance to enter the school system, will be judged by objective criteria within it, and will have an equal chance to enter employment outside it.

(GR38:682)

As a result, the concept of equality of opportunity is invoked as a means of achieving the political stability necessary to preserve a selective school system geared to the high-level manpower requirements believed to be necessary for economic growth. In this respect, it is reasonable to conclude that the manpower requirements of particular industries have continued to dictate the content and structure of the educational system in Kenya. Given the likely continuation of disparities of educational provision by region, the credibility of a policy of equal opportunity depends upon the impartial use of examination criteria for allocating opportunities.

For many students, secondary school is the single target of their aspirations. In fact, many repeat once or twice in Standard 7 in order to pass the entrance examination. This is understandable in view of the fact that it is from secondary school that other viable openings in life (e.g., teacher training, employment in commerce, recruitment to the Armed Forces, etc) become real possibilities. However, because of the limited capacity of the government to meet the growing demand 
for education, competition for secondary school entrance has been intensified. Since very few students can be admitted to this level, the unrestrained expansion of Harambee secondary schools, which are below recognized standards, has occurred; these schools provide education for $60 \%$ of the Kenyan secondary school students. The implication is that a high proportion of the nation's secondary school students are being trained in low quality schools, and their ability to compete in national examinations and employment is very limited. A tracer project by Kinyanjui (GR 88 ) found that $37 \%$ of Harambee secondary school graduates are unemployed, compared with $9 \%$ of the graduates of government secondary schools. Kinyanjui also found that while $63 \%$ of the pupils in government-aided schools obtained Division III certificates and above in 1969 and 1970, over 70\% of Harambee school leavers either failed or obtained passes which merited only the East African Certificate of Education during that same period. This pattern has not changed since 1970 (see Table XXXXII, Chapter IV).

The expansion of the Harambee schools immediately after independence served certain social, economic, and political objectives in the country. For the government, the Harambee schools served as a safety valve to accommodate the growing demand for education. The financial burden on the government was also removed. For the majority of Kenyans whose aspirations were raised, the Harambee schools provided an impression of expanded opportunities resulting from political independence. But in actuality, Harambee school graduates have received very little notice. On the other hand, children from upper class backgrounds who study in high-cost schools, perform very well in examinations and 
are allowed to occupy high power positions in the modern sector of the economy. In short, the different school systems in Kenya have different resultant social impacts.

THE EDUCATION-EMPLOYMENT DILEMMA: CONCLUDING REMARKS

The unemployment among school leavers in Kenya has been viewed as entirely an educational problem, and all efforts to solve it have been directed toward improving the different components of the school system, such as examinations and curriculum. There are two reasons for the focusing of attention on the school system. First, the government rationalized the problem to be a matter of graduates lacking marketable skills to enter the work force (PI3, 4, 5). This led to a concerted effort to establish village polytechnics and secondary technical schools. These educational reforms solved an immediate political problem by offering a new outlet for the economic aspirations in the society. But their impact on the employment prospects is severely limited by the restricted market for technical and vocational skills in Kenya.

The second reason the government has continued to tinker with the educational system stems from the fact that education is the only area where the government has any direct control over policy matters. The distribution of educational resources and opportunties, the content of educational curricula and the examination, are determined by established national governmental agencies, with some private participation (PI 4 ). The economic sphere, on the other hand, is beyond the control of the Kenyan government. The separation of economic decisionmaking 
from the political arena allows external economic actors to dominate economic policy. So long as the benefits generated by the multinational sector are shared with a few elite Africans, national control of economic decisions is not vigorously sought. The result has been that the efforts to reform the educational system in the absence of economic reform simply did not lead to a resolution of the unemployment problem. The move to employ more school leavers through tripartite agreements between the government, employers, and trade unions also turned out to be a temporary and limited solution.

The challenge of education for rural development cannot be solved by good intentions. While a reassessment of the value of formal education for an essentially agrarian society such as Kenya is badly needed, advocates in favor of vocational training have missed the point. Hanson explains the shortcomings of current rural educational strategies:

No matter how imaginative a plan for rural education may by, it cannot by itself achieve its goals if there is no comprehensive strategy for rural development. Such a rural development strategy must be accorded more than verbal alleigance; it must be allocated the resources necessary to carry it out, be dedicated to ensuring that rural incomes approach those in urban areas, and be implemented not to realize social class interests but rather to improve the quality of life of the entire rural populace. Only such a comprehensive strategy and the policies and programs undertaken to implement it will provide the conditions under which young people will be able to visualize and then achieve the good life on the land or in the village.

(GR60: 80)

The results of this study suggest that changes in the educational structure alone are insufficient to bring about employment in the labor market. Although education does effect major changes in society in the long run, schools are in the short run largely dependent variables of 
the society that surrounds them. Any attempt to formalize and ritualize vocational education without a significant change in the economic structure of Kenya will have little impact on employment. It would be foolish to expect of schools that which they cannot alone provide. Therefore, the unemployment problem is rooted in the structure of the Kenyan society, and particularly in the failure of the Kenyan economy to industrialize and modernize at a rate that absorbs the entire labor force, including the school leavers. The unemployment existing among school leavers in Kenya is, then, a reflection of the contradictions and Timitations existing in the economic sector of the country. If this essentially economic problem is to be resolved, it appears that the solution must come about through structural adjustments of the entire political economy of Kenya, both internally and externally. 
GENERAL REFERENCES

1. Abernathy, David D. The Political Dilemma of Popular Education: An African Case. Stanford: Stanford University Press, 1969.

2. Adelman, Irma and Cynthia Taft Morris. Economic Growth and Social Equity in Developing Countries. Stanford: Stanford University Press, 1973.

3. Ahmed, Manzoor and Philip Coombs. Education for Rural Development: Case Studies for Planners. New York: Praeger Publishers, 1975.

4. Almond, Gabriel and James Coleman. The Politics of Developing Areas. Princeton: Princeton University Press, 1960.

5. Amin, Samir. Unequal Development. New York: Monthly Review Press, 1976.

6. Accumulation on a World Scale: A Critique of the Theory of Underdevelopment. 2 vols. New York: Monthly Review Press, 1974.

7. Anderson, John E. The Struggle for the School: The Interaction of Missionary, Colonial Government and Vationalist Enterprise in the Development of Formal Education in Kenya. Nairobi: Longmans, 1970 .

8. Primary School Leavers in Rural Areas. Discussion Paper No. 39A, Nairobi: Institute for Development Studies, University of Nairobi, 1966.

9. "Self-Help and Independency: The Political Implications of a Continuing Tradition in African Education in Kenya." African Affairs. LXX, No. 278, January (1971), pp 9-22.

10. The Village Polytechnic Movement. Evaluation Report No. 1, Nairobi: IDS/SRDP Research and Evaluation Unit, Institute for Development Studies, University of Nairobi, 1970.

11. "The Formalization of Non-formal Education, Village Polytechnics and Prevocational Youth Training in Kenya." In Education and Rural Development. Ed. Philip Foster and James R. Sheffield. London: Evans Brothers, Ltd. 1973. pp 283-301.

12. Arrighi, Giovanni and John Saul. Essays on the Political Economy of Africa. New York: Monthly Review Press, 1972. 
13. Baran, Paul. The Political Economy of Growth. New York: Monthly Review Press, 1968.

14. Barnet, Richard and Ronald Muller. Global Reach: The Power of the Multinational Corporations. New York: Simon and Schuster, 1974.

15. Bennett, George. "The Development of Political Organizations in Kenya." Political Studies, 2, June (1957), pp 119-122.

16. Bienen, Henry. Kenya: The Politics of Participation and Control. Princeton: Princeton University Press, 1974.

17. Bigsten, Arnie. Regional Inequality and Development: A Case Study of Kenya. No. 4. Goteborg, Sweden: National Economic Institution, Goteborg University, 1979.

18. Blaug, Mark. Economics of Education: Selected Readings. New York: Penguin Books, 1968.

19. Bowles, Samuel and Herbert Gintis. Schooling in Capitalist America. ilew York: Basic Books, 1976.

20. Bowman, Mary Jen, et al. Readings in Economics of Education. UNESCO, 1968.

21. Brandt, Willy, et al. North-South: A Programme for Survival. Report of the Independent Commission on International Development Issues. Cambridge: MIT Press, 1980.

22. Brett, E. A. Colonialism and Underdevelopment in East Africa: The Politics of Economic Change 1919-1939. London: Heinemann, 1973.

23. Brownstein, L. Education and Development in Rural Kenya: A Study of Primary School Graduates. New York: Praeger Publishers, 1972.

24. Calpen, Brian. The Village Polytechnic Training Scheme in Kenya: Education for Stagnation or Development! Report Submitted to the Ministry of Labour. Norwich, England: School of Development Studies, University of East Anglia, 1981.

25. Callaway, Archibold. "Unemployment Among African School Leavers." The Journal of Modern African Studies, 1, No. 3 (1963), pp 357-372.

26. Educational Planning and Unemployed Youth. Paris: UNESCO, 1977 .

27. Cardoso, Fernando Henrique. "Industrialization, Dependency and Power in Latin America." Berkeley Journal of Sociology. XVIII, 1972-73, pp 79-95.

28. and Enzo Falletto, eds. Dependency and Development in Latin America. Berkeley: University of California Press, 1979. 
29. Carnoy, Martin. Schooling in a Corporate Society. New York: David McKay Co, Inc., 1972.

30. and Henry M. Levin. The Limits of Educational Reform, New York: Longman, Inc., 1978.

31. Chase-Dunn, Christopher. "The Effects of International Economic Dependence on Development and Inequality: A Cross-National Study." American Sociological Review. No. 40 (1975), pp 720-738.

32. Chege, Michael. Bureaucracy and the Development of African Capitalism in Kenya. Paper Prepared for the Conference on "The African Eourgeoisie: The Development of Capitalism in Nigeria, Kenya, and the Ivory Coast." Dakar, Senegal, 1980.

33. Chenery, Hollins, et al. Redistribution With Growth: Policies to Improve Income Distribution in Developing Countries in the Context of Economic Growth. London: Oxford University Press, 1974.

34. Cline, Williams and N. Sargen. "Performance Criteria and Multilateral Aid Allocation." World Development. June (1975), pp 383-391.

35. Colclough, Christopher and Jacques Hallack. Some Issues in Rural Education: Equity, Efficiency and Employment. Discussion Paper No. 89. Sussex: Institute of Development Studies, University of Sussex, 1976.

36. Coleman, James. Education and Political Development. Princeton: Princeton University Press, 1965.

37. Commonwealth Secretariat. Youth for Development: An African Perspective. Report of a Workshop on National Youth Programmes and National Service held in Accra, Ghana. London, March (1975).

38. Court, David. "The Education System as a Response to Inequaliti in Tanzania and Kenya." The Journal of Modern African Studies. 14 iNo. 4 (1976), pp 661-690.

39. Village Polytechnic Leavers: The Maseno Story. Horking Paper No 72. Nairobi: Institute for Development Studies, University of Nairobi, 1972.

40. and Dharam Ghai, eds. Education, Society and Development: New Perspectives from Kenya. Nairobi: Oxford University Press, 1974.

41. Cowen, Mike and Kabiru Kinyanjui. Some Problems of Capital and Class in Kenya. Occasional Paper No. 29. Nairobi: Institute for Development Studies, University of Nairobi, 1977.

42. Cutright, Phillips. "Inequality: A Cross-national Analysis." American Sociological Review, 32 (1967), pp 562-577. 
43. Diejomaoh et a1. "Unemployment in Nigeria: An Economic Analysis of Scope Trends and Policy Issues." iVigerian Inurnal of Economics and Social Studies. July (1971), 127-160.

44. Dore, Donald, John Humphrey, and Peter Hest. The Basic Arithmetic of Youth Employment: Estimates of School Outputs and Modern Sector Vacancies for Twenty-Five Countries, 1973 and 1980, Working Paper No 9. March (1976). Institute of Development Studies, University of Sussex.

45. Druker, Peter. "The Educational Revolution." in Social Change. Ed. A Etzioni and E Etzioni. New York: Basic Books, 1964.

46. Emmanuel, Arghiri. Unequal Exchange: A Study of Imperialism of Trade. New York: Month7y Review Press, 1972.

47. Evans, Peter. Dependent Development: The Alliance of Multinational, State, and Local Capital in Brazil. Princeton, iv: Princeton University Press, 1979.

48. Fields, Gary. The Education System of Kenya: An Economist's View. Discussion Paper No $103(1971)$. Institute for Development Studies, University of Nairobi.

49. Finley, David. Economic Linkage and Political Dependency in Eastern Europe. Paper Delivered at the Eighth Nationa 7 Convention of American Association for Advancement of Slavic Studies, St Louis, Missouri, October 1976.

50. Ford, R J. "The Village Polytechnic Program in Kenya." International Labour Review. III, No 4, April (1976), 307-320.

51. Fordham, Paul and James R Sheffield. "Continuing Education for Youth and Adults." in Education, Employment, and Rural Development. Ed. James $R$ Sheffield. Nairobi: East Africa Publishing House, 1967, 366-390.

52. Foster, Philip. Education and Social Change in Ghana. Chicago: Chicago University Press, 1965.

53. Frank, Andre G. Capitalism and Underdevelopment in Latin America: Historical Studies of Chile and Brazil. New York: Month7y Review Press, 1967.

54. Galbraith, John K. Economic Development. Cambridge: Harvard University Press, 1964.

55. Galtung, John. "A Structural Theory of Imperialism." Journai of Peace Research. 2 (1971), 81-118.

56. Ginzberg, Eli. Manpower for Development: Perspectives on Five Continents. New York: Praeger PubTishers, 1971. 
57. Godfrey, Martin. Technical and Vocational Training in Kenya and the Harambee Institutes of Technology. Discussion Paper No. 169, Nairobi: Institute for Development Studies, 1973.

58. and Eugene A Godfredsen. Technical and Industrial

Education. Nairobi: Background Paper Prepared for the Ministry of Higher Education, Republic of Kenya; 1979.

59. Hanna, William and Judith Hanna. University Students and African Politics. New York: African Publishing Company, 1975.

60. Hanson, John $W$. Is the School the Enemy of the Farm? The African Experience. Africana Rural Economy Paper No 22, Michigan State University: Department of Agricultural Economics, 1980.

61. Harbison, Frederick and Charles A Meyers. Education, Manpower and Economic Growth: Strategies in Human Resources Development. New York: McGraw-Hi11, 1964.

62. Hawes, $H W R$, et a1. "An African Primary Curriculum Survey-Country Profile: Kenya." University of London: Institute of Education, 1976. (unpublished manuscript)

63. Hazelwood, Arthur and Gerald Hotham. Aid and Inequality in Kenya: British Development Assistance to Kenya. London: Croom Helm and Overseas Development Institute, 1975.

64. Hughes, A J. East Africa. Harmondsworth: Penguin, 1963.

65. Industrial and Commercial Development Corporation. ICDC: Its Role and Activities. Nairobi: ICDC Publications, 1976.

66. Ingraham, Kenneth. A History of East Africa. London: Longmans Press, 1962.

67. Inkles, Alex and D Smith. Becoming Modern: Individual Change in Six Less Developed Countries. Cambridge, Mass: Harvard University Press, 1974.

68. International Bank for Reconstruction and Development. Kenya Into the Second Decade. Report of the World Bank Mission to Kenya. Baltimore and London: The Johns Hopkins University Press, 1975.

69. International Labour Organization. Employment, Income and Equality: A Strategy for Increasing Productive Employment in Kenya. Geneva: ILO, 1973.

70. The Paper Qualification Syndrome (POS) and the Unemployment of School Leavers: A Comparative Sub-regional Study of Four East African Countries--Kenya, Somalia, Tanzania and Zambia. Addis Ababa: ILO Jobs and Skills Programe for Africa (JASPA). January, 1981. 
71. Jenks, Christopher. Inequality: A Reassessment of the Effects of Family and Schooling in America. New York: Basic Books, 1972 .

72. Jolly, Richard, Planning Education for African Development: Economic and Manpower Perspective. Nairobi: East Africa Publishing House, 1969.

73. Jorgensen, $\mathrm{J} \mathrm{J}$. "Multinational Corporations and the Indigenization of the Kenyan Economy," African Studies Review. No. 5 (7975), 429-450.

74. Jorgensen, $\mathrm{N} 0$. ICOC: Its Purpose and Performance. Discussion Paper No 47, University of Nairobi: Institute for Development Studies, 1967.

75. Kaplan, Irving, et al. Area Handbook for Kenya. Washington, DC: American University, Foreign Area Studies, 1976.

76. Kaplinsky, Raphael. Readings on the Multinational Corporation in Kenya. Nairobi: Oxford University Press, 1978.

77. Employment Effects of Multinational Enterprises: A Case Study of Kenya. Working Paper No. 8. University of Sussex: Institute of Development Studies, 1979.

78. _ Inappropriate Products and Techniques in Underdeveloped Countries: The Case of Breakfast Foods in Kenya," Review of African Political Economy. No. 14 (1979), 90-96.

79. An Analys is of ICDC Smal1 Industrial Loan Comitments, 1967-75. Working Paper No. 254. University of Nairobi : Institute for Development Studies, 1976.

80. Karabel, Jerome and A H Ha7sey. Power and Ideology in Education. New York: Oxford University Press, 1977.

81. Keller, Edward J. Education, Manpower, and Development: The Impact of Educational Policy in Kenya. Nairobi: Kenya Literature Bureau, 1980.

82. King, Kenneth. The African Artisan: Education and the Informal Sector in Kenya. New York: Teachers College Press, Columbia University, 1977.

83. "Kenya's Educated Unemployed: A Preliminary Report," Manpower and Unemployment Research in Africa, 7, No. 3 (1974), 45-62.

84. - "Some Notes on Technological Self-Help in Kenya," in Deve Topment Trends in Africa. Edinburgh University: Centre for African Studies, 1972, $175-203$. 
85. Kinyanjui, Kabiru. The Distribution of Educational Resources and Opportunities in Kenya. Discussion Paper No. 208. University of Nairobi: Institute for Development Studies, 1974.

86. - Education and Development in Africa: Theories Strategies, and Practical Implications. Working Paper No. 375. University of Nairobi: Institute for Development Studies, 1980.

87 . - Regional and Class Inequalities in Provision of Primary Education in Kenya, Qualifying Paper. Cambridge: Harvard Graduate School of Education, December 1977.

88. - "Education, Training and Employment of Secondary School Leavers in Kenya," Manpower and Unemployment Research in Africa. 6, No. 2 (March 1973), 79-97.

89. - Secondary School Strikes: The Art of Blaming the Victim. Discussion Paper No. 243. University of Nairobi: Institute for Development Studies, 1976.

90. Education and Inequality in Kenya: Some Research Experience and Issues. Working Paper No. 373. University of Nairobi: Institute for Development Studies, 1981.

21. - Education for Rural Development in Kenya: A Critical iNote. Discussion Paper No. 264. University of Nairobi: Institute for Development Studies, 1979.

92. Kipkorir, Ben and Sidney B Westley. Nonformal Education in Kenya. Discussion Paper No. 211. University of Nairobi: Institute for Development Studies, 1974.

93. "Kenya: Development and Coordination of Nonformal Programs." In Education for Rural Development: Case Studies for Planners. Ed. Ahmed Manzoor and Philip Coombs. New York: Praeger Publishers, 1975. pp 175-215.

94. Kitching, Gavin. Class and Economic Change in Kenya: The Making of An African Petite Bourgeoisie, 1905-1970. New Haven: Yale University Press, 1980.

95. Klause, Hans. Parastatals in Kenya: Analysis of Their Conditions and Methods for an Improved Performance. Working Paper No. 370. University of Nairobi: Institute for Development Studies, 1979.

96. Koinange, Mbiyu. The People of Kenya Speak for Themselves. Detroit: Kenya Publications Fund, 1955. 
97. Lancaster, K J. "A New Approach to Consumer Theory," Journal of Political Economy, LXXXIV, No 2, April (1966), 132-157.

98. "Change and Innovation in the Technology of Consumption," American Economic Review. 56, No. 2 (1966), 14-23.

99. Langdon, Steven. Multinational Corporations in the Political Economy of Kenya. University of Sussex, 1976. (unpublished PhD dissertation).

100.

Political Economy." In Readings on the Multinational Corporation in Kenya. By Raphael Kaplinsky. Nairobi: Oxford University Press, 1978. pp 134-200.

101. - Multinational Corporations in the Political Economy of Kenya. New York: St Martins Press, 1981.

102. - Industry and Capitalism in Kenya: Contributions to a Debate. Paper Prepared for the Conference on the African Bourgeoisie, Dakar, Senegal, 1980.

103. Lewis, L J. The Phelps-Stokes Report on Education in Africa. London: Oxford University Press, 1962.

104. - Educational Policy and Practice in British Tropical Areas. London: Thomas NeTson and Sons, Ltd, 1954.

105. Leys, Colin. Underdevelopment in Kenya: The Political Economy of Neocolonialism. Berkeley: University of California Press, 1974.

106. - "Underdevelopment and Dependency Notes," Journal of Contemporary Asia. 7, No. 1 (1977), 92-107.

107. Livingstone, Ian. Rural Development, Employment and Income in Kenya. Addis Ababa: International Labour Office, Jobs and SkitTs Programme for Africa (JASPA), 1981.

108. Lugard, Lord. The Dual Mandate in British Tropical Africa. London: Blackwood, 1922 .

109. Mackie, William L. Educating for Agriculture: The Kenyan Experience. Los Angeles: University of California Press, 1971. (unpublished PhD dissertation).

110. Marris, Peter and Tony Somerset. African Businessmen: A Study of Entrepreneurship and Development in Kenya. London: RoutTedge and Kagan Paul, 1971. 
111. Morrison, C. Income Distribution in Kenya. Washington, DC: World Bank, 1973.

112. Mutua, Rosalind. Development of Education in Kenya: Some Administrative Aspects 1846-1963. Nairobi: East African Literature Bureau, 1975.

113. Mwaniki, N. Public Policy and Political Development: The Implementation of the Africanization Policy Through ICDC's Small Industrial Loan Scheme, 1967-1973. Working Paper No. 295. University of Nairobi: Institute for Development Studies, 1977.

174. National Christian Council of Kenya. Who Controls Industry in Kenya? Nairobi: East African Publishing House, 1968.

115. - After School What? A Report on Further Education, NCCK, 1966.

116. Needleman, L and S La11, R Lacy, and J Seagrave. Balance-of-Payments Effects of Private Foreign Investment: Case Studies of Jamaica and Kenya. UNCTAD Document TD/B/C.3/79 Add.2,21. May (1970).

117. Njojo, Apol10. "The Kenyan Peasantry: A Reassessment," Review of African Political Economy. No. 20 (1981), 27-40.

118. Nkinyangi, John A. Socio-economic Determinants of Repetition and Early School withdrawal at the Primary Level and Their Implication for Educational Planning in Kenya. Working Paper 325. University of Nairobi: Institute for Development Studies, 1977.

119. Norcliff, G B. Towards a Locational Policy for Manufacturing Industry in Kenya. Ministry of Finance and Planning, 1977. (mimeo)

120. Norwegian Agency for International Development. The Kenyan Village Polyteshnic Programme. Report of the Evaluation Mission, 1974.

121. Nyangira, N. Relative Modernization and Public Resource Allocation in Kenya. Nairobi: East African Literature Bureau, 1975.

122. Okumu, John and Joel D Barkan. Politics and Public Policy in Kenya and Tanzania. New York: Praeger Publishers, 1979.

123. (with) Gordon Hyden and Robert Jackson. Development Administration: The Kenyan Experience. Nairobi: Oxford University Press, 1970. 
124. Oyugi, W 0. "Government and Public Enterprise: Some Observations on Kenya," University of Nairobi: Department of Government, 1980. (mimeo)

125. Pack, Howard. Employment and Productivity in Kenyan Manufacturing. Discussion Paper No. 149. University of Nairobi: Institute for Development Studies, 1972.

126. "The Substitution of Labour for Capital in Kenyan Manufacturing." In Papers on the Kenyan Economy: Performance Problems and Policies. Ed. Tonny Killick. Nairobi: Heinemann Educational Books, Ltd, 1981. pp 254-265.

127. Phelps, M G. "Protection of Industry in Kenya." In Development Trends in Kenya. Preceedings of a Conference at the Centre of African Studies, Edinburgh University, 1972.

128. and $B$ Wasow. Measuring Protection and its Effects in Kenya. Working Paper No. 37. University of Nairobi: Institute for Development Studies, 1972.

129. Raju, Beulah, M. Education in Kenya: Problems and Perspectives in Educational PTanning and Administration. London: Heinemann, 1973.

130. Ranger, Terence. "African Attempts to Control Education in East and Central Africa, 1900-1939," Past and Present. No. 32. December (1965), 57-85.

131. Ray, David. "The Dependency Mode1 of Latin American Underdeveropment: Three Basic Fallacies," Journal of Inter-American Studies and World Affairs. XV. February (7973), 4-20.

132. Rempe1, Henry. Labor Migration into Urban Centers and Urban Unemployment. University of Wisconsin, 1971. (unpublished PhD dissertation)

133. Richardson, H W. "An Urban Development Strategy for Kenya," Journal of Developing Areas. 15, No. 1. October (1980), 97-118.

134. Rodney, Walter. How Europe Underdeveloped Africa. Washington, DC: Howard University Press, T974.

135. Roseberg, Carl and John Nottingham. The Myth of Mau Mau: Nationalism in Kenya. New York: Praeger Publishers, 1966.

136. Rostow, Walt W. Stages of Economic Growth: A Non-communist Manifesto. London: Cambridge University Press, 1960.

137. Rothchild, Donald and Robert L Curry, Scarcity, Choice and Public Policy in Middle Africa. Berkeley: University of California Press, 1978. 
138. Santos, Theotonio dos. "The Structure of Dependence." In The Political Economy of Development and Underdevelopment. Ed. Charles K Wilber. New York: Random House, 1973. pp 109-118.

139. Schultz, Theodore W. "Investment in Human Capital," American Economic Review. 51. March (1961), 1-17.

140. Sheffield, James R. Education in Kenya: An Historical Study. New York: Teachers College Press, Columbia University, 1973.

141. Education, Employment and Rural Development. Nairobi: East African Publishing House, 1967.

142. Sifuna, D N. Short Essays on Education in Kenya. Nairobi: East African Literature Bureau, 1980.

143. Somerset, Anthony. Who Goes to Secondary School? Efficiency, Equity and Relevance in Secondary School Selection. Discussion Paper No. 184. University of Nairobi: Institute for Development Studies, 1973.

144. Stabler, Ernest. "Kenya and Tanzania: Strategies and Realities in Education and Development," Africa Affairs (1977), 33-55.

145. Stewart, Francis. Technology and Development. London: Macmillan, 1977.

146. . "The Tripartite Agreements in Kenya." In Essays on Employment in Kenya. Eds. Dharam Ghai and Martin Godfrey. Nairobi: Kenya Literature Bureau, 1979. pp 155-181.

147. . "Choice of Technology in Developing Countries," Journal of Development Studies, 9, No. 1. October (1972) 99-121.

148. Sunkel, Osvaldo. "Big Business and Dependencia," Foreign Affairs. 5, No. 3. April (1972), 517-534.

149. Swainson, Nicola. The Development of Corporate Capitalism in Kenya, 1917-1977. Berkeley: University of California Press, 1980.

150. Todaro, Michael and John R Harris. "Migration, Unemployment and Development: A Two Sector Analysis," The American Economic Review. LX. March (1970), 126-142.

151. Turnham, David. The Employment Problem in Less Developed Countries: A Review of Evidence. Paris: The Organization for Economic Cooperation and Development (OECD), 1971. 
152. U S Government, Department of Commerce. Marketing in Kenya. Washington, DC: International Marketing Information Series, International Trade Administration, Overseas Business Rept, OBR 82-09, May 1982.

153. - Department of Commerce. Foreign Economic Trends and Their Implications for the United States--Focus on Kenya. Washington, DC: International Trade Administration, Overseas Business Reports, FET 82-011, February 1982.

154. - U S Policy Towards International Investment. Hearings of Subcomittee on International Economic Policy, Foreign Relations Committee of U S Senate, 97th Congress, July 30 , Sept 28, Oct 28 (1981), Sec 149-154, 412-417.

155. van Zwanenberg, Roger. Colonialism and Labour In Kenya: 1919-1939. Nairobi: East African Literature Bureau, 1975.

156. (with) Ann King. An Economic History of Kenya and Uganda, 1800-1970. Nairobi: East African Literature Bureau, 1975.

157. Wangia, C W. Brief Comments on the Study Report on the Paper Qualification Syndrome (PQS) and the Unemployment of School Leavers: The Kenya Case. Ministry of Labor, Division of Manpower Planning and Development. July 1981.

158. Wanjala, Edward. Picking up the Pieces--The Village Polytechnic Movement in Kenya. National Christian Council of Kenya. Aug 1981.

159. Wanjohi, Gatheru N. The Politics of Foreign Aid in Kenya, 19631977. University of Nairobi, 1982. (Unpublished PhD dissertation).

160. Warren, Bill. "Imperialism and Capitalist Industrialization," The New Left Review. $81 \quad(1973)=3-46$.

161. Wasserman, Gary. Politics of Decolonization: Kenya, Europeans and the Land Issue, 1960-65. London: Cambridge University Press, 1973.

162. Continuity and Counter-Insurgency: The Role of Land Reform in Decolonizing Kenya, 1962-70," Canadian Journal of African Studies, 7, No. 1 (1973), 133-148.

163. Weeks, John. "Wage Policy and the Colonial Legacy--A Comparative Study," The Journal of Modern African Studies. 9, No. 3 (1971), 367-71. 
164. - "Employment, Growth and Foreign Domination in Underdeveloped Countries, "Review of Radical Political Economics. 4, No. 1 (1972), 58-68.

165. Weeks, Sheldon. Divergence in Educational Development: The Case of Kenya and Uganda. New York: Teachers College Press, Columbia University, 1967.

166. White, Charles R. Political Change and Public Policy in Latin America. The University of Arizona, 1977. (Unpublished PhD dissertation).

167. Whitelaw, WE. The Urban Household Survey. Discussion Paper No. 116. University of Nairobi: Institute for Development Studies, 1971.

168. Wolff, R D. The Economics of Colonialism: Britain and Kenya, 1919-1939. New Haven: Yale University Press, 1974.

169. World Bank. Kenya and the World Bank. Basic Data Prepared by the World Bank Resident Representative in Kenya, 1981. (mimeo)

COLONIAL GOVERNMENT DOCUMENTS

1. Kenya Colony and Protectorate. African Education in Kenya. Nairobi: Government Printer, 1949. (The Beecher Report).

2. A Plan to Intensify the Development of African Agriculture in Kenya. Nairobi: Government Printer, 1954. (Swynnerton Plan).

3. A Ten-Year Plan for the Development of African Education. Nairobi: Government Printer, 1948. (Ten-YearPTan).

4. Great Britain, Colonial Office Advisory Committee for Education in the Colonies. Education for Citizenship. Col. No. 216. London: HMSO, 1948.

\section{KENYA GOVERNMENT DOCUMENTS}

1. Republic of Kenya. African Socialism and its Application to Planning in Kenya. Nairobi: Government Printer, 1965.

2. Development Plan 1964-70. Nairobi: Government Printer, T964. 
3. Development Plan 1970-74. Nairobi: Government Printer, 1969 .

4. Development Plan 1974-78. Nairobi: Government Printer, 1973.

5.. Development Plan 1979-83. Nairobi: Government Printer, T978.

6. Ministry of Economic Planning and Development. Economic Surveys, 1965-81. Nairobi: Government Printer.

7. Ministry of Economic Planning and Development. Statistical Abstracts, 1965-80. Nairobi: Government Printer.

8. Ministry of Education. Annual Reports, 1963-78. Nairobi: Government Printer.

9. Ministry of Labor. Annual Reports 1964 and 1965. Nairobi: Government Printer.

10. Ministry of Economic Planning and Development. High-Level Manpower Requirements and Resources in Kenya 1964-70. Nairobi: Government Printer, 1965.

11. Ministry of Commerce and Industry. A Guide to Industrial Investment in Kenya. Nairobi: Government Printer, 1972.

12. Report of the Education Commission: Part I. Nairobi: Government Printer, 1964. (Ominde Report).

13. Report of the Education Commission: Part II.' Nairobi: Government Printer, 1975. (Ominde Report).

14. Report of the Commission of Inquiry, 1970-71: Public Service Structure and Remuneration Commission. Nairobi : Government Printer, 1971. (Ndegwa Commission Report).

15. Report of the National Committee on Educational Objectives and Policies. Nairobi: Government Printer, 1976.

16. University Education in Kenya: First Report of the 1980-83 University Grants Committee. Nairobi: Government Printer, 1981 .

17. Review of Statutory Boards. Report and Recommendations of the Committee Appointed by His Excellency The President. Nairobi: Government Printer, 1979. 
18. The Foreign Investment Protection Act of 1964. Nairobi: Government Printer, 1964.

19. Budget Speech for the Fiscal Year 1974/75. Nairobi: Government Printer, 1975.

\section{PERSONAL INTERVIEWS}
1. $(1 / 7 / 82)$
14. $(2 / 3 / 82)$
2. $(1 / 11 / 82)$
15. $(2 / 5 / 82)$
3. $(1 / 13 / 82)$
16. $(2 / 8 / 82)$
4. $(1 / 14 / 82 a)$
17. $(2 / 9 / 82 a)$
5. $(1 / 14 / 82 b)$
18. $(2 / 9 / 82 b)$
6. $(1 / 15 / 82)$
19. $(2 / 10 / 82)$
7. $(1 / 16 / 82)$
20. (2/11/82a)
8. $(1 / 19 / 82)$
21. $(2 / 11 / 82 b)$
9. $(1 / 21 / 82 a)$
22. $(2 / 12 / 82)$
10. (1/21/82b)
23. $(2 / 13 / 82)$
11. $(1 / 30 / 82)$
24. $(2 / 16 / 82)$
12. (2/1/82a)
25. $(2 / 17 / 82)$
13. $(2 / 1 / 82 b)$ 




Source: (GR133) Compiled from Central Bureau of Statistics 


\section{APPENDIX B \\ ICDC SUBSIDIARIES AND ASSOCIATED COMPANIES \\ June 30,1979}

\begin{tabular}{|c|c|c|}
\hline $\begin{array}{l}\text { Wholly Owned } \\
\text { Subsidiaries }\end{array}$ & $\begin{array}{l}\text { ICDC share- } \\
\text { holding }\end{array}$ & Products/Activities \\
\hline $\begin{array}{l}\text { Kenya Nat'l Trading } \\
\text { Corp (KNTC) }\end{array}$ & $100 \%$ & $\begin{array}{l}\text { Kenyanization of Distribution of } \\
\text { Trade and Export House }\end{array}$ \\
\hline Keyna Film Corp, Ltd & $100 \%$ & $\begin{array}{l}\text { Importation and distribution of } \\
\text { cinema filem, owns \& runs cinema }\end{array}$ \\
\hline Kenya Nat' 1 Properties & $100 \%$ & Develop commercial properties \\
\hline Africa Diatomite Ltd & $100 \%$ & $\begin{array}{l}\text { Production of calcined and un- } \\
\text { calcined diatomite }\end{array}$ \\
\hline Kenya Fishing Indus & $100 \%$ & $\begin{array}{l}\text { Inshore and deep sea fishing, } \\
\text { cold storage }\end{array}$ \\
\hline Uchumi House & $100 \%$ & Large grocery stores \\
\hline \multicolumn{3}{|l|}{ Other Subsidiaries: } \\
\hline $\begin{array}{l}\text { Kentaco Transport Co, } \\
\text { Ltd }\end{array}$ & $97 \%$ & Long distance hauling and taxi svo \\
\hline $\begin{array}{l}\text { Kenya Wine Agencies, } \\
\text { Ltd }\end{array}$ & $75 \%$ & Importation/distribution of wine \\
\hline $\begin{array}{l}\text { Ceramic Industries, } \\
\text { Ltd }\end{array}$ & $51 \%$ & $\begin{array}{l}\text { Production of crockery, chemical } \\
\text { resistant floor tiles }\end{array}$ \\
\hline $\begin{array}{l}\text { Genera] Motors Kenya, } \\
\text { Ltd }\end{array}$ & $57 \%$ & Assembiy of medium size trucks \\
\hline Minet-ICDC, Ltd & $51 \%$ & Insurance broking \\
\hline $\begin{array}{l}\text { East Africa Fine } \\
\text { Spinners }\end{array}$ & $71 \%$ & Manufacturing of sewing thread \\
\hline
\end{tabular}


Associated Companies:

\begin{tabular}{|c|c|c|}
\hline Kenya Cashewnuts, Ltd & $33 \%$ & Cashewnuts processing \\
\hline Associated Battery Manuf & $20 \%$ & Automobile batteries \\
\hline $\begin{array}{l}\text { Africa Radio Manuf, } \\
\quad \text { Ltd }\end{array}$ & $34 \%$ & $\begin{array}{l}\text { Assembly of radio, tv, tape re- } \\
\text { corders }\end{array}$ \\
\hline $\begin{array}{l}\text { Kenya Engineering } \\
\text { Industry }\end{array}$ & $50 \%$ & Produce clocks, shovels, etc \\
\hline ESA Book-shop, Ltd & $49 \%$ & $\begin{array}{l}\text { Distribution of books and lab } \\
\text { equipment }\end{array}$ \\
\hline Kenya Fishnet, Ltd & $43 \%$ & Manufacture of fishnets \\
\hline Brollo Kenya, Ltd & $40 \%$ & $\begin{array}{l}\text { Steel sheet rolling and cutting; } \\
\text { fabrication of pipes, angles }\end{array}$ \\
\hline $\begin{array}{l}\text { NAS Airport Service, } \\
\text { Ltd }\end{array}$ & $27 \%$ & Catering of airlines \\
\hline $\begin{array}{l}\text { East Africa Clothing } \\
\text { Factory }\end{array}$ & $38 \%$ & Manufacture of industrial uniforms \\
\hline Union Carbide, Ltd & $35 \%$ & Manufacture of dry cell batteries \\
\hline $\begin{array}{l}\text { Rift Valley Textile, } \\
\text { Ltd }\end{array}$ & $39 \%$ & $\begin{array}{l}\text { Manufacture of textiles and } \\
\text { fabrics }\end{array}$ \\
\hline $\begin{array}{l}\text { Kenya Industrial } \\
\text { Plastics }\end{array}$ & $33 \%$ & $\begin{array}{l}\text { Manufacture of melamine wares, } \\
\text { dinner sets, toilet seats }\end{array}$ \\
\hline $\begin{array}{l}\text { East African Indus- } \\
\text { tries, Ltd }\end{array}$ & $34 \%$ & Produces soap, detergent, fats \\
\hline $\begin{array}{l}\text { Kulia Iivestment, } \\
\text { Ltd }\end{array}$ & $4 \%$ & $\begin{array}{l}\text { Operates tourist hotels in Kenya } \\
\text { Seychelles }\end{array}$ \\
\hline Pan Africa Paper Mills & $6 \%$ & $\begin{array}{l}\text { Produces over } 45,000 \text { tons of pulp } \\
\text { and paper per year }\end{array}$ \\
\hline ICDC Investment Co & $19 \%$ & $\begin{array}{l}\text { An investment company assisting } \\
\text { small investors to share directly } \\
\text { in the profits of well established } \\
\text { companies in Kenya }\end{array}$ \\
\hline Nakulines, Ltd & $6 \%$ & Clearing and forwarding agent \\
\hline
\end{tabular}




\begin{tabular}{|c|c|c|}
\hline $\begin{array}{l}\text { Raymond Woolen Mills, } \\
\text { Ltd }\end{array}$ & $14 \%$ & $\begin{array}{l}\text { Woolen/worsted yarns, suiting } \\
\text { fabrics }\end{array}$ \\
\hline Metal Box (K), Ltd & $17 \%$ & $\begin{array}{l}\text { Printed metal containers, plas- } \\
\text { tic pipes, domestic appliances }\end{array}$ \\
\hline Firestone $(E A)$, Ltd & $20 \%$ & Produce tires and tubes \\
\hline $\begin{array}{l}\text { Nakuru Chrone Tan- } \\
\text { ning, Ltd }\end{array}$ & $20 \%$ & Tanning of goat skins \\
\hline $\begin{array}{l}\text { Sokoro Fiber Boards, } \\
\text { Ltd }\end{array}$ & $26 \%$ & $\begin{array}{l}\text { Produce and export soft boards } \\
\text { and wallboards }\end{array}$ \\
\hline Elson Plastics, Ltd & $28 \%$ & $\begin{array}{l}\text { Produce rigid PCV pipes, plas- } \\
\text { tic bottles and containers }\end{array}$ \\
\hline $\begin{array}{l}\text { Mount Kenya Bottlers, } \\
\text { Ltd }\end{array}$ & $42 \%$ & Bottle soft drinks \\
\hline $\begin{array}{l}\text { Rift Valley Bottlers, } \\
\text { Ltd }\end{array}$ & $43 \%$ & Bottle soft drinks \\
\hline $\begin{array}{l}\text { Polysynthetics EA, } \\
\text { Ltd }\end{array}$ & $30 \%$ & $\begin{array}{l}\text { Produce synthetic resin for } \\
\text { paint, paper, and textile } \\
\text { industries }\end{array}$ \\
\hline Seracoating, Ltd & $40 \%$ & $\begin{array}{l}\text { Adhesive and wide range } P C V \\
\text { coated fabrics and unsupported } \\
\text { films }\end{array}$ \\
\hline $\begin{array}{l}\text { Pan-African Vege- } \\
\text { tables, Ltd }\end{array}$ & $39 \%$ & Vegetable dehydration for export \\
\hline $\begin{array}{l}\text { Wananchi Sawmills, } \\
\text { Ltd }\end{array}$ & $45 \%$ & Sawmiling and export timber \\
\hline $\begin{array}{l}\text { Infusions Kenya, } \\
\text { Ltd }\end{array}$ & $22 \%$ & Medical infusions \\
\hline $\begin{array}{l}\text { Dawa Pharmaceutical, } \\
\text { Ltd }\end{array}$ & $33 \%$ & Pharmaceuticals \\
\hline $\begin{array}{l}\text { Kenya Textile Mills, } \\
\text { Ltd }\end{array}$ & $55 \%$ & Manufacture of textiles \\
\hline Yuken Textiles, Ltd & $33 \%$ & $\begin{array}{l}\text { High quality shirts, children's } \\
\text { wear }\end{array}$ \\
\hline $\begin{array}{l}\text { African Synthetic } \\
\text { Fibers }\end{array}$ & $49 \%$ & $\begin{array}{l}\text { Polyester texturized filament } \\
\text { yarns }\end{array}$ \\
\hline
\end{tabular}




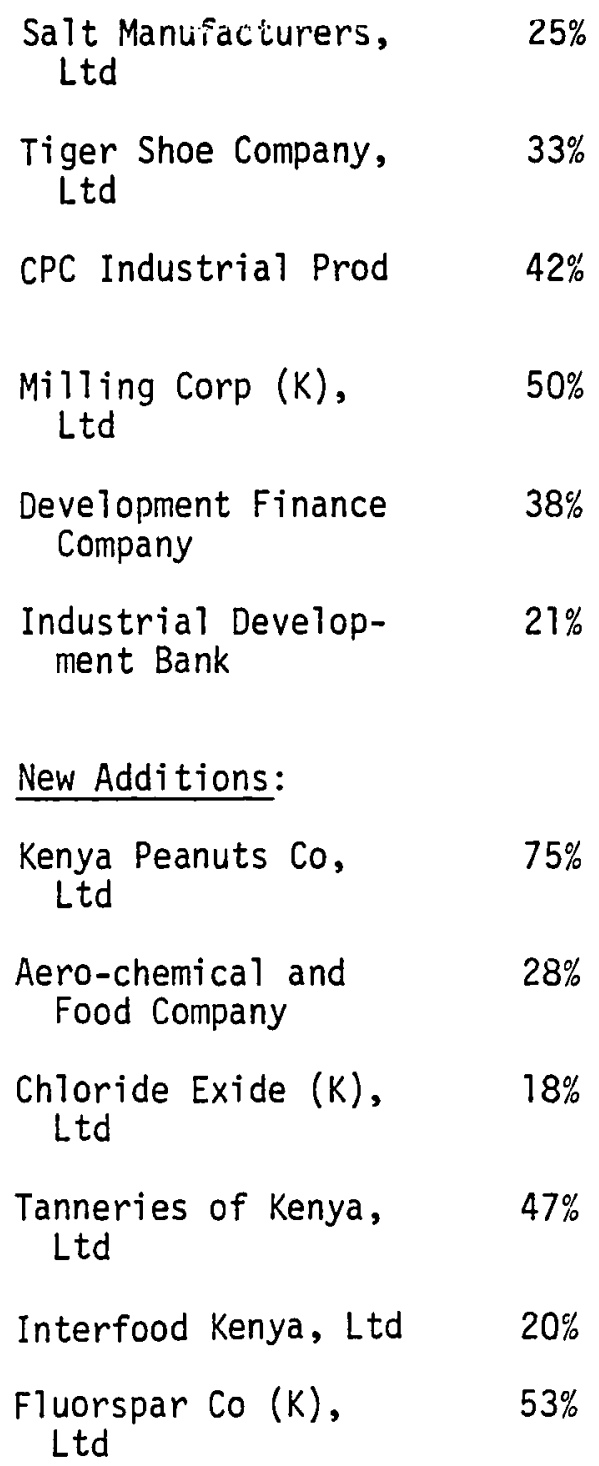


APPENDIX C

EDUCATIONALL AND ECONOMIC POLICY INTERVIEW

Date

Code Number

Name

Position

\section{SECTION I}

1. In what ways is education being put to use in Kenya? In other words, in what ways does education contribute to the development of Kenya?

2. How do you evaluate Kenya's primary and secondary educational system? If you believe some changes need to be made, what are those changes?

3. Unemployment in Kenya is a major concern of government policy. Would you identify some of the underlying causes of urban unemployment?

4. The growing numbers of the unemployed are school leavers. Would you identify some of the underlying causes of unemployment among the school 1eavers? 
5. Are rising levels of educated unemployment a temporary or chronic phenomenon? Would you consider that provision of technical education will increase employment opportunities for school leavers?

6. What suggestions would you make for improving the links between education and the labor market? Are there any questions I should be asking you that are relevant to this issue?

\section{SECTION II}

7. What has been the influence of external economic assistance to Kenya's developmental efforts? Conversely, in what ways have Kenya's policies influenced the inflow of aid and investment into the country?

8. What sort of working relations do you have with the government of Kenya? If there were a particular issue you wished to influence government policy on, what channels would you use to approach them? Would you have any informal contacts in government that you could use to make your influence felt?

9. How much of the initial investment capital was raised by your firm (or parent company) and how much was raised through loan or credit from local Kenyan sources?

10. What percentage of your machines and equipment is imported directly and from which countries?

11. What producer materials/items (raw materials) do you import and which countries are the main suppliers? 
12. What are the advantages and disadvantages of going into a joint venture activity with the government of Kenya. What assistance do you receive from such government parastatals as the DFCK and ICDC?

13. If you have a parastatal partner, in what ways does the parastatal help your business operations in Kenya? Be specific. 